\title{
Editoras/es
}

Marta Sara Francisco

Rodríguez

Pérez

Campos

Castro

Seijo

Freire

Prólogo: Francisco Campos-Freire, Miguel Túñez-López y

Marta Rodríguez-Castro

\section{La TV Pública en Europa: Innovación, Retos y Tendencias}

Cuadernos Artesanos de Comunicación / 146

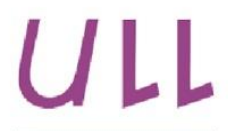

Universidad de La Laguna
Universitat d'Alacant Universidad de Alicante
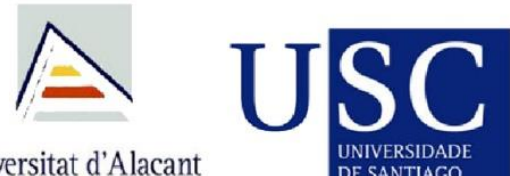

UNIVRSIDA DE COMPOSTELA

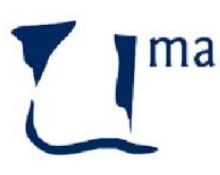

UNIVERSIDAD UE MALAGA

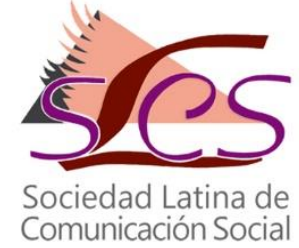




\section{Cuadernos Artesanos de Comunicación}

Coordinador editorial: José Manuel de Pablos - jpablos@ull.edu.es

Comité Científico

Presidencia: José Luis Piñuel Raigada (UCM)

Secretaría: Milena Trenta (ULL)

- Núria Almiron (Universidad Pompeu Fabra, UPF)

- José Cisneros (Benemérita Universidad Autónoma de Puebla, BUAP)

- Bernardo Díaz Nosty (Universidad de Málaga, UMA)

- Carlos Elías (Universidad Carlos III de Madrid, UC3M)

- Paulina B. Emanuelli (Universidad Nacional de Córdoba, UNC)

- José Luis González Esteban (Universitat Miguel Hernández de Elche, UMH)

- Marisa Humanes (Universidad Rey Juan Carlos, URJC)

- Juan José Igartua (Universidad de Salamanca, USAL)

- Xosé López (Universidad de Santiago de Compostela)

- Maricela López-Ornelas (Universidad Autónoma de Baja California, AUBC)

- Javier Marzal (Universidad Jaume I, UJI)

- José Antonio Meyer (Benemérita Universidad Autónoma de Puebla, BUAP)

- Ramón Reig (Universidad de Sevilla, US)

- Miquel Rodrigo Alsina (Universidad Pompeu Fabra, UPF)

- Xosé Soengas (Universidad de Santiago de Compostela)

- José Luis Terrón (Universidad Autónoma de Barcelona, UAB)

- Victoria Tur (Universidad de Alicante, UA)

- Miguel Vicente (Universidad de Valladolid, UVA)

- Ramón Zallo (Universidad del País Vasco, UPV-EHU)

* Queda expresamente autorizada la reproducción total o parcial de los textos publicados en este libro, en cualquier formato o soporte imaginables, salvo por explícita voluntad en contra del autor o autora o en caso de ediciones con ánimo de lucro. Las publicaciones donde se incluyan textos de esta publicación serán ediciones no comerciales y han de estar igualmente acogidas a Creative Commons. Harán constar esta licencia y el carácter no venal de la publicación.

Este libro y cada uno de los capítulos que contiene (en su caso), así como las

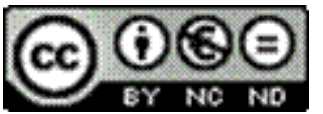
imágenes incluidas, si no se indica lo contrario, se encuentran bajo una Licencia Creative Commons Atribución-No Comercial-Sin Derivadas 3.0 Unported. Puede ver una copia de esta licencia en http://creativecommons.org/licenses/by-nc-nd/3.0/ Esto significa que Ud. es libre de reproducir y distribuir esta obra, siempre que cite la autoría, que no se use con fines comerciales o lucrativos y que no haga ninguna obra derivada. $\mathrm{Si}$ quiere hacer alguna de las cosas que aparecen como no permitidas, contacte con los coordinadores del libro o con el autor del capítulo correspondiente.

* La responsabilidad de cada texto es de su autor o autora. 


\section{Editoras/es}

Marta Rodríguez-Castro/Sara Pérez-Seijo/

Francisco Campos-Freire

Prólogo: Francisco Campos-Freire/Miguel Túñez-López /

Marta Rodríguez-Castro

\section{La TV Pública en Europa: Innovación, Retos y Tendencias}

Cuadernos Artesanos de Comunicación / 146

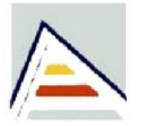

Universitat d'Alacant Universidad de Alicante
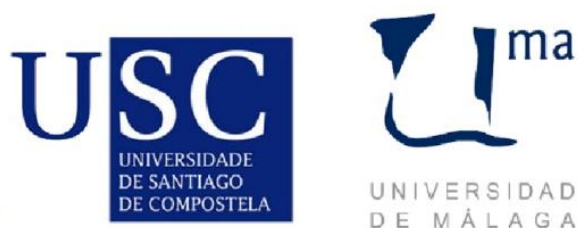

UNIVERSIDAD DE MÁLAGA

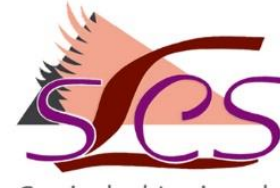

Sociedad Latina de Comunicación Social 


\section{CAC 146 - La TV Pública en Europa: Innovación, Retos y}

\section{Tendencias}

Editoras/es del CAC 146 Marta Rodríguez-Castro, Sara Pérez-Seijo y Francisco Campos-Freire

| Precio social: 9,40€ | Precio en librería: $12,20 €$ |

Editores: Javier Herrero y Milena Trenta

Diseño: F. Drago

Ilustración de portada: Fragmento del cuadro "Mujer de Fuenteventura", de Vale (Bolonia).

Imprime y distribuye: F. Drago. Andocopias S. L.

c/ La Hornera, 41. La Laguna. Tenerife.

Teléfono: 922250554 | fotocopiasdrago@elefonica.net

Edita: Sociedad Latina de Comunicación Social - edición no venal

- La Laguna (Tenerife), 2017 - Creative Commons

http://www.revistalatinacs.org/14SLCS/portada2014.html

Descargar en pdf:

http://www.cuadernosartesanos.org/\#146

Protocolo de envío de manuscritos con destino a CAC: (la colección que corresponda)

http://www.cuadernosartesanos.org/protocolo.html

ISBN - 978-84-17314-02-6

DL: TF 902-2018

DOI: $10.4185 / \operatorname{cac} 146$ 


\section{Índice}

\section{Prólogo}

Retos 2020-30 para el servicio audiovisual público

Francisco Campos-Freire, Miguel Túnez-Lópezy Marta Rodriguez-Castro..

1. Análisis de las narrativas inmersivas en vídeo $360^{\circ}$ publicadas por el Lab RTVE.es (2015-2017)

María José Benitez de Gracia y Sara Pérez-Seijo

2. Reflexiones en torno a los desafíos regulatorios de la nueva Directiva de Servicios de Comunicación Audiovisual

Laura Caballero Trenado.

3. Transparencia y gestión en las televisiones públicas del Suroeste europeo

Carmen del Rocío Monedero Morales y Silvia Olmedo Salar.

4. Cobertura informativa de procesos electorales: innovación y oportunidad de un servicio público esencial

Fermin Galindo Arrazy Juan Carlos Regueira Rey.

5. Transparencia y facilidad de acceso en los portales web de las televisiones públicas autonómicas

Ana María López. Cepeda, Belén Galletero Campos e Inmaculada Teruel Carrión

6. E1 uso estratégico del audiovisual en el manejo de la información global-local. Caso de estudio de la disidencia en la frontera Colombo-Ecuatoriana

Kruzkaya Ordónezy Catalina Mier

7. La analogía del ecosistema televisivo español e italiano: TVE vs. RAI

Javier Pérez Sánchez.

8. Políticas y estrategias de transparencia para las radiotelevisiones públicas europeas 
9. Presencia de las televisiones públicas españolas en la red social Menéame

Begoña Zalbidea, Idoia Camacho, Jose Mari Pastory Santi Urrutia

10. Análisis económico comparativo vertical de las empresas privadas televisivas nacionales de Ecuador: Teleamazonas - Ecuavisa

Ana Cecilia Vaca-Tapia, Francklin Iván Rivas-Echeverria y Johnny Alejandro Aragón-Puetate...........................................................................................207

Los autores y las autoras .227

El contenido de este libro ha sido sometido a un proceso de revisión de doble ciego por pares, semejante al sistema de revisión de un artículo científico para un journal. 


\title{
La TV pública en Europa: Innovación, Retos y Tendencias
}

\author{
Editoras/es: Marta Rodríguez-Castro, Sara Pérez-Seijo \\ y Francisco Campos-Freire
}

\section{Resumen}

El presente Cuaderno Artesano de Comunicación (CAC) recoge 10 trabajos presentados en el I Simposio Internacional de la Revista Latina de Comunicación Social, celebrado en Santiago de Compostela en septiembre de 2018. Con este volumen se cierra la trilogía que tenía como objetivo proporcionar un espacio para el análisis y la reflexión sobre el servicio audiovisual público (SAP) y la innovación en comunicación.

Los diez capítulos que conforman este CAC, seleccionados mediante una revisión de calidad basada en el sistema de doble ciego, abordan cuestiones fundamentales para el futuro del SAP europeo: las estrategias de transparencia, el futuro regulatorio que plantea la nueva Directiva de Servicios de Comunicación Audiovisual, el impacto de las plataformas digitales sobre los medios públicos, experiencias con nuevas narrativas inmersivas, las coberturas informativas de acontecimientos de naturaleza diversa o los retos vinculados a la financiación. Las aportaciones de investigadores procedentes de hasta 10 universidades ha permitido elaborar este último volumen de la trilogía en el que se detallan los principales retos y tendencias a los que se enfrenta el SAP europeo.

Palabras clave: televisiones públicas europeas, innovación en comunicación, regulación, transparencia, plataformas digitales.

\section{Forma de citar este libro}

Rodríguez-Castro, M., Pérez-Seijo, S. y Campos-Freire, F. (Eds.) (2018). La TV pública en Europa: Innovación, Retos y Tendencias. Cuadernos Artesanos de Comunicación, cac 146. La Laguna (Tenerife): Latina. DOI: $10.4185 /$ cac146. 



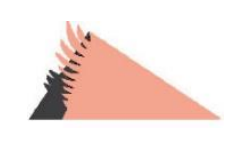

\section{Prólogo}

\section{Retos 2020-30 para el servicio audiovisual público}

El servicio audiovisual público se enfrenta en los próximos años, en la década de 2020 a 2030, a importantes retos de transformación para adaptarse al nuevo ecosistema de medios de comunicación y a los cambios tecnológicos, económicos y sociales de la era de Internet. Su legitimidad está presionada y afectada por esos retos, pero su existencia sigue siendo tan necesaria como lo fue en sus orígenes porque sus valores fundacionales también son imprescindibles en la sociedad de Internet. Como contextualización previa a los 11 trabajos que recogemos en este volumen, enunciamos a continuación diez de esos importantes retos a los que se enfrenta el servicio audiovisual público en la mayoría de los países europeos, entre ellos también España.

El primer reto es el de evolucionar en su misión y función del concepto de servicio público de radiodifusión (Public Service Broadcasting, PSB), característico de la mayor parte del siglo XX, y del de servicio audiovisual público (Public Service Media, PSM), con el que se identifica en el tránsito de la última década de los años 90 a los dos primeros decenios del nuevo siglo XXI; para convertirse en servicio público para Internet (Public Service Internet, PSI). La BBC así lo está esbozando en sus planteamientos estratégicos. Su misión, por lo tanto, para la tercera década del siglo XXI y para el reto de la cuarta revolución industrial es convertirse en servicio público de comunicación para la era del Internet de las cosas y de la inteligencia artificial. 


\section{Nueva Directiva europea}

El segundo reto corresponde al ámbito de la regulación y alcanza a todo el conjunto del servicio audiovisual, público y privado, porque le afecta la transposición de la revisión de la Directiva 13/UE/2010 de Servicios de Medios Audiovisuales que debe trasladarse a la legislación de los estados europeos en el plazo de 21 meses a partir de finales de 2018. Esta nueva normativa abarca también a las plataformas y redes digitales, a las que obliga a asumir algunas responsabilidades editoriales y a contribuir con un 30 por ciento de sus ingresos en este mercado a la producción audiovisual europea. De igual manera, para todos los operadores en general se refuerzan las exigencias de protección de los contenidos con respecto a los menores y la prohibición de mensajes xenófobos, de incitación al odio y a la violencia, así como la obligación a los estados de garantizar -con respecto a sus gobiernos y mercadosla independencia de los reguladores de la comunicación.

Así, antes de 2020 España tendrá que haber trasladado a su legislación las directrices de la Directiva europea y, por lo tanto, deberá revisar y reformar tanto la Ley 7/2010 General del Audiovisual, que es la norma básica estatal de referencia, como también las legislaciones audiovisuales de las Comunidades Autónomas con competencias compartidas. Los años 2019 y 2020 exigirán a los parlamentos del estado y de las comunidades autónomas una revisión normativa y estratégica de la comunicación audiovisual en general y de los medios de públicos, en particular. Los retos que se exponen a continuación aparecerán, de una forma u otra, también en los textos y contextos de esas reformas legislativas.

El tercer reto de toda la televisión terrestre española, pública y privada, es afrontar también antes de junio de 2020 la migración de la banda de 700 megahercios de la TDT a la de 470-694 MHz para dar paso a través de la primera a la tecnología $5 \mathrm{G}$ para los operadores de servicios móviles. Esto exige cambiar los sistemas de difusión de la televisión digital terrestre, reorientar las antenas y los canales de captación de las señales a través de los televisores de los hogares. Dará paso al mismo tiempo al sistema DVB-T2, de mejora en la calidad de recepción de la señal, pero exigirá el cambio de la mayor parte de los actuales televisores. 
Estos cambios pueden provocar, como ocurrió en abril de 2010 cuando se llevó a cabo el primer apagón digital, nueva dispersión y fragmentación del consumo porque los usuarios también emigran a otras tecnologías. El impacto tiene importancia social porque la televisión digital terrestre es la tecnología que hasta ahora garantizaba en mejor medida la universalidad y privacidad de acceso a las señales de los contenidos, valores esenciales del servicio audiovisual público. No se sabe que ocurrirá en el futuro porque la tecnología $5 \mathrm{G}$, que tiene toda la próxima tercera década de 2020-30 para su desarrollo, tiene también capacidad técnica para convertirse en plataforma de difusión de la televisión móvil.

En ese escenario tecnológico de evolución y cambio la existencia y presencia del servicio audiovisual público es imprescindible si se quiere mantener el objetivo social de disponibilidad de accesibilidad y universalidad. Por eso, el reto y cambio de la regulación debe contemplar en tal sentido el derecho de must carry, que es la garantía de accesibilidad al servicio público en todas las plataformas de difusión. Porque el servicio audiovisual público de la próxima década debe aspirar y apostar por estar en la nube y en todas las plataformas de difusión para conectarse con el internet de las cosas, las ciudades inteligentes y las tecnologías de realidad aumentada.

La computación y la televisión en la nube es el paradigma de interconexión, navegación y accesibilidad de aquello que está en las redes. Cambia el paradigma de la televisión de continuidad por la de la navegación y el catálogo, con nuevas formas de consumo, nuevos formatos, servicios y modelos de financiación. El mismo concepto de Smart TV o Smartphone trasciende al aparato y a su tecnología para interconectase con otros equipos y servicios inteligentes, sean públicos o privados, de las ciudades, de las empresas o de los propios ciudadanos.

\section{Financiación suficiente y estable}

Para afrontar ese reto y ese cambio tecnológico el servicio audiovisual público necesita financiación suficiente y estable. Es el cuarto reto al que se enfrentan las radiotelevisiones públicas europeas. Porque la financiación de los servicios públicos de radiotelevisión en los países de la Unión Europea ha estado sujeta e influenciada por el impacto de 
la crisis económica de los últimos años, especialmente en aquellos países en los que se llevaron a cabo ajustes económicos más duros. Los medios audiovisuales públicos de España experimentaron uno de los mayores recortes presupuestarios de la UE en el periodo 2010-2016 ($27 \%$ ), sólo superado por los ajustes de Portugal (-30\%) y Grecia ($50 \%)$.

Pero si el signo negativo es el símbolo de los recortes en la primera parte de la segunda década del siglo en los países del sur, el estancamiento y las políticas de ajuste también se extienden en el segundo quinquenio que llega hasta 2020 a los servicios audiovisuales de los estados fuertes del centro y el norte de Europa (Alemania, Dinamarca, Suecia, Austria, Suiza, etc.). Inestabilidad del sistema de financiación del servicio audiovisual público que afecta a la legitimidad y cuestionamiento del modelo de canon como fuente principal de dotación de sus recursos económicos.

El número de países, 18 actualmente en Europa, que aplican el canon como sistema de financiación del servicio audiovisual público se ha reducido en los últimos años y su mantenimiento, también sometido a una alta tasa de evasión e impago (15\% en Irlanda), a la presión e impopularidad de quienes manifiestan que no consumen radiotelevisión convencional y a las campañas de partidos populistas de Alemania, Suiza, Dinamarca, Polonia, etc. ha evolucionado en algunos estados (Finlandia, Dinamarca o Suecia) hacia un impuesto individual incorporado a través de la declaración de la renta de las personas físicas.

El importe medio del canon en Europa en 2017 fue de 135,2 euros por hogar, aunque hay mucha diferencia entre unos y otros países. Se paga este impuesto en Dinamarca, Austria, Suecia, Alemania, Reino Unido, Irlanda, Eslovenia, Francia, Croacia, Bélgica, Italia, República Checa, Polonia, Eslovaquia, Grecia, Portugal y Rumanía. En Finlandia se ha incorporado el cobro a través de los impuestos propios de las empresas y de la renta de las personas físicas, para mayores de 18 años y no desempleados, lo mismo que se prevé para Dinamarca y Suecia en los próximos años. 


\section{Superar la confrontación y polarización}

A la presión financiera se suman otros riesgos y amenazas de diverso tipo e índole. La polarización de los partidos políticos sirviéndose del servicio audiovisual público como territorio de confrontación no es bueno ni para unos ni para otros, pero sobre todo tampoco para la salud democrática de las respectivas sociedades. Esta polarización se expresa en el uso descarado de los medios cuando se domina su control gubernamental y en descalificarlos cuando se está en la oposición o no se puede manipularlos. Se trata de la enfermedad democrática actual y el quinto reto a superar en algunos países fuertemente polarizados por la confrontación política, especialmente de partidos populistas, indistintamente de derechas o de izquierdas.

También es notoria la presión de los usuarios y empresas que no solo abandonan los medios tradicionales, sino que rechazan y denuncian varios casos en los tribunales alemanes- el pago del canon de financiación; la competencia de las empresas privadas no solo tradicionales sino también de los nuevos operadores de telecomunicaciones y plataformas de Internet que absorben la publicidad masivamente; o el impacto sobre la confianza y credibilidad de las fake news, las redes de comunicación partidista y la guerra propagandística de las fuentes digitales (Badourd, 2017).

Frente a los argumentos partidistas y competitivos, la directora general de la ABC de Australia, Michelle Guthrie, cuya corporación también está inmersa en una congelación presupuestaria trianual y enfrentada a los medios privados, se defiende alegando que la "radiotelevisión pública no es un saco de boxeo para estrechos intereses políticos, comerciales o ideológicos porque es necesaria para la democracia y puede convivir con la competencia”. Necesidad que Bart Cammaerts (2016) resume como "el ethos del servicio audiovisual público tiene lógica basado en una producción cultural y cultura democrática diferenciada de la comercial".

La preocupación sobre el servicio audiovisual público se ha acrecentado en los últimos años, ampliando y profundizando el debate no sólo sobre sus amenazas y el papel que le puede corresponder en el ecosistema digital, sino también sobre las atrofias o incapacidades internas que le impiden responder a los retos externos. La European 
Communication Research and Education Association (ECREA), la mayor asociación de investigadores europeos de la comunicación, suscribía esa preocupación encabezada por Van den Bulck, Brougton Micova y Milosavljevic (2018), tres de los principales estudiosos de la regulación de los medios públicos.

\section{Gobernanza y valores}

La reforma de la gobernanza se puede marcar como el sexto reto. La preocupación por el refuerzo de la legitimidad de los medios públicos es otra de las líneas fuertes de las estrategias y acciones de las corporaciones audiovisuales que prestan dichos servicios. Está presente en las reformas y aplicaciones de su gobernanza, transparencia, rendición de cuentas y responsabilidad.

La forma de selección de los miembros de los órganos de gobernanza mediante procedimientos de convocatoria, concurso público y evaluación a cargo de comités de expertos se ha impuesto en varios países, pero aún no hay perspectiva temporal para valorar si este sistema resulta más eficiente que los anteriores para mejorar la independencia y la buena gestión de las corporaciones del servicio audiovisual público. Pese a esa poca perspectiva temporal, se siguen apreciando notables influencias e interferencias de los partidos políticos en los distintos procesos de designación. Falta por ver, como sería deseable, que dichos procesos incrementen las garantías de idoneidad de las designaciones, su calidad y cualidades, la transparencia y la mejora general de la independencia de la gobernanza.

La adaptación de los valores de servicio público de la tríada de principios fundacionales con la que John Reith creó la BBC hace casi cien años (información, formación y entretenimiento) a la actual era de Internet y al escenario de convergencia con los servicios de la cuarta revolución industrial es el séptimo reto de la radiotelevisión pública para los próximos años. La Unión Europea de Radiodifusión convirtió en 2012 estos tres valores fundacionales en seis (universalidad, calidad, independencia, diversidad, innovación y rendición de cuentas), necesarios para el servicio audiovisual público. A ellos es necesario incorporar otros aspectos o valores emergentes de la sociedad digital actual. 


\section{Innovación y alfabetización}

La innovación es el octavo hito necesario para la transformación del servicio audiovisual público. La innovación es una línea estratégica para reforzar no solo la supervivencia de los radiodifusores públicos europeos sino también el posicionamiento competitivo y sostenible a largo plazo. Su cometido es incrementar la cultura del cambio en las organizaciones, promover el talento y la creatividad, desarrollar nuevos enfoques y contenidos, captar nuevos públicos sin perder los actuales, fomentar la competitividad de las instituciones, así como abrir nuevos espacios de participación e interacción tanto con las audiencias como con la sociedad a través de la comunicación.

La innovación abierta es la tendencia que cobra fuerza en el servicio audiovisual público europeo, saliendo de los laboratorios que sirvieron para introducir esa prioridad de renovación en las organizaciones tradicionales a la transversalidad de todas sus estructuras y a la conexión directa con la participación de las empresas externas, así como de la sociedad de su entorno, en general.

Para que sea eficaz a la transformación de las organizaciones, la innovación tiene que ser transversal y no puede ser solo un discurso ejecutivo, una operación de marketing relacional ni una tarea de uno o dos departamentos o laboratorios. La innovación es una herramienta de cambio y, por tanto, tiene que penetrar y transformar la cultura organizacional.

La innovación es necesaria también para la reorganización en 360 grados y para el rediseño de las estructuras del servicio audiovisual público en función del nuevo ecosistema de producción, difusión, consumo y uso de la información. Ampliación y adaptación de la misión del servicio público de radiodifusión (PSB) a la del servicio de medios audiovisuales públicos (PSM), es decir, el paso de la radiotelevisión de continuidad a la provisión de contenidos para el acceso a la navegación en la nube y la televisión social interconectada a través de las redes.

En este contexto de innovación destaca en igual medida la misión educativa y formativa que debe tener el servicio audiovisual público. El noveno reto es la alfabetización mediática. La educación del siglo XXI necesita comprender y entender bien el significado de la tercera y cuarta 
revoluciones, de la información y la inteligencia artificial. Es una tarea que requiere una nueva alfabetización, objetivo planteado institucionalmente ya en la Agenda Digital Europea y que algunas radiotelevisiones públicas han desarrollado o están incorporando en sus agendas estratégicas. $\mathrm{Y}$ en esa nueva alfabetización entra la preocupación, explicación y enfrentamiento al doble problema de las fake news y de la pérdida de confianza en las instituciones.

En décimo lugar, aunque no en menor importancia que cualquiera de los anteriores, está la reafirmación del valor social del servicio audiovisual frente a los valores de cambio y uso. Es el reto de fundamentación y reafirmación de todos los anteriores. La plasmación de su valor social es la fuente de legitimidad y el gran reto que la prestación del servicio audiovisual público tiene que convertir en realidad para justificar su necesidad, credibilidad y confianza. Convertirlo en realidad es la responsabilidad de su gobernanza y gestión.

\section{Necesidades y mejoras}

Con esos diez retos principales por delante se pueden apuntar a continuación también las siguientes líneas de necesidades y aspiraciones del servicio audiovisual público para los próximos años:

- Necesidad de reforzar la legitimidad del servicio audiovisual público mediante el fortalecimiento de su confianza y credibilidad frente a la competencia creciente de los operadores globales ajenos a los intereses sociales y económicos estratégicos de las respectivas comunidades, estados y Unión Europea.

- Mejorar y proteger la independencia, transparencia y rendición de cuentas de su gobernanza para incrementar esa confianza y credibilidad.

- Financiación suficiente, sostenible, previsible, plurianual e independiente abriendo y permitiendo nuevos modelos de dotación de recursos que compatibilicen esas cinco características. 
- Lograr regulación tecnológica para garantizar el mantenimiento de la universalidad de presencia de los servicios audiovisuales públicos en las plataformas digitales.

- Reorganización 360 grados de las estructuras del servicio audiovisual público en función de la nueva dimensión del ecosistema mediático digital de producción, difusión y consumo.

- Avanzar en la estrategia digital para convertirla en prioridad con la prelación de uso y preferencia por parte de las audiencias. Es decir, invertir el paradigma actual de la producción y difusión tradicional por el de digitization first con el objetivo de adaptarse a la migración de las audiencias.

- Presencia del servicio audiovisual público a través de nuevas formas de distribución, acceso e interacción de los servicios audiovisuales en la nube, en las redes y las plataformas digitales, propias y ajenas.

- Orientación del servicio audiovisual público a la convergencia con los nuevos servicios públicos inteligentes del Internet de las cosas, de uso de la inteligencia artificial, de aplicación del blockchain y de ciudades inteligentes.

- Ampliación de la tradicional dimensión audiovisual para contribuir, como propone la BBC, a la creación de un servicio público de Internet que promocione los valores públicos esenciales, tratamiento de los datos personales como bien público y garantía de su privacidad, enriquecimiento de la esfera digital y consolidación de una red confiable de servicios públicos digitales.

- Aculturación digital de todos los recursos humanos de las organizaciones tradicionales del servicio audiovisual público y aceleración de la innovación para avanzar en la adaptación de las estructuras al nuevo ecosistema de la competencia mediática.

- Avanzar de la innovación de laboratorio (innovation lab) a la innovación abierta (open innovation) abriendo las ventanas de la 
organización al talento y a la creatividad externa, propiciando también la co-creación y participación directa de las audiencias.

- Asumir y desarrollar la misión de alfabetización mediática para trasladar a la sociedad el valor del servicio audiovisual público y su importancia frente a la circulación de las fake news.

- Incluir en la gestión de la Responsabilidad Social Corporativa nuevos valores emergentes de la sociedad que sean coherentes con la misión y encomienda del servicio audiovisual público.

- Incorporar la evaluación del valor económico y social agregado de los servicios audiovisuales públicos para mejorar la rendición de cuentas y la creación de nuevas narrativas de comunicación para mejorar la reputación y la confianza ante los ciudadanos.

\section{Temáticas de estudio}

Mostradas esos retos y esas necesidades de mejora del servicio audiovisual público pasamos a presentar las temáticas y autorías que dan cuerpo de investigación a este libro a través de los siguientes 10 trabajos.

El primer trabajo de este Cuaderno Artesano de Comunicación estudia las narrativas inmersivas en vídeo $360^{\circ}$ publicadas por el Laboratorio de Innovación Audiovisual de RTVE, Lab RTVE.es, entre 2015 y 2017. Sus autoras, María José Benítez de Gracia y Sara Pérez-Seijo parten de una metodología mixta para ahondar en el uso de este tipo de narrativas por parte de la corporación pública, para poder después establecer una serie de recomendaciones y buenas prácticas en torno al periodismo inmersivo.

Laura Caballero Trenado ofrece en su capítulo una completa reflexión sobre uno de los retos que apuntábamos al inicio de este prólogo: los desafíos regulatorios que plantea la nueva Directiva de Servicios de Comunicación Audiovisual. La autora detalla los principales cambios que plantea la revisión de la Directiva en un contexto en el que la radiotelevisión pública debe redefinir su modelo ante el nuevo ecosistema digital, marcado por la imparable competencia de las 
plataformas digitales y por la consolidación de nuevas formas de consumo de contenidos audiovisuales.

El tercer capítulo del presente cuaderno aborda otra cuestión crítica en el marco de los retos del sistema audiovisual público: la transparencia. Carmen del Rocío Monedero Morales y Silvia Olmedo Salar desarrollan y aplican un indicador para medir el grado de transparencia y rentabilidad social que reflejan las páginas web de los principales canales nacionales generalistas públicos del Suroeste Europeo. Así, las autoras presentan una herramienta que enfatiza la rentabilidad social de los medios públicos a través de su gestión, pluralidad, diversidad de programación y contenidos y aplicación de las nuevas tecnologías.

Fermín Galindo Arraz y Juan Carlos Regueira Rey estudian la cobertura informativa de los procesos electorales en la televisión pública desde la perspectiva de la innovación. Este tipo de coberturas informativas están estrictamente reguladas y suponen un esfuerzo presupuestario notable para los medios públicos. Por ello, los autores plantean aplicar estrategias de innovación también en este cambio, apoyándose en el análisis de la cobertura específica realizada durante la última década por la CRTVG, la televisión pública autonómica gallega.

La transparencia vuelve a ser objeto de estudio en el quinto capítulo de este Cuaderno Artesano de Comunicación, en el que Ana María López Cepeda, Belén Galletero Campos e Inmaculada Teruel Carrión analizan el nivel de transparencia y disponibilidad de la información de las televisiones públicas autonómicas en España a través de sus páginas web corporativas. La aplicación de un sistema de indicadores preexistentes, el análisis de la legislación vigente y la revisión de la literatura científica permiten a las autoras establecer una comparativa entre los medios de comunicación públicos autonómicos.

Por su parte, Kruzkaya Ordóñez y Catalina Mier presentan un análisis del tratamiento informativo audiovisual del conflicto que Ecuador mantiene en su frontera norte con la disidencia colombiana en distintas cadenas de televisión internacionales (Caracol Noticias, El Espectador, Ecuavisa, RT y la BBC). Las autoras aplican tres indicadores (relevancia informativa, fuentes y enfoque) a la cobertura del día 13 de abril de 2018 para estudiar si las noticias emitidas a nivel internacional 
emplearon a los medios ecuatorianos o a los colombianos como su primera fuente de información.

Javier Pérez Sánchez aborda en el capítulo siete otro de los grandes retos de los medios de comunicación públicos, la competencia creciente de las plataformas audiovisuales bajo demanda. El autor define las principales diferencias, retos y oportunidades de las radiotelevisiones públicas nacionales de Italia y España frente a la instalación de nuevos operadores on demand como Netflix en estos contextos.

En el octavo capítulo, Iván Puentes-Rivera y Paulo Carlos LópezLópez recuperan la discusión sobre las políticas y estrategias de transparencia de las radiotelevisiones públicas europeas. Los autores presentan una reflexión sobre la importancia del compromiso con la transparencia de los medios públicos, partiendo de un análisis comparativo de las políticas de transparencia vigentes en la Unión Europea y proponiendo después una serie de indicadores cuya aplicación permita valorar la política de comunicación y empresa de las radiotelevisiones públicas.

Begoña Zalbidea, Idoia Camacho, Jose Mari Pastor y Santi Urrutia plantean un estudio sobre la presencia de las televisiones públicas españolas en el agregador de contenidos Menéame. El análisis de una muestra aleatoria de 400 portadas de esta web entre 2006 y 2015 concluye que los medios de comunicación públicos apenas han tenido relevancia en Menéame, al constituir tan solo el 0,7\% de los enlaces incluidos en esta red social.

Este Cuaderno Artesano de Comunicación lo cierra el único trabajo que no tiene como objeto de estudio directo a los medios de comunicación públicos. Sin embargo, el sistema experto de análisis financiero que presentan Ana Cecilia Vaca-Tapia, Francklin Iván Rivas-Echeverría y Johnny Alejandro Aragón-Puetate, aplicado en este caso a las televisiones privadas ecuatorianas Teleamazonas y Ecuavisa, podrá ser aplicado en futuros trabajos a los medios de comunicación de titularidad estatal, permitiendo así analizar su optimización de recursos y el proceso de toma de decisiones para el crecimiento empresarial. 
La TV pública en Europa: Innovación, Retos y Tendencias cierra la trilogía iniciada en el volumen Innovación en Comunicación. Retos en la TV pública europea y en el periodismo móvil y continuada en la segunda parte, Debates sobre valores e indicadores del servicio audiovisual público en Europa, todos ellos enmarcados en las acciones de difusión del proyecto CSO201566543P-MINECO-FEDER ("Indicadores de gobernanza, financiación, rendición de cuentas, innovación, calidad y servicio público de las RTV europeas aplicables a España en el contexto digital" del Programa estatal de Fomento de la Investigación Cientifica y Técnica de Excelencia, subprograma estatal de Generación de Conocimiento del Ministerio de Economia y Competitividad de España, cofinanciado por el Fondo Europeo de Desarrollo Regional (FEDER) de la Unión Europea).

\section{Bibliografía}

Badourd, R. (2017). El desencanto de Internet. Desinformación, rumores y propaganda. Limoges: Ed. FYP.

BBC (2018). BBC Annual Plan 2018/19. Acceso: https://goo.gl/VYMft7.

Cammaerts, B. (2016). A recipe for a right-wing assault on public service media? Acceso: https://goo.gl/5Mhtiv.

Dörr, D., Holznagel, B. y Picot, A. (2016). Legitimation und Auftrag des öfertlich-rechtlichen Fernsehens in Zeiten der Cloud. Londres: Peter Lang.

Dragomir, M (218). The Perils of Public Media Founding. Acceso: https://goo.gl/XVNdWg.

Fuchs, Ch. (2017). The Online Advertising Tax as the Foundation of a Public Service Internet. Londres: University of Westminster Press.

Ramsey, Ph. (2017). Public Service Media funding in Ireland faces continuing challenges. Acceso: https://goo.gl/Gbjzfz. 
Saner, M. (2018). Beobachtung der Wahlberichterstattung des Regionaljournals Zurich Schaffhausen. Acceso: https://goo.gl/EYk63j.

Van den Bulck, H., Broughton Micova, S.; Milosavljevic, M. (2018). Ecreans engaged: Communication law and policy: issues of concern. Acceso: https://goo.gl/yosKJg.

Van den Bulck, H.; Donders, K.; Ferrell, G. (2017). Public Service Media in the Networked Society. What Society? What Network? What role? Gothemburg: Nordicom.

\section{Francisco Campos-Freire Miguel Túñez-López Marta Rodríguez-Castro}

Universidade de Santiago de Compostela

PARA CITAR: Campos-Freire, F., Túñez-López, M. y RodríguezCastro, M. (2018). Retos 2020-30 para el servicio audiovisual público. En Rodríguez-Castro, M., Pérez-Seijo, S. y Campos-Freire, F. (Eds.) (2018). La TV pública en Europa: Innovación, Retos y Tendencias (9-22). Cuadernos Artesanos de Comunicación, cac 146. La Laguna (Tenerife): Latina. DOI: $10.4185 /$ cac146. 


\title{
Análisis de las narrativas inmersivas en vídeo $360^{\circ}$ publicadas por el Lab RTVE.es (2015-2017)
}

\author{
María José Benítez de Gracia \\ Universidad Carlos III de Madrid \\ Sara Pérez-Seijo \\ Universidade de Santiago de Compostela
}

PARA CITAR: Benítez de Gracia, M. J. y Pérez Seijo, S. (2018). Análisis de las narrativas inmersivas en vídeo en $360^{\circ}$ publicadas por el Lab RTVE.es (20152017). En Rodríguez-Castro, M., Pérez-Seijo, S. y Campos-Freire, F. (Eds.). La TV Pública en Europa: Innovación, Retos y Tendencias (23-47). Cuadernos Artesanos de Comunicación, cac 146. La Laguna (Tenerife): Latina. DOI: 10.4185/cac146.

\section{Resumen}

El desarrollo y la experimentación con nuevas narrativas audiovisuales rigen la vocación innovadora que Radio Televisión Española promueve desde la creación en 2011 del Laboratorio de Innovación Audiovisual de RTVE, Lab RTVE.es. En los últimos años, la convergencia en el mercado de una serie de tecnologías vinculadas al vídeo $360^{\circ}$ ha contribuido a que los formatos inmersivos adquieran un papel destacado dentro de esta área. Enmarcados dentro del denominado periodismo inmersivo, este tipo contenidos ofrecen como novedad y ventaja la posibilidad de acercar al espectador en primera persona al acontecimiento que está siendo representado con un alto grado de realismo, como si verdaderamente estuviera allí. Este trabajo ofrece un análisis descriptivo de la evolución y las características de los 
proyectos inmersivos en vídeo $360^{\circ}$ publicados por el Lab RTVE.es entre 2015 y 2017. Se emplea una metodología mixta que combina un análisis de contenido con dos métodos cualitativos: una entrevista y un estudio de caso. La triangulación de los resultados permite interpretar con mayor nivel de detalle el empleo de este tipo de narrativas inmersivas por el Lab RTVE.es. Como conclusión se dan una serie de recomendaciones y buenas prácticas para aprovechar las ventajas y el potencial que ofrecen este tipo de contenidos que pueden servir de guía a quienes tratan de comprender e iniciarse en este nuevo formato.

Palabras clave: innovación, periodismo inmersivo, vídeo $360^{\circ}$, labs, medialabs, Lab RTVE.es

\section{Introducción}

En junio de 2011 el ecosistema mediático español presenció el nacimiento del primer laboratorio de innovación periodística dentro de un medio de carácter público. Radiotelevisión Española había decidido constituir el Laboratorio de Innovación Audiovisual de RTVE, más conocido como Lab RTVE.es. La radiodifusora ponía en marcha este departamento de innovación con un marcado objetivo: implementar, desarrollar y experimentar con las narrativas audiovisuales más recientes y novedosas, así como trabajar con nuevos formatos en la producción de contenidos (García-Avilés, 2018).

Este departamento centrado en la innovación periodística y audiovisual, en palabras de su responsable, Miriam Hernanz, "trata de acercar los temas tradicionales a través de nuevas formas que mezclan tecnología y contenido y hacer que sea una experiencia diferente para el usuario" (Hernanz, 2017). Conforme a este propósito, los contenidos inmersivos en vídeo $360^{\circ}$ se han convertido en un valor de referencia que, en los últimos cuatro años, se ha materializado en 19 proyectos directamente publicados por el Lab RTVE.es.

Estas producciones han sido posibles, principalmente, por dos motivos. En primer lugar, por el impulso, la evolución y el abaratamiento que han experimentado las tecnologías inmersivas, en concreto, las implicadas tanto en el proceso de producción de vídeo $360^{\circ}$-cámaras, soportes o rigs, software-, como aquellas necesarias para su visualización -gafas VR y cardboards-, y su distribución. En 
segundo lugar, y vinculado a esta combinación de tecnología y contenido, por la doble ventaja que ofrecen ya que, siguiendo a Hernanz, no solo ayudan a "empatizar, ponerse en la piel de otras personas y llegar a sentir lo que ellos piensan o lo que ellos sienten, huelen o tocan", sino que "acercan al espectador a sitios que nunca podría pisar, como el planeta Marte o el CERN” (Hernanz, 2017).

\subsection{Narrativa inmersiva como fórmula de innovación en Lab RTVE.es}

La estrategia adoptada por RTVE a través del Lab RTVE.es se enmarca en el afán general de las radiotelevisiones públicas europeas por seguir el ritmo de la carrera de innovación mediática que caracteriza a la segunda década del siglo XXI. Una carrera que busca frenar la obsolescencia que acecha a los entes de servicio público. Tal es así que, a partir de 2010 diversas radiodifusoras han creado laboratorios, departamentos o, en su defecto, células internas de innovación dedicadas a la experimentación con nuevos formatos, narrativas, lenguajes e incluso soportes. Así ha sido el caso de televisiones como British Broadcasting Corporation (Reino Unido), con laboratorios como Taster y BBC News Lab, Radio Télévision Belge Francophone (Bélgica), con la célula WebCréation, o France Télévisions (Francia), con Nouvelles Écritures. Al margen del ya mencionado Lab RTVE.es de Radiotelevisión Española.

Autores/as como Sádaba y Salaverría (2016) conciben los laboratorios de innovación, también denominados medialabs o labs, como "una unidad interna de la empresa periodística, dotada de cierto grado de autonomía operativa y equipo humano propio, cuyo cometido es idear y promover innovaciones de carácter tecnológico, editorial y/o comercial, para la mejora competitiva de la organización" (p. 153). La vocación de estos equipos multidisciplinares es, por tanto, incentivar la innovación dentro del propio medio, una meta que tratan de alcanzar mediante la creación y desarrollo de proyectos novedosos (Sádaba y Salaverría, 2016). El Lab RTVE.es, por ejemplo, se centra desde en torno el 2015 en la producción de contenidos interactivos en los que el usuario dispone de un mayor nivel de interacción y participación durante el consumo del relato, así como también de trabajos con recursos como la realidad virtual y el vídeo $360^{\circ}$. 
En concreto, los intereses principales del Lab RTVE.es se articulan en torno a tres formatos y/o narrativas: los webdocs, los interactivos y los trabajos inmersivos, estos últimos normalmente en vídeo $360^{\circ}$. Una tríada que forma parte del propio menú de navegación de la página web del Lab RTVE.es -datos de agosto de 2018-, de ahí también su relevancia (Figura 1).

Por un lado, se encuentran los llamados webdocs, un formato que hibrida el documental interactivo con los juegos informativos. Vázquez-Herrero y López García (2016) lo definen como "una forma que representa una parte de la realidad con ayuda de la hipertextualidad, la multimedialidad y la interactividad" (p. 3). Uno de los rasgos característicos de estos trabajos, también conocidos como docugames, es la participación que requieren del usuario (Nash, 2015), lo que le permite atesorar un papel activo al poder tomar decisiones en la historia (Paíno, Rodríguez y Ruiz, 2017).

Figura 1. Captura del menú de la página web el Lab RTVE.es

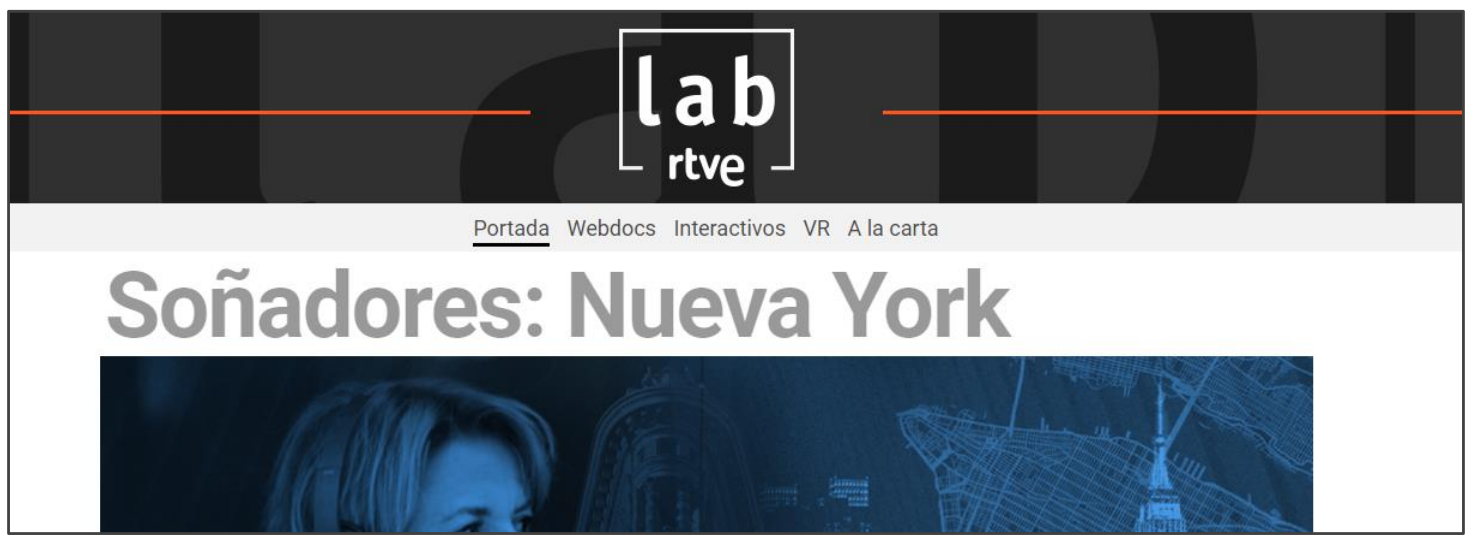

Fuente: captura de la web http://www.rtve.es/lab/

Montela $^{1}$ ha sido uno de los primeros webdocs producidos por el Lab RTVE.es. Este proyecto, impulsado y creado en 2014 desde el propio laboratorio, traslada al usuario al año 2007, justo antes del estallido de la burbuja inmobiliaria en España. Este trabajo, a caballo entre el juego informativo y el documental, presenta una lógica singular: el usuario no consume una historia, sino que interactúa con ella a la par que aprende y se informa del tema. A través de este proyecto se invita al usuario a simular que forma parte de una familia que acaba de comprar un piso y se le pide que tome una serie de decisiones, estas de carácter

${ }^{1}$ Webdoc disponible en: http://lab.rtve.es/montelab/ 
económico, que repercutirán directamente tanto en su bolsillo como en la propia felicidad de su familia ficticia.

En 2016 el Lab RTVE.es estrenó Que tiemble el camino², otro webdoc en el que la información y el juego se aúnan para ofrecer al usuario una experiencia más interactiva. Este trabajo sumerge al receptor en una aventura en la que deberá ayudar a un grupo de peregrinos con párkinson a completar $108 \mathrm{~km}$ del Camino de Santiago (parte gamificación) mientras los va conociendo (parte documental).

Ambos proyectos se enmarcan en lo que se denomina gamificación (Kapp, 2012), que consiste en la aplicación de recursos narrativos, técnicas de diseño y lógicas propias de los videojuegos a los contenidos de no ficción, véase el caso del campo periodístico. Un interés que fue aumentado a medida que avanzaba la digitalización del siglo XXI (Domínguez, 2015). El ejemplo paradigmático lo constituyen los llamados newsgames, término acuñado por Gonzalo Frasca (2007).

Al margen de los webdocs, el Lab RTVE.es también incluye en su menú una categoría denominada "interactivos". Bajo esta etiqueta se agrupan trabajos como los reportajes multimedia Refugiados en España: en el limbo del asilo ${ }^{3}$ (2016) o El Trampolin ${ }^{4}$ (2016), cortos interactivos como Tu primer día en El Caso $0^{5}$ (2016) o, entre otros, mapas de personajes de series como Isabel, producto emitido en televisión por Radiotelevisión Española.

Precisamente una de las tareas que los laboratorios de innovación deben llevar a cabo es la búsqueda de las últimas tendencias en producción, especialmente aquellas más vinculadas a la tecnología digital (Del Campo y Zaragoza, 2017). El Lab RTVE.es da cuenta de ello con su inversión e interés en las llamadas tecnologías inmersivas, como la realidad virtual y las cámaras $360^{\circ}$. Con todo, la Unión Europea de Radiodifusión (EBU o UER por su siglas en inglés y

${ }^{2}$ Webdoc disponible en: http://lab.rtve.es/webdocs/parkinson-que-tiemble-el$\underline{\text { camino/ }}$

${ }^{3}$ Disponible en http://lab.rtve.es/crisis-refugiados/

${ }^{4}$ Disponible en http://lab.rtve.es/rio-2016/

${ }^{5}$ Corto interactivo de la serie de televisión El Caso: Crónica de sucesos, disponible en http://lab.rtve.es/el-caso/

${ }^{6}$ Disponible en http://lab.rtve.es/serie-isabel/personajes/ 
español, respectivamente), alianza internacional de medios públicos de la que la radiotelevisión española forma parte, ha fomentado entre sus miembros la experimentación con estas narrativas proporcionando plataformas u organizando encuentros con el propósito de que las radiotelevisiones públicas europeas compartan experiencia y conocimiento en cuanto a producción inmersiva se refiere (European Broadcasting Union, 2017).

El empleo de estos elementos en los contenidos de no ficción ha dado paso a nuevas formas de contar, producir, distribuir e incluso consumir la información. Por ello, actualmente se habla de narrativas inmersivas cuando se alude al empleo de la realidad virtual y de las imágenes esféricas -tanto las estáticas (fotografía $360^{\circ}$ ) como las que cuentan con movimiento (vídeo $360^{\circ}$ ) - en la narración. Estos recursos se han introducido en los medios de comunicación como una vertiente evolutiva del multimedia gracias a las nuevas posibilidades que abren a la hora de presentar no solo la imagen, sino el texto y el sonido.

No obstante, las primeras experiencias prácticas con estas narrativas se remontan a los trabajos que algunas universidades estadounidenses desarrollaron en la década de los 90 (Domínguez, 2013). Sin embargo, hasta finales de 2015 no se observó el inicio de una experimentación general por parte del panorama mediático mundial (Doyle, Gelman y Gill, 2016). Con todo, antes de esta explosión se encuentran trabajos destacados que, en cierta medida, favorecieron el empleo de las narrativas inmersivas por parte de los medios. Por un lado, los trabajos liderados por la investigadora Nonny de la Peña, como es el caso de Hunger in LA, presentado en la edición de 2012 del Sundance Film Festival. Esta pieza recrea un incidente ocurrido frente a una iglesia de Los Ángeles (Domínguez, 2013): un hombre cae en coma diabético mientras espera en la cola para comer en el recinto religioso. De la Peña y su equipo recrearon el suceso mediante el empleo de la realidad virtual, pero optaron por complementarlo con audios reales del momento (Domínguez, 2015).

Unos años más tarde, en 2014, el diario estadounidense Des Moines Register publicó Harvest of Change, un trabajo pionero realizado con la herramienta Unity, utilizada en el sector de los videojuegos (Longhi, 2017), que traslada al usuario a una granja recreada con realidad virtual para explicar la influencia y el impacto que cambios como los 
demográficos y los económicos han tenido en la industria granjera de Iowa.

Cabe destacar que el uso de las llamadas narrativas inmersivas en el campo de la información recibe el nombre de Periodismo Inmersivo. De la Peña et al. (2010) bautizaron así a una corriente periodística que concibieron como "la producción de noticias mediante un método que permite a la gente obtener experiencias en primera persona de los eventos o situaciones descritas en los relatos informativos" (p. 291).

De acuerdo con Domínguez, "el conocimiento humano aumenta con la experiencia en primera persona de un mundo creíble" (Domínguez, 2013: 293). Siguiendo a esta autora, para lograr esta representación es necesario el uso de una serie de recursos narrativos que fundamentan lo que denomina la retórica inmersiva, algunos de los cuales se pueden aplicar al vídeo $360^{\circ}$. Entre ellos, el realismo de la representación, la eliminación de cualquier evidencia de mediación o artificio en el relato, el uso del sonido ambiental, la elección por el usuario del encuadre de la escena y la personificación del usuario en un personaje, asumiendo un rol en el relato (p.299).

RTVE lleva varios años experimentando con las narrativas inmersivas: en coberturas informativas, como el vídeo $360^{\circ}$ en los encierros de San Fermín 2016 $6^{7}$ en productos culturales de entretenimiento, caso de la grabación de la obra de teatro La Cocina ${ }^{8}$ (2016) también con vídeo esférico, o incluso en productos de ficción, como la grabación de El tiempo en tus manos (2016), un episodio en realidad virtual de la serie El Ministerio del Tiempo. Una tarea que la radiodifusora española lleva a cabo, justamente, a través de su laboratorio de innovación.

Si bien en párrafos anteriores se comentaba que las narrativas inmersivas se articulan en torno a dos recursos principales, la realidad virtual y las imágenes $360^{\circ}$, cabe decir que cada uno de estos elementos deriva en formatos distintos: por un lado, las recreaciones sintéticas con realidad virtual; y, por otro, fotografías y vídeos $360^{\circ}$, dependiendo de si la imagen incluye o no el movimiento de la escena. No obstante,

\footnotetext{
7 Encierros 360, disponible en: http://www.rtve.es/noticias/san-fermin/360grados/
}

${ }^{8}$ Disponible en http://lab.rtve.es/escena-360/la-cocina/?load=1 
es el vídeo esférico el formato más empleado por los medios de comunicación (Hardee y McMahan, 2017).

Entre las ventajas de los vídeos $360^{\circ}$ se encuentran los modos de visionado. Si el usuario realiza el consumo desde un dispositivo móvil, hacia donde tiende precisamente la producción, se podrá topar con tres posibilidades: puede descubrir el escenario del mundo narrativo interactuando de manera manual en la pantalla, esto es, deslizando el dedo (Longhi, 2017); puede girar directamente el dispositivo arriba, abajo, derecha o izquierda gracias a la función del giroscopio que, por lo general, los dispositivos actuales incluyen; o puede acoplar el smartpthone a unas gafas de realidad virtual o, en su versión de bajo coste, herramientas como las Google Cardboard (Hardee y McMahan, 2017; Tse et al., 2017) para observar el entorno en $360^{\circ}$, en esta ocasión, gracias al movimiento de su cabeza.

El Lab RTVE.es ha producido contenidos que permiten ambas visiones, la móvil o ventana mágica (Tse et al., 2017) y la que requiere de las gafas de realidad virtual. Los trabajos que ha estado realizando desde 2015, momento en el que estrena el trabajo multimedia Ingeniería Romana' presentan no solo diversos modos de consumo, sino también diferentes vías de distribución. Como se podrá comprobar a lo largo de este estudio, el Lab RTVE.es publica sus contenidos en diferentes plataformas: desde su propia web, hasta en perfiles/cuentas oficiales de Facebook y YouTube. No obstante, también se encuentran casos de apps propias dedicadas a proyectos muy concretos, como es Cervantes VR (2017), un trabajo en clave teatral que se centra en la vida del escritor Miguel de Cervantes a través de su obra Don Quijote de la Mancha.

\footnotetext{
${ }^{9}$ Ingeniería Romana es un proyecto multimedia e interactivo centrado en la historia de Tarraco, antigua ciudad romana. Entre los materiales que conforman el trabajo se encuentran cuatro vídeos $360^{\circ}$ que trasladan al receptor, gracias al vídeo esférico y a la recreación con realidad virtual, a diversos lugares que antaño formaban parte de la ciudad. Estas localizaciones dan precisamente nombre a las piezas: Circo, Recinto de culto, Foro de la colonia y Anfiteatro (Pérez-Seijo y Benítez de Gracia, 2018). Puede consultarse en http://lab.rtve.es/ingenieriaromana/
} 


\section{Metodología}

El presente trabajo tiene como objeto de estudio los proyectos inmersivos publicados por el Lab RTVE.es en vídeo $360^{\circ}$, durante el período de tres años comprendido desde 2015, fecha en la que este medio comienza a publicar las primeras piezas en este formato, hasta diciembre de 2017. Con ello se pretende determinar si existen elementos básicos comunes en este tipo de trabajos, así como valorar el uso de algunos recursos propios de la narrativa inmersiva.

Se ha optado por una metodología mixta, cuantitativa y cualitativa, que parte de la técnica del análisis de contenido. Para la designación de las variables y de las categorías se han combinado dos modelos de análisis empleados con éxito en estudios recientes centrados en este tipo de narrativas: el Modelo de Construcción Informativa Audiovisual Eficaz o MOCIAE, diseñado por Morales (2012) para examinar las acciones llevadas a cabo en cada fase del proceso de producción periodística (Pérez-Seijo, López-García y Campos-Freire, 2018) y el modelo de análisis de contenido para el reportaje inmersivo en $360^{\circ}$ propuesto por Benítez y Herrera (Benítez y Herrera, 2018). Para extraer las diferentes unidades de análisis se ha realizado una búsqueda en la web del medio, www.rtve.es, así como en sus respectivos canales oficiales de Youtube y Facebook; y utilizado diversos términos de búsqueda: vídeo $360^{\circ}$, $360^{\circ}, 360$ video, realidad virtual, vr, inmersivo y vídeo vr. La muestra obtenida se compone de 19 proyectos que se han codificado en Excel a partir de un sistema de cuantificación nominal y exportado posteriormente al software SPSS (versión 24.0) para el tratamiento de los datos.

Posteriormente, estos resultados se han triangulado con dos técnicas de investigación cualitativas: una la entrevista en profundidad, por la información pormenorizada que añade (Wimmer y Dominick, 1996: 158), y un estudio de caso que puede contribuir a "lograr un mayor aprovechamiento interpretativo" (p. 161). La entrevista se realiza a Miriam Hernanz, responsable del Lab RTVE.es, en dos momentos distintos, abril de 2016 y mayo de 2018, lo que permite ofrecer una versión actualizada respecto a la experiencia y motivaciones de la entrevistada a lo largo del tiempo. El estudio de caso se centra en Vive Rio: Heroínas, uno de los primeros reportajes inmersivos publicados por 
Lab RTVE.es, en julio de 2016. Para ello se han extraído algunas de las aportaciones de Miriam Hernanz en sendos momentos de la entrevista, así como las conclusiones obtenidas tras asistir una de las autoras, concretamente Benítez de Gracia, a una jornada de trabajo en la sede de la productora InMediaStudio donde se desarrolló el proyecto.

\section{Resultados}

Dentro de la muestra de estudio compuesta por 19 piezas inmersivas en vídeo $360^{\circ}$, los primeros resultados del análisis de contenido ofrecen algunas de sus características básicas (fecha, duración, tema, distribución, etc.). Paralelamente, se han analizado otro tipo de recursos propios de la narrativa inmersiva (altura de la cámara, focalización, continuidad entre escenas, uso de sobreimpresiones, rol del espectador, representación del espectador, interacciones, etc.) a fin de detectar su existencia y valorarlas.

Junto a este análisis, se muestran los resultados de la entrevista en profundidad y los obtenidos a través del estudio de caso del reportaje Vive Rio: Heroinas.

\subsection{Resultados del análisis de contenido}

Entre 2015 y 2017 el Lab RTVE.es ha publicado un total de 19 proyectos inmersivos en vídeo $360^{\circ}$, cuyas características básicas se resumen en la Tabla 1:

Tabla 1: Características generales de los proyectos en $360^{\circ}$ publicados por Lab RTVE.es

\begin{tabular}{|c|c|c|c|c|c|}
\hline & Fecha & Duración & $\begin{array}{l}\text { Plataformas de } \\
\text { distribución }\end{array}$ & App & Tema \\
\hline $\begin{array}{l}\text { Ingeniería Romana - E1 } \\
\text { anfiteatro }\end{array}$ & 2015 & $2: 28$ & $\begin{array}{l}\text { Youtube, app, web } \\
\text { del medio, Facebook }\end{array}$ & $\begin{array}{l}\text { Imageen } \\
\text { Tarraco }\end{array}$ & Cultura \\
\hline Ingeniería Romana - El foro & 2015 & $1: 28$ & $\begin{array}{l}\text { Youtube, app, web } \\
\text { del medio, Facebook }\end{array}$ & $\begin{array}{l}\text { Imageen } \\
\text { Tarraco }\end{array}$ & Cultura \\
\hline $\begin{array}{l}\text { Ingeniería Romana - E1 } \\
\text { recinto de culto }\end{array}$ & 2015 & $2: 18$ & $\begin{array}{l}\text { Youtube, app, web } \\
\text { del medio, Facebook }\end{array}$ & $\begin{array}{l}\text { Imageen } \\
\text { Tarraco }\end{array}$ & Cultura \\
\hline Ingeniería Romana - El circo & 2015 & $2: 16$ & $\begin{array}{l}\text { Youtube, app, web } \\
\text { del medio, Facebook }\end{array}$ & $\begin{array}{l}\text { Imageen } \\
\text { Tarraco }\end{array}$ & Cultura \\
\hline
\end{tabular}




\begin{tabular}{|c|c|c|c|c|c|}
\hline Vive Río. Heroínas & 2016 & $20^{\prime}$ aprox. & App & Vive Río & Deportes \\
\hline $\begin{array}{l}\text { Primer encierro de San } \\
\text { Fermín } 2016\end{array}$ & 2016 & $3: 04$ & $\begin{array}{l}\text { Youtube, web del } \\
\text { medio, Facebook }\end{array}$ & - & Espectáculo \\
\hline $\begin{array}{l}\text { Segundo encierro de San } \\
\text { Fermín } 2016\end{array}$ & 2016 & $0: 47$ & $\begin{array}{l}\text { Youtube, web del } \\
\text { medio, Facebook }\end{array}$ & - & Espectáculo \\
\hline $\begin{array}{l}\text { Tercer encierro de San } \\
\text { Fermín } 2016\end{array}$ & 2016 & $7: 29$ & $\begin{array}{l}\text { Youtube, web del } \\
\text { medio, Facebook }\end{array}$ & - & Espectáculo \\
\hline $\begin{array}{l}\text { Cuarto encierro de San } \\
\text { Fermín } 2016\end{array}$ & 2016 & $1: 55$ & $\begin{array}{l}\text { Youtube, web del } \\
\text { medio, Facebook }\end{array}$ & - & Espectáculo \\
\hline $\begin{array}{l}\text { Quinto encierro de San } \\
\text { Fermín } 2016\end{array}$ & 2016 & $1: 54$ & $\begin{array}{l}\text { Youtube, web del } \\
\text { medio, Facebook }\end{array}$ & - & Espectáculo \\
\hline $\begin{array}{l}\text { Sexto encierro de San Fermín } \\
2016\end{array}$ & 2016 & $1: 51$ & $\begin{array}{l}\text { Youtube, web del } \\
\text { medio, Facebook }\end{array}$ & - & Espectáculo \\
\hline $\begin{array}{l}\text { Séptimo encierro de San } \\
\text { Fermín } 2016\end{array}$ & 2016 & $1: 44$ & $\begin{array}{l}\text { Youtube, web del } \\
\text { medio, Facebook }\end{array}$ & - & Espectáculo \\
\hline $\begin{array}{l}\text { Octavo encierro de San } \\
\text { Fermín } 2016\end{array}$ & 2016 & $2: 16$ & $\begin{array}{l}\text { Youtube, web del } \\
\text { medio, Facebook }\end{array}$ & - & Espectáculo \\
\hline $\begin{array}{l}\text { Los espacios teatrales de } \\
\text { Almagro } 360^{\circ}\end{array}$ & 2017 & $0: 48$ & $\begin{array}{l}\text { Youtube, web del } \\
\text { medio, Facebook }\end{array}$ & - & Cultura \\
\hline Cyrano de Bergerac en $360^{\circ}$ & 2017 & $2: 14$ & $\begin{array}{l}\text { Youtube, app y web } \\
\text { del medio }\end{array}$ & $\begin{array}{l}\text { Escena } \\
360^{\circ}\end{array}$ & Cultura \\
\hline Escena $360^{\circ}$ : Alento' & 2017 & $3: 22$ & $\begin{array}{l}\text { Youtube, app, web } \\
\text { del medio, Facebook }\end{array}$ & $\begin{array}{l}\text { Escena } \\
360^{\circ}\end{array}$ & Cultura \\
\hline $\begin{array}{l}\text { Vive en } 360^{\circ} \text { y sonido } \\
\text { posicional una escena de } \\
\text { \#Misantropo de Molière }\end{array}$ & 2017 & $2: 20$ & $\begin{array}{l}\text { Youtube, app, web } \\
\text { del medio, Facebook }\end{array}$ & $\begin{array}{l}\text { Escena } \\
360^{\circ}\end{array}$ & Cultura \\
\hline $\begin{array}{l}\text { Vive en } 360^{\circ} \text { y sonido } \\
\text { posicional una escena de 'La } \\
\text { cocina' }\end{array}$ & 2017 & $3: 13^{\prime}$ & $\begin{array}{l}\text { Youtube, app y web } \\
\text { del medio }\end{array}$ & $\begin{array}{l}\text { Escena } \\
360^{\circ}\end{array}$ & Cultura \\
\hline Cervantes VR & 2017 & 12' aprox. & $\begin{array}{l}\text { YouTube, app y web } \\
\text { del medio }\end{array}$ & $\begin{array}{l}\text { Cervantes } \\
\text { VR }\end{array}$ & Espectáculo \\
\hline
\end{tabular}

Fuente: elaboración propia

Los porcentajes y frecuencias obtenidos tras el posterior tratamiento de los datos revelan un porcentaje más significativo de publicaciones durante 2016, situándose en un 47,4\% y reduciéndose hasta un 31,6\% en 2017, lo que refleja una cierta resistencia hacia una mayor consolidación y expansión del formato, tal y como refleja el Gráfico 1. 
Gráfico 1: Evolución de los proyectos inmersivos en vídeo en $360^{\circ}$ de Lab RTVE.es

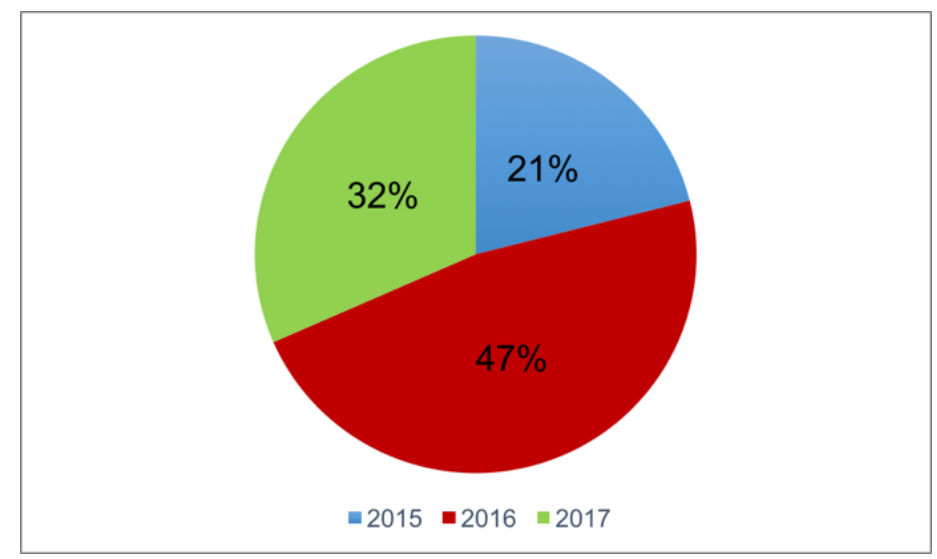

Fuente: elaboración propia

La duración de las piezas publicadas es breve, no superando los 5 minutos en el $84,2 \%$ de los casos analizados. Se recurre a más de dos plataformas de distribución en un $84,2 \%$ de ellos, siendo las más frecuentes YouTube, la web del medio y Facebook. En un 10,5\% se emplea sólo Youtube y la web del medio. El reportaje Vive Río: Heroínas es la excepción a esta práctica ya que no se distribuye a través de ninguna de las dos redes sociales citadas sino únicamente desde la web del medio y una app creada específicamente para su visualización. En un $52,6 \%$ se distribuyen a través de una app diseñada para su distribución, que es única en el caso de los trabajos Ingeniería Romana, Vive Rio: Heroinas y Cervantes V R.

Por el contrario, la app "Escena 360" comparte varios proyectos centrados en temáticas teatrales. En un $94,7 \%$ de los casos los temas escogidos se centran en aspectos asociados al ámbito de la cultura y/o del espectáculo, mientras que el 5,3\% restante lo hace en deportes. Respecto al uso de sobreimpresiones, que pueden evidenciar cierto artificio en la representación, no se emplean en un $68,4 \%$ de los trabajos. La excepción se concentra en dos de los primeros trabajos donde se añaden de un modo evidente: los reportajes Ingeniería Romana y Vive Rio: Heroinas, donde se entremezclan figuras e infografías, en el primer caso, y ventanas, cartelas, créditos y cortinillas, en el segundo.

$\mathrm{Al}$ análisis de contenido aporta también datos relativos al uso de determinados recursos propios de la narrativa inmersiva. En concreto, las referidas a la representación del espacio como la altura de la cámara, 
el punto de vista, el tratamiento del equipo y del personal de grabación, la continuidad entre escenas y el uso de sobreimpresiones (cartelas, rótulos, ventanas, títulos, botones de navegación, etc.). Junto a ellas, otras que hacen referencia a la participación del espectador dentro del relato: rol, modo de representación, interacciones y elementos para atraer su atención. Los resultados muestran que, en un 47,4\% de los casos, la altura de la cámara está situada a la de los ojos del espectador, mientras que en un $42,1 \%$ se trata de planos cenitales. En el resto, se combinan planos en los que la cámara coincide con la altura de los ojos del espectador con otros como cenitales (5,3\%), la cámara se eleva entre 50 y 100 centímetros sobre la altura de los ojos del espectador $(5,3 \%)$, o se entremezclan (5,3\%), tal y como muestra el Gráfico 2:

\section{Gráfico 2: Altura de la cámara en los proyectos en vídeo en $360^{\circ}$ de Lab RTVE.es}

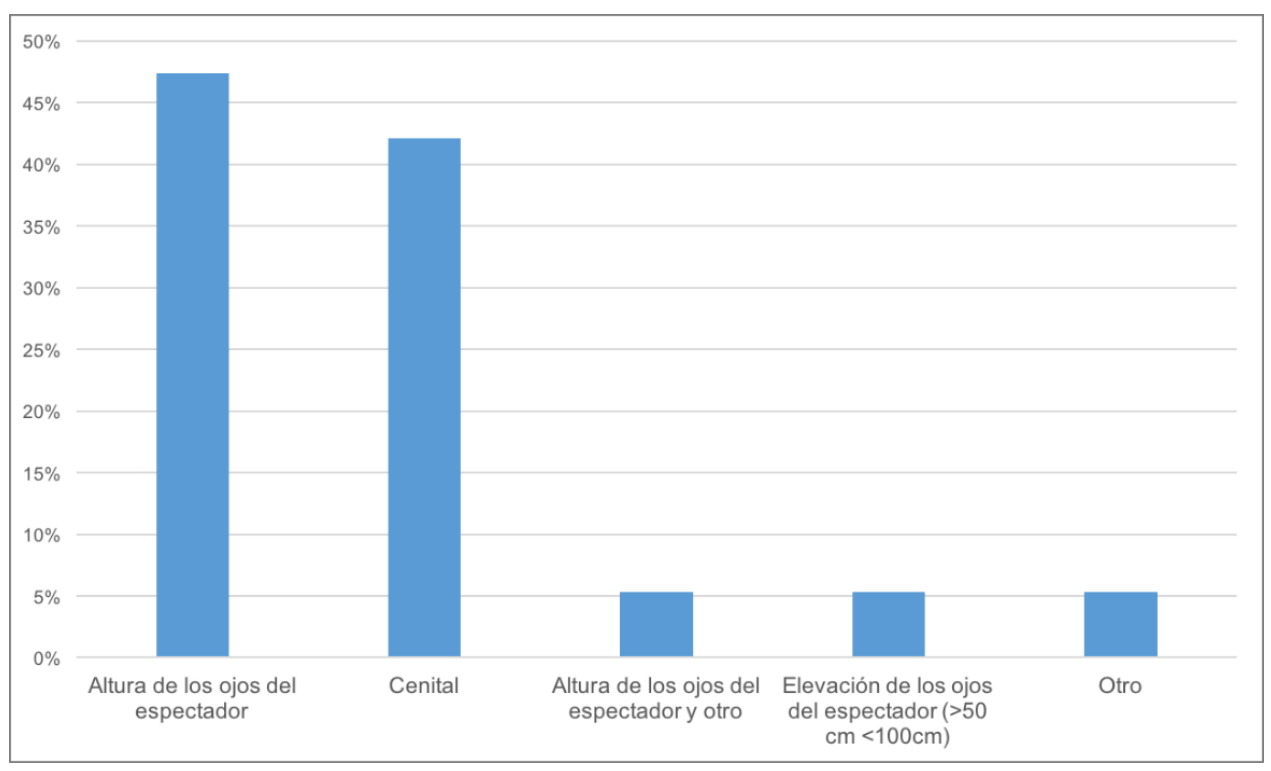

Fuente: elaboración propia

Respecto al punto de vista o focalización narrativa, es decir, dónde se sitúa la mirada del espectador, los resultados obtenidos muestran igual porcentaje en el uso de la focalización primaria o cámara subjetiva $(26,3 \%)$ y en el de la focalización secundaria (26,3\%). El empleo de la focalización "cero", que sitúa al espectador al margen de la narración se da en un $42,1 \%$ de los casos analizados, un porcentaje elevado que, de acuerdo con Domínguez (2013), aumenta la distancia del espectador hacia el relato. En el 5,3\% restante se combinan las tres técnicas. 
El uso del plano secuencia para establecer la continuidad prevalece, en un 78,9\% de los casos. Siguiendo a Casetti y Di Chio, este dato debe ser considerado de forma positiva ya que "el uso de un único plano secuencia transmite fluidez de movimiento por un espacio, lo que garantiza la temporalidad representada con la (supuestamente) real" (2007: 157). En el resto de trabajos, la unión de escenas se reparte por igual: corte $(5,3 \%)$, fundido a negro $(5,3 \%)$, cortinilla $(5,3 \%)$ y encadenado (5,3\%). En este sentido, cabe recordar estudios recientes que han comprobado que la transición por corte es la más adecuada para una coherencia máxima ya que es la menos evidente (Men et al., 2017: 286).

Finalmente, respecto al tratamiento del equipo y del personal de grabación durante el proceso de postproducción hay que señalar que, en todos los casos, se opta por eliminar al periodista o a la persona que graba la escena. La cámara se elimina totalmente de la escena en un $42,1 \%$ de los casos. En un 10,5\% de los casos se sustituyen por un elemento gráfico circular en la parte inferior de la escena $360^{\circ}$.

Las intervenciones del espectador como parte de la narración son escasas. En la mayoría de los casos adquiere un rol de espectador $(89,5 \%)$ frente al de participante (10,5\%). No obstante, se trata de una participación pasiva, donde no interviene realmente en el curso de la historia. Junto a estos datos, tampoco se representa la figura del espectador en ninguno de los proyectos, lo que, en caso contrario y de acuerdo con algunos autores, podría ayudar a generar la ilusión de estar dentro del acontecimiento (Weil y De-la-Peña, 2008; Slater et al., 2010: 1; Banakou, Groten y Slater, 2013; Decock et al., 2014).

\subsection{Resultados de la entrevista en profundidad}

La innovación a través de la búsqueda de nuevas narrativas y formatos transmedia se ha convertido en una de las prioridades del ente público RTVE en los últimos años con la creación de diferentes áreas orientadas a este fin. Entre ellas, destaca la labor que ha desarrollado el Laboratorio de Innovación, Lab RTVE.es, que desde su nacimiento en 2011 se centra en la exploración y el desarrollo de nuevas narrativas audiovisuales. Junto a otros nuevos formatos, como el webdoc y los 
interactivos, las narrativas inmersivas en vídeo $360^{\circ}$ han cobrado un fuerte impulso dentro de esta área.

Desde las primeras publicaciones en este formato en 2015 la evolución de estos trabajos se ha ido orientando hacia temas culturales, centrados especialmente en espacios teatrales, que Hernanz define como artes escénicas inmersivas. Además de Youtube y Facebook, para la distribución de estos trabajos se ha desarrollado una app específica creada para sistemas iOS y Android, Escena 360 ${ }^{\circ}$ que aúna estos proyectos: La Cocina, Misántropo, Alento, Cyrano de Bergerac, publicados en 2017 y un ensayo del Coro y otro de la orquesta del Teatro Real, en 2018 (Hernanz, 2018).

Las narrativas inmersivas en vídeo $360^{\circ}$ comparten unos rasgos singulares que se deben tener en cuenta durante el proceso de creación. Siguiendo a Hernanz, es más importante el guion de imagen que el guion escrito, dado que plantea dificultades distintas a las que se pueden dar en otro guion de vídeo tradicional. Entre ellas, el uso de determinados planos, que en vídeo $360^{\circ}$ está limitado y deben ser largos:

No hay primeros planos en vídeo en $360^{\circ}$. Nunca vas a tener un primer plano como con una cámara tradicional en la que solamente quieres ver los ojos [...] El montaje también cambia. Los planos en vídeo $360^{\circ}$ tienen que tener treinta segundos como mínimo y dejar que el usuario descubra el entorno en el que está antes de hacer una transición de plano (Hernanz, 2016).

Esta última afirmación coincide con los resultados hallados en el análisis donde se ha optado por planos secuencia en un $82,8 \%$ de los casos. Esto permite que el espectador pueda recorrer la totalidad del escenario al tiempo que se desarrolla la acción representada. Sobre la duración de los vídeos, recomienda "hacer vídeos cortos, de no más de cinco minutos" (2016), lo cual coincide también con dichos resultados. Cuando se ha trabajado con tiempos más largos, como ocurre en Ingeniería Romana, Vive Río: Heroinas o Cervantes $V \mathrm{R}$, se han dividido en piezas breves que el espectador puede visualizar en momentos diferentes.

Junto a estas consideraciones, otra de las diferencias encontradas es la dificultad para atraer la atención del espectador hacia un área concreta 
de la escena ya que es libre de recorrerla bien con el dedo (modo táctil) bien con la mirada (con gafas de realidad virtual):

En un guion de cualquier rodaje en $360^{\circ}$ no se puede estar seguro de que el usuario va a tener la experiencia deseada. Cada experiencia es única, porque a lo mejor pones un rótulo ahí, pero él mira para allá y él se pierde esa información (Hernanz, 2016).

En este sentido, aunque destaca la importancia de la iluminación y del sonido como vehículos para lograr una experiencia más inmersiva del usuario en la narración (Hernanz, 2018), en los resultados obtenidos en el análisis el uso de la luz y del sonido no se utiliza a este fin, en la mayoría de los casos. La única excepción se advierte en Cervantes V $R$ que, en la escena inicial -que hace las veces de menú de navegación-, mantiene la iluminación sobre los personajes y deja el resto de escenario bajo un fondo negro.

Por último, Hernanz incide en la importancia de definir muy bien el rol del espectador en la narración, si bien, teniendo en cuenta las limitaciones propias del vídeo $360^{\circ}$ para generar una interactividad real:

Para que el usuario disfrute de la experiencia inmersiva tiene que entender perfectamente qué se le pide, qué se le exige y por qué hemos situado la cámara en ese determinado lugar (Hernanz, 2018).

Respecto al descenso de las producciones en el último año analizado señala la relación que existe con la "capacidad de monetizar el producto y el coste de la producción" ya que "el coste de estas narrativas en muy elevado", y la necesidad de hacer uso de las gafas de realidad virtual, que "aunque ya no son algo excepcional, no hay mucha gente en España que se las haya puesto” (Hernanz, 2018).

\subsection{Resultados del estudio de caso: Vive Río: Heroínas}

Ligado a la estrategia de innovación periodística y audiovisual Vive Río: Heroinas es un reportaje realizado en vídeo $360^{\circ}$ que se publica el 20 de julio de 2016. Su finalidad es situar al espectador en el centro de una jornada de entrenamiento al lado de las deportistas que participaron en cinco modalidades deportivas femeninas con opción a medalla en las Olimpiadas de Río de Janeiro en 2016: gimnasia rítmica, aguas bravas, natación sincronizada, rugby y doma clásica. Parte del trabajo se 
externaliza a través de la productora especializada en experiencias inmersivas InMediaStudio. Esta empresa se encarga del desarrollo del proyecto, así como de la app para su distribución, Vive Río, a través de los sistemas operativos Android e iOS. Hernanz entiende esta colaboración como una inversión con retorno ya que permite aprovechar el conocimiento adquirido y trasladarlo de vuelta a su departamento:

Yo lo que pretendo es que el conocimiento se quede en casa. Y si necesitamos de sus recursos porque tienen la capacidad de coser los planos, me parece genial, pero yo necesito quedarme el knowhow [...] Todo el conocimiento que puede venir es bienvenido (Hernanz, 2016).

La fase de grabación de los vídeos se realiza en cinco jornadas diferentes que tienen lugar durante los meses de mayo y junio. Para algunas de estas sesiones es necesario trasladar a los equipos de grabación fuera de Madrid, ya que la sede de entrenamiento de las deportistas de aguas bravas y natación sincronizada se encuentran en Cataluña. Cada jornada tiene una duración aproximada de doce horas (sin contar traslados). La fase del proceso de postproducción de los vídeos se prolonga durante un mes y medio, aproximadamente.

Aunque el análisis de la tecnología empleada para la creación de este tipo de piezas queda fuera de los objetivos de este trabajo, se ha considerado la importancia de introducir en este apartado los principales recursos, humanos y técnicos, empleados durante el proceso de producción y que se resumen en la Tabla 2. Aunque su interpretación no debe ser considerada de forma inferencial, dada la fase de desarrollo y evolución en la que se encuentra actualmente la tecnología de vídeo $360^{\circ}$, ofrece una aproximación a la complejidad y a la especialización requerida para la creación de este tipo de contenidos. 
Tabla 2: Equipo técnico empleado en la producción del reportaje Vive Río: Heroínas

\begin{tabular}{|c|c|c|c|c|c|c|c|}
\hline \multicolumn{3}{|c|}{ Fase de grabación } & \multicolumn{5}{|c|}{ Fase de postproducción } \\
\hline Personal & \multicolumn{2}{|c|}{$\begin{array}{l}\text { Equipo de } \\
\text { grabación }\end{array}$} & Personal & \multicolumn{2}{|c|}{ Equipo de hardware } & \multicolumn{2}{|c|}{ Software de edición } \\
\hline $\begin{array}{l}\text { Realizador } \\
\text { de cámara } \\
360^{\circ}\end{array}$ & \multirow[t]{3}{*}{$\begin{array}{l}\text { Planos } \\
\text { interiores }\end{array}$} & $\begin{array}{l}\text { Rig } \text { Sony } \\
\text { alfa } 7 \quad(4 \\
\text { cámaras) }\end{array}$ & $\begin{array}{l}1 \text { Editor / } \\
\text { VFX }\end{array}$ & \multirow[t]{3}{*}{ Equipo 1} & $\begin{array}{l}\text { CPU Intel } \\
\text { Core } \\
\text { i } 74790 \mathrm{~K}\end{array}$ & $\begin{array}{l}\text { Stitching } \\
\text { de los } \\
\text { vídeos }\end{array}$ & $\begin{array}{l}\text { Autopano } \\
\text { Video } \\
\text { Stitching }\end{array}$ \\
\hline $\begin{array}{l}\text { Operador } \\
\text { de cámara } \\
360^{\circ}\end{array}$ & & $\begin{array}{l}\text { Rig } \\
\text { GoPro } \\
4+\text { (de } 3 \text { a } \\
6 \text { cámaras } \\
\text { por rig) }\end{array}$ & $\begin{array}{l}1 \mathrm{VFX} / \\
\text { Etalonaje }\end{array}$ & & $\begin{array}{l}3.60 \mathrm{GHz} \\
16 \mathrm{~GB}\end{array}$ & $\begin{array}{l}\text { Postproduc } \\
\text { ción }\end{array}$ & $\begin{array}{l}\text { Adobe } \\
\text { Photoshop }\end{array}$ \\
\hline $\begin{array}{l}\text { Operador } \\
\text { de } \\
\text { producción }\end{array}$ & & $\begin{array}{l}\text { Kodak } \\
\text { Pixpro } \\
\text { Dúo } \\
\text { sp360 }\end{array}$ & $2 \mathrm{VFX}$ & & $\begin{array}{l}\text { GPU } \\
\text { Nvidia } \\
\text { GTX } 770\end{array}$ & & $\begin{array}{l}\text { Adobe After } \\
\text { Effects }\end{array}$ \\
\hline $\begin{array}{l}\text { Técnico de } \\
\text { Imagen } \\
\text { Digital }\end{array}$ & \multirow[t]{3}{*}{$\begin{array}{l}\text { Planos } \\
\text { exteriores }\end{array}$} & $\begin{array}{l}\text { Rig } \\
\text { GoPro } \\
4+\text { (de } 3 \text { a } \\
6 \text { cámaras } \\
\text { por rig) }\end{array}$ & $\begin{array}{l}\text { Responsable } \\
\text { 3D Artist }\end{array}$ & \multirow[t]{3}{*}{ Equipo 2} & $\begin{array}{l}\text { CPU Intel } \\
\text { Core i } 76700\end{array}$ & $\begin{array}{l}\text { Software } \\
\text { de audio }\end{array}$ & Tools HD12 \\
\hline $\begin{array}{l}\text { Ayudante } \\
\text { de cámara } \\
360^{\circ}\end{array}$ & & $\begin{array}{l}\text { Rig } \\
\text { Freedom } \\
360 \\
\text { Brodcaste } \\
\text { 3x }\end{array}$ & 3 3D Artis & & $\begin{array}{l}4.00 \mathrm{GHz} \\
32 \mathrm{~GB}\end{array}$ & & Two Big Ears \\
\hline $\begin{array}{l}\text { Técnico de } \\
\text { sonido } \\
360^{\circ}\end{array}$ & & $\begin{array}{l}\text { Kodak } \\
\text { Pixpro } \\
\text { Dúo } \\
\text { sp360 }\end{array}$ & $\begin{array}{l}\text { Responsable } \\
\text { de Diseño }\end{array}$ & & $\begin{array}{l}\text { GPU } \\
\text { Nvidia } \\
\text { GTX } 960\end{array}$ & $\begin{array}{l}\text { Desarrollo } \\
\text { aplicación }\end{array}$ & UNITY \\
\hline \multirow[t]{3}{*}{ Guionista } & $\begin{array}{l}\text { Escenas } \\
\text { acuáticas }\end{array}$ & $\begin{array}{l}\text { Rig Abyss } \\
(6 \\
\text { cámaras } \\
\text { GoPro } \\
4+)\end{array}$ & $\begin{array}{l}3 \\
\text { Diseñadores }\end{array}$ & \multirow[t]{3}{*}{ Equipo 3} & $\begin{array}{l}\text { CPU Intel } \\
\text { Core } \\
\text { i } 74930 \mathrm{~K}\end{array}$ & $\begin{array}{l}\text { Modelado } \\
\text { 3D }\end{array}$ & $\begin{array}{l}\text { 3D Studio } \\
\text { MAX }\end{array}$ \\
\hline & $\begin{array}{l}\text { Planos } \\
\text { aéreos }\end{array}$ & $\begin{array}{l}\text { Rig para } \\
\text { Drone }(7 \\
\text { cámaras } \\
\text { GoPro } \\
4+)\end{array}$ & & & $\begin{array}{l}3.70 \mathrm{GHz} \\
48 \mathrm{~GB}\end{array}$ & & Maya \\
\hline & & & & & $\begin{array}{l}\text { GPU AMD } \\
\text { Firepro } \\
\text { W9100 }\end{array}$ & & \\
\hline
\end{tabular}

Fuente: elaboración propia

La app ofrece dos modalidades para visualizar las cinco modalidades deportivas que se muestran a través de los vídeos: desde la pantalla del 
dispositivo móvil o por medio de unas gafas de realidad virtual. Para poder verlos, además, es necesario descargarlos uno a uno. Al inicio del reportaje el espectador accede a un menú de navegación esférico con las distintas modalidades deportivas que puede seleccionar pulsando con el dedo (modo táctil) o fijando la mirada (si accede con las gafas). Durante la fase de postproducción se han unido las imágenes e introducido diferentes elementos entre los que destacan dos: el audio y los elementos gráficos. El primero de ellos aporta una información decisiva. Así, cada una de las piezas se introduce con la voz en off de Paloma del Río, comentarista de las últimas catorce ediciones de las Olimpiadas en RTVE y fácilmente reconocible por el espectador. Por otro lado, cada pieza de vídeo está conducida por la voz en off de cada una de las deportistas, obtenida a través de una entrevista previa y que ofrece el testimonio en primera persona de cada una de ellas. Además, se ha añadido el sonido ambiente, como el agua o el ruido de las cintas de rítmica al golpear con el tapiz, que contribuye a que el espectador dirija su atención hacia ese punto concreto de la acción.

Figura 2: Fotograma de la modalidad de gimnasia rítmica del proyecto Vive Río: Heroínas

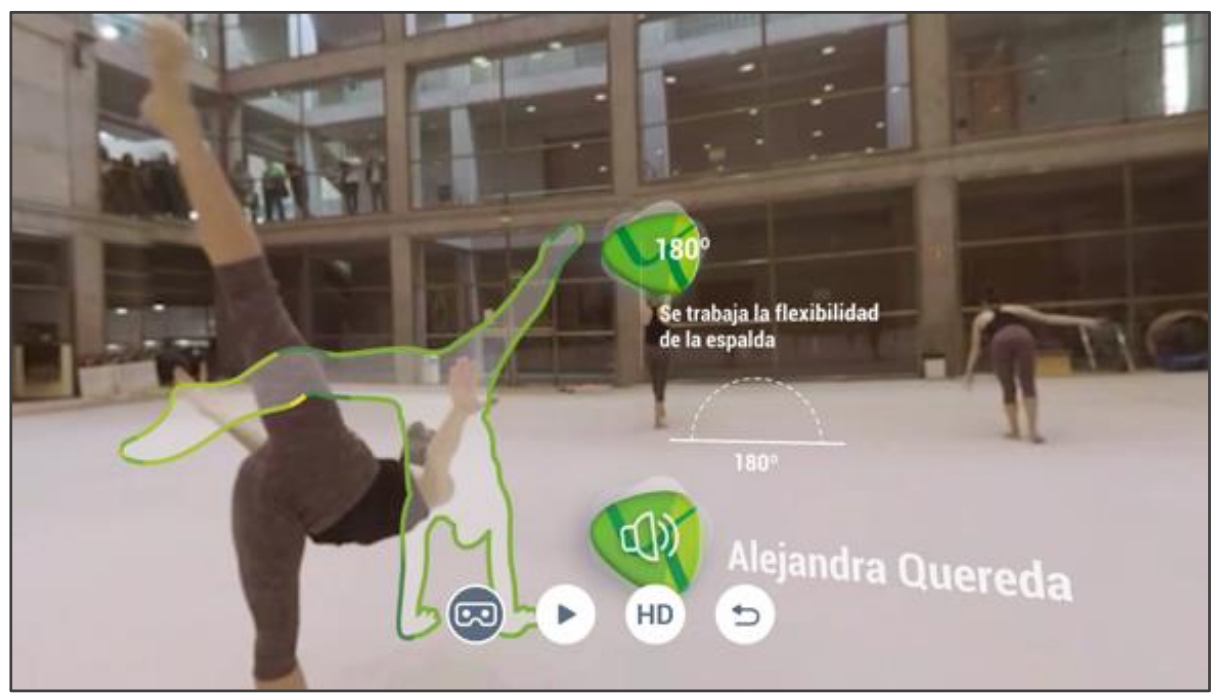

Fuente: Captura de pantalla de la app "Vive Río"

Como elementos a mejorar se advierte del empleo excesivo de elementos gráficos que, de acuerdo con algunos autores, añaden un componente de artificiosidad (Domínguez, 2013, Lombard y Ditton, 1997) y, pueden, por tanto, romper la sensación del espectador de encontrarse en un escenario real. En determinados momentos, como se advierte en la Figura 2, se utilizan botones de navegación, botones 
de interacción, títulos de crédito, gráficos y tablas con datos e información adicional. A ello se añade el uso de cortinillas de transición, diferentes según la modalidad deportiva.

Por último, Hernanz señala la aparición de cierto malestar o mareo al visualizar los vídeos como uno de los factores que añadieron dificultad al proyecto (2018). Se trata de un efecto ocasional que se da al visualizar este tipo de contenidos a través de unas gafas de realidad virtual (Lelyveld, 2015: 13). En este proyecto, en la modalidad de aguas bravas se colocó la cámara en un kayak lo que generaba mareo cuando se visionaba en unas gafas de realidad virtual. Para reducir este efecto se cambió el norte de la escena, comenzando la secuencia de cara a la deportista.

\section{Conclusiones}

Los proyectos inmersivos en vídeo $360^{\circ}$ se han consolidado estos últimos años como uno de los ejes del proceso de innovación que el ente público RTVE está haciendo en su labor de búsqueda y de adopción de nuevos formatos y narrativas. A través del impulso iniciado por el Lab RTVE.es, este formato ha encontrado un espacio idóneo para su aprendizaje y conocimiento que en otras áreas de la radiodifusora no resultarían viables debido a la novedad, complejidad e inversión que implica, tanto en lo relativo a su producción como a la tecnología y a la especialización requerida. Al mismo tiempo, la propia vocación de servicio público constituye un escaparate y una guía de referencia que pueden ser aprovechados por otros medios periodísticos que, aun cuando no tienen tantos recursos para invertir y experimentar a una escala similar, quieren iniciarse en producciones de menor coste y aprovechar las ventajas que ofrece este formato.

La tecnología de vídeo $360^{\circ}$ ha evolucionado especialmente en estos últimos cinco años a través de unos equipos más sencillos que han abaratado el coste de producción y permitido su adopción para crear proyectos periodísticos. Aunque no se puede considerar de forma absoluta, dado el corto período analizado, los 19 trabajos de estas características publicados por el Lab RTVE.es entre 2015 y 2017 certifican cierto interés por este tipo de iniciativas. Aun así, el descenso de un $15,8 \%$ en la producción de nuevos proyectos publicados en el 
último año impide confirmar una tendencia hacia su consolidación plena.

Los trabajos aquí analizados, si bien parten de una vocación periodística, se centran en temas culturales y de entretenimiento, un apunte que, en este caso, y según aclara Hernanz, viene impuesto por el propio organigrama del área. Esto hace que se echen en falta otro tipo de temáticas que pueden ser aprovechadas por las peculiaridades de este formato, entre ellas, las centradas en deportes, educación, ciencia o turismo.

En general, se trata de piezas breves, que no superan los cinco minutos de duración, una característica básica para mantener la atención del espectador y evitar algunas sensaciones molestas -malestar o mareoque, en ocasiones, genera la visualización de estos contenidos a través de las gafas de realidad virtual. La duración también se debe tener en cuenta ya que se distribuye principalmente por las redes sociales YouTube y/o Facebook, si bien también la web del medio como forma tradicional puede ser una vía importante para dar a conocer los trabajos. No obstante, estas dos plataformas citadas permiten su visualización tanto a través de la pantalla del móvil como de unas gafas de realidad virtual (opcional) de un modo directo, fácil y sin necesidad de descargar previamente los contenidos, como si ocurre cuando se trata de apps. En este sentido, aunque destaca el desarrollo de apps específicas para su distribución a través de dispositivos móviles, su uso no aporta un beneficio claro ya que que añaden un mayor coste, dificultan el proceso de producción y ralentizan su visualización por los tiempos de descarga.

Por último, dentro de las características narrativas inmersivas empleadas en este tipo de trabajos se advierte aún un uso experimental, mejorable con la adopción de algunos recursos. Entre ellos, reducir el empleo de elementos que evidencien la mediación como las sobreimpresiones y potenciar otros como el sonido ambiente; reducir o eliminar planos cenitales que se dan en un porcentaje bastante elevado $(42,1 \%)$ y hace que aumente la distancia entre el espectador y la historia; y potenciar el empleo de la focalización en primera persona en combinación con elementos interactivos. Cabe señalar que, aunque hay proyectos en los que se puede navegar por la acción a través de botones dispuestos en la pantalla, no constituyen una vivencia narrativa 
dentro de ésta (Domínguez, 2013: 271). En este sentido, añadir algunos recursos como la simulación de acción a través del movimiento de la cámara que se advierte en el reportaje Vive Río: Heroinas, puede contribuir a ello.

\section{Bibliografía}

Banakou, D., Groten, R. \& Slater, M. (2013). Illusory ownership of a virtual child body causes overestimation of object sizes and implicit attitude changes. In Proceedings of the National Academy of Sciences of the United States of America, 110(31), 12846-12851: https://goo.gl/KzEfYo

Benítez, M.J. y Herrera-Damas, S. (2018). "El reportaje inmersivo en vídeo $360^{\circ}$ : diseño de un modelo de análisis". El profesional de la información, 27(1), pp. 149-161. DOI: 10.3145/epi.2018.ene.14

Casetti, F. \& Di Chio, F. (2007). Cómo analizar un film. Barcelona, Paidós.

Decock, J., Van-Looy, J., Bleumers, L. \& Bekaert, P. (2014). “The pleasure of being (there?): An explorative study into the effects of presence and identication on the enjoyment of an interactive theatrical performance using omnidirectional video". Ai \& society, 29(4), pp. 449-459. DOI: 10.1007/s00146-013-0487-6

Del Campo Cañizares, E. y Zaragoza Fuster, T. (2017). Medialabs españoles. Un análisis de sus formatos narrativos. En Canavilhas, J. y Rodrigues, C. (orgs.), Jornalismo móvel, Linguagem, géneros e modelos de negócio (153-174). Beira: Editora LabCom.IFP.

De la Peña, N., Weil, P., Llobera, J., Spanlang, B., Friedman, D., Sánchez Vives, M. y Slater, M. (2010). Immersive Journalism: immersive virtual reality for the first-person experience of news. Presence: Teleoperators and virtual enviroments, 19(4), 291-301.

Domínguez, E. (2013). Periodismo inmersivo: La influencia de la realidad virtual y del videojuego en los contenidos informativos. Barcelona: Editorial UOC.

Domínguez, E. (2015). Periodismo inmersivo o cómo la realidad virtual y el videojuego influyen en la interfaz e interactividad del 
relato de actualidad. El Profesional De La Información, 24(4), 413423. doi: 10.3145/epi.2015.jul.08

Doyle, P., Gelman, M. y Gill, S. (2016). Viewing the future? Virtual reality in journalism. Recuperado en https://goo.gl/ZJX4UG

European Broadcasting Union (2017). Virtual reality: How are public broadcasters using it? Recuperado en https://goo.gl/ewgtyX

Frasca, G. (2007). Play the message. Play, Game and Videogame Rhetoric. Copenhagen, IT University of Copenhagen.

García-Avilés, J.A. (2018). Resultados de la innovación en los laboratorios de medios: el caso de el confidencial.LAB. El profesional de la información, 27(2), 359-366.

Hardee, G.M. y McMahan, R. (2017). FIJI: a framework for the immersion-journalism intersection. Frontiers in ICT, 4. doi:10.3389/ fict.2017.00021

Kapp, K. (2012). The gamification of learning and instruction: game-based methods and strategies for training and education. San Francisco: Pfeifer.

Lelyveld, P. (2015). Virtual Reality Primer with an Emphasis on Camera-Captured VR. Motion Imaging Journal SMPTE, 124(6), 78-85. DOI: 10.5594/j18599

Lombard, M. \& Ditton, T. (1997). At the Heart of It All: The Concept of Presence. Journal of Computer-Mediated Communication, $3(2)$.

Longhi, R.R. (2017). Immersive narratives in web journalism. Between interfaces and virtual reality. Estudos em Comunicação, (25), pp.13-22. doi:10.20287/ec. n25.v1. a02

Men, L., Bryan-Kinns, N., Hassard, A.S. \& Ma, Z. (2017). The impact of transitions on user experience in virtual reality. In Proc. IEEE Virtual Reality, pp. 285-286, 2017.

Morales, L. F. (2012). Estructura y sentido de la noticia televisiva: parámetros para la construcción y el análisis del mensaje en el entorno audiovisual. Estudios sobre el Mensaje Periodístico, 18 (2), pp. 805-821. 
Nash, K. (2015). Simulation games, popular factual media and civic engagement: an audience study of Asylum Exit Australia. Media, Culture \& Society, 1-13. doi:10.1177/0163443715584103

Pérez-Seijo, S., López-García, X. y Campos-Freire, F. (2018). La aplicación de las narrativas inmersivas en los reportajes: estudio de caso del diario español El País. En: González-Esteban J.L. y García-Avilés, J.A. (coords.), Mediamorfosis: Radiografía de la innovación en periodismo. Sociedad Española de Periodística, pp. $61-78$.

Pérez-Seijo, S. y Benítez de Gracia, M.J. (2018). Las narrativas inmersivas como valor de innovación en las radiotelevisiones públicas europeas. En Pérez-Seijo, S., Rodríguez-Castro, M. y Túñez-López, M. (Eds.) (2018). Debates sobre valores e indicadores del servicio audiovisual público en Europa (pp. 121137). Cuadernos Artesanos de Comunicación, cac142. La Laguna (Tenerife): Latina. DOI: 10.4185/cac142.

Sádaba, C. y Salaverría, R. (2016). Los 'labs' de medios en España: modelos y tendencias. En Casero-Ripollés, A. (ed), Periodismo y democracia en el entorno digital (149-164). Salamanca: SEP.

Slater, M., Spalang, B., Sánchez-Vives, M.V. \& Blanke, O. (2010). First Person Experience of Body Transfer in Virtual Reality. PLoS ONE, 5(55), e10564: DOI: 10.1371/journal.pone.0010564

Tse, A., Jennett, C., Moore, J., Watson, Z., Rigby, J. y Cox, A.L. (2017). Was I There? Impact of Platform and Headphones on 360 Video Immersion. En actas del CHI Conference Extended Abstracts on Human Factors in Computing Systems. doi:10.1145/3027063.3053225

Vázquez-Herrero, J. y López-García, X. (2016). La gamificación en el periodismo a través del documental interactivo: estudio comparativo de Pirate Fishing, Réfugiés y Montelab. XXI Congreso Internacional SEP, Madrid (España).

Weil, P. \& De la Peña, N. (2008). Avatar mediated cinema. In International Conference on Advances in Computer Entertainment Technology, 352, 209-212: DOI: $10.1145 / 1501750.1501799$ 
Wimmer, R. \& Dominick, J. (1996). La investigación cientifica de los medios de comunicación: una introducción a sus métodos. Barcelona: Bosch.

\section{OTROS DOCUMENTOS}

\section{Entrevistas}

Hernanz, M. (2016, abril). Entrevista a Miriam Hernanz realizada por Benítez. M.J. Madrid.

Hernanz, M. (2018, mayo). Entrevista a Miriam Hernanz realizada por Benítez. M.J. Madrid.

\section{Páginas web}

Hernanz, M. (2017). Open Words - RTVE Lab y las nuevas narrativas en Periodismo [vídeo]. Recuperado el 10 de septiembre de 2018, de https://www.youtube.com/watch?v=CSVO_UvaOqI

\section{Reconocimientos de la investigación}

La autora Sara Pérez-Seijo es beneficiaria del programa de Formación del Profesorado Universitario (FPU16/06156) financiado por el Ministerio de Educación, Cultura y Deporte (Gobierno de España). 



\title{
Reflexiones en torno a los desafíos regulatorios de la nueva Directiva de Servicios de Comunicación Audiovisual
}

\author{
Laura Caballero Trenado \\ Universidad Internacional de La Rioja
}

PARA CITAR: Caballero Trenado, L. (2018). Reflexiones en torno a los desafíos regulatorios de la nueva Directiva de Servicios de Comunicación Audiovisual. En Rodríguez-Castro, M., Pérez-Seijo, S. y Campos-Freire, F. (Eds.). La TV Pública en Europa: Innovación, Retos y Tendencias (49-72). Cuadernos Artesanos de Comunicación, cac 146. La Laguna (Tenerife): Latina. DOI: 10.4185/cac146.

\section{Resumen}

En el marco de las diversas iniciativas que se han planteado en torno al Mercado Único Digital, la Comisión Europea ha propuesto una nueva Directiva de Servicios de Comunicación Audiovisual cuyo reto principal es cohonestar la protección de los intereses de los broadcaster tradicionales y de los nuevos operadores, por cuanto todos ellos deben ser compatibles. La elección de este concreto Instrumento normativo para posibilitar este propósito no es baladí, ya que permite un margen a los Estados Miembros. Un objetivo difícil, sí, por cuanto el servicio audiovisual público se debe a una audiencia amplia, lo que no siempre coincide con un target alto que, en cambio, sí ofrece rentabilidad económica. Pero una oportunidad única de dotar a la lógica económica que se presupone al sector audiovisual de una rentabilidad social. Y ello porque es un hecho que el consumo de contenidos audiovisuales ha cambiado (esta transformación es evidente especialmente en la 
televisión lineal) Ante este nuevo panorama, los motores del negocio de la televisión -contenidos, publicidad y audiencias (telespectadores/abonados) - se verán abocados a una redefinición de sus modelos respectivos ante el nuevo ecosistema digital. En esta Comunicación se abordan los desafíos regulatorios que plantea la nueva Directiva europea y su impacto en el concepto de servicio audiovisual público.

Palabras clave: Directiva de Servicios de Comunicación Audiovisual, servicio audiovisual público, ecosistema digital, Principio del País de Origen, plataformas de distribución de vídeos

\section{Introducción}

A finales de 2018 el conjunto de EE.MM. de la UE votará la nueva Directiva de Servicios de Comunicación Audiovisual (en adelante, DSCA II) que sustituirá a la anterior (2010/13/UE del Parlamento Europeo y del Consejo, de 10 de marzo de 2010).

La propuesta de Directiva, aprobada el 25 de mayo de 2016, es una iniciativa de la Comisión Europea y se enmarca en un conjunto de iniciativas que pretenden fortalecer el Mercado Único Digital.

El sector audiovisual, en general, y la televisión pública, en particular, precisan de un nuevo entorno regulatorio que ofrezca soluciones y otorgue seguridad jurídica a todos los operadores audiovisuales que conforman el nuevo ecosistema digital.

En efecto, esta medida trata de cohonestar los intereses de todos los operadores audiovisuales, lo que pasa por trasladar obligaciones que hasta ahora recaían únicamente en los radiodifusores tradicionales a las plataformas de servicios en línea, como la cuota de contenidos europeos.

En definitiva, el reto es adaptar la regulación a la nueva realidad que se ha impuesto en el mercado audiovisual, conformado actualmente por unas audiencias que cada vez consumen más contenidos a través de Internet. 
Abundando en lo anterior, a su vez, hay que tener en cuenta que una parte cada vez más grande de estos consumidores son, a su vez, emisores de contenidos vía streaming, una tecnología en auge.

El primer marco de normas comunes para la regulación europea de la radiodifusión televisiva lo encontramos en la Directiva de Televisión sin Fronteras de 1989. En 2010, esta normativa y sus posteriores enmiendas de 1997 y 2007 se refundieron en un único texto, la Directiva de Servicios de Comunicación Audiovisual, que en la actualidad es la piedra angular de la regulación de los medios de comunicación de la $\mathrm{UE}^{10}$.

Ahora, el objetivo de la UE es aplicar a las plataformas online reglas similares a las que ya regulan los 5.141 canales de televisión que existen en la Unión y lograr así un equilibrio entre la competitividad y la protección del consumidor. Por eso, se prevé introducir flexibilidad en aquellos casos en los que ya no están justificadas las restricciones aplicables únicamente a la televisión, fomentar las películas europeas, proteger a los menores y hacer frente al discurso del odio con más eficacia $^{11 .}$

El camino por el que ha transitado la elaboración del nuevo Instrumento normativo ha sido proceloso, ya que se han presentado más de 1.400 enmiendas, pero necesario, por cuanto urge dar respuesta a numerosos desafíos jurídicos.

En concreto, los cambios que, previsiblemente, comportará la nueva Directiva se aglutinan en torno a las cuestiones siguientes: país de origen, comunicaciones comerciales, protección del menor, prohibición del discurso del odio, promoción de obras europeas, plataformas de distribución de vídeos, accesibilidad, reguladores audiovisuales, así como la formalización del Grupo de Entidades Reguladoras Europeas para los Servicios de Comunicación Audiovisual.

\footnotetext{
${ }^{10}$ Vid. Panorama audiovisual (2017). Nueva Directiva europea del audiovisual ¿esperanza o amenaza? Artículo online. Panorama audiovisual. Recuperado el 10 de junio de 2018, de https://www.panoramaaudiovisual.com/2017/05/25/nuevadirectiva-europea-del-audiovisual-esperanza-o-amenaza/.

${ }^{11}$ Ibidem.
} 
Un vector sutura transversalmente los cambios en torno a estos puntos que se proponen en la nueva Directiva: el concepto de servicio audiovisual público. Volveremos más adelante sobre esta cuestión.

Interesa ahora analizar cuáles son los desafíos regulatorios que se presentan con incidencia en el sector audiovisual europeo y en qué se concretan los cambios que previsiblemente introducirá la DSCA II.

\section{La propuesta de nueva Directiva: desafíos a los que debe dar respuesta}

El objetivo general de la propuesta es lograr un equilibrio entre la competitividad y la protección del consumidor. En el marco del Mercado Único Digital, la Comisión Europea ha trazado una hoja de ruta muy ambiciosa para propiciar la reforma de leyes anticuadas y ambiguas que regulan las telecomunicaciones, los derechos de autor, la protección de datos o la aplicación de la ley de competencia.

El Instrumento normativo elegido por el legislador europeo para regular el sector audiovisual conformado por una amalgama de operadores audiovisuales -que va desde los broadcasters tradicionales a las diferentes plataformas de Video On Demand ( $V o D)$ - es una Directiva.

La elección del citado Instrumento es acertada, por cuanto su flexibilidad contribuye a reordenar un sector que es cambiante, por ejemplo, al suavizar las restricciones aplicables hasta ahora a la televisión y que ya no están justificadas.

Además, la nueva Directiva de Servicios de Comunicación Audiovisual para la UE tiene como objetivo general asegurar la integridad del mercado, es decir, lograr un equilibrio entre el fomento de la competitividad y la protección del usuario.

La justificación de ambos objetivos se plasma en los cuarenta y dos considerandos que preceden al corpus legislativo, que se estructura en torno a once capítulos. En total, la propuesta está formada por 33 artículos (el último es una especie de "cláusula de cierre" que delega en el legislador europeo la potestad de supervisión y aplicación de la Norma, así como la fijación del periodo máximo de implementación por parte de los EE.MM.). 
En línea con otras directivas, se trata de un texto breve que responde a la naturaleza de este concreto Instrumento normativo, concebido para obligar a los EE.MM. a alcanzar un resultado, pero dejándoles libertad tanto de forma como de medios para llevar a cabo su adopción.

Entre los desafíos concretos a los que debe ofrecer respuesta, pueden señalarse los siguientes: fomentar las películas europeas (la Directiva establece unas cuotas que se sitúan en la horquilla del 20 al 30 por ciento para las producciones europeas en las principales plataformas de servicios a la carta), proteger a los menores, dar una respuesta más eficaz a los discursos de odio e introducir limitaciones de los contenidos publicitarios en la televisión lineal y las plataformas de VoD.

\section{Cambios más relevantes}

\subsection{El Principio del País de Origen}

El Principio del País de Origen (PPO) es uno de los ejes centrales de la propuesta de Directiva; es clave en un mercado único y para la distribución de contenidos transfronterizos. Mediante el PPO, los servicios del ámbito de los medios audiovisuales se sujetan únicamente a las disposiciones vigentes en el país en el que están sometidos.

Se trata de un conjunto de criterios que determinan la competencia judicial sobre los proveedores y los procedimientos de excepción y cooperación que limitan la libertad de recepción y retransmisión en casos específicos.

Es importante señalar que la aplicación del PPO no afecta a la territorialidad de los derechos de autor o al alcance de las licencias en un sector.

En este sentido, cabe recordar, de un lado, que los derechos de autor son, por naturaleza, de carácter territorial. Es decir, se regulan por una concreta legislación nacional. Y, de otro, que las licencias se suelen conceder de ordinario para un ámbito concreto sin que abarque la totalidad de los posibles usos comerciales amparados por los derechos de propiedad intelectual licenciados. 
La propuesta de nueva Directiva únicamente establece en qué jurisdicción tiene lugar el acto del que se derivan los derechos de autor y simplifica el régimen regulador de la radiodifusión, por lo que no es necesaria ninguna disposición sobre la territorialidad o la concesión de licencias.

En resumen, la propuesta reafirma el principio de libertad de retransmisión y, al mismo tiempo, simplifica las normas que determinan qué país tiene jurisdicción sobre un proveedor.

\subsection{Comunicaciones comerciales audiovisuales}

La propuesta de Directiva presentada por la Comisión pasa por desregularizar las comunicaciones comerciales. Éstas son “imágenes o sonidos destinados a promocionar, de manera directa o indirecta, los bienes, servicios o imagen de una persona física o jurídica dedicada a una actividad económica. Estas imágenes o sonidos acompañan a un programa o se incluyen en él a cambio de una contraprestación a favor del prestador del servicio"12.

No obstante, el legislador europeo ha introducido un importante contrapeso, por cuanto si bien mantiene el límite de contenido publicitario en el 20 por ciento en la franja horaria de 7 a 23 horas, flexibiliza las normas de emplazamiento de producto y hace hincapié en las normas de autorregulación en aras de la protección de los sectores más vulnerables.

Precisamente, la protección de los más vulnerables (sobre todo, menores) constituye uno de los ejes centrales del texto presentado por la Comisión. En concreto, busca alejarlos de la exposición a comunicaciones comerciales que promuevan alimentos con alto contenido en grasas y azúcares, tabaco o bebidas alcohólicas.

\subsection{Protección del menor}

La actitud activa por parte de los proveedores de servicios es, sin lugar a dudas, uno de los objetivos más relevantes que persigue la nueva

${ }^{12}$ Apdo. 24 del art. 2 de la Ley 24/2010, de 31 de marzo, General de la Comunicación Audiovisual. 
Directiva. Ello viene motivado, en gran medida, por el auge notable del consumo de contenidos a través de Internet por parte de los menores.

En este sentido, el deseo del legislador europeo se traduce en fomentar una actitud de responsabilidad activa por parte de los proveedores de contenidos y servicios audiovisuales en línea y, también, por parte de los radiodifusores tradicionales. De hecho, se establecen normas comunes para todos los proveedores de servicios de comunicación audiovisual sin distinción.

En efecto, del tenor literal de la nueva propuesta se infiere una responsabilidad activa por parte de los proveedores de contenidos en línea. Hasta ahora, esta responsabilidad había sido pasiva, pero la futura Directiva consagra una responsabilidad activa, al señalar:

Una parte importante de los contenidos almacenados en una plataforma de distribución de vídeos no están bajo la responsabilidad editorial del proveedor de dicha plataforma. No obstante, esos proveedores suelen determinar la organización de los contenidos, a saber, programas o vídeos generados por los usuarios, incluso por medios o algoritmos automáticos. Por lo tanto, los proveedores deben estar obligados a adoptar las medidas adecuadas para proteger a los menores de los contenidos que puedan perjudicar $[\ldots]^{13}$.

Se adelanta la responsabilidad, que bascula desde una postura pasiva a una posición activa, ex ante, por lo que los proveedores de contenidos en línea deben adoptar a su vez una posición in vigilando, al ser ahora sujetos garantes de buena parte de las obligaciones inherentes a los contenidos que alojen en sus plataformas, ya sea directamente o a través de enlaces a otras páginas web -prácticas de linking, deep linking o framing, por ejemplo- que, a su vez, pueden impactar en derechos de propiedad intelectual. Volveremos sobre esta importante cuestión más adelante.

Orillada la cuestión de la incidencia de ciertas prácticas en los derechos de autor, interesa ahora subrayar que el cambio del legislador europeo responde, a su vez, a la transformación en los hábitos de consumo de contenidos audiovisuales por parte de los usuarios, muchos de ellos transformados en emisores (de hecho, gran parte de la programación

${ }^{13}$ Vid. Considerando 28. 
de plataformas de contenidos en línea está integrada por material generado por los propios usuarios).

El elenco de medidas que podrán imponer los EE.MM. a los proveedores de contenidos audiovisuales va desde la simple definición de "contenidos peligrosos" hasta la obligación de adopción de sistemas de control parental, verificación de la edad o identificación de contenidos en función de ciertos códigos de edad, pasando por la instauración de mecanismos que permitan a los usuarios de las plataformas (los que producen contenidos que suben a la plataforma o los que acceden a los vídeos colgados) calificar, notificar e indicar al proveedor del servicio que se trata de contenidos del tipo comentado.

De esta forma, por ejemplo, plataformas como YouTube podrán verse obligadas a adoptar mecanismos de identificación de los contenidos (por ejemplo, peligrosos) alojados en su web.

\subsection{Prohibición del discurso del odio}

Junto a la flexibilidad, la armonización de medidas oportunas para proteger a los menores de los contenidos nocivos y a todos los ciudadanos de los contenidos que inciten a la violencia o al odio, constituye la piedra angular de la propuesta de Directiva.

Con carácter general, este Instrumento normativo prohibirá todas las formas y manifestaciones de racismo y xenofobia, la incitación a la violencia y al odio por razón de sexo, raza, color, religión, ascendencia u origen nacional o étnico.

En particular, tal y como estipula el Considerando 31 del texto propuesto:

[...] debe buscarse un cuidadoso equilibrio con los derechos fundamentales aplicables, consagrados en la Carta de los Derechos Fundamentales de la Unión Europea. Están afectados en particular, según el caso, el derecho al respeto de la vida privada y familiar y la protección de los datos de carácter personal, la libertad de expresión y de información, la libertad de empresa, la prohibición de discriminación y los derechos del niño.

La conjugación de este equilibrio, que cristaliza en el deseo del legislador europeo de armonizar la normativa de los EE.MM. de la UE, 
no resulta sencilla. El estándar que introducirá la nueva Directiva supone un desafío, por cuanto es más elevado que algunos derechos fundamentales consagrados en las respectivas constituciones de los países miembros de la Unión.

\subsection{Promoción de obras europeas: reserva del 20 por ciento del catálogo de programación}

Toda la legislación del sector audiovisual europeo está atravesada por la salvaguarda de un presupuesto -la exception culturelle française-, mediante el que se han excluido los contenidos audiovisuales de los tratados de libre comercio, en aras de fomentar la industria audiovisual de la Unión a través de imposición de cuotas de exhibición, subvenciones a productores, realizadores, etcétera, medidas fiscales que potencien las producciones locales u obligar a incluir en los catálogos de programación de los proveedores de contenidos audiovisuales un porcentaje mínimo de contenidos europeos.

En efecto, la propuesta recoge la obligación de reservar el 20 por ciento de la programación a obras europeas, imposición que es extensiva a todos los proveedores de contenidos audiovisuales.

La extensión de esta disposición a todos los operadores ha sido aplaudida por la doctrina, que ha bendecido la medida,

considerando que, actualmente, las empresas de radiodifusión televisiva europeas invierten alrededor del $20 \%$ de su volumen de negocios en contenidos originales y los proveedores a la carta, menos del $1 \%$, la Comisión pretende que dichas empresas sigan destinando al menos la mitad del tiempo de emisión a obras europeas y obligará a los proveedores a la carta a velar por que en sus catálogos haya al menos una participación del $20 \%$ de contenidos europeos (Mendoza Losana, 2016; pág. 3).

Ha sido siempre ésta una medida muy discutida por parte de los radiodifusores (sobre todo, de carácter privado) que han tratado con denuedo de expulsar o, cuanto menos, de suavizar la medida con propuestas que excluyesen la obligación sobre los resultados brutos de explotación, en la convicción de que la medida mermaba no sólo sus ingresos sino también su competitividad.

En cualquier caso y, conforme a la propuesta, corresponde a los EE.MM. decidir si, además, imponen obligaciones de financiación de 
obras europeas a los servicios a la carta disponibles en su país, pero establecidos en otro Estado miembro (art. 13.2 de la propuesta de Directiva) ${ }^{14}$.

En línea con la flexibilidad normativa que permite una directiva, la propuesta deja a los EE.MM. la forma en que deben concretarse las aportaciones financieras. Estas contribuciones pueden consistir tanto en inversiones directas como en exacciones a fondos cinematográficos nacionales.

En este caso, las contribuciones financieras se basarán exclusivamente en los ingresos obtenidos en los EE.MM. Si el Estado miembro en que está establecido el prestador impone una contribución financiera, deberá tener en cuenta las eventuales contribuciones financieras impuestas por los EE.MM. de recepción. Cualquier contribución financiera deberá ajustarse al derecho de la Unión, en particular a la normativa sobre ayudas estatales ${ }^{15}$.

Al objeto de asegurar que las obligaciones en materia de promoción de las obras europeas no socaven el desarrollo del mercado y permitir la entrada de nuevos operadores, la nueva Directiva exime del cumplimiento de estas imposiciones a las empresas con escasa presencia en el mercado (por ejemplo, aquéllas con un bajo volumen de facturación o audiencias exiguas):

Los Estados miembros dispensarán de los requisitos establecidos en los apartados 1 y 2 a los proveedores con un bajo volumen de negocios o una baja audiencia, o que sean pequeñas empresas y microempresas. Los Estados miembros podrán también obviar los requisitos en los casos en que resulten impracticables o injustificados en razón de la naturaleza del tema del servicio de comunicación audiovisual a petición ${ }^{16}$.

\footnotetext{
${ }^{14}$ Ibidem.

15 Art. Cit.

${ }^{16}$ Comisión Europea. 2016. Propuesta de Directiva del Parlamento Europeo y del Consejo por la que se modifica la Directiva 2010/13/UE, sobre la coordinación de determinadas disposiciones legales, reglamentarias y administrativas de los Estados miembros relativas a la prestación de servicios de comunicación audiovisual, a la vista de la evolución de las realidades del mercado. Art. 13.5.
} 
Sin embargo, el aspecto más controvertido tal vez sea el contenido en el apdo. segundo del artículo 13:

Los Estados miembros podrán exigir a los prestadores de servicios de comunicación audiovisual bajo su competencia judicial una contribución financiera a la producción de obras europeas, por ejemplo, mediante inversiones directas en contenidos y aportaciones a fondos nacionales. Los Estados miembros podrán exigir la realización de estas contribuciones financieras a los prestadores de servicios de comunicación audiovisual a petición dirigidos a públicos de sus territorios, pero establecidos en otros Estados miembros. En este caso, las contribuciones financieras se basarán exclusivamente en los ingresos obtenidos en los Estados miembros de recepción. Si el Estado miembro en que está establecido el prestador impone una contribución financiera, deberá tener en cuenta las eventuales contribuciones financieras impuestas por los Estados miembros de recepción. $[\ldots]^{17}$.

En efecto, de la redacción del precepto se colige que la nueva Directiva faculta a los EE.MM. a levantar barreras de mercado ("podrán exigir [...] una contribución financiera a la producción de obras europeas [...]"), de un lado. Y, de otro, que los radiodifusores y prestadores de servicios de comunicación audiovisual establecidos fuera del territorio UE pueden soslayar la referida obligación.

Por lo tanto, una interpretación ad literam del precepto nos lleva a concluir que: i) la propuesta contiene una importante contradicción, en la medida que se permite a los EE.MM. establecer restricciones a las emisiones transfronterizas, lo que choca frontalmente con la normativa europea vigente, que promueve la libre circulación de bienes y servicios, y ii) es disuasoria de futuras inversiones, por cuanto indirectamente incentiva que los prestadores de servicios transfronterizos se radiquen fuera de la UE, al quedar ayunos los EE.MM. de mecanismos jurídicos para exigir la contribución financiera a la producción de obras europeas.

\subsection{Plataformas de distribución de vídeos}

La propuesta de Directiva extiende los efectos de la normativa audiovisual a las plataformas de distribución de vídeos (hasta ahora las

${ }^{17}$ Vid. Art. 13.2 DCSA (II). 
obligaciones contenidas en la normativa audiovisual europea recaían únicamente sobre el espinazo de los broadcaster tradicionales).

En efecto, el difícil equilibrio que bascula entre el fomento de la competitividad y la protección del consumidor se conjuga en la equiparación de las mismas reglas a las nuevas plataformas online.

Este deseo del legislador europeo ha cristalizado en la inclusión de un nuevo capítulo en la propuesta de Directiva, dedicado íntegramente a las plataformas de distribución de vídeos.

La inclusión de este Capítulo, cuya rúbrica es Disposiciones aplicables a los servicios de plataformas de distribución de vídeos, que se compone únicamente de dos únicos preceptos (artículos 28 bis y 28 ter) responde a una cuestión doble: i) reflejar la realidad en el plano legal, por cuanto el consumo de contenidos a través de operadores de Internet no para de crecer (sobre todo, vía streaming), y ii) establecer un marco común de derechos y obligaciones para todos los actores.

En este sentido, la nueva Directiva supone un marco regulador que refleja la realidad de un mercado que hasta ahora había sido sectorializado. No tenía sentido imponer unas reglas de juego determinadas a unos operadores (en función, por ejemplo, de la tecnología por la que se transmitían los contenidos audiovisuales) en detrimento de otros.

La propuesta termina en parte con esta distorsión, que comportaba distintos niveles de protección para el usuario y se aproxima a la nueva realidad, que a su vez pivota sobre nuevas formas de consumo (vídeos bajo demanda, dispositivos de pocas pulgadas -como tablets y smartphones-, contenidos producidos por los propios usuarios, etcétera).

La imposición expresa a las plataformas de distribución de obligaciones que impidan la difusión de contenidos nocivos para menores, en general, y que combatan el discurso del odio, en particular, son las dos medidas clave, junto a la salvaguarda del interés general, que persigue la propuesta analizada.

El auge del consumo de contenidos audiovisuales vía streaming ha sido, muy posiblemente, el factor catalizador del cambio. 
La aprobación de la propuesta de Directiva permitirá no sólo que la UE pueda exigir a las nuevas plataformas online, por ejemplo, inversión en obras europeas (según se desprende del texto, el 20 por ciento, tal y como se ha apuntado anteriormente) sino, también, responder de obligaciones que hasta ahora eran sólo inherentes a los radiodifusores tradicionales.

Responsabilidad editorial y obligaciones en materia de derechos de autor son, quizás, los dos aspectos más sobresalientes a los que deberán hacer frente los nuevos operadores tras la entrada de la nueva Directiva.

La visualización de un video en Internet con incidencia en la propiedad intelectual puede agruparse en cuatro grandes categorías: i) las descargas (downloading); ii) las redes peer-to-peer; iii) los enlaces (linking y deep linking), y iv) el streaming. En esta Comunicación, nos centraremos en esta última por ser la forma masiva de consumo de videos y, éstos, a su vez, el formato por excelencia llamado a protagonizar el cambio de paradigma de consumo de contenidos.

Señalábamos anteriormente que el objetivo general de la propuesta de Directiva es lograr un equilibrio entre la competencia leal y establecer medidas tuitivas para el consumidor. Y ello sin olvidar, además, la promoción y la estimulación de la innovación y la creatividad.

Una conjugación de intereses difícil, si se tiene en cuenta que los derechos de propiedad intelectual crean barreras legales al acceso o uso del conocimiento por parte de terceros mediante la atribución de derechos exclusivos a los inventores y creadores.

Estos derechos exclusivos evitan que terceros se aprovechen del esfuerzo ajeno y a su vez, permiten al titular de los derechos explotar su conocimiento o creatividad en el mercado y obtener rendimientos económicos, incentivando con ello la creatividad y la innovación.

El progreso y el desarrollo de la SC se fundamentan en que dicho conocimiento sea compartido ampliamente, ya que permite que las creaciones de otros sirvan de inspiración y referencia para la creatividad ajena. 
En efecto, gran parte del valor de la creatividad o de la actividad innovadora que protege la propiedad intelectual viene del hecho de que la misma sea accesible a otros. Así, para proteger una idea, ésta debe hacerse pública, de forma que se una al acervo común que posibilita el progreso de la sociedad.

El streaming es la distribución digital de contenido multimedia protegido por derecho de autor que espolea ese conocimiento a través de una red de ordenadores en tiempo real. Mediante la modalidad de streaming, los datos se reproducen en el mismo acto a través de un sistema se conoce como búfer, por lo que el contenido no se almacena en el disco duro.

Al tratarse de una retransmisión fluida, continua y sin interrupciones, se orilla el almacenamiento, que es una conducta sobre la que sí impacta la propiedad intelectual. Los datos se alojan en una página caché (que es temporal). De hecho, sólo pueden visualizarse si el usuario continúa en la misma página web porque, si cambia, la caché borra los datos almacenados.

La cuestión del alojamiento temporal constituye, de hecho, el argumento principal que ha permitido soslayar la litigiosidad que ha suscitado esta conducta en torno a la posible vulneración de derechos de autor.

No obstante, si la cuestión de la temporalidad había sido esgrimida hasta ahora con cierto éxito para soslayar la cuestión de los derechos de autor, ello no ha sido óbice para que los mismos se protejan por otra vía. Es el caso del derecho de reproducción o de comunicación pública.

Mediante el primero, los autores hacen efectivo su derecho a que la obra se fije en un medio que permita su comunicación y la obtención de copias de toda o parte de ella. A través del segundo, ejercen su derecho a que una pluralidad de personas pueda tener acceso a la obra sin previa distribución de cada una de ellas.

Entre las prácticas más habituales para posibilitar el acceso a contenidos es el linking. El programa que sustenta la operación de Internet permite que la información sea híper vinculada (byperlinked o bypertext reference linked) dentro y entre sitios. Dicha vinculación (linking) ocurre cuando el creador de una página web provee una referencia a 
otra, usualmente indicado en textos de color o iconos, utilizando un software que le permite al usuario hacer clic en la referencia y ver el contenido en la página vinculada (un link). Mientras esto permite a los usuarios navegar de manera fluida ente páginas web, esto también genera problemas relacionados con los derechos de autor.

Un simple link (una vinculación) de una página web al inicio de otra normalmente no genera ninguna preocupación, ya que el uso de dichos links puede equipararse al uso de pies de página para referirse a otras páginas. Frecuentemente no se requiere un permiso para hacer un link de un sitio web, debido a que el titular ha otorgado una licencia implícita a vincular su material al hacerlo disponible en línea, o por caracterizar esa vinculación como uso justo.

Sin embargo, esta práctica ha generado un torrente jurisprudencial por parte del TJUE, que ha ido pronunciándose sobre la responsabilidad en los casos de incumplimiento de derechos de autor, que no han sido precisamente pocos.

De este modo, a través de distintos asuntos, el TJUE ha desarrollado el concepto de "comunicación pública" como un derecho exclusivo de autores y otros titulares de derechos conexos de propiedad intelectual.

Mediante los conocidos asuntos Svensson, BestW ater y GS Medida, el Alto Tribunal europeo comienza a concretar y modular la naturaleza jurídica de la práctica del linking en Internet al introducir distintos conceptos dentro del derecho de comunicación pública.

No ha habido una jurisprudencia consolidada sobre la cuestión hasta $2017^{18}$, que constituye un punto de inflexión en esta materia. El 26 de abril de 2017, el TJUE se pronuncia sobre los derechos de reproducción y de comunicación pública en la ya conocida Sentencia (C-527/15 Filmspeler), en la que responderá a una cuestión prejudicial planteada por un tribunal de instancia holandés.

Una empresa comercializada en Internet distintos modelos de un reproductor multimedia denominado Filmspeler, que permitía el acceso a obras protegidas disponibles en sitios de difusión en flujo continuo (streaming) y visualizarlas en una pantalla de tv. El TJUE concluyó que ${ }^{18}$ De hecho, el Alto Tribunal ha adoptado en los últimos años Resoluciones controvertidas -como la del Asunto
SFC. Del Corso (C-135/10)-, que modulan el derecho exclusivo de comunicación pública. 
la venta del reproductor constituye una comunicación al público en el sentido recogido en la Directiva de 2001 sobre Derechos de Autor, tras recordar que el citado Instrumento normativo tiene como objetivo la instauración de un nivel elevado de protección en favor de los autores.

La cuestión de hacer efectivo el derecho de comunicación pública a sus legítimos titulares es la razón última por la que existen las normas de propiedad intelectual, que persiguen fomentar y proteger la innovación y la creatividad. Pero éstas se deben conjugar con aquéllas que persiguen la competencia efectiva en el marco de un mercado íntegro que a su vez contenga medidas tuitivas para los consumidores. Una tarea que se antoja difícil para el legislador que se ha propuesto crear el Mercado Único Digital, de ahí que la tarea interpretadora del TJUE resulte esencial en una cuestión tan viva.

\subsection{Accesibilidad}

En diciembre de 2015, en el marco del paquete de medidas propuestas por la Comisión para fomentar el Mercado Único Digital, el legislador europeo adoptó una propuesta de Acta Única de Accesibilidad ${ }^{19}$, que fija los requisitos de accesibilidad de una amplia gama de productos y servicios, incluidos los servicios de comunicación audiovisual. Por lo tanto, se eliminan las disposiciones sobre accesibilidad.

En concreto, se suprime el artículo 7 de la Directiva actual, habida cuenta de que la propuesta de Acta Europea de Accesibilidad establece ya unos requisitos comunes más estrictos en materia de accesibilidad para los prestadores de servicios de comunicación.

\subsection{Reguladores audiovisuales}

Bajo la rúbrica Autoridades reguladoras de los Estados Miembros, el precepto que encabeza este Capítulo -el artículo 30- está dedicado a las autoridades reguladoras nacionales independientes.

Si bien el catálogo de cuestiones que propone la Directiva no es exhaustivo, cinco son las competencias que otorga a los reguladores audiovisuales: la defensa del pluralismo informativo de los medios de

${ }^{19}$ Vid. COM (2015) 615 (http:/ / eur-lex.europa.eu/legal content/EN/TXT/?uri=COM\%3A2015\%3A615\%3AFIN). 
comunicación, la diversidad cultural, la protección de los consumidores, el mercado interior y la promoción de la competencia leal.

Se da la circunstancia que España es de los pocos países del entorno europeo que carece de una autoridad reguladora independiente del sector audiovisual, lo que parte de la doctrina consolidada no duda en calificar como "la condición excepcional de la situación española" (por todos, Botella Corral, 2007, pág. 7).

Sin embargo, cuando parece haberse instalado la convicción del necesario establecimiento de unos consejos audiovisuales independientes, efectivos y con competencias reales, el legislador europeo se ha adelantado.

En efecto, tras la aprobación del texto final, España tendrá cuatro años por delante para implementar la nueva Directiva en nuestro ordenamiento jurídico. Al respecto, dos son las opciones que, en la práctica, se tiene que plantear: i) crear una autoridad ex novo, o ii) ampliar las competencias actuales de la CMT, integrada en la CNMC, que actualmente está ayuna de atribuciones en materia de contenidos.

\subsection{Formalización del Grupo de Entidades Reguladoras Europeas para los Servicios de Comunicación Audiovisual}

La voluntad decidida del legislador europeo de armonizar las competencias de los reguladores audiovisuales nacionales independientes cristaliza en la formalización del Grupo de Entidades Reguladoras Europeas para los Servicios de Comunicación Audiovisual (ERGA).

Prueba de ello es la inclusión en este Capítulo del artículo 30 bis, que está concebido para reforzar la conformación y preservación del mercado interior.

Integrado por las autoridades reguladoras independientes nacionales en el ámbito de los servicios de comunicación audiovisual, la propuesta de Directiva plantea conferir al ERGA las competencias siguientes ${ }^{20}$ :

${ }^{20}$ Vid. Art. 30 bis DCSA (II). 
i) asesorar y asistir a la Comisión en su labor de garantizar la aplicación coherente del marco regulador de los servicios de comunicación audiovisual en todos los EE.MM.;

ii) asesorar y asistir a la Comisión en cualquier aspecto relacionado con los servicios de comunicación audiovisual dentro de las competencias de la Comisión; si estuviese justificado con el fin de asesorar a la Comisión sobre determinadas cuestiones, el Grupo podrá consultar a los participantes en el mercado, consumidores y usuarios finales, con el fin de recopilar la información necesaria;

iii) facilitar el intercambio de experiencias y buenas prácticas en lo relativo a la aplicación del marco regulador de los servicios de comunicación audiovisual;

iv) cooperar y facilitar a sus miembros la información necesaria para la aplicación de la presente Directiva (en particular, en lo que atañe al principio de libertad de retransmisión, la oposición de excepción y en la extensión de la normativa inherente al sector audiovisual a los prestadores de servicios de comunicación audiovisual), $\mathrm{y}$

v) emitir dictámenes, a petición de la Comisión, sobre asuntos relativos a los servicios de comunicación audiovisual, en particular la protección de los menores y la incitación al odio.

El elenco de atribuciones que la propuesta confiere al ERGA se refuerza con la potestad que la nueva Directiva otorga al macroorganismo regulador de emitir dictámenes.

En concreto, el ERGA podrá emitir dictámenes relativos a las cuestiones contempladas en el artículo 2, apartado 5 ter, artículo 6 bis, apartado 3, y artículo 9, apartados 2 y 4 . Esto es, para dirimir sobre cuestiones relativas a competencia judicial si eventualmente los EE.MM. interesados no han logrado alcanzar algún acuerdo ${ }^{21}$, para pronunciarse sobre posibles incumplimientos en materia de información sobre contenido por parte de los prestadores de servicios de comunicación audiovisual (en especial, aquéllos que puedan

${ }^{21}$ Vid. Art. 2 apdo. 5 ter bis DCSA (II). 
perjudicar el desarrollo físico, mental o moral de los menores ${ }^{22}$, así como para resolver sobre cuestiones relacionadas con la elaboración de códigos de conducta de autorregulación y corregulación en relación con las comunicaciones comerciales audiovisuales inadecuadas ${ }^{23}$.

¿Por qué estas atribuciones están reforzadas? Porque la nueva Directiva le ha conferido a este Organismo potestad sancionadora. En principio, un dictamen es un Instrumento jurídico que no tiene fuerza vinculante.

Ahora bien, del tenor literal del precepto se desprende que la emisión de dictámenes se hará previa solicitud de la Comisión. Elevado a la Comisión, ésta sí dispone de capacidad sancionadora. De hecho, la emisión de dictámenes motivados forma parte del iter formal de los procedimientos sancionadores.

No obstante, este aspecto es un "verso suelto" en el espíritu de una Directiva que rezuma desregulación.

\subsection{El concepto de servicio audiovisual público en el marco del nuevo ecosistema digital y en la futura Directiva}

Herencia de la llamada exception culturelle française, el concepto de "servicio público" permanece petrificado en su significado, extensión y alcance en el Estatuto de Radio Televisión Española de 1981.

¿Qué implica, por lo tanto, el concepto de "servicio público"? Nada menos, que todas las televisiones en España, sea cuál sea su titularidad y su cobertura geográfica, tienen todavía hoy la consideración legal de "servicio público".

De hecho, toda la producción legislativa posterior, incluidas diversas leyes de acompañamiento de los presupuestos generales del Estado, ha mantenido esta ficción, aunque era manifiesto que la era del monopolio estatal de la televisión había quedado atrás ${ }^{24}$.

${ }^{22}$ Vid. Art. 6 bis apdo. 3 DCSA (II).

${ }^{23}$ Vid. Art. 9 apdos. 1 y 2 DCSA (II).

${ }^{24}$ Art. Cit. 
Esta concepción se mantiene en el espíritu de la nueva Directiva. Por ejemplo:

[...] y proteger a todos los ciudadanos frente a la incitación a la violencia o al odio dirigidos contra un grupo de personas o un miembro de tal grupo, definido en relación con el sexo, la raza, el color, la religión, la ascendencia o el origen nacional o étnico ${ }^{25}$.

Esta naturaleza tuitiva imprima consistencia al concepto de "servicio público". Más aún. A pesar del deseo del legislador europeo de desregular muchas cuestiones inherentes al sector audiovisual, en parte debido a su dinámica intrínseca convergente, el concepto de "servicio público" permanece incólume en la presente propuesta, y ello a pesar de que no hay una sola referencia en todo el texto.

El 3 de abril de 2010 se produjo el apagón analógico de la televisión por ondas hertzianas, momento a partir del que las emisiones de televisiones terrestres comenzaron a realizarse mediante técnicas digitales.

La digitalización de las redes por ondas terrestres, fenómeno que inyectó un mayor ancho de banda en el espectro radioeléctrico -un bien demanial escaso sobre el que los sucesivos gobiernos habían ejercido un férreo control-, comportó un aumento de canales.

No obstante, el incremento de canales que propició el encendido digital como consecuencia del aumento de la capacidad de banda ancha no vino acompañado de un crecimiento del consumo de televisión convencional.

Al contrario, a pesar de la extraordinaria fortaleza que había mostrado el consumo hasta la llegada de la TDT, ésta supone un punto de inflexión, tanto en términos cuantitativos como cualitativos.

En efecto, la introducción de la tecnología TDT no sólo trae consigo una disminución del consumo de minutos (tendencia que sólo se "rompe" en 2017, en parte porque se han introducido en las mediciones "invitados" -espectadores que no viven en el hogar y se encuentran en éste viendo la televisión-) sino, también, en términos cualitativos, por cuanto el target joven ha protagonizado una huida hacia

${ }^{25}$ Vid. Considerando 28 DCSA (II). 
otros universos digitales, lo que ha propiciado una disminución de consumo de televisión lineal.

Concebida como una tecnología de sustitución, la TDT se planteó sobre un modelo de comunicación que pronto fue superado por otras tecnologías gestionadas por actores de diversos sectores (telecomunicaciones, distribución, etc.).

Dos son los tipos de consumo de televisión. Por un lado, está el consumo off-line, que es aquél que coincide con una forma tradicional (o lineal) de ver contenidos televisivos, que se sustenta en una programación con horarios establecidos. De otro, el consumo on-line, que permite visualizar contenidos de manera no lineal, a posteriori, vía Internet.

El cambio de paradigma de consumo televisivo comienza con el nacimiento de la plataforma por streaming YouTube en 2005, que supone una revolución en la distribución de contenidos multimedia.

Esta distribución digital de contenidos multimedia a través de smart tvs, smartphones, tablets, etc., que, sin duda, ha alterado sustancialmente los hábitos de consumo de la programación televisiva que conocemos tradicionalmente, se verá espoleada con la tecnología $5 G$.

En este sentido, tres serán los vectores de acción que cincelarán una redefinición del modelo audiovisual en el quinquenio 2020-2025: la economía $5 G$, los gigantes digitales y los nuevos operadores de la industria de la televisión.

Por lo tanto, el motor de este cambio será la distribución digital, auspiciada por el corolario de gadgets multimedia que, propulsados por la velocidad (en clave de $5 G$ ), redefinirán el consumo de contenidos.

A los operadores tradicionales se suman ya nuevos players (YouTube, Netflix y HBO, entre los más conocidos). Y, del lado de la distribución, habrá que tener muy en cuenta a Google TV, Facebook TV y Amazon Prime Video.

El video es, precisamente, el formato de consumo televisivo por excelencia que está llamado a protagonizar el gran cambio en la forma de consumo. 
De hecho, este cambio de paradigma -el consumo de vídeo vía streaming- es la cuestión nuclear de la nueva Directiva -y su principal desafío-, dado que deberá dotar de seguridad jurídica a todos los actores, actualmente sujetos a normativas diferentes y con desigual protección.

\section{Conclusiones}

El consumo de contenidos a la carta -en particular, de vídeos- vía tecnología streaming ha espoleado la aparición de nuevos actores en el sector audiovisual. A la par que consumidores, los nuevos players son también competidores de los operadores tradicionales.

En el nuevo ecosistema digital, conformado por radiodifusores tradicionales, prestadores de servicios por Internet y contenidos generados usuarios, la asimetría es la nota que caracteriza la situación de partida, por cuanto están sujetos a normativas diferentes y a niveles de protección desiguales.

Con un espíritu teñido de desregulación, el legislador europeo ha propuesto la DSCA (II), que tiene como objetivo principal armonizar la actual normativa del sector audiovisual y adaptarla a la nueva realidad, a fin de reflejar todos estos cambios en el mercado, el consumo y la tecnología, pero manteniendo una actitud hipergarantista en cuestiones como el "servicio público", un bien jurídico que sigue presidiendo la regulación del sector audiovisual.

\section{Referencias bibliográficas}

\section{Artículos}

Botella Corral, J. 2007. La regulación independiente del sector audiovisual español: una reflexión sobre problemas, perspectivas y posibilidades. Revista catalana de dret públic. Núm. 34. Pp. 1-8

López Olano, C. 2016. Las autoridades de regulación en España.

Panorámica y perspectivas del control de la pluralidad. Miguel Hernández Communication Journal. Pp. 1-26

Mendoza Losana, A. I. 2016. Régimen de las plataformas de distribución de vídeos en la nueva directiva de comunicación 
audiovisual. Propuesta de revisión de la directiva 2010/13/UE de comunicación audiovisual (II). Gómez. Acebo \& Pombo. Pp. 1-4

Reda, J. 2016. Proyecto de opinión de la Comisión de Mercado Interior para la Comisión de Asuntos Jurídicos sobre la propuesta de Reglamento del Parlamento Europeo y del Consejo por el que se establecen las normas sobre el ejercicio de los derechos de autor y determinados derechos afines a los derechos de autor aplicables a determinadas transmisiones en línea de los organismos de radiodifusión y a las retransmisiones de programas de radio y televisión (COM(2016)0594-C8-0384/2016-2016/0284(COD)). Parlamento Europeo. Comisión de Mercado Interior y Protección del Consumidor. Pp. 1-25

\section{Legislación}

Comisión Europea. 2016. Propuesta de Directiva del Parlamento Europeo y del Consejo por la que se modifica la Directiva 2010/13/UE, sobre la coordinación de determinadas disposiciones legales, reglamentarias y administrativas de los Estados miembros relativas a la prestación de servicios de comunicación audiovisual, a la vista de la evolución de las realidades del mercado. Comisión Europea. Pp. 1-36.

\section{Otros documentos}

Albarrán, C (2018). Internet domina el consumo de contenidos audiovisuales en España. Artículo online. Redes Telecom. Recuperado el 9 de junio de 2018, de http://www.redestelecom.es/internet/noticias/11056570019 $\underline{03 / \text { internet-domina-consumo-de-contenidos-audiovisuales- }}$ espana.1.html

Panorama audiovisual (2017). Nueva Directiva europea del audiovisual ¿esperanza o amenaza? Artículo online. Panorama audiovisual. Recuperado el 10 de junio de 2018, de https://www.panoramaaudiovisual.com/2017/05/25/nuevadirectiva-europea-del-audiovisual-esperanza-o-amenaza/ 



\title{
Transparencia y gestión en las televisiones públicas del Suroeste europeo
}

\author{
Carmen del Rocío Monedero Morales \\ Silvia Olmedo Salar \\ Universidad de Málaga
}

PARA CITAR: Monedero Morales, C. R. y Olmedo Salar, S. (2018). Transparencia y gestión en las televisiones públicas del Suroeste europeo. En Rodríguez-Castro, M., Pérez-Seijo, S. y Campos-Freire, F. (Eds.). La TV Pública en Europa: Innovación, Retos y Tendencias (73-88). Cuadernos Artesanos de Comunicación, cac 146. La Laguna (Tenerife): Latina. DOI: 10.4185/cac146.

\section{Resumen}

La transparencia en la gestión de los recursos públicos ha dejado de ser una opción para convertirse en una obligación en la mayoría de países de la Europa Comunitaria. Los medios de comunicación públicos no son una excepción a esta nueva dimensión social y es a través de sus sitios web donde la mayoría de los usuarios pueden acceder a la información referida a la gestión, el capital social, los órganos de control y una larga lista de cuestiones estructurales. El presente texto pretende proponer y aplicar un indicador que mida el grado de transparencia y rentabilidad social que reflejan las webs de los principales canales nacionales generalistas públicos del Suroeste europeo: TVE 1 (España), RTP1 (Portugal); FR1 (Francia) y RAI 1 (Italia). Para ello se partirá del Índice de Rentabilidad Social en Comunicación (IRSCOM), compuesto por 32 valores agrupados en seis áreas: transparencia, capital social, infraestructuras, programación, uso de NNTT y articulación territorial. El objetivo principal de la 
propuesta es desarrollar una herramienta homologable a nivel internacional que mida e incida en la rentabilidad social con la que las televisiones públicas generalistas realizan su labor de información y comunicación dirigida a la ciudadanía, destacando su gestión, pluralidad y diversidad de la programación, adecuación de contenidos de utilidad pública y uso de las nuevas tecnologías.

Palabras clave: indicadores, servicio público, transparencia, entes públicos, rentabilidad social

\section{Introducción}

La transparencia en la gestión de los recursos públicos ha dejado de ser una opción para convertirse en una obligación en la mayoría de países de la Europa Comunitaria. Los medios de comunicación públicos no son una excepción a esta nueva dimensión social y es a través de sus sitios web donde la mayoría de los usuarios pueden acceder a la información referida a la gestión, el capital social, los órganos de control y una larga lista de cuestiones estructurales.

El presente texto pretende proponer y aplicar un indicador que mida el grado de transparencia y rentabilidad social que reflejan las webs de los principales canales nacionales generalistas públicos del Suroeste europeo: RTVE (España), RTP (Portugal); FR (Francia) y RAI (Italia). Estos países han sido seleccionados por su cercanía geográfica y cultural.

Para ello se partirá del Índice de Rentabilidad Social en Comunicación (IRSCOM) que fue aplicado a las televisiones de proximidad de Andalucía como territorio experimental, por COMandalucía, El Laboratorio de Comunicación y Cultura de la Universidad de Málaga, del cual forman parte las dos autoras de este estudio. Los ítems que conforman dicho índice serán adaptados al ámbito de cobertura y al nivel de recursos de las televisiones ya citadas. Este índice mide tanto valores tangibles, como otros de naturaleza más intangible en la prestación del servicio público de manera fiable, rápida y contrastada.

Además, se tendrán como referencia estudios previos realizados como el de Costa y Túñez, en 2017, titulado "Información corporativa online 
de las televisiones públicas europeas y sus relaciones con la audiencia" y el de Fernández (2016), "La página web como espacio de transparencia de las radiotelevisiones públicas". En ambos se aborda una aproximación al posicionamiento web de las televisiones públicas europeas con mayor capacidad económica.

El objetivo principal de la propuesta es desarrollar una herramienta homologable a nivel internacional que mida e incida en la rentabilidad social con la que las televisiones públicas generalistas realizan su labor de información y comunicación dirigida a la ciudadanía, destacando su gestión, servicio público y uso de las nuevas tecnologías.

\section{Información corporativa a disposición pública}

La televisión de calidad es un derecho del ciudadano y una obligación para los profesionales de los medios, un criterio que afecta tanto a la programación que se emite, como a la transparencia en su gestión y el control por parte del poder político. Este deber se acentúa aún más en el caso de las emisoras de titularidad pública.

La digitalización de los procesos, la atomización de las audiencias, la multiplicación de la oferta de libre acceso mediante la TDT y la consolidación de Internet y los nuevos medios como dispositivos de consumo, conducen hacia una nueva etapa en la dinámica y el alcance de la televisión pública (Manfredi, 2011:51).

Si bien los contenidos de la programación son el elemento básico que las televisiones deben tener en cuenta, la evolución social y tecnológica hacen que, en la actualidad, la información presentada en las páginas webs de estos entes se convierta en un aspecto primordial para rendir cuentas a la ciudadanía, que en último extremo es quien los financia a través de impuestos indirectos o de un canon. Por tanto, cada vez se exige una mayor transparencia sobre la gestión del dinero público y esto supone que presupuestos, memorias, organigramas, retribuciones de altos cargos, etc. deben ser de libre acceso en la página web de los entes. En definitiva, el cuestionamiento privado y político de su sistema de financiación pública ha obligado a las respectivas corporaciones a incrementar sus niveles de transparencia sobre el destino de los fondos y sobre la necesidad de mejora de su reputación (Fernández y Campos, 2013). 
Es, por tanto, en la página web donde la emisora establece una relación bidireccional con su entorno, siendo necesario que la información que las corporaciones dirigen a sus stakeholders no se limite a la que establece la legislación mercantil (Bonsón y Escobar, 2004). El principal retorno que buscan las empresas a la hora de invertir en tecnologías web 2.0 es mejorar la interacción con sus grupos de interés (Celaya, 2008) y generar conversaciones, pasando del monólogo al diálogo, tras convertir al consumidor en el centro de todo el sistema (Madinabeitia, 2010).

Para Fidalgo (2006) la gobernanza de las empresas de comunicación no solo es una cuestión ética, sino que se trata de una estrategia para aumentar la credibilidad. Las prácticas transparentes se convierten en la herramienta de las organizaciones para poner fin al deterioro de las relaciones con su público. Fernández (2016) añade que "la falta de información es un lastre que arrastran las empresas desde hace décadas, pero acaban de identificarla como la llave de sus problemas de imagen, reputación y credibilidad".

Meier (2009) afirma que los instrumentos de transparencia y rendición de cuentas son variados y que se pueden clasificar en unidireccionales o interactivos. Se pueden ofrecer diferentes funciones: desde atender quejas hasta corregir errores o simplemente, interactuar con los televidentes.

Todos los estudios citados hasta ahora coinciden en que toda radiotelevisión, independientemente de su titularidad o ámbito de cobertura, debe tener presencia web y no solo eso, sino que tiene que permitir la contribución activa tanto de los creadores como de los usuarios, el intercambio opiniones y contenido, de manera que ambos obtengan beneficios, lo que se ha definido por Túñez y Sixto (2001) como un "compromiso 2.0".

La propia Unión Europea de Radiodifusión, organización internacional de radiodifusoras de servicio público, consciente del nuevo ecosistema mediático y de las exigencias de sus usuarios presentó en sus Estatutos (año 2015) una serie de objetivos entre los que destacamos el primero: "Promover y desarrollar el concepto de medios de servicio público, así como sus valores, destacando la 
universalidad, la independencia, la excelencia, la diversidad, la responsabilidad social y la innovación".

Una vez más, observamos que la tendencia marcada por los organismos internacionales incide en la promoción de valores corporativos de servicio público y responsabilidad social.

\section{Material y método}

Como se ha indicado con anterioridad, este estudio tiene como principal objetivo el desarrollar una herramienta homologable a nivel internacional que mida e incida en la rentabilidad social con la que las corporaciones de radiotelevisión públicas generalistas realizan su labor de información y comunicación dirigida a la ciudadanía, destacando su gestión, utilidad pública y uso de las nuevas tecnologías.

Tabla 1. Datos identificativos de los canales

\begin{tabular}{|l|l|l|l|}
\hline País & TV & Nombre & Web \\
\hline España & RTVE & $\begin{array}{l}\text { Corporación de Radio } \\
\text { y Televisión Española }\end{array}$ & http://www.rtve.es/ \\
\hline Portugal & RTP & $\begin{array}{l}\text { Rádio e Televisão de } \\
\text { Portugal }\end{array}$ & http://www.rtp.pt/ \\
\hline Francia & FR & France Televisions & https://www.francetelevisions.fr/ \\
\hline Italia & RAI & $\begin{array}{l}\text { Radiotelevisione } \\
\text { Italiana }\end{array}$ & www.raitalia.it/ \\
\hline
\end{tabular}

Fuente: elaboración propia

A raíz de éste, se formula un objetivo secundario: el revelar los índices de transparencia de las radiotelevisiones nacionales de España, Portugal, Francia e Italia a partir del análisis de la sección corporativa de sus páginas web. Se ha elegido como objeto de estudio las webs corporativas online de estos canales por suponer la principal plataforma corporativa existente al amparo del actual paradigma 2.0 (Martí, Álvarez y Domínguez, 2010).

Para el desarrollo de la investigación se ha recurrido una muestra intencional o por conveniencia (y por tanto no probabilística) formada 
por RTVE (España), RTP (Portugal); FR (Francia) y RAI (Italia) tomada durante el mes de julio de 2018.

La metodología se ha basado en técnicas cuantitativas, centrándose en el análisis de contenido de varias secciones de las páginas web de las cuatro radiotelevisiones. El estudio parte de tres parámetros, cada uno de ellos se compone de cinco indicadores:

1. Parámetro de transparencia y gestión:

1.1. ¿Es pública la financiación?

1.2. ¿Es pública la memoria de cuentas?

1.3. ¿Son públicos los miembros del Consejo de Administración?

1.4. ¿Es pública la retribución de directivos?

1.5. ¿Existen organismos de control?

2. Parámetro de servicio público:

2.1. ¿Tiene publicado su código ético?

2.2. ¿Tienen publicadas las actividades de responsabilidad social?

2.3. ¿Tiene publicados estudios e informes sobre programación y audiencias?

2.4. ¿Existen canales de comunicación bidireccionales con la audiencia?

2.5. ¿Respetan la pluralidad política y la diversidad social?

3. Parámetro de uso de nuevas tecnologías:

3.1. ¿Tiene un laboratorio de nuevos formatos?

3.2. ¿Utiliza redes sociales?

3.3. ¿Emplean herramientas de la Web 2.0. (sindicación de contenidos; blogs vinculados al medio)?

3.4. Presencia del canal en plataformas audiovisuales

3.5. Vinculación entre el sitio web del medio de comunicación y las plataformas. 
Por tanto, el estudio propone 15 indicadores aplicables a las webs de las corporaciones de televisiones públicas, para posteriormente ensayarlos de forma experimental en cuatro canales públicos nacionales del Suroeste europeo. Entendemos por indicador una variable, cuantitativa y cualitativa, medida en un periodo de tiempo determinado, que nos ofrece una base objetiva observable $y$ cuantificable para evaluar el cumplimiento de unos estándares mínimos exigibles en el cumplimiento de la función de servicio público y transparencia de una radiotelevisión estatal.

Para este cometido se diseñó una ficha de análisis que agilizase el proceso de recogida de información. La ficha fue testada sobre dos canales de la muestra para evaluar y mejorar su eficacia. Tras perfeccionar esta primera herramienta se elaboró una ficha definitiva en la que se definieron con claridad los criterios de análisis en cada variable y se unificaron los discernimientos para la puntuación de éstas.

En primer lugar, se señaló si la web ofrece o no información sobre estos indicadores. En caso positivo, se analizó el modo en el que se muestran. A cada indicador se le otorgó una puntuación (1 punto en caso de que se cumpla, 0,5 en caso de que se cumpla parcialmente y 0 puntos en el supuesto de que no se cumpla).

\section{Resultados}

Una vez analizados los tres parámetros, y sus cinco respectivos indicadores de los cuatros sitios web de las corporaciones, se revela que en general, éstas asumen como exigencias los supuestos de partida marcados por cada indicador. Las siguientes tablas sintetizan la puntuación obtenida en cada uno de ellos:

Tabla 2. Indicadores de transparencia y gestión (hasta 5 puntos)

\begin{tabular}{|l|l|l|l|l|l|l|}
\hline TV & Financiación & Memoria & $\begin{array}{l}\text { Consejo } \\
\text { Adm. }\end{array}$ & Directivos & Control & Total \\
\hline RTVE & Sí (1) & Sí (1) & Sí (1) & No (0) & Sí (1) & 4 \\
\hline RTP & Sí (1) & Sí (1) & Sí (1) & No (0) & Sí (1) & 4 \\
\hline
\end{tabular}




\begin{tabular}{|l|l|l|l|l|l|l|}
\hline FR & Sí (1) & Sí (1) & $\begin{array}{l}\text { Parcial } \\
(0,5)\end{array}$ & No (0) & Sí (1) & 3,5 \\
\hline RAI & Sí (1) & Sí (1) & $\begin{array}{l}\text { Parcial } \\
(0,5)\end{array}$ & No (0) & Sí (1) & 3,5 \\
\hline
\end{tabular}

Fuente: elaboración propia

Tabla 3. Indicadores de servicio público (hasta 5 puntos)

\begin{tabular}{|l|l|l|l|l|l|l|}
\hline TV & $\begin{array}{l}\text { Código } \\
\text { ético }\end{array}$ & $\begin{array}{l}\text { Responsabilidad } \\
\text { social }\end{array}$ & $\begin{array}{l}\text { Estudios/ } \\
\text { informes }\end{array}$ & $\begin{array}{l}\text { Comunicación } \\
\text { audiencia }\end{array}$ & $\begin{array}{l}\text { Pluralidad/ } \\
\text { diversidad }\end{array}$ & Total \\
\hline RTVE & Sí (1) & Sí (1) & Sí (1) & Sí (1) & $\begin{array}{l}\text { Parcial } \\
(0,5)\end{array}$ & 4,5 \\
\hline RTP & Sí (1) & No (0) & No (0) & Sí (1) & Sí (1) & 3 \\
\hline FR & Sí (1) & Parcial (0,5) & Sí (1) & Sí (1) & Sí (1) & 4,5 \\
\hline RAI & Sí (1) & Sí (1) & Sí (1) & Parcial $(0,5)$ & Sí (1) & 4,5 \\
\hline
\end{tabular}

Fuente: elaboración propia

Tabla 4. Indicadores uso de nuevas tecnologías (hasta 5 puntos)

\begin{tabular}{|l|l|l|l|l|l|l|}
\hline TV & Laboratorio & RR.SS. & $\begin{array}{l}\text { Herramientas } \\
2.0\end{array}$ & Plataformas & $\begin{array}{l}\text { Vinculación } \\
\text { web y redes }\end{array}$ & Total \\
\hline RTVE & Sí (1) & Sí (1) & Sí (1) & Sí (1) & Sí (1) & 5 \\
\hline RTP & Sí (1) & Sí (1) & No (0) & Sí (1) & Sí (1) & 4 \\
\hline FR & Sí (1) & Sí (1) & No (0) & Sí (1) & Sí (1) & 4 \\
\hline RAI & $\begin{array}{l}\text { Parcial } \\
(0,5)\end{array}$ & Sí (1) & Sí (1) & Sí (1) & $\begin{array}{l}\text { Parcial } \\
(0,5)\end{array}$ & 4 \\
\hline
\end{tabular}

Fuente: elaboración propia

\subsection{RTVE}

La mayoría de los indicadores del parámetro de transparencia y gestión y de servicio público aparecen recogidos en la "Memoria sobre el cumplimiento de la función de servicio público y la responsabilidad social corporativa" que se ha publicado desde 2007 hasta el año 2016, quedando pendiente la publicación de la de 2017. En ella se recoge el 
código ético (misión, visión y valores), la composición del consejo de administración, detalles sobre la financiación y la memoria de cuentas, las actividades de responsabilidad social, el organismo de control (el defensor del espectador), el respeto a la diversidad, la pluralidad, informes sobre programación y estudios sobre audiencias, entre otros aspectos. En esta memoria no se especifica la retribución de directivos, ni se mencionan los canales de comunicación bidireccionales con el público.

Fuera de este informe, en la sección "Esquema web corporativa" encontramos enlaces al Consejo de Administración en el que se puede acceder a un breve currículo vitae de sus miembros clicando sobre su fotografía. El mismo esquema se repite si se enlaza con el Comité de Dirección. En esta sección se puede acceder a cada uno de los capítulos de la memoria anteriormente citada pero no hallamos información sobre la retribución de directivos ni trabajadores.

Observamos que en la mayoría de las secciones de la web aparece una botonera para compartir el contenido en una amplia variedad de redes sociales, RSS y correo electrónico. Además de la TV a la carta y el laboratorio, en la segunda mitad de 2017 RTVE lanzó la plataforma digital Playz, en la que se ofrecen contenidos originales e interactivos de calidad como webseries, apostando por los jóvenes creadores españoles e incluyendo propuestas interactivas dirigidas al público juvenil. El Laboratorio de Radio Televisión Española (Lab RTVE) destaca por su impulso innovador en la producción de contenidos audiovisuales transmedia.

RTVE tiene un canal general en la plataforma YouTube donde hay contenidos en $360^{\circ}$, además de subcanales específicos de sus distintas secciones. Aunque no posee un canal en la plataforma Vimeo, hay colgados en ésta cerca de 3000 vídeos de programas de la corporación, también acoge un área de blogs.

La corporación española consigue 13,5 puntos de una puntuación máxima de 15 siendo sus debilidades la no actualización de su última memoria, la falta de información sobre el sueldo de sus directivos y el espacio, susceptible de mejoras que ofrece a la pluralidad y diversidad. 


\subsection{RTP}

En la sección "la empresa" de la corporación lusa encontramos la opción de abrir unas memorias (desde el año 2003 hasta el 2017) llamadas "Plan de Actividad y Presupuesto". Se tratan de extensos documentos en formato pdf en los que se dedica un epígrafe a la financiación, y otro a la justificación de la función de servicio público por cada uno de los canales de radio y de TV del grupo. En estas memorias no se especifica la retribución de directivos.

Dentro de la pestaña “Orgãos sociais" se encuentra especificado el Consejo de Administración, aunque solo aparece la foto y unas líneas sobre el currículum del Presidente, y se señala los nombres de los dos vocales. En esa misma pestaña encontramos el Consejo de Opinión, en el que sí aparecen las fotos y currículo de su presidente y todos sus miembros, así como todas las actividades realizadas por el órgano. También hay un Consejo Fiscal y un Consejo General Independiente con el mismo nivel de información que el de Opinión. Llama la atención que ninguno de los consejos tiene la misma apariencia web que los demás o lo que es lo mismo, no se da coherencia entre el contenido y la apariencia de las secciones de cada consejo.

No hay alusiones directas a la responsabilidad social corporativa, pero existe un "Relatorio de sustentabilidade" con carácter anual y otro de género. En la pestaña “Quadro Legal” se incluye el plan de prevención de corrupción, el código ético, los estatutos, las leyes nacionales que rigen la radio y la televisión e incluso la Constitución Portuguesa. Todas las secciones de la web tienen una botonera para compartir el contenido en redes sociales (Facebook, Twitter, You Tube, Instagram y Flickr). RTP no tiene blogs de colaboradores asociados a la web.

La corporación portuguesa cuenta con un laboratorio creativo y experimental, RTP Lab, con nuevas formas de producción de contenidos, pensadas en una lógica multiplataforma. También hay una sección llamada "RTP Nuestro futuro" en la que se recogen reportajes y demás contenidos sobre la naturaleza y los océanos.

RTP consigue 11 puntos de una puntuación máxima de 15, siendo sus debilidades la falta de información sobre el sueldo de sus directivos, 
programación y audiencias y el uso de herramientas de la web 2.0. como el blog.

\subsection{France Télévisions}

En la pestaña "Grupo" encontramos la información corporativa que revisa la historia, misión y un informe anual a modo de síntesis sobre balance, audiencias, cadenas, programación, gestión, creación audiovisual, digitalización, mejores momentos del año. Es un documento informativo muy completo que puede descargarse en formato pdf, pero solo está disponible el del año 2016 (no pudiéndose consultar el último, el del 2017, al final del informe se pueden consultar los correspondientes a 2014 y 2015), en esa memoria no se especifica la retribución de directivos. También hay un apartado de cifras clave en el que se sintetiza información sobre los recursos, los resultados, el capital propio o las audiencias.

Aunque no hay ningún apartado denominado responsabilidad social corporativa, en el informe anual aparecen acciones y actividades que se vinculan a esta línea. También se hace en el enlace "Ressources Humaines". En la pestaña "Organización" destacan enlaces como el del Comité de ética; a la carta ética; el Consejo de Administración y el Comité Ejecutivo. El contenido de estos enlaces se presenta a modo de noticia, explicando los nombres y los cargos o función que tienen sin fotografías individuales ni el currículo de los miembros. La pestaña "Francetelevision y vosotros" incluye enlaces al "Conseil consultatif des programmes", formado por espectadores que anualmente evalúan la programación y buscan la manera de mejorarla.

La mayoría de secciones tienen una botonera para compartir el contenido en Facebook, Twitter, YouTube, LinkedIn, Instagram, Pinterest y Google+. Cada canal dispone de sus propias redes y de un servicio de relación con el espectador (SRT), con un número de teléfono y e-mail. Además, la corporación posee un "Club del espectador", aunque no tiene blogs de colaboradores asociados a la web. France TV dispone de un Lab con varias secciones entre las que destaca Méta-media donde se abordan temas relacionados con los medios de comunicación, como las fake news. 
El ente consigue 12 puntos de una puntuación máxima de 15 , siendo sus debilidades la no actualización de su última memoria, la falta de información sobre el sueldo de sus directivos, el uso de herramientas de la web 2.0. como el blog o la ausencia de una política de responsabilidad social corporativa bien definida.

\subsection{RAI}

En la pestaña "Corporate" se ofrecen varias secciones referidas al grupo corporativo, el canon, la responsabilidad social, los proveedores, la transparencia, datos de contacto y las leyes que rigen el ente y sus medios. Incluye un apartado de "Documentos" que ofrece "Lo statuto della nuova RAI Radiotelevisione Italiana”, el contrato de servicio y el código ético.

Si se selecciona la pestaña "El Grupo" encontramos, por una parte, un organigrama anónimo del consejo de administración y el equipo directivo y un directorio alfabético de sus componentes. Por otro lado, en el apartado titulado "Bilancio" presenta, de forma actualizada, los informes anuales de la actividad económica de la corporación hasta 2017 (desde el 2011).

La pestaña "Transparenta" hace referencia a la ley que obliga a ello e incluye aspectos de gobernanza, administración y control, consejo de administración, balance, inversión en el sector audiovisual, calidad de la oferta de programación, balances, anticorrupción, recursos humanos y procedimiento para asignar contratos. En la sección "Corporate reputation e Qualitel" se publica periódicamente un balance de su reputación corporativa, en el que miden la opinión de los ciudadanos sobre todos los medios de la corporación.

En la página de inicio de la web tienen una botonera para compartir el contenido en redes sociales (Facebook y Twitter) y en un lateral de la misma aparecen los últimos contenidos twitteados por los usuarios. La corporación también acoge un área de blogs y posee un canal en YouTube que no está vinculado a la web del ente. Aunque hay una sección llamada Italia Lab en ella solo se ofrece un reproductor de vídeo que reproduce los clips más visitados.

La RAI consigue 13 puntos de una puntuación máxima de 15, siendo sus debilidades la falta de información sobre el sueldo de sus directivos, 
la información sobre su Consejo de Administración, su no vinculación a plataformas de vídeo desde la web y la falta de innovación en su laboratorio audiovisual (Lab).

\section{Comparación y síntesis de los resultados}

Sintetizando todos los resultados recabados, en la siguiente tabla se ofrece un ranking de las corporaciones analizadas según la puntuación obtenida en cada parámetro observado.

Tabla 5. Resultados totales obtenidos por parámetros

\begin{tabular}{|l|l|l|l|l|}
\hline PARÁMETRO & RTVE & RTP & France TV & RAI \\
\hline Indicadores de transparencia y gestión & 4 & 4 & 3,5 & 3,5 \\
\hline Indicadores de servicio público & 4,5 & 3 & 4,5 & 4,5 \\
\hline Indicadores uso de nuevas tecnologías & 5 & 4 & 4 & 4 \\
\hline
\end{tabular}

Fuente: elaboración propia

La tabla revela que los indicadores de transparencia y gestión son publicados por las cuatro corporaciones analizadas, aunque ninguna obtiene la máxima puntuación, al no publicar la retribución que perciben sus directivos. Las mejores puntuaciones en este ítem son ostentadas por las corporaciones española y portuguesa, aunque tanto en el caso de la española como en el de la francesa, cabe destacar que no se ha actualizado la memoria del último ejercicio (2017) estando solo disponible hasta 2016, hecho que nos parece muy grave, a pesar de que en las memorias publicadas incluyan la mayoría de los indicadores recomendados. Las radiotelevisiones estatales públicas de Italia y Francia son, a priori, las menos transparentes, en tanto que solo publican información sobre dos de los ítems, sin hacer mención a los presupuestos ni las remuneraciones de la alta dirección.

En cuanto a los indicadores de servicio público, todas las corporaciones, a excepción de la portuguesa, están cerca de conseguir la máxima puntuación ya que en sus respectivas páginas webs información sobre su código ético, actividades de responsabilidad social, estudios e informes sobre programación y audiencias, vías de comunicación bidireccionales con la audiencia y respeto a la pluralidad política y la diversidad social. La corporación lusa obtiene una 
puntuación inferior en este ítem al no facilitar el acceso a datos sobre la responsabilidad social corporativa ni de los informes sobre programación y audiencias realizados.

Por último, los indicadores que señalan el uso de las nuevas tecnologías, obtienen puntuaciones elevadas en los cuatro entes, destacando RTVE al tener un laboratorio de nuevos formatos, utilizar redes sociales y herramientas de la Web 2.0. (compartir sindicación de contenidos y blogs vinculados al medio), presencia del canal en plataformas audiovisuales (YouTube y Vimeo) y haber vinculado éstas a su sitio web.

\section{Conclusiones}

Las entidades públicas televisivas analizadas coinciden en priorizar la transparencia aportando cuantiosa información sobre su actividad, sus presupuestos y su pluralidad. En el caso italiano y portugués incluyen un apartado específico "anticorrupción" donde se explican las normativas a seguir y las medidas puestas en marcha para la prevención de esta lacra, mientras que en el resto de las corporaciones no existe una etiqueta expresa para ello.

A excepción del caso francés, en el que la información corporativa es expresada mediante gráficas y presentaciones, podemos constatar que en el resto de los entes todos esos datos son accesibles, pero presentados en inmensos documentos en pdf poco atractivos para su lectura y con escasas o ningunas herramientas de navegación, tales como un índice interactivo.

Es por ello que consideramos que es necesario seguir avanzando en este parámetro para igualar el nivel de transparencia con la ciudadanía a los de otros países europeos como por ejemplo Alemania o Inglaterra en cuyas webs se ofrece estas informaciones de forma accesible y atractiva y, no se ocultan datos necesarios para generar confianza en la ciudadanía, como la retribución de directivos y trabajadores, según su categoría o los mecanismos para el nombramiento de los primeros.

También consideramos un hecho muy grave que las corporaciones francesa y española no hayan publicado, a mediados del año 2018, las memorias corporativas del ejercicio 2017, hecho que puede redundar en la desconfianza de la ciudadanía que, en el caso de RTVE, vive sus 
momentos más críticos debido a la evidente intromisión del poder político en los contenidos informativos y al uso partidista de los órganos directivos en los últimos años.

La visualización de la función de servicio público es otro aspecto vital al que debe darse la máxima importancia, pues es el mejor justificante de la existencia de estos medios y de los beneficios que aportan a las sociedades en las que se ubican, por tanto, aspectos como el código ético, el respeto a la pluralidad y diversidad y las actividades de responsabilidad social corporativa realizadas, deben ocupar un lugar privilegiado y de fácil acceso en las webs de las corporaciones.

Todas las radiotelevisiones analizadas trabajan en entornos 2.0. con solvencia, estando presentes en las redes sociales y en plataformas audiovisuales, pero, no en todos los casos hay una vinculación visible en la web de éstas plataformas o se dispone de un blog, en el que el autor y los lectores aborden temas específicos dejando comentarios y participando en foros de discusión. Son ya muchos los medios que cuentan con ellos, ya que sirven para fidelizar a las audiencias y obtener más visitas diarias. Solo en el caso de las corporaciones española e italiana se cuenta con esta herramienta.

\section{Referencias}

Bonsón, E. y Escobar, T. (2004). "La difusión voluntaria de información financiera en Internet. Un análisis comparativo entre Estados Unidos, Europa del Este y la Unión Europea”. En Revista Española de Financiación y Contabilidad, XXXIII (123), Pp. 1063-1101.

Celaya, J. (2008): La Empresa en la WEB 2.0. Madrid: Editorial Grupo Planeta

Costa, C. \& Túñez, M. (2017). "Información corporativa online de las televisiones públicas europeas y sus relaciones con la audiencia”. En Comunicación y Medios, (36), Pp. 127-141.

European Broadcasting Union (2015): Statutes of the European Broadcasting Union. Ginebra: Technology and Innovation.

Fernández, T. y Campos, F. (2013). "La Responsabilidad Social Corporativa en las radio-televisiones públicas de Europa". En Cuadernos. Info, (33), Pp. 145-157. 
Fernández, T. (2016): "La página web como espacio de transparencia de las radiotelevisiones públicas". En Actas del III Congreso Internacional La Latina: La pantalla insomne (2 $2^{\mathrm{a}}$ edición, ampliada). Universidad de La Laguna. Pp. 526-537

Fidalgo, J. (2006): O lugar da ética e da auto-regulaçao na identidade professional dos jornalistas. Tesis doctoral. Minho: Universidade de Minho.

López, A. M. y Manfredi, J. L. (2013). “Análisis de la transparencia de las páginas web de los principales medios de comunicación audiovisuales en España". En Trípodos, 1(32), Pp. 45-62

Madinabeitia, E. (2010): "La publicidad en medios interactivos. En busca de nuevas estrategias". En Telos: Cuadernos de Comunicación, Tecnología y Sociedad, (82), Pp. 43-54.

Manfredi, J.L. (2011). "Escenarios y retos de la televisión pública en España”. En AdComunica. Revista de Estrategias, Tendencias e Innovación en Comunicación, (1), Pp. 49-62.

Martí, D., Álvarez, M. L. y Domínguez, S. (2010). "Reputación y responsabilidad desde webs corporativas". En Área Abierta. Revista de comunicación audiovisual y publicitaria, (26), Pp. 1-22.

Monedero, C.R. (2013): "Presencia de las televisiones municipales en redes sociales e Internet como nueva vía de conexión con la audiencia: el caso de la Comunidad Andaluza". En Actas del V Congreso Internacional Latina de Comunicación Social. La sociedad ruido. Entre el dato y el grito. Universidad de La Laguna. Pp. 1364-1388.

Pérez, S., Goyanes, M, Paniagua, F. (2018): "La innovación en la rendición de cuentas de los medios de comunicación de servicio público (PSM). El caso de la CCMA”. En Revista Latina de Comunicación Social, (73), Pp. 1115-1136.

Túñez, M. y Sixto, J. (2011). "Redes sociales, política y Compromiso 2.0: La comunicación de los diputados españoles en Facebook". En Revista Latina de Comunicación Social, (66), Pp. 210-246.

\section{Reconocimientos de la investigación}

Esta investigación ha sido financiada por el Departamento de Periodismo de la Universidad de Málaga. 


\title{
Cobertura informativa de procesos electorales: innovación y oportunidad de un servicio público esencial
}

\author{
Fermín Galindo Arranz \\ Juan Carlos Regueira Rey \\ Universidade de Santiago de Compostela
}

PARA CITAR: Galindo Arranz, F. y Regueira Rey, J. C. (2018). Cobertura informativa de procesos electorales: innovación y oportunidad de un servicio público esencial. En Rodríguez-Castro, M., Pérez-Seijo, S. y Campos-Freire, F. (Eds.). La TV Pública en Europa: Innovación, Retos y Tendencias (89-109). Cuadernos Artesanos de Comunicación, cac 146. La Laguna (Tenerife): Latina. DOI: $10.4185 /$ cac146.

\section{Resumen}

Ante las próximas elecciones al Parlamento Europeo de mayo de 2019 - entre otras convocatorias electorales - las televisiones públicas tienen la oportunidad de brindar un servicio público de calidad. La tradicional cobertura informativa de los procesos electorales está regulada jurídicamente de forma minuciosa y supone un esfuerzo presupuestario esencial y extraordinario. La importancia de las mencionadas convocatorias, por tanto, tiene un impacto cuantificable en las diferentes fórmulas de evaluación del servicio público y su coste de ejecución. El estudio continuado de estas coberturas permite vislumbrar una oportunidad para la innovación, en un momento en el que se aúna el máximo interés informativo con la trascendencia inmediata de los resultados electorales. 
Palabras clave: televisión pública, generalista, elecciones, informativos, presupuesto, innovación, realidad aumentada, CRTVG, servicio público.

\section{Introducción. Información electoral, un servicio público esencial}

Desde hace varias décadas la reflexión sobre el papel de las televisiones públicas ha centrado un esfuerzo importante de la comunidad académica. Pere-Oriol Costa (1986: 353) reflexionaba en los ochenta acerca de la crisis a la que debían hacer frente las televisiones públicas ante la necesidad de salvaguardar un espacio de servicio público dada la apertura comercial imparable del espectro audiovisual. En la misma dirección, Jay G. Blumler (1994: 21) de la Universidad de Leeds ya veía entonces a la televisión pública como una "querida abuela" y se preguntaba: ¿puede la televisión pública sobrevivir y prosperar en la Europa occidental? Para él, era esencial que los responsables de la televisión pública definieran de manera explícita y elaborada las formas particulares de servicio público que intentan emitir en el futuro, incluyendo con cierto detalle especificaciones sobre sus implicaciones en la programación. Para Blumler esto debería estar asociado con "un sistema de planificación que sitúe los objetivos de actuación correspondientes y que monitorice, evalúe y públicamente informe si, y en qué medida, se han cubierto tales objetivos".

Un tiempo después, la última crisis y el proceso de digitalización han causado un gran impacto sobre el sistema mediático. En este nuevo contexto Moragas y Garitaonandia $(2012,16)$ han señalado que resulta complicado justificar ingresos crecientes para las radiotelevisiones públicas ante la necesidad de hacer frente a nuevas demandas: "que sean innovadoras, de forma que integren internet, redes sociales, telefonía móvil o que hagan programas cross-media, incluso con menores recursos". A veces incluso la crisis es utilizada ideológicamente para justificar descensos en la financiación de los medios públicos. El propio balance de las radiotelevisiones públicas autonómicas destaca su función de servicio público, de dinamización de su entorno, de vertebración social, de soporte cultural y lingüístico, de promoción del 
turismo y de innovación con nuevos formatos, desarrollo de ficción propia, introducción de servicios on line, bajo demanda y a la carta, alta definición y la contribución a la industria audiovisual de su entorno. En síntesis, el problema según Campos (2012, 160) "radica en cuantificar el coste inversión del servicio público en cada Comunidad". A continuación, se trata de mostrar y analizar, a través de un estudio piloto, la labor de las televisiones públicas en general y de las autonómicas en particular, a la hora de realizar la cobertura informativa de un proceso electoral entendido como un servicio público esencial.

\section{Metodología aplicada}

A partir de los tres pasos señalados por Blumler se trata de observar: la implicación habitual de una televisión autonómica en la programación de un proceso electoral, la planificación de sus objetivos de producción y emisión y, finalmente, el seguimiento, monitorización y evaluación de un servicio público esencial como la información electoral. En este sentido, y ante las próximas elecciones al Parlamento Europeo de mayo de 2019 -entre otras convocatorias electorales-, las televisiones públicas tienen la oportunidad de brindar un servicio público de calidad.

El despliegue informativo de las televisiones públicas en los procesos electorales está regulado jurídicamente de forma minuciosa y supone un esfuerzo presupuestario ineludible, que no por repetido deja de ser extraordinario. La importancia de las mencionadas convocatorias, por tanto, tiene un impacto cuantificable en las diferentes fórmulas de evaluación del servicio público y su coste de ejecución. El estudio continuado de estas coberturas también permite vislumbrar una oportunidad para la innovación, en un momento en el que se aúna el máximo interés informativo con la trascendencia inmediata de los resultados electorales.

Desde la transición, el contenido político de la programación de radios y televisiones públicas españolas ha estado regulado de forma específica durante las campañas electorales. La emisión de lo que con el tiempo se ha dado en llamar géneros políticos, está sometida a estrictos controles legales, a través de las juntas electorales, con el fin de garantizar la neutralidad informativa y la pluralidad social y políticas propias de un estado de derecho. El marco legal condiciona, por tanto, 
de forma imperativa, a los medios públicos en la cobertura informativa diaria de la campaña y, también, la programación electoral en su conjunto.

A partir de la experiencia acumulada en las últimas décadas, en este texto se avanza una prospectiva aplicada sobre la cobertura informativa de las Elecciones al Parlamento Europeo de 2019. La simultaneidad de convocatorias electorales: municipales, provinciales o autonómicas en otras circunscripciones no hacen sino aumentar la complejidad de la atribución de tiempos a los diferentes actores políticos en las distintas ventanas que a tal efecto brinden las emisoras públicas. Baste señalar, como explica Blanco (2011, 30), que siempre acompañan a las elecciones municipales las de las trece comunidades autónomas de la vía general; todas, excepto las de la vía especial: Euskadi, Cataluña, Galicia y Andalucía. Por imperativo legal, todas las radios y televisiones públicas deben incluir puntualmente información sobre estos escenarios, sin olvidar la información internacional, aunque, eso sí primando la información de proximidad. En las próximas elecciones, por tanto, la cobertura informativa tendrá que seguir pautas similares a las que han marcado las últimas convocatorias a las urnas.

Esta reflexión se apoya en la cobertura específica realizada por una televisión pública autonómica, la CRTVG, a lo largo de la última década y de la experiencia acumulada en el estudio de campañas electorales en los últimos años en la USC. Se avanza una prospectiva de cobertura de forma genérica, sin entrar al detalle concreto de producción, con el fin de entender los costes asociados a un servicio público esencial y la oportunidad de innovación que suponen dentro de la rutina informativa de cualquier cadena. Se trata, por tanto, de un análisis trenzado entre la experiencia adquirida en la producción audiovisual de este tipo de eventos y la crítica académica de una experiencia repetida en el tiempo y que comporta una parte esencial del servicio público a la ciudadanía.

A diferencia de investigaciones anteriores, en esta se incide en el coste y oportunidad que supone para las televisiones públicas la cobertura informativa de procesos electorales. Este tipo de eventos supone un enorme despliegue de recursos humanos, técnicos y económicos con una influencia directa sobre la cuenta de resultados. También supone una oportunidad para los profesionales del medio, al tener que hacer 
frente a retos periodísticos poco habituales en la programación ordinaria.

En estos últimos años los especiales electorales de la Televisión de Galicia han destacado por varias razones: han logrado unos buenos resultados de audiencia liderando la cobertura informativa del resto de los medios; han buscado la excelencia intentando evitar los errores informativos que en ocasiones se han cometido en base a diferentes factores; han asumido un discurso innovador y creativo en lo tecnológico que, a su vez, ha servido para dar respuesta a la natural expectación del momento. Se trata, por tanto, de abordar un asunto ya conocido desde un punto de vista diferente. Entender que de la misma forma que el patrimonio público, especialmente escuelas y colegios, se ponen a disposición de la participación ciudadana en una convocatoria electoral, las televisiones públicas también realizan un esfuerzo extraordinario para dar cobertura en su programación a los procesos electorales. A pesar de todo y de forma reiterada no suelen ser considerados como eventos especiales en algunos informes de servicio público. Se trata de analizar esta situación a partir de las consideraciones a tener en cuenta para la elaboración de un piloto de producción del operativo técnico, humano y presupuestario para hacer frente a un despliegue televisivo extraordinario.

Además, las televisiones públicas compiten habitualmente con el resto de los medios en la emisión y valoración de las campañas electorales y en especial en ofrecer, de la mejor forma posible, los resultados finales. Todas las cadenas tratan de atraer la atención de los espectadores, aunque, debido a su elevado coste, algunas de ellas tratan de ajustar su parrilla evitando determinados gastos. En este punto las televisiones públicas tienen algunas ventajas competitivas vinculadas a la credibilidad de los resultados como fuente oficial de las noticias, a la calidad técnica de sus conexiones, a la sintonía existente entre una convocatoria electoral y su ámbito de influencia o al know-how acumulado por plantillas experimentadas, entre otras.

Al final, los resultados suelen ser llamativos por la reiterada demostración de confianza de la audiencia en este tipo de ocasiones especiales, y los resultados de unas elecciones lo son. Baste señalar que TVG suele situar estos programas como líderes en su franja, y es habitual que sitúe su audiencia por encima del 30\% de share. En este 
sentido, la convocatoria electoral, ya prevista, de finales de mayo de 2019 no ha de ser una excepción. El punto de partida es, por consiguiente, una situación óptima para buscar el liderazgo y la innovación audiovisual.

\section{Marco jurídico y programación electoral: géneros políticos}

El entramado legislativo y normativo que articula el tratamiento informativo de los procesos electorales arranca de la Constitución y se ha ido actualizando en las distintas convocatorias electorales a partir de las sentencias de las Juntas Electorales.

Las televisiones públicas cuentan con un departamento jurídico que se encarga de proponer la aplicación de estas pautas en el marco de la LOREG, de la Constitución y de la doctrina emanada de la Junta Electoral Central en relación a la actuación de los medios de comunicación públicos.

Los canales públicos quedan sometidos además a sus propias leyes de creación. Este ordenamiento se traduce en que las televisiones públicas deben propiciar el acceso de los grupos políticos significativos a los medios de comunicación de titularidad pública. En este sentido, el Consello de Administración de la Compañía de Radio Televisión de Galicia CRTVG establece el tratamiento mediante un plan de cobertura específico en cada convocatoria electoral. Este documento regula todo lo relativo a los espacios gratuitos de propaganda electoral y a la "difusión de campañas institucionales, programas especiales de comienzo y cierre de campaña, así como los debates y entrevistas a candidatos, junto a la cobertura diaria en los espacios informativos".

A partir de esta práctica continuada en el tiempo se produce lo que se ha denominado Ley D'Hont de la Televisión (Galindo: 1998, 93-107). El sistema electoral proporcional condiciona de forma decisiva a los votantes a utilizar su voto en apoyo de mayorías políticas, y castiga la expresión de una realidad política más plural en especial en las pequeñas circunscripciones. Los mecanismos unificadores dentro del propio sistema se ven acrecentados por el acceso a los consejos de administración y a la reiterada asignación de espacios de propaganda a partir de resultados anteriores. En consecuencia, se produce un efecto de reiteración de sesgos inherentes a la aplicación de la LOREG. Con 
el fin de compensar esta situación, la Junta Electoral Central se ha tenido que pronunciar (Instrucción 1/2015 de 15 de abril de 2015) para dar cabida a nuevas formaciones emergentes carentes de representación política anterior y que "en recientes procesos electorales y en el ámbito territorial del medio de difusión, hayan obtenido un número de votos igual o superior al 5\% de los votos válidos emitidos".

\section{Planificación y objetivos de producción y emisión. Prospectiva de las elecciones al Parlamento Europeo de 2019}

Desde la transición, el contenido político de la programación de radios y televisiones públicas españolas ha estado regulado de forma específica en periodos electorales. La emisión de los géneros políticos está sometida a estrictos controles legales con el fin de garantizar la neutralidad informativa y la pluralidad social y políticas propias de un estado de derecho. El marco legal condiciona de forma decisiva a los medios públicos en la cobertura informativa de la campaña y en la programación electoral en su conjunto. La información es cronometrada y ajustada al segundo entre los diferentes partidos. Las emisiones deben atenerse a la cobertura electoral previamente fijada y a las normas derivadas de la legislación específica vigente. Estas pautas se convierten, por consiguiente, en una suerte de exoesqueleto con el que debe caminar la información diaria a lo largo de la campaña. La junta electoral vigila que estas normas se cumplan, resuelve las dudas que puedan surgir sobre la marcha, y garantiza que la emisión informativa en un proceso electoral de las televisiones públicas se ajuste a derecho, que se debe atener en tiempo de campaña a los ya mencionados requerimientos legales.

\subsection{Emisión general y desconexiones locales.}

El precepto fundamental que rige la información electoral en tiempo de campaña es el de neutralidad y pluralismo en los medios, traducido en una asignación de tiempos proporcional a la representación anterior en elecciones equivalentes de cada formación política. Como ha señalado Vilas Nogueira (1998, 33), la tribuna habilitada para el público en los parlamentos se ha ampliado y proyectado a través de todos los medios. La televisión, además, ha propiciado un efecto de personalización política que ha trasladado el debate parlamentario a los 
medios de comunicación propiciando que el tratamiento informativo del líder, o cabeza de lista en período electoral, pasa a ser el del partido y viceversa.

La cobertura de una televisión autonómica como CRTVG solventa sus desconexiones aplicando la proporcionalidad a los resultados de cada demarcación. Se han de prever, por tanto, unas ventanas con un tiempo pautado por formación y territorio de desconexión a lo largo de la campaña. Estos segmentos se suelen incluir como colas informativas con cabeceras o cortinillas propias dentro de los espacios informativos diarios. Es decir, aparece una cobertura específica por cada una de las convocatorias electorales que se celebran. También se informa con criterios de proporcionalidad de los comicios que afectan a otras zonas y que se celebran simultáneamente, como en las elecciones europeas, en el caso de otros países, o de las elecciones en otras comunidades autónomas. En el caso de TVG, se suelen habilitar cinco cabeceras de desconexión de cinco minutos: A Coruña y Ferrol, Santiago, Lugo, Ourense y Pontevedra-Vigo. Las emisiones da Coruña / Ferrol e Pontevedra / Vigo son conjuntas y su duración dobla la de las tres restantes.

\subsection{Programas especiales producidos en plató}

Por su propia naturaleza, el discurso audiovisual debe ir asociado a la novedad. La estética de los platós debe ser renovada cada cierto tiempo con el fin de atrapar y sostener el atractivo visual para el público. La propuesta de programación electoral ha de contener, por tanto, aportaciones originales y con proyección futura, ya que no es otra cosa que el porvenir inmediato de todos lo que está en juego. Algunos autores (Contreras y Palacio: 2003, 20) afirman que "la televisión es novedad y es evidente que en este concepto se incluye la aceptación de los innumerables riesgos que todo proceso de experimentación arrastra". En este caso, la innovación parece, de forma paradójica, impulsada por las restricciones legales a las que está sometida la cobertura informativa electoral. La competencia por una audiencia cada vez más dinámica, en un marco tan regulado lleva a buscar soluciones imaginativas de programación. Se trata de hacer compatible la filosofía de servicio público, la calidad de la programación y el éxito de crítica y público. Parece imposible, pero ya se ha logrado en 
ocasiones anteriores. Las televisiones públicas en periodo electoral están sujetas a un escrutinio público permanente y ven limitada su habitual discrecionalidad partidaria. Fiscalizadas por las juntas electorales, tienden a dejar en manos de sus propios profesionales la aplicación concreta del mandato legal de neutralidad y pluralidad.

En un piloto para el 2019 deben reservarse instalaciones, platós, personal, tiempo de grabación y espacios para la emisión de todos los géneros políticos. Cuando las elecciones son múltiples, las reservas para entrevistas o debates se multiplican y los costes se disparan. Hasta ahora la TVG ha optado por producir siete debates de ámbito local, que se corresponden con las áreas metropolitanas antes explicadas, con duraciones superiores la hora de programación y destinados a su emisión en las ventanas de desconexión. Eso sin contar otros posibles debates, ya sean de alcance autonómico, sobre las diputaciones, las elecciones europeas, incluso con otras posibles convocatorias que pudieran coincidir ese mismo día.

\subsection{Programas especiales no producidos en plató}

En este epígrafe se incluyen los programas de cobertura autonómica, los especiales de apertura y cierre de campaña, o de los festivos incluidos en la campaña con un mayor tiempo de emisión por la dimensión de los actos programados. Son actos que incluyen las tradicionales pegadas de carteles y actos de apertura, los grandes mítines o los actos de cierre de campaña que exigen conexiones en directo con los diferentes puntos de la geografía elegidos por cada partido. Sus horarios vienen marcados por el comienzo y final de la campaña, o por otras circunstancias, como la presencia en Galicia de líderes nacionales o la publicación de las últimas encuestas electorales a una semana de la jornada electoral. Estos especiales son ejecutados por los equipos de redacción, producción y realización de los informativos diarios reforzados durante el periodo electoral.

\subsection{Desarrollo y diseño de los contenidos y de la producción}

Todos los géneros políticos que se incluyen en la programación electoral deben ser objeto de una planificación específica que requiere un considerable esfuerzo de producción con el fin de incorporar las innovaciones que se programen a tal efecto. A continuación, se realiza 
una somera descripción de acciones a realizar, siempre susceptibles de aumentar, dada la importancia del momento.

Ante una convocatoria electoral prevista para la última semana de mayo, los equipos de producción y dirección de contenidos comienzan a trabajar con un mínimo de tres meses de anticipación -normalmente desde enero- para fijar las pautas estéticas, operativas y de contenidos de una programación especial diseñada para cubrir el desarrollo de la campaña electoral de acuerdo con los plazos y el reparto de espacios que acuerde el Consello de Administración de CRTVG. Esta fase es fundamental para poder fijar los objetivos que permitan competir con el resto de las cadenas. La filosofía habitual consiste en acentuar la información de proximidad con una apuesta tecnológica de última generación, en la actualidad marcada por una nueva cultura digital corporativa en evolución constante.

A las siete grandes ciudades se suma el especial seguimiento de catorce villas medianas de las cuatro provincias y la información actualizada de los municipios más pequeños. Este despliegue es inalcanzable para el resto de los operadores y una ventaja competitiva decisiva. Por ejemplo, solo para la realización de las entrevistas electorales se moviliza una cantidad ingente de recursos humanos: presentadores, realizadores, iluminadores, operadores de cámara, técnicos, personal de maquillaje y peluquería, montadores, técnicos de sonido, estilistas, personal de prensa y relaciones públicas, redactores, mezcladores de vídeo y todo tipo de especialistas y directivos con los que cuentan los medios públicos.

El segundo concepto fundamental es la gestión del flujo informativo en pantalla. En la noche electoral, los resultados electorales se suceden a un ritmo vertiginoso a medida que se van escrutando las diferentes mesas electorales, el baile de resultados y por tanto de posiciones ganadoras está garantizado. Dar salida a una corriente informativa tan sensible e inmediata es un reto profesional de primer orden. La inesperada aparición de nuevos datos y gráficos se convierte en una suerte de fuegos artificiales con los que finaliza la campaña y comienza un nuevo mandato. La actualización permanente de las pantallas, con una renovación inmediata de los resultados de las distintas convocatorias es una exigencia ineludible. La escaleta debe estar cuidada hasta el mínimo detalle y presentar una transparencia total en 
el discurso audiovisual, convirtiendo la señal de la cadena pública en la información de referencia del momento. La aportación de expertos debe ayudar a interpretar lo que sucede. Es un tiempo para la información y no para el análisis casi siempre interesado en establecer una lectura partidista de los resultados. En síntesis, la innovación suele ir vinculada a tres elementos sustanciales: a una nueva escenografía, a un tratamiento rápido y riguroso de la información y a una estética cuidada del relato audiovisual.

\subsubsection{Escenografía: set físico y augmented reality graphics}

Se trata de mostrar los resultados de las distintas convocatorias de una forma atractiva y ágil. Con anterioridad, TVG ha optado por una escenografía híbrida en la que se mezclan los gráficos con la imagen real creando una ilusión óptica integral con la escenografía del estudio. Los gráficos utilizados se conocen como augmented reality graphics y son una solución tecnológica de reciente implantación, por lo que se hace preciso recurrir a un proveedor tecnológico externo mediante concurso público. En ocasiones anteriores, TVG ha contado con colaboración de la portuguesa WTVision (encargada de los grafismos de Eurovisión 2017) y que cuenta con un know-how contrastado en esta especialidad.

El conductor del programa sincroniza sus movimientos entre gráficos de barras e imágenes dando la sensación que el presentador puede tocarlos. Las imágenes se superponen a través de un potente sistema informático que recoge los resultados oficiales del Ministerio del Interior y los transforma en gráficos limpios y fluidos que aparecen en pantalla en tiempo real. El diseño del decorado debe tener en cuenta estas circunstancias para alcanzar un acabado depurado e integrador entre ambas realidades, además de ser compatible con otros soportes y canales.

\subsubsection{Una información rigurosa e inmediata}

Desde hace una década se viene utilizando la tecnología tapeless, sin cintas para el almacenamiento y gestión inmediata de la información audiovisual. Se usan servidores de vídeo que cuentan con loop recording o grabación en bucle, lo cual permite ir editando fragmentos de las múltiples comparecencias sin dejar de grabar. La audiencia puede asistir 
a las declaraciones más interesantes y ver también otros momentos, aunque se produzcan de forma simultánea. Su impacto en el workeflow de cualquier redacción televisiva es tal que la CRTVG consideró oportuna su adquisición y ahora ya es parte de su dotación técnica habitual. Dicha decisión económica vino dada, en gran medida, por su papel decisivo en la cobertura de las jornadas electorales.

\subsubsection{Unificación gráfica}

A lo largo de toda la campaña resulta de vital importancia la imagen gráfica de los protagonistas. Cada partido apuesta por la suya, todas ellas diferentes con el fin de hacer valer la imagen de su candidato. En la noche electoral es conveniente unificar todas ellas bajo la misma estética que garantice un resultado homogéneo del relato informativo. Esta acción requiere de un concurso público al efecto y permite contar con fotografías de recurso de los actores y de las distintas localidades.

\subsection{Pre-producción}

Una vez diseñada la estética de la cobertura se pasa la fase de preproducción que prevé los distintos preparativos para la ejecución de los programas con el fin de plasmar los contenidos decididos conjuntamente por los equipos editoriales, de realización y producción en la etapa de gestación y desarrollo del proyecto. Corresponde al equipo de producción poner en marcha todos los operativos previstos, la elaboración del calendario y presupuesto de producción, la elección de los proyectos tecnológicos y escenográficos, las previsiones para el despliegue de recursos técnicos y humanos precisos y la posterior ejecución de los programas.

La pre-producción está condicionada por unos requisitos legales, ya explicados, que condicionan la forma de trabajar. Es el momento de evaluar necesidades y plazos. La colaboración de los partidos es esencial en este punto ya que las decisiones que se toman en ese momento son las que van a garantizar la viabilidad del proyecto. Se pueden enumerar una decena de acciones habituales en todos los procesos. 


\subsubsection{Elaboración del calendario de producción}

El equipo de producción debe hacer públicos los calendarios y planes de trabajo para alcanzar una buena coordinación con el resto de los departamentos implicados en el despliegue operativo. El primer paso es cuadrar los calendarios de montaje y producción de los platós utilizados para la grabación de los diferentes géneros políticos habituales programados y los posibles programas especiales. La rutina de trabajo queda establecida el mes anterior al comienzo de la campaña electoral.

\subsubsection{Puesta en escena: línea gráfica y decorados}

El departamento de diseño gráfico de la CRTVG se encarga de elaborar una primera propuesta de línea estética con el fin de unificar la escenografía que se vaya a utilizar en la campaña, así como en los elementos de imagen corporativa, cabeceras, promos y cortinillas. La propuesta debe incluir el grafismo on-air como elemento de decorado físico que aparecerá unificando todos los programas electorales grabados en plató. Este tipo de trabajo suele ser realizado por algún estudio externo colaborador habitual del departamento de diseño gráfico de la compañía. El diseño de los nuevos sets suele ser innovador acorde con la estética del momento. Conviene resaltar que la decisión logística de utilizar uno o varios sets viene dada por la necesidad de utilizar espacios diferenciados que ayuden a agilizar el relato informativo y la producción de la campaña en su conjunto.

\subsubsection{Plató principal}

Este espacio opera como central de datos en la jornada electoral. Es un plató que suele estar dividido en dos sets independientes, pero que en campaña se suelen utilizar ofreciendo una continuidad visual. Aun así, se puede utilizar para implementar escenografías virtuales en su modalidad de augmented reality en los programas emitidos en las noches electorales y en los resúmenes incluidos en los informativos postelectorales del día siguiente. 


\subsubsection{Plató de apoyo}

Si el plató principal centraliza el recuento electoral virtual, el plató de apoyo se suele utilizar para los debates electorales, ya sean ordinarios o sectoriales, y para la realización de las entrevistas a los cabezas de lista que suele contemplar la resolución marco del Consello de Administración de la CRTVG. En el especial de la noche electoral también se puede habilitar como mesa de análisis o set de segunda lectura de los resultados.

\subsubsection{Sondeos electorales propios y ajenos}

La contratación de sondeos por las televisiones públicas se ha convertido en habitual en las últimas convocatorias electorales. La crisis ha impuesto un criterio de austeridad a la mayoría de los actores que intervienen en el proceso electoral, que prefieren esperar a la aparición de resultados oficiales. La FORTA contrata mediante concurso público un sondeo conjunto de las televisiones autonómicas con el fin de realizar sus propias proyecciones de datos al cierre de los colegios electorales. Los departamentos de informática de la TVG, junto al proveedor de gráficos virtuales y la empresa de sondeos, comienzan a trabajar con semanas de antelación para poder implementar en directo, al cierre de los colegios electorales, el sondeo contratado. Son equipos experimentados y que han realizado este tipo de cobertura en varios comicios.

\subsubsection{Concurso público grafismo on-air}

En el caso de que la cadena decida contar, como en otras ocasiones, con un proveedor de grafismo on-air, se convoca un concurso público al efecto. En campañas precedentes resultó adjudicataria la empresa portuguesa WTVision, del conglomerado Medialuso. Su aportación suele resultar la más visible de las innovaciones tecnológicas aplicadas a la cobertura de campañas electorales ya que son líderes mundiales en este campo. Este proveedor desplaza a las sedes de sus clientes un potente dispositivo de hardware y software gráfico de última generación y un equipo habitual con una decena de especialistas. La parte más visible de este proceso es la inclusión de gráficos en 3D en una escenografía tipo augmented reality y con un flujo constante y dinámico de datos. 
También conviene destacar la ya tradicional incorporación de una banda gráfica adicional o ticker con información permanente de los resultados de la totalidad de los 315 municipios con los que cuenta Galicia. Es una solución gráfica de extraordinaria eficacia y muy bien valorada por la audiencia dada la dispersión poblacional de Galicia.

\subsubsection{Elección del proveedor de imagen fotográfica}

Este es un apartado a tener en cuenta. Con la intención de unificar la estética formal de los candidatos se suele contactar con reconocidos fotógrafos para que envíen sus propuestas. El profesional elegido organiza las sesiones con los candidatos para contar con una propuesta homogénea y en formato digital de todos los protagonistas que la cadena incorpora a su propio archivo. Estas imágenes también pueden ser utilizadas para ambientar otros géneros políticos y canales de la corporación.

\subsubsection{Elección de los proveedores de diseño y construcción de decorados}

La previsión de una cita electoral como las próximas elecciones al Parlamento Europeo 2019 (previstas para la última semana de mayo) permite trabajar con tiempo y de acuerdo con el calendario de producción establecido a la hora de construir unos decorados con un alto acabado visual, tanto en materiales (pintura, metacrilatos, impresiones de vinilo, maderas) como en el apartado estético. Las empresas colaboradoras habituales forman parte del entorno de la CRTVG y son las mismas que suelen colaborar en la renovación los sets de otros programas de la cadena. La continuidad estética global de la imagen de la corporación queda así garantizada.

\subsubsection{Localización previa de puntos de directo}

El equipo de producción debe realizar una serie de localizaciones previas para preparar las conexiones en directo. Habitualmente se realiza una ficha de cada punto de directo que incluye fotografías de accesos y posibles ubicaciones de las estaciones transportables y las nuevas mochilas 4G. Este trabajo previo es de suma importancia en la jornada electoral en la que el tiempo apremia y en la que es habitual contar con hasta diez de equipos de transmisión para hacer las 
correspondientes conexiones en directo con colegios electorales, centros de datos, sedes y otras localizaciones habilitadas al efecto por los partidos políticos.

\subsubsection{Imprevistos}

La propia evolución de la campaña o los acuerdos vinculantes de las juntas electorales pueden llevarnos a tener que utilizar otros medios, enlaces y soluciones, no previstas inicialmente, pero a las que poder recurrir ante la aparición de imprevistos en especial con la rápida evolución de la nueva cultura digital.

Una vez contratados todos los proveedores y establecidos los plazos de ejecución de sus servicios, comienza el periodo en el que el equipo de producción prepara los planes de trabajo de los equipos técnicos para la realización de los programas y se hacen las reservas pertinentes para la emisión de espacios en directo.

\subsubsection{Debates (plató de apoyo)}

A diferencia de los grandes debates-show, los debates de menor formato también están previstos en todas las convocatorias. Las grabaciones deben preservar la igualdad entre los contendientes con el fin de evitar filtraciones. También se pueden inclinar por realizar finalmente los debates en directo. La producción debe tener en cuenta ambas posibilidades.

\subsubsection{Entrevistas (plató de apoyo)}

La actual atomización política lleva a pensar un mínimo de cinco representantes por cada contienda electoral, solo entre las siete grandes ciudades ya estamos en una previa superior a la treintena de entrevistas. Las entrevistas han de realizarse en campaña y prácticamente en las mismas fechas. La reserva de medios técnicos y humanos es imprescindible.

\subsubsection{Training para el manejo de servidores y nuevas tecnologías}

El equipo de producción debe tener previstas jornadas de training de última hora para operadores y periodistas con el fin de hacerse con el manejo de los nuevos equipos que se incorporarán a lo largo de la 
campaña. Con anterioridad estas jornadas fueron muy útiles, por ejemplo, en la formación del interfaz de aplicaciones EVS, una solución de registro, almacenamiento y reproducción instantánea que pemitió superar el farragoso esquema habitual de trabajo con cintas en las cabinas de edición de informativos. La previsión de nuevas soluciones y el actual proceso de digitalización exige la programación de jornadas de formación.

\subsubsection{Ubicación proveedores externos}

La llegada de personal y hardware de proveedores externos supone un reto que hay que tener previsto para su adecuada integración en el operativo técnico de la TVG. Los expertos de las empresas externas deben integrarse con los técnicos de los platós y de los controles de realización. En ocasiones anteriores el hardware de WTVision y los servidores EVS se han ubicado en las proximidades del control debido a la necesidad de cablear los nuevos servidores para conectarlos al control de realización. Es una implementación tecnológica que ha de estar testada con anterioridad.

\subsubsection{Reserva de segmento espacial de tráfico y señales externas}

El departamento de retransmisiones realiza con antelación la reserva de segmento de satélite y conexiones para cubrir las necesidades de campaña, ya que se debe garantizar el servicio a las estaciones transportables a gestionar durante la jornada electoral. Además de los puntos habituales de conexión en directo de apertura o de cierre de campaña, el equipo de producción debe gestionar múltiples señales externas, próximas a la veintena dependiendo de la capacidad técnica del equipo. Con circuitos y órdenes desde diferentes puntos de Galicia, Madrid, Bruselas o de otros centros de recuentos de datos.

\subsubsection{Ensayos previos y jornada electoral}

Los grandes debates exigen ensayos previos y procelosas negociaciones con los equipos de campaña de los candidatos. La escaleta básica de contenidos también debe ser testada con anterioridad. La incorporación de un discurso complejo con numerosas fuentes de todo tipo exige la formación de equipos experimentados y ágiles que den respuesta inmediata a vuelcos electorales y situaciones inesperadas. 
Combinar, por ejemplo, gráficos en 3D en el set de augmented reality exige la presencia del conductor del programa, del equipo de realización, de los técnicos de gráficos externos y del personal de apoyo necesario para que todo fluya adecuadamente. Las jornadas de preparación y ensayo deben estar, por tanto, incluidas en la planificación de la cobertura de la campaña.

\subsubsection{Reserva de ancho de banda extra para la web de CRTVG}

Es necesario prever ya en la fase de pre-producción una reserva de ancho de banda extra que permita soportar un mayor tráfico de datos derivado del streaming de la emisión en directo y de vídeos bajo demanda relacionados con la jornada electoral. La previsión de accesos masivos debe contemplar la importancia de mantener activa la web corporativa y soportar con holgura el previsible aumento de la demanda de contenidos audiovisuales en la jornada electoral.

La dinámica de la campaña puede que lleve a utilizar otros medios, enlaces y soluciones, no previstas inicialmente, pero a las que recurrir ante la aparición de imprevistos, en ocasiones, de obligado cumplimiento, como acuerdos de las Juntas Electorales, en especial con la rápida evolución de la nueva cultura digital.

\section{Seguimiento y evaluación del procedimiento.}

Los programas más seguidos por la audiencia suelen ser los grandes debate-show, con gran participación en redes sociales y motivo de discusión central en campaña y en la opinión pública. Conforman en algunos momentos una suerte de comunidad en la que convergen usuarios, espectadores, oyentes que serán finalmente electores. Las televisiones públicas son el escenario natural de este tipo de eventos.

El otro momento estelar son las noches electorales. Las próximas elecciones de 2019 no serán una excepción. Con una adecuada preparación y teniendo en cuenta el masivo seguimiento de retransmisiones anteriores deben aspirar a producir y emitir uno de los programas más visto del año. La cobertura informativa electoral constituye una gran inversión de tiempo y esfuerzo recompensado por la fidelidad del público. El histórico de audiencias de este tipo de 
especiales demuestra que se trata de un comportamiento asimilado y que se repite en el tiempo.

La prensa no suele ser ajena a esta realidad, aunque suele pasar un tanto desapercibida ante la novedad de los resultados electorales y sus futuras consecuencias. Las cifras récord alcanzadas por este tipo de programas demuestran la trascendencia social de sus contenidos y la alta valoración del trabajo realizado. Una vez detallado el esfuerzo de producción se puede entrar a valorar si en su conjunto constituye o no un evento extraordinario. Los estudios académicos han mantenido una preocupación constante por el devenir del sector público audiovisual; ahora, tal vez estén más orientados a la definición del concepto de servicio público y sus diferentes variables. La participación de los medios públicos en los procesos electorales se entiende, a tenor de lo aquí expuesto, que puede ser una de ellas

\section{Conclusiones}

Después de analizar detenidamente los múltiples factores que afectan a la cobertura informativa de procesos electorales, cuantificamos una serie de gastos extraordinarios que se suelen aproximar al 1\% del presupuesto anual de la cadena. Se trata, como ha quedado demostrado, de un servicio público esencial y en el que entra en juego la propia autoestima del medio, incluso del propio sistema democrático. Conviene, por tanto, entender el imponente esfuerzo presupuestario, técnico y humano que supone la adecuada cobertura de una campaña electoral. También, del rédito público que supone hacerlo adecuadamente.

La primera evidencia: las cifras de audiencia alcanzadas por estas emisiones en comicios anteriores demuestran el interés por las elecciones y la importancia del momento en el que se conocen los resultados. Cada vez son más canales, plataformas, redes, dispositivos y soportes los que compiten por la atención y ofrecer las novedades a sus usuarios. La fuerza de la imagen es definitiva y la atención que se reserva en la noche electoral para la gran pantalla, hasta ahora también lo ha sido. La importancia de alcanzar unos buenos resultados es todavía mayor si se tiene en consideración de la función de servicio público de cualquier medio público de comunicación. En especial, de 
su funcionamiento como medio de referencia y garante de la neutralidad y de la pluralidad política y social.

La opinión pública demanda una información de calidad en tiempo real. Una televisión pública no debe renunciar a informar con objetividad y profundidad. En las últimas convocatorias, la TVG ha entendido la importancia del momento de emitir los resultados electorales como un servicio público de alcance para la ciudadanía. Su apuesta por la proximidad es crucial para mantener la cercanía como uno de sus principales activos: la participación, el derecho de acceso, el diálogo político y la convicción de contribuir a la reflexión y adaptación social en una época de cambios profundos, además de la legítima aspiración a convertirse en un referente informativo de prestigio. Se trata, por tanto, de un evento especial para demostrar el potencial técnico y humano de la cadena. Experiencias anteriores permiten augurar un buen futuro en la cobertura de este tipo de eventos especiales, una oportunidad para los profesionales y un reto para la innovación en el marco de un servicio público esencial.

\section{Bibliografía}

Álvarez Rico, M. (ed.) (1999) Legislación básica de Informática. Madrid. Tecnos.

Arnaldo, E. y Delgado-Iribarren, M (2009) Código Electoral. Madrid. La Ley.

Blanco, R. (ed) (2011) Galicia. Estatutos de Autonomía, 1936 y 1981. Santiago. Parlamento de Galicia

Blumler, Jay G. (1994) 'Puede la televisión pública sobrevivir y prosperar en la Europa Occidental” en Zabaleta, I y Peñafiel, C. (ed.) El factor bumano en radio y televisión. Bilbao, UPV/EHU.

Campos, F. (2012) "Modelos de financiación de las televisiones autonómicas" en Miguel de Bustos, J.C. y Casado, M.A. (ed.) Televisiones autonómicas. Evolución y crisis del modelo público de proximidad. Barcelona. Gedisa.

Contreras, J.M. y Palacio, M. (2001) La programación en televisión. Madrid. Síntesis. 
Costa, P-O. (1986) La crisis de la televisión pública. Barcelona, Paidós Comunicación.

Galindo, Fermín (1998) Fundamentos de Comunicación Política. Tórculo, Santiago.

Merino Merchán, (ed.) (1996) Legislación electoral. Estatal, autonómica y de la Unión Europea. Madrid. Tecnos.

Moragas, M. y Garitaonandia, C. (2012) Prólogo en Miguel de Bustos, J.C. y Casado, M.A. (ed.) Televisiones autonómicas. Evolución y crisis del modelo público de proximidad. Barcelona. Gedisa.

Regueira, J.C. (2010) Producción de programas electorais en plató na TV G. Pontevedra, TFG. Univ. Vigo.

Vilas Nogueira, X. (1998) "Influencia de los medios audiovisuales en el rol del Parlamento" en Cotarelo, R. y Cuevas J.C. El cuarto poder. Medios de comunicación y legitimación democrática en España. Melilla, UNED.

\subsection{Otros documentos}

Acuerdos e instrucciones de la Junta Electoral Central.

Informes de producción elecciones TVG.

Informes sobre Xestión de Servicio Público de CRTVG.

O novo modelo organizativo dos servizos informativos da CRTVG. 



\title{
Transparencia y facilidad de acceso en los portales web de las televisiones públicas autonómicas
}

\author{
Ana María López-Cepeda \\ Belén Galletero Campos \\ Inmaculada Teruel Carrión \\ Universidad de Castilla-La Mancha
}

PARA CITAR: López-Cepeda, A.M., Galletero Campos, B. y Teruel Carrión, I. (2018). Transparencia y facilidad de acceso en los portales web de las televisiones públicas autonómicas. En Rodríguez-Castro, M., Pérez-Seijo, S. y CamposFreire, F. (Eds.). La TV Pública en Europa: Innovación, Retos y Tendencias (111-131). Cuadernos Artesanos de Comunicación, cac 146. La Laguna (Tenerife): Latina. DOI: $10.4185 /$ cac146.

\section{Resumen}

La viabilidad del modelo autonómico de las televisiones públicas en España está siendo cuestionada tras una serie de políticas audiovisuales que han puesto en duda su independencia, eficacia económica y credibilidad. En este contexto, una de las soluciones pasa por mejorar dos aspectos centrales en la gestión de bienes colectivos y recursos comunes: la transparencia y la facilidad de acceso.

Esta investigación tiene como finalidad conocer el nivel de transparencia y disponibilidad de información de las televisiones públicas autonómicas en España a través de sus portales corporativos. La metodología propone una medición a partir de indicadores extraídos de trabajos previos, de la legislación vigente y de 
investigaciones de referencia en el ámbito de la responsabilidad social y la rendición de cuentas. El objetivo es cuantificar el grado de cumplimiento que presentan las webs y el nivel de disponibilidad y facilidad de acceso a estos contenidos, así como los mecanismos con los que cuenta la ciudadanía para solicitar información pública de relevancia. A partir de los resultados numéricos, se puede obtener una comparativa entre los entes autonómicos para observar si se producen diferencias significativas entre ellos.

Palabras clave: transparencia, radiotelevisión, legislación, indicadores, corporaciones audiovisuales.

\section{Transparencia y rendición de cuentas}

El desarrollo de los sistemas políticos democráticos ha favorecido la expansión de los conceptos de rendición de cuentas y transparencia. Ambos son mecanismos procedentes de la ciencia política y económica que se han ido extendiendo a la idea de buen gobierno corporativo de las empresas e instituciones -tanto públicas como privadas-, incluidos los medios de comunicación (Puppis, 2010; López-Cepeda y ManfrediSánchez, 2018, pág. 414). La rendición de cuentas o accountability es entendida como la "supervisión permanente y constante de la gestión pública” (López-López, Puentes-Rivera y Rúas-Araújo, 2017), implicando - en palabras de Cameron (2004, pág: 59)- la posibilidad de una evaluación constante que prevenga el mal uso del poder (MorenoSardà, Molina-Rodríguez-Navas y Simelio-Soná, 2017, pág. 373). La transparencia se convierte en un mecanismo fundamental para la rendición de cuentas (O, Donnell, 2004) y en el caso de los medios de comunicación, constituye uno de sus tres pilares, junto a la autorregulación profesional y el fomento de la participación del público (Mauri Ríos y Ramón-Vegas, 2015). Según Pérez-Bravo (2004) la transparencia se define como la oferta de información y la adopción de mecanismos de participación y prácticas con el fin de mejorar la retroalimentación con la ciudadanía y reducir las posibilidades de corrupción (López-López, Puentes-Rivera y Rúas-Araújo, 2017; López-López, Vaca-Tapia, Molina Rodríguez-Navas, 2017, pág. 141). Se trata así de reconstruir la confianza en las instituciones a través de una nueva arquitectura de las relaciones (Manfredi-Sánchez, 2017, pág. 
356) entre todas las partes implicadas. En el caso de los medios de servicio público, estas serían los gobiernos y parlamentos, los mercados y la sociedad en su conjunto (Valencia-Bermúdez y Campos-Freire, 2016).

Para legitimar las dimensiones de la transparencia -constitucional, política, económica, y periodística- (Manfredi-Sánchez, 2017) se hace imprescindible que los ciudadanos reciban una información accesible para poder mejorar el servicio de que se trate (Kosack y Fung, 2014, p. 71) y que se proporcionen servicios más personalizados (Liikanen, 2003, p.13). El acceso a la información pública "es la más fundamental y clara concreción operativa de la transparencia" y "se encuadra dentro del llamado derecho a la información, cuyo objetivo es una mejor toma de decisiones por parte de la ciudadanía" (López-López, PuentesRivera y Rúas-Araújo, 2017). La accesibilidad supone que cualquier persona pueda conocer en cualquier lugar y en cualquier momento la información pública (Ramírez-Alujas, 2011, pág. 109). Esta se hace factible a través de las herramientas de internet. "Bajo el paradigma 2.0, las instituciones no solo proyectan un discurso y una imagen, que se pretende acorde a su identidad, sino también buscan recibir un feedback de sus actuaciones, escuchar para mejorar o proponer contenidos que interesen a los usuarios" (Costa-Sánchez, 2014; CostaSánchez y Túñez-López, 2017, pág. 126).

\section{La transparencia en los medios audiovisuales públicos}

La transparencia ha tenido en los medios de comunicación un buen aliado, ya que éstos han contribuido a la expansión del concepto, incorporándolo como un elemento de la gestión empresarial en las informaciones de las secciones de economía y sociedad (López-Cepeda y Manfredi-Sánchez, 2013, pág. 46). Pero los medios no deben olvidar que en sí mismos también son empresas e instituciones que deben ser transparentes y rendir cuentas ante su público, en el ejercicio de una correcta responsabilidad social (European Broadcasting Union, 2014). Estos conceptos se deben multiplicar en los medios de servicio público, entre los que se encuentran aquellos de proximidad, cuyas funciones y legitimidad han sido a veces cuestionadas por los actores políticos, bajo la justificación de priorizar otros servicios en un 
contexto de crisis económica y ajustes presupuestarios (Izquierdo Castillo y López Rabadán, 2016).

Las políticas europeas sobre transparencia y medios audiovisuales han tomado importancia en los últimos años. Una de las más destacables es la Directiva "Servicios de Medios Audiovisuales Sin Fronteras" (2007/65/CE) modificada en 2010 por la "Directiva de Servicios de Comunicación Audiovisual" (2010/13/UE). Esta norma señala la obligación de que los prestadores de servicios de comunicación audiovisual publiquen en sus webs una información de mínimos nombre del prestador del servicio de comunicación; dirección geográfica donde está establecido el prestador del servicio de comunicación; señas que permitan ponerse en contacto rápidamente con el prestador del servicio de comunicación y establecer una comunicación directa y efectiva con él, incluyendo su dirección de correo electrónico o sitio web; y en su caso, el órgano regulador o supervisor competente. La Recomendación CM/Rec (2012)1 sobre gobernanza de los medios de comunicación de servicio público, adoptada el 15 de febrero de 2012, profundiza la regulación de la transparencia en los medios de servicio público al señalar la importancia de que estos sean transparentes en información financiera, acuerdos de la junta, asuntos de otros órganos en la toma de decisiones y difusión del control de contenido (arts. 39-40) (López-Cepeda, 2017).

El modelo de referencia en Europa, BBC (Reino Unido), destaca por implantar importantes medidas de transparencia y rendición de cuentas (López-Cepeda y Manfredi-Sanchez, 2018). En otros Estados miembros, como Finlandia y Alemania, la justificación de la financiación y la mejora del servicio público han impulsado inciativas para una mayor transparencia (Ala-Fossi, 2012; Herzog, Novy, Hilker y Torun, 2018; Karppinen y Ala-Fossi, 2017). En España, hasta la entrada en vigor de la Ley 7/2010, de 31 de marzo, General de la Comunicación Audiovisual, existía un vacío legal sobre la regulación de la transparencia en medios de comunicación. Esta norma transpone la Directiva de Servicios de Comunicación Audiovisual señalando únicamente la obligación de los medios audiovisuales de publicar en su web los cuatro indicadores que señala la misma. Con anterioridad, en el ámbito estatal público la Ley 17/2006, de 5 de junio, de la radio y televisión de titularidad estatal preveía ya un sistema mixto de 
financiación -derogado en 2010- bajo criterios de proporcionalidad y transparencia europeos. Los requisitos de transparencia en la administración pública y, por extensión, en los medios de titularidad pública se han acentuado en nuestro país con la aprobación de la Ley 19/2013, de 9 de diciembre, de transparencia, acceso a la información pública y buen gobierno. Esta tiene un triple alcance:

1. Incrementar y reforzar la transparencia en la actividad pública-que se articula a través de obligaciones de publicidad activa para todas las Administraciones y entidades públicas-.

2. Reconocer y garantizar el acceso a la información -regulado como un derecho de amplio ámbito subjetivo y objetivo-.

3. Establecer las obligaciones de buen gobierno que deben cumplir los responsables públicos, así como las consecuencias jurídicas derivadas de su incumplimiento -lo que se convierte en una exigencia de responsabilidad para todos los que desarrollan actividades de relevancia pública-.

En el plano autonómico, algunas comunidades han desarrollado su propia normativa sobre transparencia, siendo la mayor parte de ellas posteriores a 2013, año de aprobación de la norma estatal. La pionera fue Galicia con la aprobación de la Ley 4/2006, de 30 de junio, de transparencia y de buenas prácticas en la Administración pública gallega. En orden cronológico, las autonomías que cuentan con legislación en la materia son Navarra (2012), Andalucía (2014), La Rioja (2014), Murcia (2014), Cataluña (2014), Castilla y León (2015), Comunidad Valencia (2015), Aragón (2015) y Canarias (2015). En las Islas Baleares está en vigor la Ley 4/2011, de 31 de marzo, de la buena administración y del buen gobierno, y en Extremadura la Ley 4/2013, de 21 de mayo, de Gobierno Abierto de Extremadura, si bien en el título no hacen referencia explícita a la transparencia. Las últimas en ser ratificadas han sido las de Castilla-La Mancha (2016) y Cantabria (2018), mientras que en Euskadi y Asturias su aprobación está en trámites. La comunidad de Madrid es la única en la que no hay una propuesta en curso, tras el rechazo de la oposición parlamentaria al proyecto de ley presentado en 2016. El análisis de las normas evidencia que la regulación es similar en prácticamente todas las regiones. Sin embargo, a pesar del incremento en las exigencias normativas, la 
ausencia de medidas sancionadoras bien determinadas ha podido restar eficacia, en especial en lo referente a la ley nacional (Guichot-Reina, 2014:104), quedando su mayor o menor accesibilidad a expensas del buen hacer de cada entidad.

En los últimos años algunas investigaciones se han encaminado hacia el desarrollo de instrumentos de medición que permitan llevar a lo concreto estos conceptos (López- Cepeda y Manfredi-Sánchez, 2013; Valencia-Bermúdez y Campos-Freire, 2016; López-López, PuentesRivera y Rúas-Araújo, 2017). Esta última aplica 29 indicadores a las televisiones estatales de España y Chile, y sus resultados revelan un nivel de cumplimiento de 62 sobre 100, por lo que, incluso en las corporaciones de ámbito nacional que suelen situarse algunos pasos por delante, cabe un mayor esfuerzo por dar a conocer los procedimientos de gestión y de gobernanza.

\section{Metodología}

El objetivo de esta investigación es analizar el nivel de transparencia de información de las corporaciones audiovisuales públicas autonómicas en España a través de sus portales corporativos. Los trece entes estudiados son de titularidad pública y todos pertenecen a la Federación de Organismos de Radio y Televisión Autonómicos (FORTA) excepto la Corporación Extremeña de Medios Audiovisuales. Los indicadores propuestos han sido extraídos de la legislación vigente y completados con investigaciones de referencia en el ámbito objeto de estudio (en especial, López-Cepeda y ManfrediSánchez, 2013; Valencia-Bermúdez y Campos-Freire, 2016; LópezLópez, Puentes-Rivera y Rúas-Araújo, 2017). La metodología se basa en la aplicada en anteriores trabajos realizados sobre los portales institucionales de ayuntamientos en el marco del proyecto de investigación GlobalCom (CSO2013-46997-R) que surge con la finalidad de atender a la evolución en el grado de transparencia en la comunicación pública digital local.

El análisis se realiza tres años después de la entrada en vigor en el ámbito autonómico de la Ley 19/2013, de 9 de diciembre, de transparencia, acceso a la información pública y buen gobierno, entendiendo que ha transcurrido suficiente tiempo para que las empresas audiovisuales públicas hayan adoptado sus obligaciones y 
recomendaciones. Ya en el año 2013 se realizó una primera aproximación a la transparencia en televisiones públicas y privadas españolas de acuerdo a los requerimientos de la Ley 7/2010, de 31 de marzo, General de la Comunicación Audiovisual (López-Cepeda y Manfredi-Sánchez, 2013), con un nivel de exigencia mucho menor que la actual legislación. Tres años después, en 2016, la investigación se amplió con un trabajo exploratorio en el momento de la entrada en vigor de la Ley de Transparencia en el ámbito autonómico. Este primer análisis, que culminó en el Trabajo de Fin de Grado de una de las autoras del presente artículo (Teruel, 2016), es un punto de partida que permitirá conocer la evolución de la transparencia en los últimos tres años. De esta manera, esta investigación presenta una propuesta actualizada, acorde con los últimos cambios legislativos, además de ofrecer una panorámica completa al configurar la muestra con la totalidad de las corporaciones públicas de ámbito autonómico. En la primera oleada (2015-2016) se analizaron un total de 51 indicadores, ampliados hasta 82 en esta segunda (2018). Los ítems analizados se han dividido en cuatro ejes temáticos, de acuerdo a los artículos 6,7 y 8 de la Ley 19/2013 a los que se ha añadido un apartado relativo a la información de tipo corporativo y a los recursos para el fomento de la participación.

\section{Información institucional, organizativa y de planificación:} Información relativa a las funciones que desarrollan los órganos de gobernanza (competencias y/o calendario); Información básica de los órganos de gobernanza (nombre, apellidos y foto); Organigrama (biografía, datos de contacto de los órganos de gobernanza y estructura organizativa); Planes, programas anuales y/o plurianuales y objetivos y el tiempo previsto para su consecución; Sección de transparencia propia.

2. Información de relevancia jurídica: convocatoria y actas de las reuniones de los órganos de gobernanza; Normas; Autorregulación; Convenio colectivo.

\section{Información económica, presupuestaria y estadística:}

Presupuestos (presupuestos, informes de ejecución y modificaciones); Cuentas anuales (cuentas anuales e informes de auditorías); Información diferenciada de gastos e ingresos; Retribuciones de los órganos de gobernanza; Declaración de 
intereses personales de los órganos de gobernanza; Contratos (relación de contratos formalizados y mención de las partes firmantes, perfil del contratante propio o en la web de la Junta pero con carácter diferenciado. Para este caso se analizará si se publican en él licitaciones, en curso, pliegos de condiciones, adjudicaciones, mesas de contratación, actas de las mismas y renuncias o desistimiento de los contratos); Memorias sobre el cumplimiento de servicio público (preferentemente con información estadística); Bienes inmuebles; Subvenciones y ayudas públicas.

4. Gestión de recursos y participación: Noticias (noticias sobre lo que acuerdan en las reuniones, plenos o juntas de los órganos de gobernanza, noticias corporativas); Responsable de comunicación; Historia; Mecanismos de quejas y/o sugerencias; Acceso a redes sociales (Facebook, Twitter, otras redes); Contacto de medio.

El rango de cumplimiento de los indicadores se ha traducido en una medida porcentual de tal modo que permita realizar una comparativa entre las corporaciones en estas cuatro dimensiones y establecer una escala de mayor a menor transparencia. El análisis se completa con una variable denominada "número de clicks" que nos permitirá conocer la facilidad de acceso a la información publicada en las webs por las radiotelevisiones públicas autonómicas. Se parte del número de clicks realizados desde la web corporativa, en el caso de que esta exista, y hasta poder visualizar la información estudiada.

\section{Resultados}

\begin{tabular}{|l|c|c|c|c|c|}
\hline $\begin{array}{c}\text { Radio } \\
\text { Televisión } \\
\text { pública }\end{array}$ & $\begin{array}{c}\text { Información } \\
\text { institucional, } \\
\text { organizativa y } \\
\text { de planifica- } \\
\text { ción }\end{array}$ & $\begin{array}{c}\text { Información } \\
\text { de relevancia } \\
\text { jurídica }\end{array}$ & $\begin{array}{c}\text { Información } \\
\text { económica, } \\
\text { presupuestaria y } \\
\text { estadística }\end{array}$ & $\begin{array}{c}\text { Gestión de } \\
\text { recursos y } \\
\text { participa- } \\
\text { ción }\end{array}$ & $\begin{array}{c}\text { Total } \\
\text { (sobre 82 } \\
\text { indicado- } \\
\text { res) }\end{array}$ \\
\hline $\begin{array}{l}\text { RTVA } \\
\text { (Andalucía) }\end{array}$ & $45,8 \%$ & $15,4 \%$ & $42,9 \%$ & $52,9 \%$ & $47,6 \%$ \\
\hline $\begin{array}{l}\text { CARTV } \\
\text { (Aragón) }\end{array}$ & $29,2 \%$ & $46,1 \%$ & $35,7 \%$ & $52,9 \%$ & $32 \%$ \\
\hline $\begin{array}{l}\text { RTPA } \\
\text { (Asturias) }\end{array}$ & $29,1 \%$ & $23 \%$ & $46,4 \%$ & $35,3 \%$ & $29 \%$ \\
\hline
\end{tabular}




\begin{tabular}{|l|c|c|c|c|c|}
\hline $\begin{array}{l}\text { EPRTVIB } \\
\text { Baleares }\end{array}$ & $25 \%$ & $23 \%$ & $28,6 \%$ & $52,9 \%$ & $26 \%$ \\
\hline $\begin{array}{l}\text { RTVC } \\
\text { Canarias) }\end{array}$ & $16,7 \%$ & $15,4 \%$ & $32,1 \%$ & $52,9 \%$ & $24 \%$ \\
\hline $\begin{array}{l}\text { CMM (Castilla- } \\
\text { La Mancha) }\end{array}$ & $29,1 \%$ & $38,4 \%$ & $32,1 \%$ & $52,9 \%$ & $30 \%$ \\
\hline $\begin{array}{l}\text { CCMA } \\
\text { (Cataluña) }\end{array}$ & $50 \%$ & $30,8 \%$ & $35,7 \%$ & $52,9 \%$ & $41,5 \%$ \\
\hline $\begin{array}{l}\text { RTVM (C. de } \\
\text { Madrid) }\end{array}$ & $25 \%$ & $15,4 \%$ & $25 \%$ & $52,9 \%$ & $29,3 \%$ \\
\hline $\begin{array}{l}\text { CVMC (C. } \\
\text { Valenciana) }\end{array}$ & $16,7 \%$ & $15,4 \%$ & $21,4 \%$ & $17,6 \%$ & $18,3 \%$ \\
\hline $\begin{array}{l}\text { CEXMA } \\
\text { (Extremadura) }\end{array}$ & $4,17 \%$ & $23,1 \%$ & $32,1 \%$ & $35,3 \%$ & $23,2 \%$ \\
\hline $\begin{array}{l}\text { CRTVG } \\
\text { (Galicia) }\end{array}$ & $29,2 \%$ & $53,8 \%$ & $46,4 \%$ & $58,8 \%$ & $45,1 \%$ \\
\hline $\begin{array}{l}\text { RTRM (Murcia) } \\
\text { EITB }\end{array}$ & $20,8 \%$ & $15,4 \%$ & $50 \%$ & $29 \%, 4 \%$ & $39 \%$ \\
\hline
\end{tabular}

Tabla 1. Fuente: Elaboración propia, 2018.

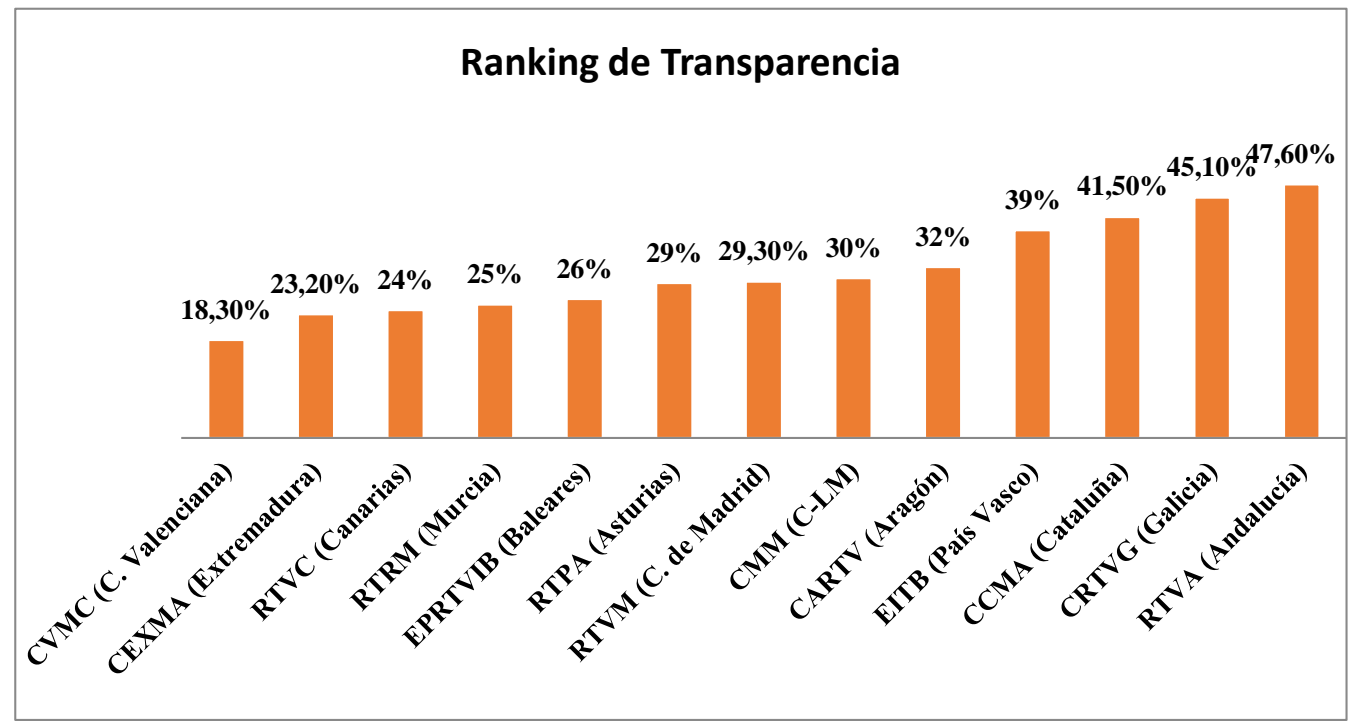

Ilustración 1. Fuente: Elaboración propia, 2018.

A la vista del cumplimiento de los indicadores, las corporaciones que presentan mayores niveles de transparencia son las de Andalucía, Cataluña, Galicia y el País Vasco. En este aspecto no se han registrado cambios desde 2015 ya que estas mismas ocupaban las primeras posiciones. Las más completas son la del Grupo EITB y la de la 
Corporación Radio e Televisión de Galicia, con un cumplimiento cercano o superior al 50\% de los indicadores en al menos tres de los cuatro apartados. En el extremo opuesto encontramos las webs de la corporación extremeña y la canaria. Esta última ofrece información sobre aspectos económicos - presupuestos, cuentas anuales diferenciadas para radio y TV, auditoría, relación de contratos, retribuciones de director y plantilla, y bienes de su propiedad - pero apenas sobre cuestiones orgánicas de funcionamiento: no aparecen identificadas las funciones de los órganos de gestión ni se explican los procedimientos de elección. Tampoco se puede conocer si existen códigos de autorregulación ni se localizan normas de calidad. En cuanto a la extremeña, las deficiencias que ya presentaba en 2015 - sólo publicaba datos de contacto, vía de sugerencias/reclamaciones, ley de creación del ente, adjudicaciones y actas de las mesas de contratación persisten en la actualidad- si bien mejora en información económica, presupuestaria y estadística. Los mayores cambios se aprecian en la web de Castilla-La Mancha Media - en 2016 adopta una nueva identidad y lanza un nuevo portal, más intuitivo y accesible - y en el portal de la Corporació Valenciana de Mitjans de Comunicació, creada en julio 2016 y por ello, con pocos datos todavía.

No se percibe una relación directa entre las corporaciones más transparentes y el desarrollo de legislación autonómica en materia de transparencia. En el caso de Galicia, sí podría imputarse la mejor puntuación a una cultura de rendición de cuentas más asentada, apoyada en una ley autonómica que tiene más de una década; en cambio, la sección de Transparencia del Grupo EITB abarca muchos más aspectos que la media, a pesar de que no se haya aprobado aún la normativa específica en el Parlamento vasco. Sí se aprecia, sin embargo, una relación entre la transparencia y los medios de titularidad pública más antiguos. Son precisamente las corporaciones de Andalucía, Cataluña, País Vasco y Galicia las que cumplen un mayor número de indicadores, siendo estas las primeras en desarrollarse históricamente junto con la madrileña y valenciana, si bien esta de reciente creación tras su cierre en 2013. RTVM es la única de las tradicionales que no se encuentra en las posiciones más altas, ocupando un séptimo lugar en el ranking de transparencia. 


\subsection{Información institucional, organizativa y de planificación}

A la luz de los datos, en este apartado se presta atención a la figura que ostenta la dirección de los entes o corporaciones como máximo responsable, identificando su identidad, trayectoria, funciones e incluso agenda del/la directora/a general. Sin embargo, no sucede lo mismo con el resto de órganos gestores. En términos generales, aunque sus competencias aparecen relatadas de manera clara, son mejorables en todos los casos los datos de contacto y trayectoria profesional del Consejo de Administración y del Consejo Asesor. Las corporaciones deberían hacer público, al menos, el nombre completo de cada miembro, una fotografía, un mail de contacto, el currículo y la declaración de intereses personales siguiendo el modelo de la BBC en Reino Unido. Este último dato de los miembros de los órganos de gobernanza no figura en ninguno de los portales. La agenda del máximo responsable se publica sólo en la web de Castilla-La Mancha Media y de la Corporació Catalana de Mitjans Audiovisuals.

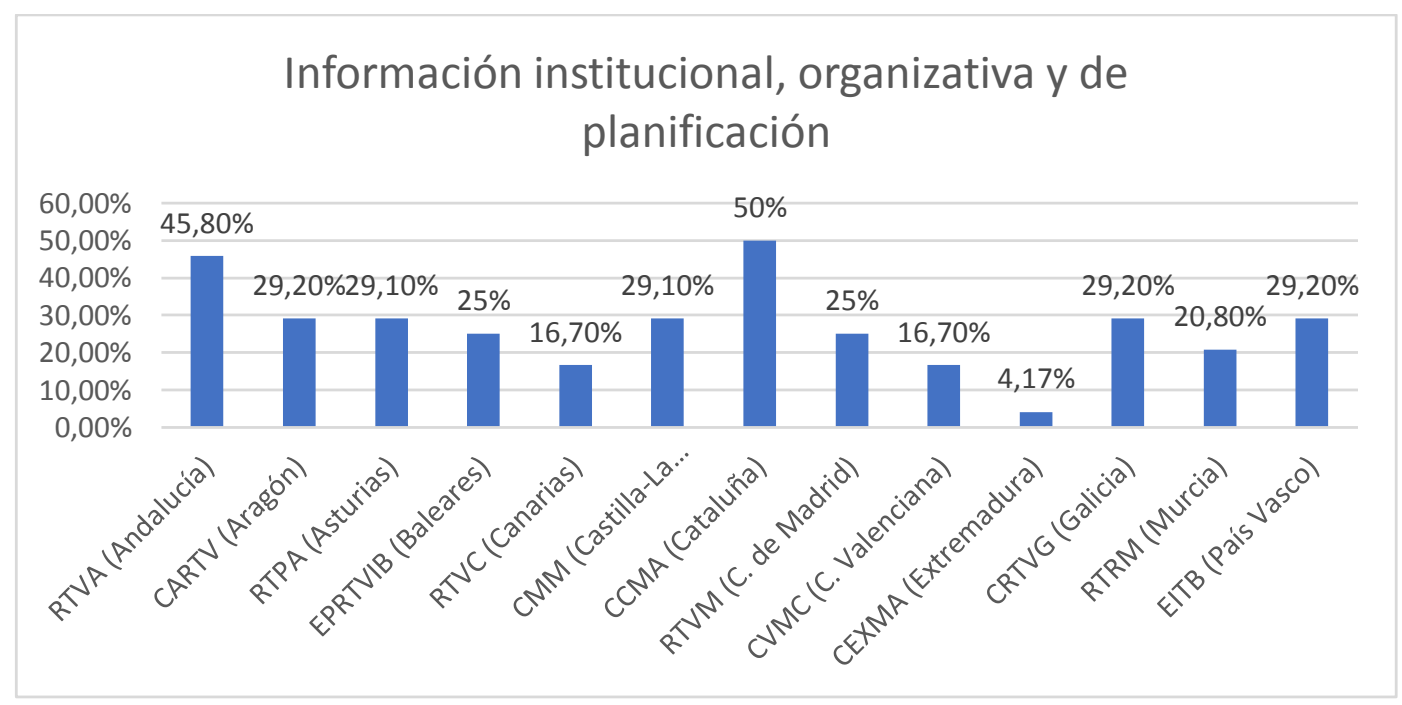

Ilustración 2. Fuente: Elaboración propia, 2018.

La comparativa con los resultados de 2015/2016 evidencia una cierta mejora, pero escasa. La CCMA (Cataluña) y CMM (Castilla-La Mancha) publican ahora las competencias de Director, Consejo de Administración y Consejo Asesor e incluso el calendario de reuniones del primero de ellos. Se mejora en la publicación de la biografía y currículo del consejo de administración de RTVM (Comunidad de Madrid), pero no hay cambios importantes en el resto de las 
radiotelevisiones analizadas. Según la ley, "las Administraciones Públicas publicarán los planes y programas anuales y plurianuales en los que se fijen objetivos concretos, así como las actividades, medios y tiempo previsto para su consecución". Sin embargo, hay todavía cuatro radiotelevisiones públicas (la de Castilla-La Mancha, Canarias, Madrid y Extremadura) que no han desarrollado o no publican su mandato marco ni contrato programa.

\subsection{Información de relevancia jurídica}

En la información relacionada con el funcionamiento orgánico de las compañías es donde se registra un mayor déficit de transparencia. En este aspecto, ocho de las trece corporaciones no alcanzan ni un tercio de los indicadores exigibles. El 38\% de los portales se sitúan en un nivel de cumplimiento del 15\%. El único dato que aparece en todas las webs es la ley de creación del ente. Sin embargo, no se publican ni las convocatorias ni las actas de reuniones de los órganos de gobernanza ni en la primera ni en la segunda oleada de mediciones en doce de las trece webs analizadas. La única entidad que difunde esa información es la de Murcia.

De la Corporación Aragonesa de Radiotelevisión se puede destacar la incorporación de memorias anuales de actividad en formato de documento dinámico. En ellas se ofrece un resumen de los resultados de los diferentes departamentos, las reuniones del Consejo de Administración, actos corporativos, audiencias, entre otros datos. Este tipo de documento, ya utilizado hace algunos años por algunas corporaciones europeas (Fernández Lombao, 2013), constituye un buen ejemplo de rendición de cuentas; sin embargo, un paso más en la exigencia es someterse a auditorías externas o sistemas de calidad. Sólo tres corporaciones (CMM, EITB y CRTVG) proporcionan certificaciones externas que evalúan la responsabilidad social corporativa. 


\section{Información de relevancia jurídica}

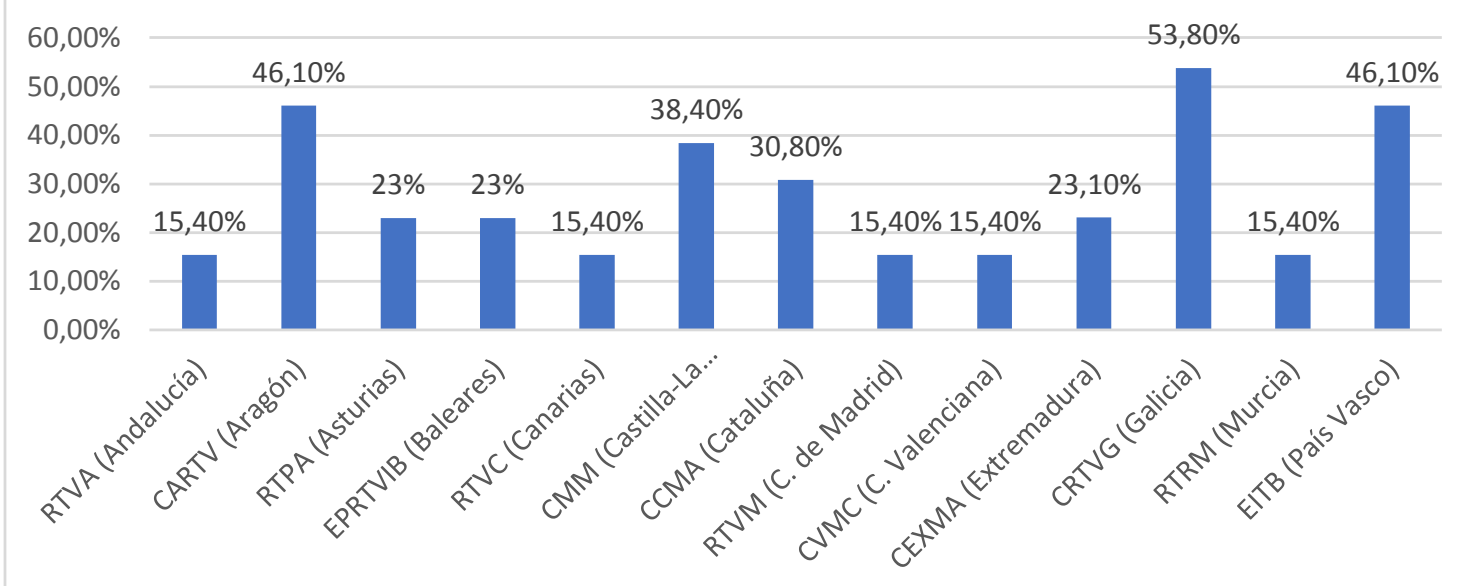

Ilustración 3. Fuente: Elaboración propia, 2018

Como ya habían destacado López-Cepeda y Manfredi-Sánchez (2013), la transparencia debe aplicarse también en la especificidad de la actividad informativa, por la naturaleza del material sobre el que trabajan, la información, y por su influencia en la esfera pública. Para ello es preciso desarrollar instrumentos propios, entre los que destacan los códigos de autorregulación. La incorporación de normas deontológicas pone de manifiesto la creciente preocupación por preservar el buen hacer profesional y por proteger a los colectivos más vulnerables. Todas las webs de las corporaciones excepto la murciana y madrileña difunden algún tipo de código ético, ya sea el libro de estilo (RTVA, CCMA IB3, EITB, CVMC y CRTVG), de protección de la infancia o colectivos vulnerables (RTVA, CCMA, CMM, CARTV, IB3, RTPA, CVMC, CRTVG y CEXMA) o de conducta publicitaria (RTVA, CMM, CARTV, RTVC y CRTVG), si bien la más ambiciosa en este aspecto es la vasca - cumple todos los indicadores de autorregulación e incluso ha incorporado un decálogo para el uso de las redes sociales y un manual de buenas prácticas para gestionar programas en redes sociales. También lo hacen la gallega y la catalana.

Dentro de la transparencia de carácter interno caben también las políticas laborales ya que ayudan a relacionar las condiciones de trabajo con el resultado periodístico (López-Cepeda y Manfredi-Sánchez, 2018). Las radiotelevisiones públicas de Baleares, Murcia, Canarias y Madrid no hacen público el convenio colectivo, privando a la audiencia de conocer en qué circunstancias desarrollan los trabajadores sus funciones. Hay que añadir que, en este ítem, apenas se han producido 
cambios desde la primera medición. CMVC en Valencia tampoco lo publica, lo cual es comprensible debido a reciente puesta en marcha en la actualidad.

\subsection{Información económica, presupuestaria y estadística}

En cuanto a la información económica, presupuestaria y estadística, a pesar de ser indicadores fundamentales por tratar presupuestos públicos, no hay muchas mejoras evidentes. Sí se percibe algún cambio positivo en la Comunidad de Madrid, en esencia en la publicación de datos relacionados con el perfil del contratante, y en Galicia (CRTVG) en relación a los presupuestos y cuentas anuales. La web de CEXMA (Extremadura) es la que en mayor medida presenta mejoras en este apartado tanto relacionadas con presupuestos y cuentas anuales como con los contratos y perfil del contratante. EITB también ha incrementado su nivel de transparencia con la publicación de los contratos formalizados. Por su parte, CMM publica ahora cuentas anuales e informes de auditoría, además de la información salarial de la plantilla. La web de la corporación murciana, si bien presenta carencias en otros apartados, destaca por la amplia información sobre los procedimientos de licitación y adjudicación, al igual que la relativa a la gestión económica y presupuestaria. Sólo cinco publican la relación de bienes inmuebles de su propiedad y en el caso de EITB también incluye un apartado de 'Declaraciones de bienes y actividades de los cargos públicos' dentro de la sección dedicada a la Transparencia, aunque el enlace remite a la web del gobierno vasco.

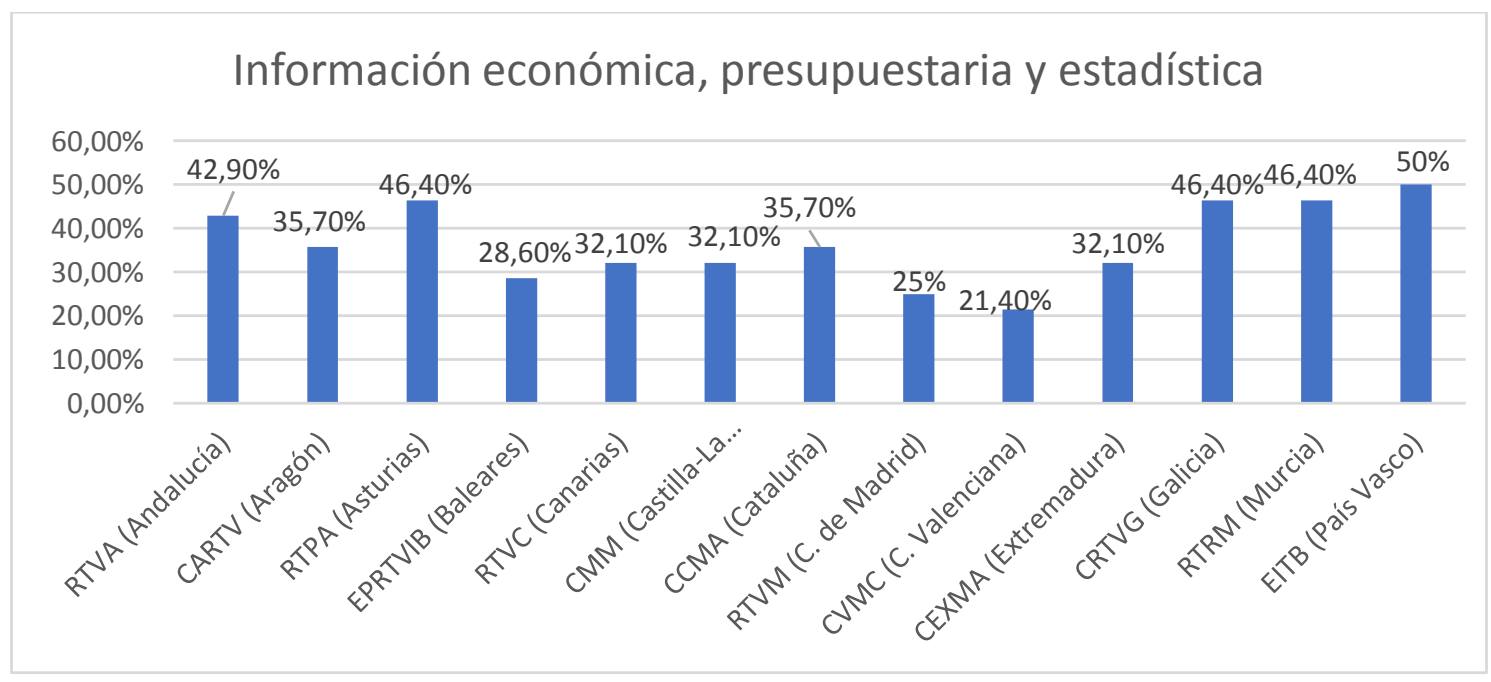

Ilustración 4. Fuente: Elaboración propia, 2018 
Solo tres (RTVA, CCMA y RTVG) presentan un informe de resultados sobre el grado de cumplimiento y calidad de los servicios públicos a pesar de que la ley exige de manera explícita en su artículo 8 que "las entidades públicas deben proporcionar la información estadística necesaria" para valorar estos aspectos.

La mayoría de las webs difunden las retribuciones del director y de la plantilla (8.1) pero solo CCMA y CRTVG publican las del Consejo de Administración y en ninguno de los casos estudiados las del Consejo Asesor u otros órganos. Las dietas que perciben deberían ser también accesibles.

\subsection{Gestión de recursos y participación}

Es el apartado que presenta mejores datos de cumplimiento ya que muchos de los indicadores tienen que ver con la facilidad de acceso a los contenidos y a la información corporativa. Se aprecia una voluntad clara por fomentar el diálogo con los grupos de interés. Así, los datos relativos a la participación y aquellos destinados a mejorar el acceso y la participación de la ciudadanía ofrecen buenos resultados tanto en el análisis de 2015/2016 como en el del 2018 pero sin mejoras comprobables a lo largo de los tres años.

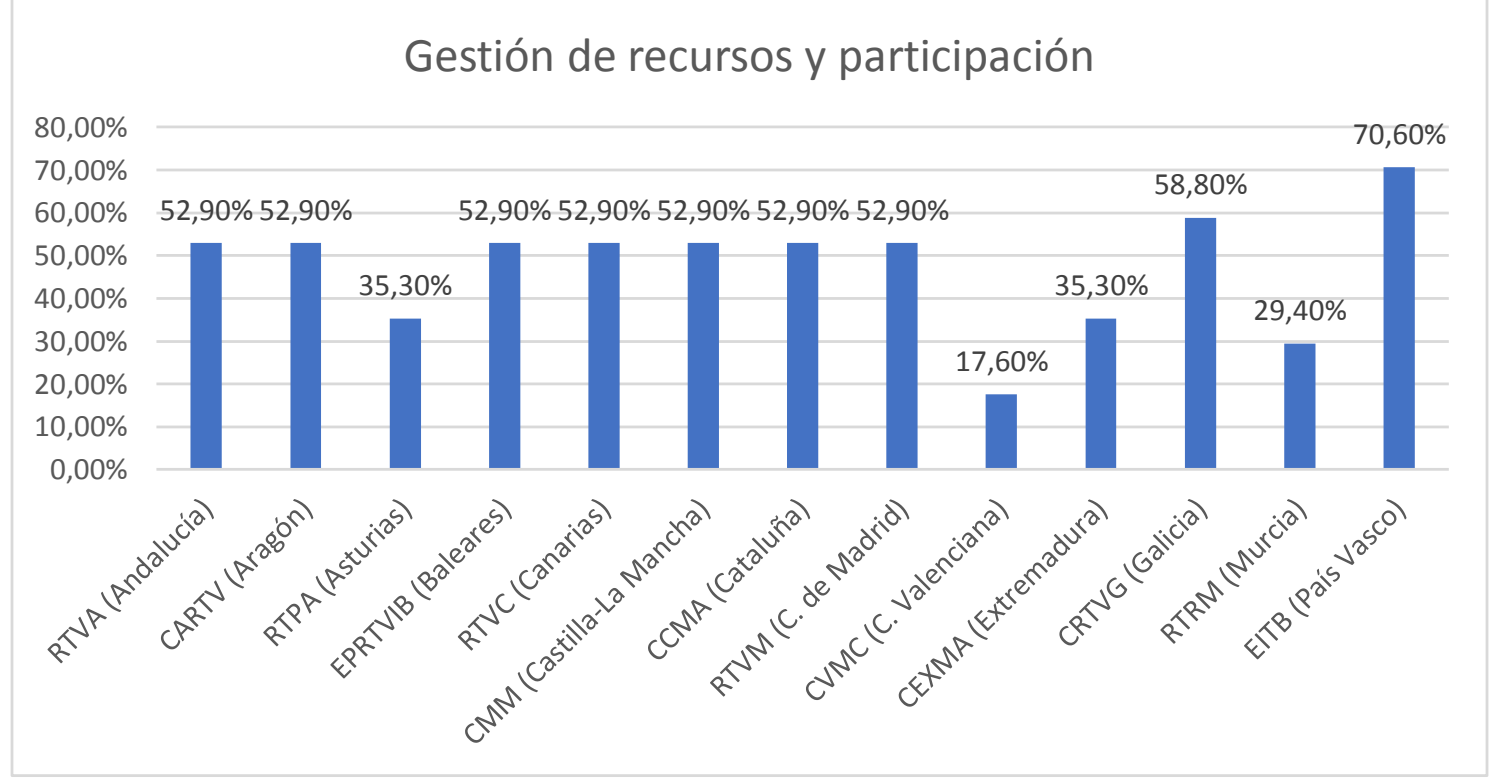

Ilustración 5. Fuente: Elaboración propia

De nuevo, existen lagunas en la información relativa a las reuniones, plenos o juntas de los órganos de gestión y control. La corporación de 
Murcia y la de Asturias difunden escasa información de contacto en el portal corporativo (ni perfiles de redes sociales ni modo de contacto con responsable de prensa), en comparación con el resto de entidades.

Los mecanismos de quejas o sugerencias están presentes en nueve de las trece webs corporativas. Otro dato relevante es que ni CMM, ni RTPA, ni RTRM, ni CVMC, ni CEXMA, ni RTVA publican una reseña de la evolución histórica del ente. Como organismos de interlocución con el público destaca la Oficina del Espectador en la Radiotelevisión Canaria y la Defensoría de EITB.

\subsection{Facilidad de acceso}

A pesar del bajo nivel de transparencia detectado a partir de los indicadores, hay que destacar como aspecto positivo que todas han incorporado una sección específica de transparencia, cuestión que facilita el acceso a los datos.

La facilidad de acceso que ofrecen las webs de las radiotelevisiones públicas es en general positiva. La dificultad se produce en el momento en el que no disponen de un perfil de contratante propio diferenciado de aquel correspondiente al gobierno regional. Encontramos este supuesto de dificultad en el caso de Cataluña (que igualmente remite en los presupuestos a la web de la junta autonómica) y Canarias. En IB3 de Baleares y Castilla-La Mancha Media el enlace remite a la Plataforma de Contratación del Ministerio de Hacienda. Sí incorporan un perfil propio las webs de EITB, de RTV Región de Murcia y la corporación de Asturias. La Corporación Aragonesa de Radiotelevisión, Radio Televisión de Andalucía, Radio Televisión Madrid y la Corporación Radio e Televisión de Galicia tienen un apartado de perfil de contratante que remite a la aplicación gubernamental de la Administración autonómica, pero en ella hay un apartado específico para los concursos de cada corporación.

El número de clicks varía de entre 1 a 5 en CCMA y CEXMA. En CMM, al no haber un portal corporativo diferenciado, el número medio de clicks es 3 y el acceso a los contenidos puede resultar menos intuitivo que en otros portales. En RTRM y en RTPA el número medio oscila entre 2 y 3 . En el caso de Asturias, hay que señalar que figuran 
epígrafes a la estructura de la plantilla, al contrato programa y al mandato marco, pero los enlaces no funcionan.

Las webs más claras son las de CRTVG, con una información muy clara muy fácil de encontrar, y CMVC (Valencia). En esta última web la información es accesible teniendo en cuenta que, debido a que la corporación está en sus inicios tras su cierre, la información disponible no es muy abundante. La web de la corporación aragonesa, a pesar de ser bastante completa en información disponible, se despliega en varios menús pero no permite ver los epígrafes de cada uno de ellos, lo que incrementa hasta 5 el número de clicks hasta visualizar la información deseada. Un ejemplo son los datos relativos a los presupuestos y cuentas anuales. En la web de la corporación canaria el número de clicks se sitúa entre 4 y 5, por lo que no sólo caben mejoras en cuanto a la información disponible sino también en su organización y distribución en el portal.

Otro aspecto mejorable es la traducción de los datos (por ejemplo, la estructura de la plantilla) en informaciones gráficas que permitan su mejor interpretación. Sólo CMM y EITB presentan la información de este modo, aunque en esta última está desactualizada, con datos correspondientes a 2014.

\section{Conclusiones}

El camino hacia una concepción empresarial abierta y transparente ha dejado atrás los procedimientos de gestión considerados únicamente a nivel interno. El desarrollo de políticas en favor de una mayor transparencia parece ya estar asimilado y forma parte de la cultura corporativa de la empresa pública de una manera cada vez más clara y accesible. Sin embargo, queda demostrado que el nivel de exigencia que persigue la legislación no se corresponde con su aplicación práctica en el caso de las corporaciones audiovisuales, que han asumido parte de los requerimientos, pero no todos. A pesar de que formalmente todas han desarrollado un apartado específico dedicado a la transparencia, ninguna ofrece más de la mitad de los indicadores extraídos de la legislación y de investigaciones de referencia. Para que la transparencia no sea sólo una cuestión tangencial en pro de mejorar la imagen 
corporativa debe integrarse en la filosofía empresarial y guiar las acciones internas y externas.

La interpretación de las normativas parece poner el foco en las figuras superiores de gestión - el/la directora/a general - pero descuida aquella información relativa a otros órganos igualmente importantes en la gestión de estas entidades, como son el Consejo de Administración, el Consejo Asesor o el Consejo de Informativos. Apenas se publican datos sobre las reuniones que mantienen, las responsabilidades ejercidas, la trayectoria de sus componentes y sus datos de contacto, de tal manera que no se puede valorar su adecuación al puesto o el nivel de trabajo desarrollado para el ente. Tampoco es muy habitual publicar las retribuciones de estos órganos de gobernanza y en ningún caso se difunde la declaración de intereses personales de sus miembros.

Otra carencia percibida se encuentra, en algunos de los casos estudiados, en que se omiten normas tan importantes como el convenio colectivo, el contrato programa o el mandato marco.

En lo relativo a la información económica y presupuestaria el principal déficit es la falta de accesibilidad a través -en muchas ocasiones- de enlaces al perfil del contratante de los gobiernos autonómicos y no a perfiles propios, diferenciados o autónomos.

La gestión de recursos y participación no es negativa, pero de nuevo hay serios déficits en las noticias sobre decisiones y reuniones de los principales órganos de gobernanza. Los medios de comunicación públicos, conocedores de la importancia de relacionarse con las audiencias, publican noticias corporativas, disponen de redes sociales y de otras formas de comunicación con las mismas, pero muchas veces olvidan difundir información tan vital como la historia, información sobre lo que se acuerda en las reuniones, juntas o plenos, o el contacto del responsable de prensa.

Las mejoras que se han producido en los últimos tres años son poco relevantes, excepto en los casos en los que las corporaciones han experimentado cambios, como es el caso de la antigua Radiotelevisión Castilla-La Mancha, ahora Castilla-la Mancha Media, o la nueva corporación valenciana. 


\section{Referencias biliográficas}

Ala-Fossi, M. (2012). "Social Obsolescence of the TV Fee and the Financial Crisis of Finnish Public Service Media", Journal of Media Business Studies, v. 9 n. 1, pp. 33-54.

Cameron, W. (2004). "Public accountability: Effectiveness, equity, ethics". Australian journal of public administration, v. 63, n. 4, pp. 56-67

Costa-Sánchez, C. (2014). "El cambio que viene. Audiovisual branded content”. Telos, 99, pp. 84-94

Costa-Sánchez, C. y Túñez-López, M. (2017). “Información corporativa en línea de las televisiones públicas europeas y sus relaciones con la audiencia", Comunicación y Medios, n. 36, pp. 125-139

Fernández-Lombao, T. (2013). "Las corporaciones de radiotelevisión pública de la Unión Europea y el incipiente uso de la Web 2.0 para comunicar RSC", Fonseca, Journal of Communication, n. 6, pp. 84-107.

Guichot-Reina, E. (2014). "La nueva ley de transparencia, un reto para la gestión de las organizaciones públicas". Revista Vasca de Gestión de Personas y Organizaciones Públicas, n. 6, pp. 94-107.

Herzog C., Novy L., Hilker H. y Torun O. (2017). "Transparency and Funding of Public Service Media in Germany, the Western World and Beyond". En Herzog Hilker, Novy y Torun (eds) Transparency and Funding of Public Service Media - Die deutsche Debatte im internationalen Kontext. Wiesbade: Springer VS, pp. 317.

Izquierdo Castillo, J. y López Rabadán, P. (2016). "Nuevos retos y dificultades para los medios de comunicación públicos de proximidad". adComunica. Revista Científica de Estrategias, Tendencias e Innovación en Comunicación, nº11. Castellón: Asociación para el Desarrollo de la Comunicación. adComunica y Universitat Jaume I, pp. 19-21. DOI: http://dx.doi.org/10.6035/2174-0992.2016.11.2

Karppinen K. y Ala-Fossi M. (2017). "Finland: Maintaining the Fragile Consensus". En Herzog Hilker, Novy y Torun (eds.) Transparency and Funding of Public Service Media - Die deutsche 
Debatte im internationalen Kontext. Wiesbaden: Springer VS, pp. 107-117.

Kosack, S. y Fung, A. (2014). "Does Transparency Improve Governance?”. Annual Review of Political Science, v. 67, pp. 6587.

Liikanen, E. (2003). “Administración Electrónica y la Unión Europea”, Novática, n. 162, pp. 13-16.

López-Cepeda, AM. (2017). "La gobernanza en la radiotelevisión pública europea. El modelo español”. En Túñez, Campos y Silva (eds.). Estudios sobre legislación, financiación e innovación en la televisión pública. Tenerife: Cuadernos Artesanos de Comunicación, pp. 41-58.

López-Cepeda, A.M. y Manfredi-Sánchez, J.L. (2013). “Análisis de la transparencia de las páginas web de los principales medios de comunicación audiovisuales en España”, Trípodos, n. 32, pág. 45-61.

López-Cepeda, A.M y Manfredi-Sánchez, J.L. (2018). “Transparencia y medios de comunicación de servicio público”. En López, Campos, López y Rivas (eds.). La comunicación en la nueva sociedad digital. Ecuador: Centro de Comunicaciones, pp. 413433.

López-López, P.C., Puentes-Rivera, I. y Rúas-Araújo, J. (2017). Transparencia en televisiones públicas: desarrollo de indicadores y análisis de los casos de España y Chile, Revista Latina de Comunicación Social, 72, pp. 253-272. Recuperado en http://www.revistalatinacs.org/072paper/1164/14es.html López-López, P.C., Vaca-Tapia, A.C. y Molina Rodríguez-Navas, P.M. (2017). "La transparencia en las televisiones del Ecuador: una revisión legal de la información pública", ComHumanitas Revista Cientifica de Comunicación, vol. 10, n. 1, pp. 137-158.

Manfredi-Sánchez, J.L. (2017). "Horizontes de la información pública". El profesional de la información, v. 26, n. 3, pp. 353-360. Mauri-Ríos, Marcel; Ramon-Vegas, Xavier (2015). "Nuevos sistemas de rendición de cuentas de la información periodística. Exploración del escenario online español". El profesional de la información, v. 24, n. 4, pp. 380-389. 
http:/ /www.elprofesionaldelainformacion.com/contenidos/ 2015/jul/04.pdf

Moreno-Sardà, Molina-Rodríguez-Navas y Simelio-Soná (2017).

"Impacto de la legislación sobre la transparencia en la información publicada por las Administraciones locales", El profesional de la información, v. 26, n.3, pp. 370-380.

O’Donnell, G. (2004). Accountability horizontal: la institucionalización legal de la desconfianza política, Revista Española de Ciencia Política, 11, pp. 11-31.

Pérez Bravo, M.J (2004). "Discusión parlamentaria en los temas de transparencia en el marco de las reformas del Estado: Análisis del acuerdo parlamentario 2003". Tesis de Maestría.

Universidad de Chile: Santiago de Chile.

Puppis, M. (2010). "Media Governance: A New Concept for the Analysis of Media Policy and Regulation. Communication", Culture \& Critique, v.3, n. 2, pp. 134-149.

Ramírez-Alujas, A.V. (2011). "Gobierno abierto y modernización de la gestión pública: Tendencias actuales y el (inevitable) que viene. Reflexiones seminales", Revista Enfoques, v. 9, n. 15, pp. 99-125.

Teruel, I (2016). "Transparencia y participación en las webs de la radiotelevisión pública en España". Trabajo Fin de Grado.

Facultad de Periodismo. Universidad de Castilla-La Mancha Valencia-Bermúdez, A. y Campos-Freire, F. (2016). "Value indicators for regional broadcasters: accountability in EITB, CCMA and CRTVG". Communication and Society, n. 29, pp. 59-68.

\subsection{Otros documentos}

European Broadcasting Union (2014). PSM Values Review.The Tool. Recuperado de https://www.ebu.ch/contents/publications/psm-valuesreview-the-tool.html 



\title{
El uso estratégico del audiovisual en el manejo de la información local-global. Caso de estudio la disidencia en la frontera colombo-ecuatoriana
}

\author{
Kruzkaya Ordóñez González \\ Catalina Mier-Sanmartín \\ Universidad Técnica Particular de Loja
}

\begin{abstract}
PARA CITAR: Ordóñez, K. y Mier-Sanmartín, C. (2018). El uso estratégico del audiovisual en el manejo de la información local- global. Caso de estudio la disidencia en la frontera colombo-ecuatoriana. En Rodríguez-Castro, M., PérezSeijo, S. y Campos-Freire, F. (Eds.). La TV Pública en Europa: Innovación, Retos y Tendencias (133-149). Cuadernos Artesanos de Comunicación, cac 146. La Laguna (Tenerife): Latina. DOI: $10.4185 /$ cac146.
\end{abstract}

\section{Resumen}

Los atentados suscitados en la provincia de Esmeraldas en las ciudades de San Lorenzo y Mataje, se agudizaron a partir de la muerte del equipo de investigación de diario El Comercio en manos del grupo disidente Oliver Sinisterra, liderado por 'alias Guacho'. Esto convirtió al Ecuador en el centro de atención para los medios a nivel internacional. Esta investigación analiza el tratamiento de la información audiovisual que las cadenas de televisión: Caracol Noticias, El Espectador, Ecuavisa, RT y la BBC han realizado sobre el conflicto que Ecuador mantiene en la frontera norte con la disidencia colombiana. La metodología empleada es cualitativa, a través del análisis de contenido de la información publicada el 13 de abril de 2018 se evalúan tres 
indicadores: relevancia informativa, fuentes y enfoque. Las hipótesis que se plantean en la investigación son: las noticias emitidas en el entorno internacional fueron eco de la información transmitida por medios ecuatorianos o los medios colombianos se convirtieron en la primera fuente de información.

Palabras clave: noticias, agenda setting, medios de comunicación, periodismo, Ecuador.

\section{Introducción}

La expansión de la información televisiva establece diversas formas de consumo con percepciones diferentes. Es decir, la mirada del emisor sobre la realidad para transmitir su concepción de la misma. La mirada del telespectador o usuario sobre la oferta televisiva, y, en suma, sobre la interpretación que cada canal da de la realidad compleja (Cebrián Herreros, 2001:5).

La información es poder y los medios audiovisuales asumen este dominio con la interpretación de las imágenes, en algunos casos espectaculares, que provocan la atención de la audiencia. En este sentido, el audiovisual representa un formato, un recurso explotado por diversos medios que lo utilizan para informar y captar seguidores.

La información audiovisual, es sin duda la maquinaria esencial de los canales de televisión en abierto y en Internet, que compiten cada vez más con "portales y puntos de información que ofrecen imágenes en movimiento. Aunque ya son centenares los canales de televisión que emiten su señal por la red" y se encuentran a la espera de una "mayor implantación de las redes de banda ancha" (León, García, 2000). Mientras tanto la televisión en abierto continua vigente en el mercado de los medios y su impacto no pierde valor, es más competitivo. Marin (2017: 15) asegura que la tecnología e Internet han ayudado a que la televisión siga siendo un referente de credibilidad y de audiencia.

Las cadenas de televisión y en especial los productos informativos son parte de la evolución influida por "una mayor diversidad de contenido audiovisual disponible en cualquier momento, lugar y dispositivo. La audiencia en revolución se enfrenta a una oferta programática ampliada 
diversa y personalizable donde sus preferencias son satisfechas casi instantáneamente" (Ramos \& Ortega, 2017:706).

Con esta particularidad de lo instantáneo, se enmarcan los acontecimientos suscitados en el mes de marzo de 2018, en la frontera norte de Ecuador y Colombia con el secuestro de los periodistas ecuatorianos Javier Ortega, Paúl Rivas y Efraín Segarra (reportero, fotógrafo y conductor del Diario el Comercio respectivamente), por parte del grupo disidente de la guerrilla de las Farc 'Frente Oliver Sinisterra' al mando de alias 'Guacho'.

\section{Figura 1. Primera prueba de supervivencia periodistas ecuatorianos}

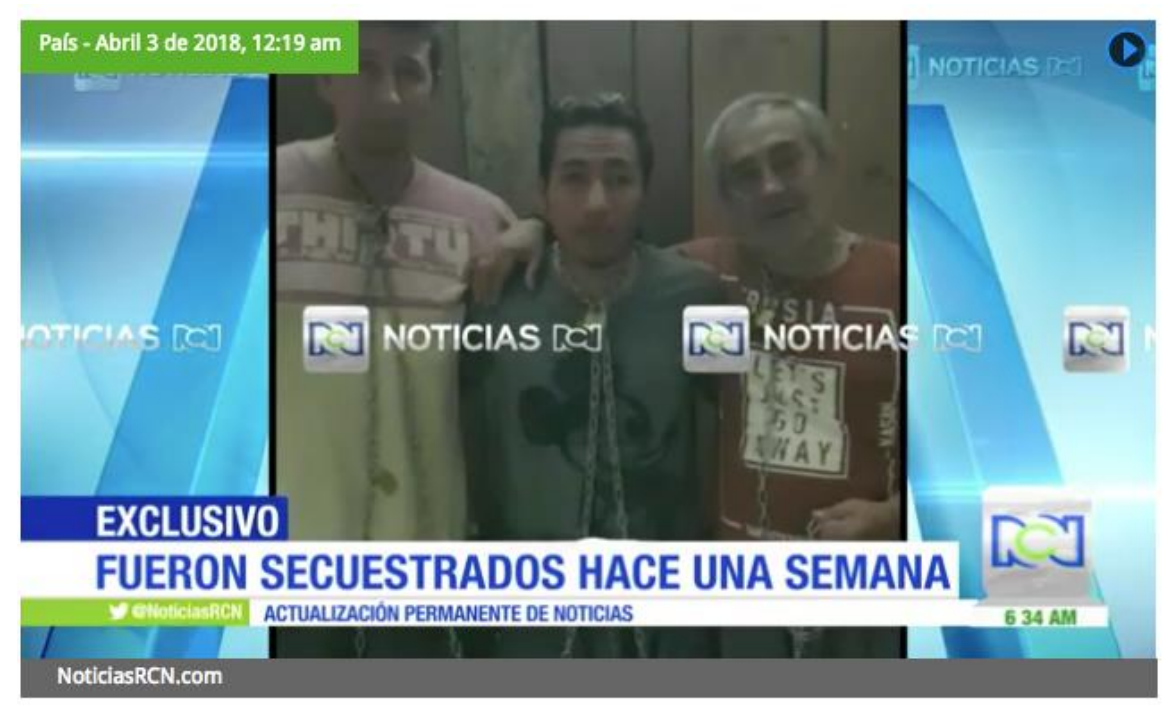

Fuente: Noticias RCN.com (Publicación del 3 de abril de 2018)

En este caso, la primera fuente de información que permitió conocer la ubicación y estado de los periodistas (la primera prueba de vida) fue un video de 22 segundos (Figura 1), en el cual los periodistas daban a conocer la negociación que los guerrilleros proponían al Estado ecuatoriano a cambio de sus vidas. RCN fue la primera cadena televisiva colombiana que dio a conocer estos testimonios considerados "off the record". Además, estas primicias periodísticas provocaron reacción por parte del gobierno ecuatoriano por cuanto se había decidido al interno del país la verificación de información antes de su difusión. 
Sin embargo, la información de último minuto lanzada por Noticias RCN se difundía en Ecuador conjuntamente con reportajes que relataban las actividades que este grupo de trabajo de Diario El Comercio habían efectuado horas antes de su desaparición, y la publicación de perfiles biográficos. NTN24 (2018) informó que las últimas imágenes en libertad del equipo del diario El Comercio fueron captadas el lunes 26 de marzo por cámaras de seguridad del hotel en el que se hospedaban al norte de Ecuador. Emprendieron una ruta de 20 minutos hacia Mataje, en la provincia de Esmeraldas, lugar en el cual fueron secuestrados. La información divulgada por RCN y NTN24 se produjo, a través de la alianza informativa con medios ecuatorianos de cobertura nacional, como es Teleamazonas y Ecuavisa.

Por otro lado, sobre este mismo caso el Diario El Tiempo de Bogotá publicó una primicia que resultó ser una fake news:

Dos días después, el 28 de marzo, cuando los periodistas llevaban cerca de 55 horas retenidos, el diario El Tiempo de Bogotá publicó la primicia de que los tres hombres habían sido liberados. El medio citaba "altas fuentes militares" y decía que los rehenes estaban en poder del Ejército ecuatoriano y en buen estado. El medio compartió la noticia en su cuenta de Twitter y fue retuiteada cientos de veces, aunque los Ministros de Defensa e Interior de Ecuador dijeron que no tenían información sobre ninguna liberación. El paso de las horas dejó claro que la noticia era falsa (The New York Times, 2018).

\section{Localidad versus Globalidad informativa}

La información local ha cobrado una importancia relevante en el proceso informativo, por cuanto, ésta, se distingue del escenario global por la proximidad con los hechos, situación que favorece a la sustentación de la verdad, dado que la comprobación periodística se da en algunos casos por la cercanía al territorio apoyada de la observación participante, lo que otorga un relato apegado a la realidad de los acontecimientos.

En cambio, lo global parte de lo local y, es a través de Internet, redes sociales de información, alianzas y colaboraciones entre medios regionales y mundiales que se establece la propagación de la noticia. La globalidad noticiosa depende, además, de la relevancia y la implicación 
de aspectos universales como los derechos humanos y en el caso de coberturas periodísticas el riesgo personal y la complicidad tecnológica para mantener los datos seguros.

El volumen y la sofisticación de los ataques contra los datos digitalizados de los periodistas están aumentando a un paso alarmante. En China los corresponsales extranjeros han visto sus computadoras personales infectadas con software de vigilancia que estaba oculto bajo la forma de adjuntos en mensajes de correo electrónico [...]. Las autoridades de países como Etiopía y Colombia han podido acceder a teléfonos, correos electrónicos y conversaciones de texto de periodistas (Smyth, 2012:17).

En este sentido, la información sobre el secuestro de los periodistas se viralizó y su difusión fue global, tanto los medios internacionales como los medios sociales hicieron eco de los acontecimientos locales. Junto a está ola de información se evidenció una filtración de imágenes sin editar que circulaba vía Whatsapp. Los medios televisivos de Ecuador y Colombia procedieron a la verificación, antes de certificar las imágenes que probaban la muerte del equipo de periodistas del Diario el Comercio (Figura 2).

Figura 2. Fotografías de periodistas ecuatorianos de Diario El Comercio

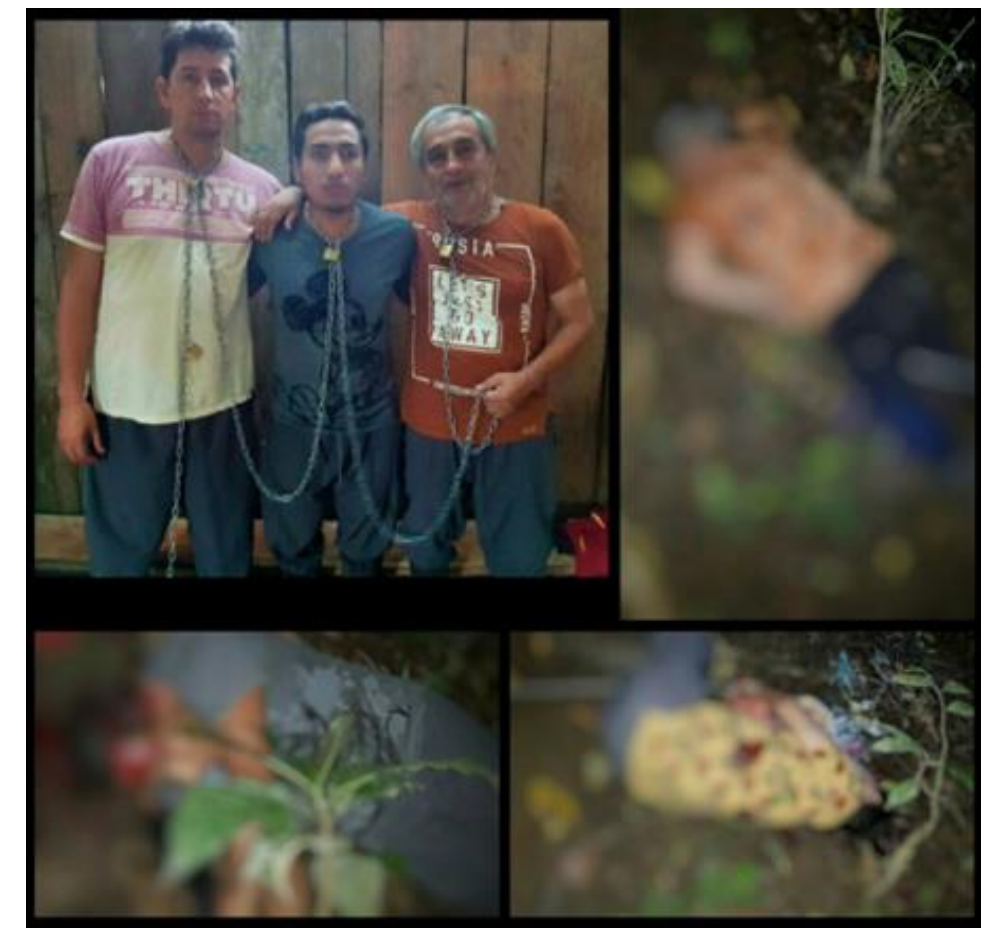

Fuente: Lasnoticias.co. Publicación 13 de abril de 2018 
El nefasto acontecimiento para el periodismo ecuatoriano produjo indignación, además este hecho llevó a que, la comisión de Derechos Colectivos de la Asamblea Nacional del Ecuador, plantee en la propuesta de cambios a la Ley de Comunicación la valorización de la profesión y más aún en casos de riesgo, entre otros puntos. La propuesta presentada por el Secretario de Comunicación a la presidenta de la Asamblea de Ecuador será evaluada como un asunto prioritario (El Universo, 2018).

\section{Metodología}

La investigación plantea el estudio de caso de las noticias publicadas el 13 de abril de 2018, día en el cual se confirmó la muerte del equipo periodístico del diario El Comercio. El objetivo se enmarca en el uso del audiovisual como recurso estratégico de la información.

Tabla 1. Muestra de noticias 13 de abril de 2018

\begin{tabular}{|c|c|c|}
\hline Medio & Titular & Links \\
\hline $\begin{array}{l}\text { Caracol } \\
\text { Noticias }\end{array}$ & $\begin{array}{l}\text { "Ecuador llora primer secuestro y } \\
\text { asesinato de periodistas de El } \\
\text { Comercio" }\end{array}$ & https://goo.gl/4nPsgY \\
\hline $\begin{array}{l}\text { E1 } \\
\text { Espectador }\end{array}$ & $\begin{array}{l}\text { "Confirman muerte de periodistas } \\
\text { ecuatorianos a manos de alias } \\
\text { Guacho" }\end{array}$ & $\begin{array}{l}\text { Emitido en directo } \\
\text { https://goo.gl/pnX9Nk }\end{array}$ \\
\hline Ecuavisa & $\begin{array}{l}\text { "Pronunciamiento de Presidente de } \\
\text { la República muerte periodistas de } \\
\text { El Comercio" }\end{array}$ & $\begin{array}{l}\text { Emitido en directo } \\
\text { https://goo.gl/x2iAco }\end{array}$ \\
\hline $\begin{array}{l}\text { RT en } \\
\text { español }\end{array}$ & $\begin{array}{l}\text { "Colombia: Medio recibe fotos de } \\
\text { cuerpos que podrían ser de los } 3 \\
\text { periodistas secuestrados en } \\
\text { Ecuador" }\end{array}$ & $\begin{array}{l}\text { Emitido en directo } \\
\text { https://goo.gl/MjUCa8 }\end{array}$ \\
\hline BBC & $\begin{array}{l}\text { "El gobierno de Ecuador confirma } \\
\text { la muerte de los tres miembros del } \\
\text { equipo de prensa de El Comercio } \\
\text { que fueron secuestrados por un } \\
\text { grupo disidente de las FARC }\end{array}$ & $\begin{array}{l}\text { Sección América Latina } \\
\text { https://goo.gl/C5d9sz }\end{array}$ \\
\hline
\end{tabular}

Fuente: Elaboración propia 
La muestra se determina con la selección de medios que realizaron la cobertura y seguimiento de la información desde el momento del secuestro de los periodistas. Los medios seleccionados fueron: dos medios colombianos Caracol Noticias, El Espectador; un medio televisivo ecuatoriano Ecuavisa; RT en español medio de origen ruso y la BBC emisora pública británica (Tabla 1).

Tabla 2. Parámetros del estudio de casos

\begin{tabular}{|c|c|c|}
\hline Generales & \multicolumn{2}{|c|}{ Específicos } \\
\hline \multirow{2}{*}{$\begin{array}{l}\text { Relevancia } \\
\text { Informativa }\end{array}$} & Relevancia Tópica & Eventos periódicos \\
\hline & Relevancia Intemporal & Fuera de la agenda settings \\
\hline \multirow{8}{*}{$\begin{array}{l}\text { Fuentes } \\
\text { informativas }\end{array}$} & Implícitas & Consultadas por la cadena \\
\hline & Explícitas & Directas o indirectas \\
\hline & Originaria & Qué convoca a los medios \\
\hline & Implicada/interesada & $\begin{array}{l}\text { Declaraciones de fuentes } \\
\text { directas e implicadas }\end{array}$ \\
\hline & Consultada & Contraste de información \\
\hline & Equilibradas & Testigos \\
\hline & Experta & Académicos \\
\hline & Encuestados & Opinión generalizada \\
\hline \multirow[t]{10}{*}{ Enfoque } & De enfrentamiento & $\begin{array}{l}\text { Carácter conflictivo de la } \\
\text { situación de los participantes }\end{array}$ \\
\hline & Conjetural & Perspectiva especulativa \\
\hline & Histórico & $\begin{array}{l}\text { Punto de vista explicativo o } \\
\text { cómo evoluciona }\end{array}$ \\
\hline & Perspectivista & $\begin{array}{l}\text { Repercusión del hecho en el } \\
\text { futuro }\end{array}$ \\
\hline & Consensual & Puntos de acuerdo \\
\hline & Competitivo & Posición ganadora o perdedora \\
\hline & Denunciador & $\begin{array}{l}\text { Enfocada desde una denuncia } \\
\text { (injusticia o error) }\end{array}$ \\
\hline & Documental & $\begin{array}{l}\text { Realidad en base a } \\
\text { declaraciones o información }\end{array}$ \\
\hline & Reactivo & $\begin{array}{l}\text { Respuesta o reacción de los } \\
\text { protagonistas }\end{array}$ \\
\hline & Interés Humano & Punto de vista emotivo \\
\hline
\end{tabular}

Fuente: Elaboración propia a partir de la propuesta de Fernández et. al., 2008

Para la recogida de datos se utilizó una ficha extendida diseñada de acuerdo a estudios previos sobre análisis de la información televisiva realizados por Fernández del Moral, Quesada, Sánchez Aranda y Fernández (2008) y del cual se extrajeron los siguientes parámetros (Tabla 1): relevancia informativa "que indica el grado de actualidad de la noticia. [...] Son noticias que por un lado denotan una elaboración al margen de lo que marcan las agencias y, por otro pueden significar falta 
de información de actualidad" (pp.,17). Fuentes informativas, importantes para evaluar la calidad y profesionalismo de la información que se emite y enfoque que permite determinar la orientación de la noticia (Tabla 2).

Las hipótesis de la investigación son: H1: las noticias emitidas en el entorno internacional fueron eco de la información transmitida por medios ecuatorianos o; $\mathrm{H} 2$ : los medios colombianos se convirtieron en la primera fuente de información.

\section{Análisis y discusión}

La muerte de los tres miembros del equipo periodístico del Diario el Comercio evidenció la falta de seguridad y garantías para ejercer el periodismo en zonas de frontera. La noticia del asesinato fue divulgada por medios nacionales e internacionales, los cuales desde diferentes perspectivas rechazaron lo sucedido.

En este sentido, el uso del audiovisual para la difusión de los hechos, es estratégico, por cuanto la integración de la imagen y sonido supone una recreación visual sensitiva y evoca cercanía con la narración. La información audiovisual ofrece inmediatez "con un relato más equilibrado entre la palabra, imagen y sonido y una mejor explotación ulterior" (Díaz Arias, 2008:179), debido a que el consumo del audiovisual se prolifera y domina en las diversas formas de comunicación mediática.

En esta investigación el nivel de análisis del audiovisual se lo plantea bajo los criterios establecidos para el tratamiento de información televisiva, acuñando directrices periodísticas que permiten catalogar la relevancia de la información, el contraste de la noticia con la identificación del tipo de fuentes y el enfoque.

El estudio de caso se centra en la información emitida el día 13 de abril por los medios: Caracol Noticias, El Espectador, Ecuavisa, RT en español y la BBC de este último se realizó el análisis de la versión impresa, el registro audiovisual no se localizó.

Los resultados iniciales de la observación determinaron que la información emitida por el medio ecuatoriano Ecuavisa ocupó mayor tiempo en pantalla, con la transmisión de la rueda de prensa convocada por el gobierno de Ecuador en la que se dio a conocer oficialmente la 
muerte de los periodistas de El Diario el Comercio. Este enlace en abierto aseguró sintonía y tiene concordancia con el 23.9\% de rating y share de Tv que la emisora registra según Kantar Media Ibope (le siguen en rating TC Televisión 22, 4\%, RTS, 14\%, Teleamazonas 11\%) (Obitel, 2017:191).

El segundo medio que presentó mayor tiempo de transmisión por Internet es El Espectador con 46 minutos, alcanzando un registro promedio de 40 mil visualizaciones. Finalmente, los medios que tuvieron un registro menor de cobertura fueron Caracol Noticias con 6 minutos y RT en español con 58 segundos, sin embargo, este último alcanzó un mayor registro de visualizaciones 67 mil en relación a Caracol Noticias.

Tabla 3. Tiempo y caracteres de análisis de noticias sobre secuestro de periodistas de E1 Comercio

\begin{tabular}{|c|c|c|c|}
\hline Medio & Titular & $\begin{array}{l}\text { Tiempo } \\
\text { minutos }\end{array}$ & $\begin{array}{c}\text { Registro de } \\
\text { Visualizaciones }\end{array}$ \\
\hline $\begin{array}{l}\text { Caracol } \\
\text { Noticias }\end{array}$ & $\begin{array}{l}\text { "Ecuador llora primer } \\
\text { secuestro y asesinato de } \\
\text { periodistas de El Comercio" }\end{array}$ & 6 & 57.908 \\
\hline $\begin{array}{l}\text { E1 } \\
\text { Espectador }\end{array}$ & $\begin{array}{l}\text { "Confirman muerte de } \\
\text { periodistas ecuatorianos a } \\
\text { manos de alias Guacho" }\end{array}$ & $46^{\prime}$ & 40.641 \\
\hline Ecuavisa & $\begin{array}{l}\text { "Pronunciamiento de } \\
\text { Presidente de la República } \\
\text { muerte periodistas de El } \\
\text { Comercio" }\end{array}$ & $60 ’ 43^{\prime \prime}$ & $\begin{array}{l}\text { Señal en abierto } \\
\text { y transmisión en } \\
\text { vivo Internet }\end{array}$ \\
\hline $\begin{array}{ll}\text { RT } & \text { en } \\
\text { español } & \end{array}$ & $\begin{array}{l}\text { "Colombia: Medio recibe } \\
\text { fotos de cuerpos que } \\
\text { podrían ser de los } 3 \\
\text { periodistas secuestrados en } \\
\text { Ecuador" }\end{array}$ & $58 ”$ & 67.737 \\
\hline
\end{tabular}

Fuente: Elaboración propia

Por otro lado, la información publicada por la BBC en la sección América Latina con 3802 caracteres (Tabla 4) fue compartida en medios sociales, la visibilidad de BBC se garantiza por el número de 
Me gusta (4 millones) y de seguidores 4.1 millones alcanzados en Facebook.

Tabla 4. Caracteres de análisis de noticia BBC

\begin{tabular}{llll}
\hline Medio & Titular & Caracteres & Redes \\
\hline BBC & "El gobierno de Ecuador 3802 & Twitter \\
& $\begin{array}{l}\text { confirma la muerte de los tres } \\
\text { miembros del equipo de prensa } \\
\text { de El Comercio que fueron } \\
\text { secuestrados por un grupo } \\
\text { disidente de las FARC }\end{array}$ & Facebook \\
& & Menéame \\
\end{tabular}

Fuente: Elaboración propia

En lo referente a la relevancia informativa se observa que todos los medios analizados se guiaron por el criterio de actualidad, y el resultado de la observación indica que la información publicada tiene como característica el parámetro 'tópica' porque hacen referencia a un evento periódico con cobertura continua, es decir desde que se produjo el secuestro de los periodistas de diario El Comercio hasta el su fallecimiento, el 13 de abril.

Tabla 5. Parámetro de análisis Fuentes Informativas

\begin{tabular}{ccccccc}
\hline Parámetros de análisis & $\begin{array}{c}\text { Caracol } \\
\text { Noticias }\end{array}$ & $\begin{array}{c}\text { E1 } \\
\text { Espectador }\end{array}$ & Ecuavisa & RT & BBC \\
\hline & Implícitas & $\mathrm{x}$ & & $\mathrm{x}$ & & $\mathrm{x}$ \\
\cline { 2 - 7 } & Explícitas & & $\mathrm{x}$ & & & \\
\cline { 2 - 7 } $\begin{array}{c}\text { Fuentes } \\
\text { Informativas }\end{array}$ & Originarias & $\mathrm{x}$ & $\mathrm{x}$ & $\mathrm{x}$ & $\mathrm{x}$ & $\mathrm{x}$ \\
\cline { 2 - 7 } & Implicadas & & & $\mathrm{x}$ & & $\mathrm{x}$ \\
\cline { 2 - 7 } & Consultadas & $\mathrm{x}$ & $\mathrm{x}$ & $\mathrm{x}$ & & \\
\cline { 2 - 7 } & Equilibradas & & & & & \\
\cline { 2 - 7 } & Experta & & $\mathrm{x}$ & & & $\mathrm{x}$ \\
\hline & Encuestados & & $\mathrm{x}$ & $\mathrm{x}$ & & \\
\hline
\end{tabular}

Fuente: Elaboración propia 
Así también, en los registros audiovisuales (se incluye la BBC) se destacó el uso de fuentes informativas "originarias" (Tabla 5) es decir, ninguno de los medios estudiados se arriesgó a publicar noticias a priori, decidieron esperar el pronunciamiento del gobierno de Ecuador (a través de una rueda de prensa), como una buena práctica de verificación y de utilización de fuentes oficiales. El medio que utilizó una diversidad de fuentes (implícitas, implicadas, consultadas, encuestados) fue Ecuavisa.

Entre las fuentes se destacan periodistas ecuatorianos y extranjeros como Alex Cevallos quien expresó que la muerte de los periodistas ha causado molestia y consternación entre los profesionales de la comunicación "porque son las familias de estos tres periodistas que sufren, estamos sufriendo como país" (Ecuavisa 2018). Jean Paúl Bardellini corresponsal de NT24 Colombia (2018) manifiestó "los que han estado cubriendo el conflicto en la frontera, durante algunos años, sabían que esto pasaría, simplemente pasó y el gobierno no estaba preparado y nuestras fuerzas armadas han sido debilitadas y ahora tenemos narcoterroristas en la frontera de Ecuador matando gente" (Ecuavisa, 2018).

Gráfico 1. Línea de tiempo. Desarrollo de la noticia Ecuavisa
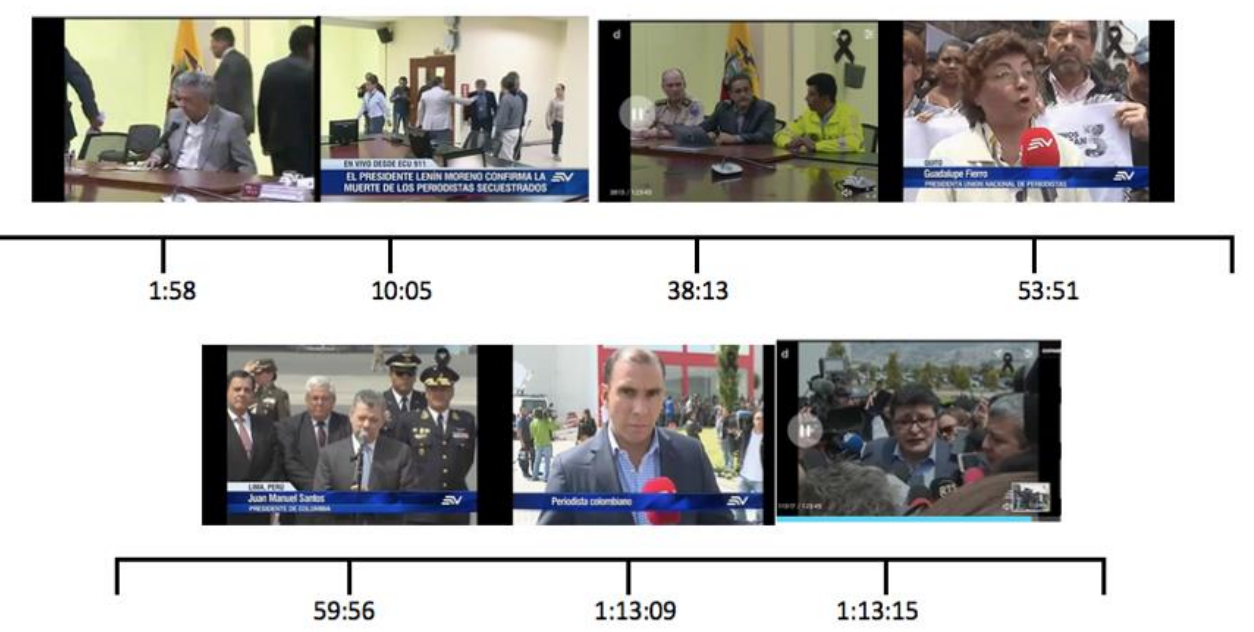

Fuente: Elaboración propia.

Asimismo, se destacan pronunciamientos relacionados con la crítica realizada por varios organismos como Fundamedios, Fundación para la libertad (Gráfico 1), al gobierno de Colombia, en primera instancia, por el poco interés asumido con el conflicto "señalando reiteradamente 
que esto es un asunto ecuatoriano, [el] Guacho es ecuatoriano, los periodistas son ecuatorianos, están en territorio ecuatoriano y por lo tanto el problema es de Ecuador"(Ricaurte, Ecuavisa, 2018).

Otro de los medios que registra una variada utilización de fuentes, como parte de un proceso de contrastación periodística es el medio colombiano El Espectador, recogió el pronunciamiento del gobierno de Ecuador, a través de un enlace en directo vía Internet, para complementar realizó una cobertura periodística en territorio colombiano, destacándose la solidaridad de los periodistas y personas que habitan en la frontera por los hechos suscitados. Entre las infografías y declaraciones se imprimen: "Periodistas del Diario El Comercio de Ecuador, fueron asesinados por disidencia de las Farc". "Estamos de luto, pero no vamos a dejarnos amedrentar hoy más que nunca pido al país la unidad por la paz, unidos por la paz. Ese llamado a la paz en ninguna instancia significa el hecho de que se quiera limitar la libertad de expresar lo que uno desee, la libertad de expresión..." (El Espectador, Santos, 2018).

\section{Gráfico 2. Línea de tiempo. Desarrollo de la noticia E1 Espectador}

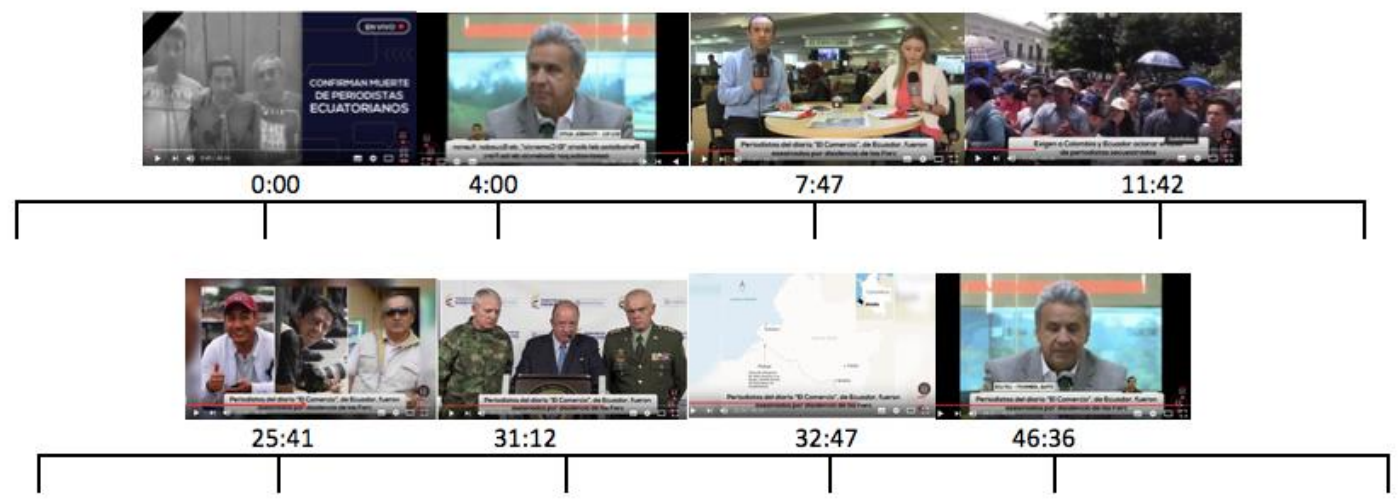

Fuente: Elaboración propia.

En lo que respecta al análisis del enfoque (Tabla 6), en todos los medios observados (Caracol Noticias, El Espectador, Ecuavisa, RT, Ecuavisa), la información publicada es de tipo 'reactivo' y de interés humano, es decir, el relato se construye sobre la base de respuestas y reacciones de los principales protagonistas. En la información emitida se aplica el punto de vista emotivo, este se evidencia principalmente en las declaraciones sobre las cuales se generaron las noticias: 
Lamento informar que se han cumplido las 24 horas de plazo establecido, no hemos recibido pruebas de vida y lamentablemente tenemos información que confirma el asesinato de nuestros compatriotas. Más alla de los esfuerzos realizados se ha confirmado que estos criminales parecería que nunca tuvieron la voluntad de entregarlos sanos y salvos, es muy probable que ... lo único que hayan querido es ganar tiempo, por lo tanto he solicitado al consejo de seguridad pública del Estado [...] el levantamiento de reserva de información pertinente para que el pueblo ecuatoriano conozca los esfuerzos del Estado por garantizar la vida de nuestros compatriotas. (Ecuavisa, Moreno, 2018).

Así también, se registra el uso del enfoque consensual en los relatos de Ecuavisa, RT y la BBC, estos resaltan los acontecimeintos más relavantes que marcaron el rumbo del secuestro, reacciones y reclamos de los familiares y de las personas que se unieron a la protesta en pro de la defensa y el derecho a la vida.

Tabla 6. Parámetro de análisis Enfoque

\begin{tabular}{|c|c|c|c|c|c|c|}
\hline $\begin{array}{l}\text { Parámetros } \\
\text { de análisis }\end{array}$ & & $\begin{array}{l}\text { Caracol } \\
\text { Noticias }\end{array}$ & $\begin{array}{c}\text { El } \\
\text { Espectador }\end{array}$ & Ecuavisa & RT & BBC \\
\hline \multirow{10}{*}{ Enfoque } & $\begin{array}{c}\text { De } \\
\text { enfrentamiento }\end{array}$ & & $\mathrm{x}$ & $\mathrm{x}$ & & \\
\hline & Conjetural & & & & & \\
\hline & Histórico & & & & & $\mathrm{x}$ \\
\hline & Perspectivista & $\mathrm{x}$ & & & & \\
\hline & Consensual & & & $\mathrm{x}$ & $\mathrm{x}$ & $\mathrm{x}$ \\
\hline & Competitivo & & & & & \\
\hline & Denunciador & & & & & \\
\hline & Documental & & & & & \\
\hline & Reactivo & $\mathrm{x}$ & $\mathrm{x}$ & $\mathrm{x}$ & $\mathrm{x}$ & $\mathrm{x}$ \\
\hline & $\begin{array}{l}\text { Interés } \\
\text { Humano }\end{array}$ & $\mathrm{x}$ & $\mathrm{x}$ & $\mathrm{x}$ & & $\mathrm{x}$ \\
\hline
\end{tabular}

Fuente: Elaboración propia.

Finalmente, en todo el proceso informativo lo fundamental es la verificación, por ejemplo, la $\mathrm{BBC}$ el momento que decide publicar la 
información lo hace verificando con varias fuentes, señalan puntualmente “(...) la noticia bien verificada esa es nuestra prioridad, no la rapidez, por supuesto tenemos que ser rápidos, tratamos de hacerlo lo más pronto posible" (Chacón, s/f). En este sentido, la inmediatez pasa a un segundo plano, puesto que en las prácticas periodísticas actuales el tema de la credibilidad y la seriedad ante el cúmulo de información, trascienden y su vigencia depende principalmente de un manejo adecuado de las fuentes.

En el caso de la información que fue emitida como fake news, se pudo corroborar en la observación que esta provocó: desacuerdos entre las dos naciones, el quebranto de la diplomacia, de la credibilidad del medio y lo que Fernández-García considera la "pérdida de centralidad de la fuente", y con lo cual "se institucionaliza la mentira con sobreinformación y una gran abundancia de fuentes" siendo necesario la comprobación de las noticias para distinguir falsedades (2017: 73). De ahí la importancia de la verificación y contrastación de fuentes en la construcción de la noticia y con lo cual se fortalece la credibilidad de cualquier medio.

\section{Conclusiones}

Las hipótesis planteadas al inicio de la investigación fueron confirmadas. Los medios de comunicación internacionales transmitieron la información generada por los medios ecuatorianos. A través de una cadena nacional, el presidente de la República de Ecuador confirmaba la muerte de los periodistas, esta declaración se convirtió en la primera fuente de información.

$\mathrm{Al}$ ser un tema sensible este tipo de noticias permiten que las agendas informativas tengan consenso social, mucho más cuando esta clase de tópicos (secuestro) se desarrollan en un país que no ha sufrido un conflicto con guerrillas. Las estrategias informativas deben ser manejadas cuidadosamente o pueden provocar confrontaciones o desacuerdos como en un primero momento una noticia falsa dio paso al quebranto en la diplomacia entre los dos países.

Todos los medios de comunicación observados presentaron la información con un nivel de relevancia tópica, es decir, mantenían la 
información vigente en la agenda setting, a través de la consulta a fuentes implicadas: familiares y fuentes oficiales.

Se debe considerar que actualmente la tecnología activa diferentes canales informativos y que los periodistas no son los únicos agentes con capacidad de informar. El trabajo que deben desarrollar cobra más fuerza por la capacidad de contraste y verificación de fuentes que deben hacer.

El enfoque que manejaron todos los medios en este tipo de información fue de carácter reactivo e interés humano, por la sensibilidad que puede despertar en la población, se puede confirmar que los medios cumplen con los preceptos del periodismo en el tratamiento de la información con temas delicados.

\section{Referencias bibliográficas}

BBC (Publicación del 13 de abril de 2018). El gobierno de Ecuador confirma la muerte de los tres miembros del equipo de prensa de El Comercio que fueron secuestrados por un grupo disidente de las FARC. Disponible en: https://goo.gl/C5d9sz

BBC (s/f). Las redes sociales como herramienta periodística.

Recuperado al 2 de agosto de 2018. Disponible en: https://goo.gl/5fXacw

Caracol Noticias (Publicación del 13 de abril de 2018). Ecuador llora primer secuestro y asesinato de periodistas de El Comercio. Disponible en: https://goo.gl/4nPsgY

Chacón, R. Periodista BBC. (s/f). Las redes sociales como herramienta periodística. Recuperado al 2 agosto de 2018. Disponible en: https://goo.gl/SYzt4G

Cebrián Herreros, M. (2001). Aprender a ver y analizar la información audiovisual. Revista Comunicar. Núm. 017. 15-20. HuelvaEspaña. Disponible en: https://goo.gl/7tSpLp

Díaz Arias, R. (2008). Análisis y tratamiento de las fuentes audiovisuales. Revista Documentación de las Ciencias de la Información, $\mathrm{N}^{\mathrm{o}}$ 31. Disponible en: https://goo.gl/si1sRy 
D Ramos Méndez, F Ortega-Mohedano (2017): “La revolución en los hábitos de uso y consumo de vídeo en teléfonos inteligentes entre usuarios Millenials, la encrucijada revelada". Revista Latina de Comunicación Social, 72, pp. 704 a 718. Disponible en: https://goo.gl/XVQ9Ym DOI: 10.4185/RLCS-20171187

El Universo (publicación 21 de mayo de 2018). Propuesta de reformas a la Ley de Comunicación elimina el linchamiento mediático. Recuperado al 2 de agosto de 2018. Disponible en: https://goo.gl/tijC3y

El Espectador. (Publicación del 13 de abril de 2018). Confirman muerte de periodistas ecuatorianos a manos de alias Guacho. Disponible en: https://goo.gl/pnX9Nk

Ecuavisa (Publicación del 13 de abril de 2018). Pronunciamiento de Presidente de la República muerte periodistas de El Comercio. Disponible en: https://goo.gl/x2iAco

Fernández-García, N. (2017). Fake News: una oportunidad para la alfabetización mediática. Revista Nueva Sociedad No 269, mayo-junio 2017. Disponible en: https:/ /goo.gl/AJ8MxA

Férnandez del Moral, J., Quesada, M., Sánchez Aranda, J. J. y Fernández, A. (2008). El análsis información televisiva. Hacia una medida de la calidad periodística. Cie Inversiones Editoriales Dissot: Madrid- España.

León, Bienvenido \& García Avilés, José Alberto (2000). La información audivisual interactiva en el entorno de la convergencia digital: desarrollo y rasgos distintivos. Comuncación y Sociedad. Vol XIII. Núm. 2 141-179. Navarra-España. Disponible en: https://goo.gl/Po6gCY

Marin, C. (2017). El informativo de Televisión. Barcelona: Gedisa .

Observatorio Ibero-Americano de Ficción Televisiva. Obitel 2017. Una década de ficción televisiva en Iberoamérica. Análisis de diez años de Obitel (2007-2016). Editora Sulina: Brasil

RT en español. (Publicación del 13 de abril de 2018). Colombia: Medio recibe fotos de cuerpos que podrían ser de los 3 
periodistas secuestrados en Ecuador.. Disponible en: https://goo.gl/MjUCa8

Smyth, F. (2012). Manual de Seguridad para Periodistas. Cubriendo las noticias en un mundo peligroso y cambiante. Cómite para la protección de los Periodistas CPJ. Disponible en: https://goo.gl/9FyeZL

The New York Times (Publicación de José María León, del 4 de abril de 2017). Tres periodistas ecuatorianos secuestrados: dos visiones sobre el manejo de la información. Disponible en: https://goo.gl/J9apMA 



\title{
Analogía del ecosistema televisivo español e italiano (TVE vs. RAI)
}

\author{
Javier Pérez Sánchez \\ Universidad Europea de Madrid
}

PARA CITAR: Pérez Sánchez, J. (2018). Analogía del ecosistema televisivo español e italiano (TVE vs. RAI). En Rodríguez-Castro, M., Pérez-Seijo, S. y Campos-Freire, F. (Eds.). La TV Pública en Europa: Innovación, Retos y Tendencias (151-174). Cuadernos Artesanos de Comunicación, cac 146. La Laguna (Tenerife): Latina. DOI: $10.4185 /$ cac146.

\section{Resumen}

Tanto en España como en Italia, las plataformas audiovisuales "a la carta" han ido irrumpiendo al mismo tiempo en el mercado televisivo. Son muchas las similitudes del entorno televisivo entre estos dos estados europeos, tanto a nivel programático y empresarial, como de consumo de productos audiovisuales. Este estudio tiene como objetivo definir las principales diferencias, consecuencias, amenazas y oportunidades, que poseen los operadores nacionales públicos frente a estos nuevos competidores internacionales en un ecosistema televisivo híbrido. Esta investigación pretende determinar las diferencias y similitudes actuales entre la televisión en abierto española e italiana, principalmente entre los canales públicos de la RAI1 y La1. Asimismo, se expone cómo ha afectado la implantación de Netflix y otros operadores on demand al modo de consumo televisivo en ambos países, detectando las principales acciones y oportunidades que poseen los modelos de televisión pública en abierto, frente a los nuevos sujetos audiovisuales y la competencia de la televisión privada en abierto. 
Palabras clave: TVE, RAI, ecosistema televisivo, híbrido, televisión pública, Italia, España.

\section{Introducción}

España e Italia guardan multitud de similitudes televisivas, tanto en el tipo de programas o formatos que se consumen, como en el sistema programático y empresarial que existe. Sirva como muestra que tanto Corporación Radio Televisión Española (CRTVE) como el Grupo de Radiotelevisione Italiana (RAI) están enmarcadas dentro del Modelo Mediterráneo o Pluralista Polarizado (Pavani, 2015: 463) en cuanto a la televisión pública se refiere.

No es muy diferente en lo que respecta a la televisión privada, puesto que el accionariado italiano en los grandes grupos de televisión españoles es mayoritario o extensamente representativo. Existen similitudes transfronterizas, como que suelen coincidir los formatos de éxito en ambos países, a consecuencia de un mercado global televisivo, así como los resultados que obtienen de audiencia estos programas. Ocurre algo parecido con los operadores tradicionales de la televisión de pago, donde existe una empresa dominante por encima del resto, que en el caso español es Movistar+ (antiguo Canal+) y en Italia es Sky. $\mathrm{Si}$ bien, en todos estos aspectos, existen matices que marcan algunas diferencias como se verá más adelante.

El Diccionario de la Real Academia Española (2001) define "Analogía" como: "Relación de semejanza entre cosas distintas. Razonamiento basado en la existencia de atributos semejantes en seres o cosas diferentes". Y los dos entornos o "ecosistemas" televisivos español e italiano son una analogía, puesto que tienen multitud de semejanzas, pero en realidad son dos sistemas en su naturaleza diferentes.

Los operadores de televisión llevan unos años adaptándose a un entorno híbrido de consumo audiovisual, siendo especialmente notable en los canales de emisión en abierto. En España, sobre todo en 2017 y 2018, estos canales han sufrido un descenso brusco de espectadores en el modo de visionado lineal o programado, mientras que el consumo 
audiovisual total ha seguido creciendo. Mientras, en Italia se ha mantenido el "status quo", consiguiendo las similares cifras de audiencia en estos últimos años, no notándose el impacto de las plataformas a la carta y los relativamente nuevos operadores.

Sirva de ejemplo la siguiente tabla para ver la variación del año 2016 a finales del 2017 de los espectadores en primetime (España de 22:30 a 24:30; Italia de 20:30 a 22:30) de los 5 principales canales más vistos en abierto:

Tabla 1. Media de espectadores en Prime Time

\begin{tabular}{|l|l|l|l|l|l|}
\hline \multicolumn{2}{|l|}{ ESPAÑA } & \multicolumn{2}{l|}{ ITALIA } \\
\hline CANAL & $\begin{array}{l}\text { Audiencia } \\
\text { Media } \\
\text { primetime } \\
2016\end{array}$ & $\begin{array}{l}\text { Audiencia } \\
\text { Media } \\
\text { primetime } \\
2017\end{array}$ & CANAL & $\begin{array}{l}\text { Audiencia } \\
\text { Media } \\
\text { primetime } \\
2016\end{array}$ & $\begin{array}{l}\text { Audiencia } \\
\text { Media } \\
\text { primetime } \\
2017\end{array}$ \\
\hline La 1 & 1.869 .783 & 1.841 .986 & RAI 1 & 4.544 .979 & 4.673 .098 \\
\hline Antena 3 & 2.260 .738 & 2.124 .093 & RAI 2 & 1.770 .514 & 1.760 .998 \\
\hline Cuatro & 1.053 .878 & 1.062 .046 & RAI 3 & 1.653 .324 & 1.478 .731 \\
\hline Telecinco & 2.617 .695 & 2.256 .846 & Canale 5 & 3.664 .511 & 3.971 .152 \\
\hline La Sexta & 1.308 .848 & 1.178 .207 & Italia 1 & 1.351 .068 & 1.434 .708 \\
\hline $\begin{array}{l}\text { TOTAL } \\
\text { TV }\end{array}$ & 16.998 .026 & 16.594 .477 & $\begin{array}{l}\text { TOTAL } \\
\text { TV }\end{array}$ & 24.578 .773 & 25.117 .928 \\
\hline
\end{tabular}

Fuente: Elaboración propia con datos de Barlovento Comunicación y Auditel Italia.

Como se puede observar, ha habido un descenso de espectadores en el caso español, y con los datos del 2018 se acentúan aún más, mientras en Italia se mantienen estables o incluso crecen entre el 2016 y 2017. Esto se debe principalmente a una serie de singularidades propias entre la televisión española y la italiana, que se analizará en el apartado sobre "las diferencias entre el sistema televisivo italiano y español". Por ejemplo, en España regularmente en los primeros cuatro meses de 2018 se está registrando en torno a 15.582 .175 espectadores en prime time (media realizada con datos de Kantar Media y Barlovento Comunicación), teniendo en cuenta además que enero y febrero son 
los meses de mayor consumo televisivo. Se puede hablar por tanto de una bajada de un millón de espectadores más respecto al 2017 en lo que va de año en el prime time. Algo similar está ocurriendo en Italia, donde se ha notado por primera vez un descenso moderado en el número de espectadores de la televisión tradicional, obteniendo una media de audiencia en prime time de 23.759.476 espectadores, más de un millón menos que el periodo anterior (media realizada con los datos de audiencia de Auditel). Ambos países han comenzado el 2018 con pérdidas relativamente significativas de espectadores, a pesar de que este año, y los dos próximos, debería haberse estabilizado el mercado televisivo tras la llegada de los operadores OTT, según algunos informes como el de Ericsson Consumer Lab, debiendo ser moderada la fuga de espectadores entre la televisión programada y los contenidos bajo demanda.

Bien es cierto que a nivel mundial se ha producido un cambio de costumbres a la hora de consumir productos audiovisuales. Ya no se limita solo al visionado a través de la ventana de la televisión, sino que los dispositivos móviles (smartphones, tablets, portátiles, etc..) y las propias Smart TV han propiciado que el consumo a la carta y personalizado sea muy relevante en el actual panorama televisivo. Por todo ello, hay que hablar del denominado consumo mixto o "Ecosistema televisivo híbrido". Este nuevo panorama audiovisual ha obligado a actualizarse y adaptarse también a los servicios públicos de radiotelevisión a nivel mundial.

\section{Metodología}

La metodología empleada para realizar este estudio es principalmente una metodología cualitativa. En esta metodología cobra especial relevancia el uso de "estudio de caso", en un proceso que se realiza

estableciendo una serie de comparaciones extrapolables o generalizables. De esta manera, realizando un estudio "in situ" del panorama televisivo italiano y español, esta metodología proporciona los factores claves de las similitudes y diferencias del panorama televisivo en ambos países. Como menciona Santana Leitner (2013), este "estudio de caso" se elabora a raíz de una observación a nivel agregado y directa, es decir, a través de un conjunto de items a nivel local, regional y nacional en una observación directamente realizada 
por el investigador "in situ". Asimismo, como menciona este autor: Los estudios de caso sirven para obtener unos resultados de un determinado momento en el espacio y el tiempo. Dado que el campo televisivo, a causa de la innovación tecnológica y los cambios paulatinos en los hábitos de consumo de los espectadores, hacen que ceñir a este último año la comparativa de ambas Corporaciones públicas de Radiotelevisión nacionales sea lo más razonable, medible y contrastable con el fin de obtener unas conclusiones fiables y lo más aproximadas a la realidad de ambos sistemas televisivos. Para ello, se ha generado un marco de comparación que proporcione unos resultados acotados y delimitados en el espacio-tiempo.

\section{Ecosistema televisivo híbrido}

La palabra "ecosistema" nos lleva a pensar en un concepto biológico, y en realidad el sistema televisivo actual no estaría muy alejado en cuanto a su forma de funcionar. Como comentan De Pascalis y Pescatore (2018): “Adopta una forma ecosistémica tanto a nivel de diseño como en referencia a las dinámicas de interacción entre sus múltiples elementos, y en particular en lo que respecta a sus modalidades de evolución a lo largo del tiempo, inspiradas por modelos de transformación ecológica y orgánica". Hay que entender este entorno televisivo como un todo compuesto por "organismos" y éste a su vez por "células" que lo forman, siendo los "organismos" las plataformas y los operadores audiovisuales, y las "células" los contenidos que se alimentan de las "moléculas", que son los espectadores. Por ejemplo, como dice Gloria Saló (2003) los formatos audiovisuales siempre "nacen, se establecen, se reproducen y mueren" como cualquier ser vivo, y efectivamente los formatos televisivos son creados o encargados por un operador a un equipo creativo interno o externo de una productora (nacen); luego se emiten o distribuyen por los distintos sistemas actuales de forma temporal (se establecen); si funcionan muy bien en cuanto a la audiencia aparecen programas o formatos similares en el resto de operadores y en el mismo (se reproducen); y finalmente se agotan por su propia explotación, no obteniendo los resultados de audiencia mínimos (mueren). En este último punto, donde habla de la muerte de los formatos, existe una variante que es "resucitar", gracias a las nuevas tecnologías, multitud de formatos y productos audiovisuales están teniendo varias "vidas" extras, bien por modas o 
por volver a enganchar años después al espectador de nuevo. De igual modo, y sobre todo en la televisión pública existen formatos donde se alarga la vida de forma casi perenne, bien por prestigio o por tradición programática del programa en cuestión.

A nivel global la convivencia de operadores audiovisuales con contenidos exclusivamente a la carta y canales tradicionales de televisión es una realidad. El estudio de Ericsson ConsumerLab de "Tv and Media 2017' demuestra que más del 50\% del consumo audiovisual general se realiza a través de las denominadas segundas pantallas (smartphones, tablets, ordenador, etc.). Esto explica en parte los datos expuestos en el anterior punto, aunque el hecho de que se visualice en otras pantallas ajenas al televisor, no significa que no se consuma televisión tradicional, ya que en algunos casos los usuarios de estos dispositivos móviles terminan visualizando contenido lineal programado por los operadores de televisión.

\section{Ilustración 1. Distribución del consumo audiovisual por dispositivos}
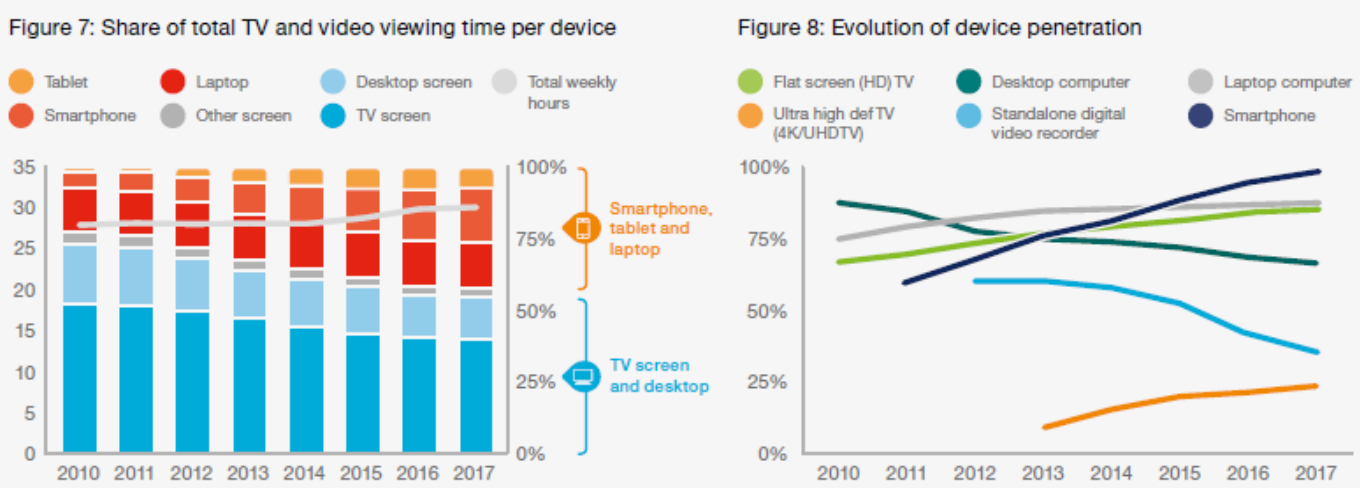

Source: Ericsson ConsumerLab, TV and Media, 2017

Base: Population aged 16-69 that watches TV/video at least weekly and has broadband at home, in Brazil. Canada, China, Germary, India, Italy, Russia, South Korea.

Fuente: Ericsson ConsumerLab (2017: 7)

Sin embargo, en la mayoría de los casos la utilización de segundas pantallas lleva a consumir productos a la carta o bajo demanda, ya sea de operadores televisivos tradicionales en abierto o de pago (a través de apps o páginas webs) como de los operadores exclusivamente OTT (Over the Top) u on-demand. El mismo informe de Ericsson también realiza una predicción para el 2020, donde habla de que ya se ha estabilizado y los cambios que se puedan producir serán moderados o leves, manteniéndose para los próximos años la actual distribución del 
consumo audiovisual, y solo creciendo de manera relevante la oferta y demanda de los contenidos en realidad virtual.

En este mismo sentido es necesario hablar también del cambio que se produjo en el panorama audiovisual hace ya unos años, y que ha derivado a la presente distribución de consumo mixto, y es la conversión de espectador en usuario o incluso en "prosumidor". El concepto de prosumer, o prosumidor, fue nombrado por primera vez en 1980 por Alvin Toffler. Basado en la teoría de la obra de Toffler de La tercera Ola, y adaptado al campo televisivo, es el prosumidor el que lleva a un sistema de convergencia donde el usuario o consumidor audiovisual cobra un papel activo, tanto en su consumo como en la distribución e incluso en la producción. "La divergencia y los espectadores de nicho de los medios son la consecuencia de una evolución completa del paradigma de la circulación en el escaparate mediático contemporáneo. El sistema tradicional de difusión se basa en una relación jerárquica entre la producción y el público. La producción, de hecho, ejerce control sobre el tiempo de consumo y los canales a través de la programación o el sistema de ventanas de distribución. El fenómeno de la convergencia rompe esta jerarquía: el proceso de digitalización y la transición de un modelo relacional de uno a uno que provoca una fuerte descentralización y transfiere a manos del usuario el control sobre el momento del visionado. A su vez, este control ejercido por el usuario se refleja en el aparato narrativo original y en un diseño cada vez más necesariamente ecosistémico" (Innocenti, 2018).

El uso de estrategias o narrativas cross-media, y el posicionamiento de los canales de televisión tradicionales en diversas plataformas on-demand viene dado porque "la influencia (de las OTT) es comúnmente recíproca. Mientras las prácticas de las OTT se han convertido en el nuevo estándar competitivo, los operadores de televisión tienen que introducirse en el campo de las estrategias de adaptación que implican los modelos empresariales y de distribución, transformándolos en servicios y contenidos en "sistemas". [...]En este paradigma en el que se ha pasado de la transmisión televisiva al suministro de "sistemas", los operadores de televisión se convierten en diseñadores de una "experiencia de usuario", cambiando la estrategia basada en la construcción de una red de servicio televisivo y en la multiplicación de los puntos de acceso a la emisión [...] hacia una conversión de un 
servicio OTT" (Brembilla, 2018). En otras palabras, al final los canales de televisión, para sobrevivir y no perder fidelidad sobre sus contenidos o productos (ya no hablamos de su emisión lineal), han tenido que convertirse igualmente en operadoras audiovisuales a la carta. Esta conversión ha hecho crecer también la calidad de los productos audiovisuales producidos por las cadenas tradicionales de televisión, sobre todo en lo que se refiere a ficción televisiva, dado que es donde mayor competencia y pérdida han tenido con las OTT, llegando a crear productos "Premium" y exclusivos similares a estas plataformas.

Esto ha llevado a que se esté viviendo la edad dorada de la ficción a nivel mundial, donde exista un gran número de producciones seriadas con una calidad e inversión superior a la industria del cine en algunos casos. Este tipo de estrategia mediática busca que el usuario tenga la percepción de que los canales de televisión y las plataformas OTT ofrezcan unas ventas de experiencias al espectador más que un servicio audiovisual, otorgando un mayor prestigio a sus contenidos y pudiéndolos rentabilizar, que para Luca Rosati es lo siguiente: "La economía de la experiencia nace como respuesta a la sobre-bonanza y a la consiguiente masificación de la oferta, para lo cual hace falta una igual transformación de parte del público.

Este hecho se produce en los años setenta y se intensifica en los últimos años de la nueva economía." (Rosati, 2018). La economía de la experiencia es un término acuñado por Pine II y Gilmore (1999) que consiste en transformar la materia prima o producto en una experiencia para el usuario, aumentando así el valor del producto final y obteniendo mayores beneficios, esto aplicado al campo televisivo es una de las principales técnicas de los creadores de formatos y cadenas de televisión para atraer y fidelizar a sus espectadores. Y es aquí donde los canales tradicionales de televisión en abierto tienen más problemas puesto que la fórmula de ingresos que tienen, principalmente a través del cobro de los espacios publicitarios en emisión lineal, les dificulta muchísimo el rentabilizar el prestigio que les da sus contenidos en distribución o consumo de OTT, o bien no son significativos de momento. Mientras que las OTT, y los canales de pago, la economía de la experiencia desde un primer momento siempre les ha resultado fácilmente traducible en ingresos o beneficios a modo de suscripción 
mensual, convirtiendo a sus espectadores y usuarios en abonados y totalmente fidelizados.

Este cambio profundo en el aspecto de la tecnología y dispositivos, que ha permitido disfrutar de contenidos audiovisuales, también ha sido acompañado por una redefinición de los formatos, que deben cumplir unos requisitos de una audiencia cada vez más particular, redefiniendo estos contenidos en términos de espacialidad y temporalidad (Innocenti, 2018).

Dichos cambios principalmente se han visto en los formatos de ficción, donde el espectador se hace partícipe de los mismos, e incluso también creador de historias relacionadas con las tramas, gracias a las narrativas transmedia. De esta manera, se crea un valor de marca y una mayor fidelidad por parte del espectador como ya se ha comentado. Según Scolari (2013), una de las cosas más importantes en la ficción transmedia es que los personajes o las tramas caigan en manos de los consumidores y ellos las sigan expandiendo de un medio a otro.

Este Ecosistema televisivo híbrido hace que lo que antes se denominara canal o cadena de televisión, hoy en día se le denomine operador audiovisual, puesto que son múltiples las ventanas y formas de hacer llegar al consumidor sus productos mediáticos, ya sean formatos o publicidad. Este nuevo entorno rompió desde hace tiempo las barreras de la comunicación unidireccional, pasando a la bidireccional en múltiples ventanas. Aun así, la ventana principal para los operadores audiovisuales tradicionales, es decir las cadenas de televisión, sigue siendo el monitor del salón, la televisión.

\section{Diferencias entre TVE y la RAI}

Las emisiones de los dos grupos televisivos públicos nacionales sólo distan de 2 años de diferencia. La RAI empezó en pruebas en 1952, pero sus primeras emisiones regulares comenzaron el 3 de enero de 1954 (Tonello, 2006). Y el 28 de octubre de 1956 TVE comenzaba sus emisiones regulares (Palacio, 2001). Las dos corporaciones siguieron caminos programáticamente similares con la excepción de las diferencias causadas por los distintos entornos políticos y económicos de ambos países. La competencia a los canales públicos de la RAI y TVE se produjo de igual manera en los años ochenta: en Italia con el nacimiento de las privadas del "imperio Berlusconi” y en España con 
las públicas autonómicas en Euskadi y Cataluña, y posteriormente, a finales de la década, con Canal Sur, Telemadrid y Canal Nou; y en los noventa con el nacimiento de las cadenas privadas de Mediaset y Antena 3 en abierto.

Esta llegada de las cadenas privadas es lo que realmente, hasta el día de hoy, marcará la diferencia en unas corporaciones públicas similares pero muy diferentes. Las dos cadenas públicas son objeto habitualmente de críticas de estar politizadas, en algunos momentos en mayor medida, y en otros con una menor repercusión. Durante más de sesenta años de historia de la RAI y TVE han ido llevando caminos similares, pero poco a poco se han ido distanciando, y es sobre todo en los últimos años donde más notable se ha hecho la diferencia. Así este estudio se quiere centrar en los aspectos más actuales, más que en una revisión histórica de los dos modelos de televisión pública.

Por ello hay que remarcar la diferencia posiblemente más grande, y es el posicionamiento en cuanto a resultados de audiencia se refiere y número de canales. La RAI tiene una posición dominante en el número de espectadores frente a sus rivales privados: tres de los cinco canales más vistos en Italia pertenecen al Ente público (RAI 1, RAI 2, RAI 3), siendo la primera, tercera y cuarta opción habitualmente; mientras que en España solo La 1 de TVE está entre los cinco canales más vistos, y en los últimos años en tercera posición. A pesar de que las audiencias en ambos países son muy tradicionalistas, puesto que hay cierta preferencia por los productos nacionales (principalmente en series) o las adaptaciones internacionales con clara identidad propia nacional (en el caso de los formatos de entretenimiento), a la hora de posicionar los productos audiovisuales en sus canales, el resultado ha sido muy diverso. La RAI goza de buena salud y posee tres canales generalistas líderes (dos de un ámbito geográfico más nacional y un tercero con desconexiones territoriales), además de canales temáticos de cine (RAI Movie), series (RAI 4), uno más cultural y variado (RAI 5), otro de noticias veinticuatro horas (RAI News), uno Premium con una mezcla del contenido más destacado (RAI Premium), dos de contenido infantil (RAI Yoyo y RAI Gulp), uno cultural de historia (RAI Storia), otro formativo (RAI Scola), y dos últimos de deportes con prácticamente el mismo contenido, pero uno en HD (RAI Sport y RAI Sport HD). En 
total, el grupo RAI posee 14 canales en abierto, lo que indica el potencial de la televisión pública italiana.

Por su parte, TVE en cambio solo emite en abierto casi un tercio de la oferta de su análogo italiano: La 1, canal generalista; La 2 canal cultural y formativo; Clan como oferta infantil; Teledeporte como oferta deportiva; Canal 24 horas para informativos; y TVE HD que vendría a ser la oferta de La 1 pero en HD. No se cuenta TVE Internacional ni la nueva oferta programática de +24 al no emitir en abierto en TDT. Por lo que aquí ya se puede ver la primera gran diferencia, una oferta más amplia, fragmentada e incluso más cultural en el caso italiano que en el español. Este número de canales tiene un coste, y por ello hay una diferencia sustancial en cuanto al presupuesto de una corporación y otra. La RAI tiene un presupuesto anual de entre los dos mil quinientos y los dos mil ochocientos millones de euros, dependiendo del ejercicio anual (RAI, 2018), mientras que RTVE está algo por debajo de los mil millones de euros (sin contar el patrimonio propio) (RTVE, 2018).

En cuanto al sistema de sostenibilidad económica también hay diferencias importantes. Televisión Española posee un modelo de ingreso por dos vías principales y otras secundarias menores. Las principales son la asignación directa del estado y la compensación económica por partes de los operadores de telecomunicaciones y del resto de operadores televisivos en concepto o contraprestación al no tener publicidad, además de otras fórmulas de ingresos minoritarios en comparación con las anteriores como son retribuciones de cánones, patrocinios, bienes, etc... Hay que destacar que el modelo de RTVE actual es un intento programático al de la BBC, ya que quitó la publicidad convencional de su parrilla, lo que ha llevado a que la principal fuente de ingresos de la Corporación se vea afectada seriamente, puesto que en su lugar depende claramente del resto de operadores para obtener un presupuesto ciertamente escaso. En el caso contrario está la RAI, que ya sea a través de la financiación directa a través de un canon o impuesto directo a los ciudadanos (actualmente incluido en el recibo de la luz, de unos $100 €$ al año (RAI, 2018)), o bien por los ingresos publicitarios, posee un presupuesto mayor y unas cuentas más saneadas que el modelo español.

El debate de publicidad sí o no ya se ha tenido sumamente en España, si bien es cierto que el hecho de que las Corporaciones públicas tengan 
publicidad es muy discutible como argumentan las cadenas privadas (por la doble financiación estatal y privada, pero que sigue existiendo ciertas formas publicitarias con el actual modelo), y los dos grupos privados principales han aumentado considerablemente sus ingresos al poder controlar, y repartirse entre las dos empresas privadas, más del 80\% del "pastel" publicitario televisivo nacional. El principal problema que tiene el modelo financiero de RTVE es que es sumamente dependiente de factores externos y no de sus propios aciertos. El hecho de que la Corporación sea financiada mayoritariamente por el sector privado de telecomunicaciones $y$ operadores televisivos $\mathrm{O}$ audiovisuales, puede compararse al símil de poner "al zorro a vigilar las gallinas". A largo plazo posiblemente sea necesario una reestructuración del modelo de financiación de RTVE, si bien es cierto que la mala percepción en España de la corporación pública imposibilita en gran medida efectuar a corto plazo una aproximación del modelo británico e italiano de imponer un canon directo a los ciudadanos, sumándose a que como ha pasado en Italia, el peligro de una evasión sobre este impuesto es muy elevado, en este país, por ejemplo, han tenido que modificar la fórmula de pago para reducir el porcentaje de impagos, que llegaba a suponer alrededor del 30\% del presupuesto de la RAI de impago (Cucco, 2017), por lo que se optó por incluirlo en el recibo de la luz.

La oferta programática también resulta muy dispar en ambos casos. En esta investigación ha resultado muy dificultoso realizar una correcta comparación entre ambos objetos de estudio centrados en las corporaciones, ya que poseen las siguientes grandes diferencias:

- La multitud de canales que posee la RAI en abierto como canales generalistas, por lo que se centrará el análisis en el canal RAI1, que sería el equiparable más cercano por importancia a La1. La RAI, al poseer varios canales generalistas y otros temáticos de ficción, utiliza un modelo programático holandés o alemán entre sus marcas (Contreras y Palacio, 2003) es decir, entre sus cadenas buscan la alternancia de diferentes tipos de productos audiovisuales y de potencial (en cuanto a número de espectadores) para no competir entre los propios canales del grupo. 
- Los distintos ritmos sociales que diferencia a ambos países, ya que en Italia los horarios son una hora u hora y media antes que en España.

- Las duraciones de los programas son muy diferentes, ya que en Italia la duración de los formatos, y sobre todo en prime time, siguen el modelo internacional (mayoría de países de Europa y Norteamerica) de algo menos de una hora, mientras que en España la tendencia es a que un solo programa ocupe todo el prime time hasta incluso finalizar el late night, de hecho la mayoría de los programas en las parrillas italianas a cualquier hora del día no suelen superar los 55 minutos de duración, y los informativos o "Telegiornale" rara vez tienen una duración superior a los 30 minutos; incluso en la RAI, principalmente, suelen existir varios resúmenes informativos cada un par de horas de cinco minutos de duración, además de los tradicionales informativos de media hora en los pases matinales, mediodía y noche.

- Otra cuestión diferencial que se puede observar si se entra en el detalle de los contenidos que emite la RAI y RTVE en sus principales canales generalistas es la longevidad de los formatos italianos, es decir, al igual que en La1 se puede observar programas como "Informe Semanal" con más de 40 años de emisión continuada, en la RAI existen un mayor número de contenidos o programas de distintos géneros con longevidades similares o mayores en la actual parrilla, fundamentalmente consolidados por unos espectadores algo más tradicionalistas que los ibéricos.

Esto da como resultado un marco de comparativo irregular, por lo que se ha optado a identificar los géneros de los contenidos que más tiempo ocupan en parrilla divididos en mañana, tarde, noche solo entre los dos principales canales públicos. A continuación, se puede observar una tabla (Tabla 2) con la distribución semanal de contenidos principales en el mes de mayo de 2018.

Como se puede observar en la Tabla 2, en las mañanas, tanto la televisión pública italiana como la española predomina principalmente la información o servicios informativos, con dos diferencias: una es la 
duración de los contenidos, que como se ha descrito antes en España suelen ocupar más tiempo en parrilla; y la otra sería el segundo género predominante en las mañanas de lunes a viernes, en el cual la RAI1 prefiere emitir programas culinarios o de cocina, mientras que La1 opta por magazine de actualidad donde cabe casi de todo. Sin embargo, los fines de semana es muy diferente, la RAI apuesta por una variedad de magazines matinales para ocupar la mañana, mientras que TVE en La1 opta por la redifusión de contenidos potentes del prime time con algunos contenidos de infoentretenimiento que lo complementan, algo que en tiempos de la televisión a la carta puede verse como un error pero que no le da malos resultados de audiencia y sirve para ahorra costes.

Tabla 2. Comparativa de géneros programáticos en RAI y La1 de mayo de 2018

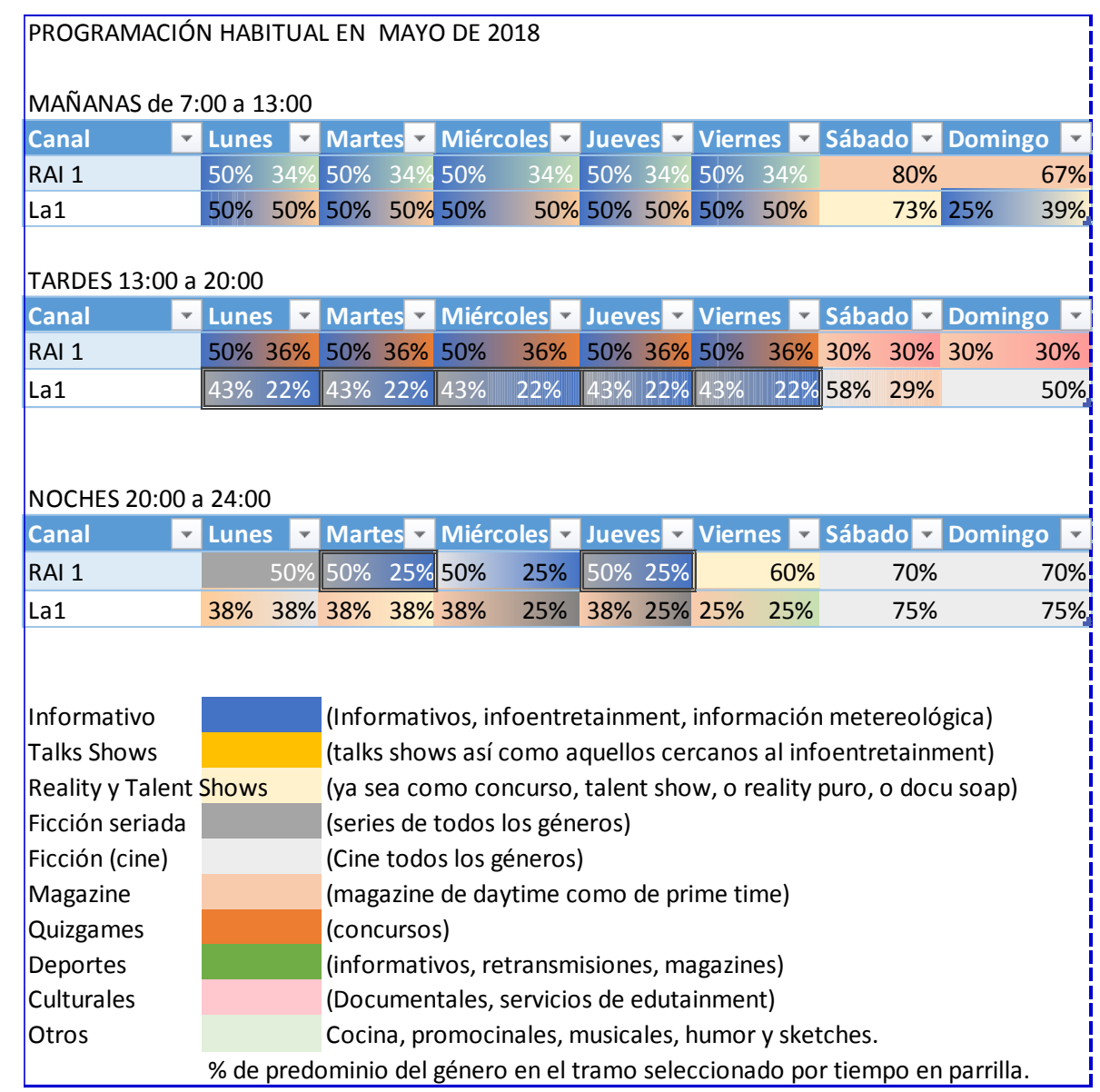

Fuente: Elaboración propia

Las tardes son muy diferentes entre los dos principales canales públicos nacionales: mientras que en Italia hay un predominio de la información 
complementada por los quizgames, en La1 se opta por la ficción seriada que tan buenos resultados le dio en el pasado, aunque no tanto en los momentos presentes. Las tardes de los fines de semana la apuesta de TVE es clara por el cine (principalmente tv movies), mientras que la RAI1 opta más por la emisión de magacines y programación cultural. Las noches, además de los propios servicios informativos en ambos países, con las diferentes duraciones mencionadas anteriormente, los programas estrellas suelen coincidir, ya que cinco de los siete días emiten ficción en ambos canales. En cambio, la RAI1 emite dos días seguidos una misma serie (capítulos diferentes) en prime time, algo poco habitual en la programación española si exceptuamos el access a prime time, donde las principales cadenas generalistas en España suelen posicionar un magazine como pilar programático después de los informativos.

Esta comparativa sobre las coincidencias y diferencias programáticas de las dos principales marcas de la televisión pública están supeditadas, como se ha mencionado antes, a la gran diferencia estructural y de diversificación de oferta de canales dentro de los dos grupos. Asimismo, hay que mencionar que tanto la audiencia como oferta total de la DT'T o TDT (Televisión Digital Terrestre) en Italia está mucho más fragmentada que en España.

Los informativos son un pilar programático en ambos canales de televisión públicos, y por regla general en todos los canales públicos sea cual sea su ámbito de cobertura o nacionalidad. En cambio, la estructura, duración y los contenidos son muy diferentes entre los Telediarios de TVE y los Telegiornali de la RAI. Es habitual que en Italia los informativos no duren más de treinta minutos, y dependiendo del canal incluso menos. En cambio, en España, y en especial los informativos de La1, suelen llegar casi a la hora de duración, e incluso superarla en muchos casos. Esta diferencia se debe principalmente a varias razones:

- Menos piezas informativas en los informativos de la RAI1, RAI2, y RAI3. Aunque lo mismo sucede en los otros canales privados, sí es cierto que la RAI, al poseer tres canales generalistas (RAI3 más orientado a la información más cercana o regional), y un canal veinticuatro horas de noticias, combinan las distintas noticias que dan en cada uno de los canales. Es decir, cada canal 
(RAI1, RAI2, RAI3), en sus principales "Telegiornali" comparten las tres o cuatro principales noticias del día, pero después cada informativo está orientado hacia un tipo de información algo distinta, además de la combinación programática de horas, pues cada uno empieza cuando acaba el otro. En el caso de RAI1, es la información nacional, internacional y económica la que suele primar más que en los otros canales de la televisión pública italiana. Sin embargo, los Telediarios de La1 deben aglutinar todas las piezas o informaciones relevantes del día al no poseer otros canales (salvo el canal 24 horas), donde pueda ofrecer informativos emitidos seguidos. Se excluyen el caso de La2 dada la gran diferencia horaria respecto al Telediario de La1. Como se ha comentado, en Italia van seguidos en los distintos canales (cuando acaba uno empieza el del otro canal), mientras que entre La1 y La2 en la noche pasan más de tres horas entre ambos. Bien es cierto que, si se habla de distintas piezas el caso de La1 y La2 es similar al italiano, pero esa diferencia horaria rompe la posibilidad de alternancia informativa como tal, sino que es más por tipología de canal y target.

- Otra gran diferencia es la escasez de piezas deportivas dentro de los informativos o Telegiornali de la RAI1. Salvo excepciones no suele existir más de un par de piezas de deportes o resúmenes de la jornada de la Serie A (la Primera División de fútbol italiana), y al igual que en España, casi siempre de fútbol. En cambio, en los Telediarios suele destinarse casi un tercio de la duración del informativo al bloque deportivo.

- Pero un espacio que destaca generalmente en los informativos italianos de la televisión pública es el bloque de cultura, en todos los informativos y de manera alternada es muy habitual encontrar piezas sobre cine, literatura, obras de teatro, exposiciones, así como entrevistas a profesionales del mundo de la cultura. Esto es un elemento diferenciador respecto a los Telediarios de La1, que en cuanto a tiempo en pantalla y volumen este tipo de noticias no resulta tan relevante. 
- Por último, es normal, sobre todo los fines de semana, encontrar micro-resúmenes informativos de duraciones inferiores a los 5 minutos cada dos o tres horas. Una estrategia no tan habitual en cadenas generalistas privadas en abierto en Europa, pero sí es cierto que está más estandarizado en algunos operadores públicos.

\section{Convivencia o supervivencia}

Los paralelismos o analogías existentes entre los dos modelos de radiotelevisiones públicas se ven condicionado también por el entorno audiovisual que les rodea, y que se ha mencionado brevemente anteriormente, pero llegados a este punto se puede establecer claramente dos diferencias con el momento actual que viven las dos corporaciones y que resulta totalmente dispar a pesar de las similitudes existentes. La RAI1 y el grupo público de la televisión italiana en general está inmerso en un modelo de "convivencia" en el actual panorama audiovisual italiano, tanto en la ventana programática lineal como en relación a las ofertas audiovisuales de OT'T y pago. RTVE por su parte, en cambio está sumergido en un momento de "supervivencia", dado que tiene una fragilidad presupuestaria, de credibilidad, de audiencia, y de posición frente a la competencia, que le lleva a que su objetivo esté más orientado a no perder, que a poder competir por liderar el mercado audiovisual. La RAI mantiene la preferencia de los italianos como primera opción televisiva claramente porque, aunque existe una fragmentación de canales y de audiencia mayor que en otros países, solo un grupo realmente compite al mismo nivel (de audiencia y económico), Mediaset. Mientras que, en España la fragmentación es menor, es decir hay una mayor diferencia de audiencia y presupuesto entre los principales canales y el resto, pero en cambio son tres los grupos televisivos que hacen una competencia considerable, y que en dos de los tres superan a la Corporación pública en audiencia. Estos grupos son Mediaset (al igual que en Italia), Atresmedia, y el tercer grupo correspondería a los canales pertenecientes a la FORTA. Los canales autonómicos son en España un factor que debilita en términos de audiencia a la televisión nacional pública si se compara con el caso italiano, principalmente porque esta 
labor la realiza RAI3, que se posiciona entre los canales más vistos de Italia, mientras que en España es un maremágnum de distintos canales públicos autonómicos independientes de la Corporación nacional (pero con casi los mismos problemas a mayor o menor escala) que copan audiencias territoriales restando principalmente espectadores a Radio Televisión Española. Esto es debido a la naturaleza de sus contenidos e identidad, que imitan el modelo generalista nacional de La 1, pero que sirve para fomentar identidad cultural, la información de proximidad y la lengua propia de cada región (las que tienen).

En todo caso, aunque TVE esté viviendo un momento de supervivencia, la mayoría de los profesionales comparten la idea y perspectiva que en estos últimos años La 1 ha tocado suelo en cuanto audiencia se refiere, por lo que solo debería crecer en share y número de espectadores con poco que consiga volver a persuadir a la audiencia. Hay que recordar que según los datos de Kantar Media, La 1, ha pasado de dominar durante tres temporadas seguidas la cuota de pantalla hasta 2011 con un 14,5 a llegar a marcar su mínimo histórico anual en 2015 con un 9,8, estando en el último recuento anual (2017) en un 10,4 (Barlovento Comunicación, 2018). Esta bajada de audiencia es paralela o directamente correlacionada a la pérdida de credibilidad y el aumento de la percepción de la politización del medio público, estando situado como uno de los medios menos crébles y con peor valoración por parte de los ciudadanos entre las distintas Corporaciones públicas del oeste de Europa (Pew Research, 2018). Asimismo, la Corporación de Radio Televisión Española ya ha vivido anteriormente situaciones similares en las décadas anteriores, y ha sabido rehacerse y volver a recuperar el liderazgo en audiencias, credibilidad y prestigio internacional. Esta mala percepción suele ser compartida por los ciudadanos de los países mediterráneos sobre sus medios públicos, la diferencia es que, a pesar que la crítica tradicional sobre la credibilidad, el consumo de estos medios como el caso de la RAI es claramente superior y mayoritario por parte de los espectadores, mientras la percepción sobre la imparcialidad en este sentido es considerada similar con respecto a España.

La 1, y en general la industria audiovisual y de la televisión española (tanto productores y operadores), tienen una fortaleza que sin duda la RAI no puede tener de forma natural, y es el mercado hispanohablante como potenciales espectadores. La RAI y el sistema televisivo italiano, 
a pesar de contar un presupuesto y una economía mucho mayor que la española en este sentido (por ejemplo: la RAI cuenta como se ha dicho antes con casi el triple de presupuesto y el doble de trabajadores que RTVE), no comparte idioma con un mercado que aglutina a más de 500 millones de personas en todo el mundo. Este potencial que posee el mercado televisivo español debe ser aprovechado no solo por productores (como es el caso de multitud de título de la ficción española que está triunfando por todo el mundo), sino que la Corporación pública debe convertirse en un referente informativo y televisual predominante en lengua española o castellana, como así lo es $\mathrm{BBC}$ en la lengua anglosajona o CCTV en chino. Para ello, lógicamente hay que empezar mejorando en el propio país, puesto que la publicidad que llega al exterior desde España del propio canal no ayuda a conseguir este referente.

\section{Conclusiones}

La RAI1 y La 1, tienen muchos aspectos en común, y sobre todo comparten un entorno televisivo híbrido donde las OTT, las plataformas de pago, y los competidores privados no ponen fácil la convivencia o supervivencia de estos canales públicos. Los espectadores en ambos países tienen gustos similares por los mismos formatos y, teniendo en cuenta los distintos ritmos sociales y laborales, es escasa la diferencia horaria de las principales franjas diarias de las parrillas televisivas, siendo la italiana alrededor de una hora y media más adelantada que la parrilla española.

Todas las coincidencias que se han podido ver anteriormente pueden suscribirse como una analogía de ambos sistemas televisivos, en cambio los dos principales canales de sus respectivos operadores públicos distan mucho de parecerse o vivir situaciones similares. Para empezar Radio Televisión Española, y La 1 en concreto, tienen unas virtudes como son la posibilidad de internacionalización, la capacidad de reconstruirse una y otra vez, adaptarse, ser precursor en innovación (como ha demostrado con el "Botón rojo", playz, y otros tantos proyectos de innovación que se desarrollan en la más absoluta discreción en la Corporación), e historia donde pueda mirarse y reconocerse respecto a sus rivales. 
La televisión pública española puede ser un gran referente si se corrigen los aspectos más negativos de la Corporación, pero se debe mirar fuera con una visión más amplia a la hora de abordar el modelo tanto programático como estructural de la Radio Televisión Española. Siempre se dice y se compara a RTVE con la BBC, cayendo en continuos errores que hacen imposible la transformación estructural del medio público español en el británico a corto y medio plazo (como puede ser un presupuesto seis veces superior, una plantilla cuatro veces mayor, o simplemente la estructura administrativa y presupuestaria independiente del Gobierno y del Parlamento (El País, 2018)). Por ello, es necesario ampliar la mirada y acertar en lo que funciona en los medios públicos de otros países, sobre todo aquellos a los que más nos parecemos televisivamente, y adaptarlo al modelo actual en España. La RAI en este sentido tiene una serie de aciertos estructurales y programáticos de una mayor facilidad de adaptación al modelo español que otros canales públicos de Europa, como son los siguientes factores:

- Convertir la tradición en fuerza. La RAI es sinónimo de marca Italia o made in Italy, son muchas las voces críticas nacionales con esta institución, pero al final la televisión pública domina claramente los índices de audiencia. Han sabido crear una identidad de canal a lo largo de los años y establecer un lazo de unión con el espectador que sigue eligiendo a este canal como su principal fuente de información y entretenimiento.

- La información y la cultura como ejes programáticos. La RAI tanto entre diario como sobre todo los fines de semana en daytime, dedica muchas más horas a los programas culturales e informativos que la televisión española. Los informativos dedican dentro de sus "Telegiornale" (Telediarios) espacios ciertamente amplios a la cultura (literatura, cine, música, exposiciones, etc...). Además, programáticamente, no resulta extraño ver bastantes reportajes y programas culturales dentro del primer canal.

- La duración más corta de los programas es clave para favorecer su consumo. En Italia el standard de 45-50 minutos de duración de los contenidos de prime time, como en la mayoría de los países. 
Mientras en RTVE, y sobre todo en la franja más importante del día, suelen alargar los contenidos de forma exagerada hasta llegar a las dos horas la ficción seriada, e incluso más de las tres horas algunos formatos de entretenimiento. Véase por ejemplo el caso de Masterchef, donde en casi todo el mundo dura unos 50-55 minutos, mientras en España llega de media a más de tres horas de duración. Es cierto que, programáticamente, alargar los contenidos facilita la labor del programador y todos los técnicos derivados de este control, y si el formato funciona, asegura tener más audiencia durante más tiempo. Pero lo que no es razonable como servicio público es alargar los formatos tanto tiempo en perjuicio del espectador, ni con intereses de audiencias. Además, los programas de menor duración facilitan las "segundas vidas" de estos formatos (tanto de ficción como de entretenimiento) en su forma de consumo "bajo demanda" o "a la carta".

- Aprovechamiento del entorno híbrido. La RAI es un canal que en la televisión tradicional o lineal tiene una apariencia "vieja" o tradicional. Desde su logo hasta algunos de sus decorados, textura de imagen, o forma narrativa de sus contenidos, están orientados a un público más maduro o tradicional. En cambio, en internet y sus aplicaciones ha sabido adaptar su imagen a una forma mucho más moderna y dinámica. Desde su diseño gráfico a sus contenidos, dentro de su propia marca se puede hablar de dos lenguajes diferentes: uno tradicional y otro moderno, dependiendo la ventana desde donde se consuma. En cambio, RTVE tiene un aspecto más moderno en general, con contenidos a veces ambiguos o para todos los públicos en su forma lineal (véase por ejemplo la última edición de Operación Triunfo 2017). Pero al final un único lenguaje dentro de su propia marca indistintamente la ventana desde la cual se consuma, y lo cual provoca que, en un entorno híbrido donde el espectador digital demanda una personalización de los contenidos, no funcione todo lo bien que debiera (excepción de Playz).

Al final la RAI y TVE comparten un espacio televisivo similar en sus países, una cercanía cultural y una naturaleza común, por lo que ambas Corporaciones podrían imitar modelos programáticos y funcionales una de la otra, mejorando sustancialmente en aquellos aspectos que 
pueden flaquear. En este ecosistema híbrido televisivo se hace todavía más necesarios que nunca unos medios públicos audiovisuales fiables y fuertes, donde mantengan la información y la cultura a los usuarios en su ámbito de distribución.

\section{Referencias bibliográficas}

Brembilla, P. (2018). "Dinamiche competitive ed evolutive: le pratiche dell'industria". Ecosistemi narrativi. Dal fumetto alle serie Tv (pp. 147-161). Roma: Carocci editore.

Contreras, J. M., Palacio, M. (2003). La programación en televisión. Madrid: Síntesis.

Cucco, M. (2017). "La economia del broadcasting:la filera e il mercato". La televisione: modelli teorici e percorsi d'analisis (pp. 5164). Roma: Carocci editore.

De Pascalis, I. A., y Pescatore, G. (2018). "Dalle narrazioni estese agli ecosistemi narrativi". Ecosistemi narrativi. Dal fumetto alle serie Tv (pp. 19-30). Roma: Carocci editore.

Pine, B. J., Pine, J., \& Gilmore, J. H. (1999). The experience economy: work is theatre \& every business a stage. Harvard: Harvard Business Press.

Innocenti, V. (2018). "La convergenza e divergenza negli ecosistemi narrativi". Ecosistemi narrativi. Dal fumetto alle serie Tv (pp. 213227). Roma: Carocci editore.

Palacio, M. (2001). Historia de la televisión en España. Barcelona: Gedisa.

Pavani, G. (2015). "El régimen de los medios de comunicación en Italia. El sistema de radio y televisión: ¿una anomalía en el contexto comparado?" Teoría y Realidad Constitucional, núm. 36, pp. 459-496. Madrid: UNED.

Pew Research. (2018). Fact sheets: news media and political attitudes in Western Europe. Recuperado de http://www.pewglobal.org/fact-sheet/news-media-andpolitical-attitudes-in-the-united-kingdom/ 
RAE. (2001). Diccionario de la lengua española (22.a ed.). Madrid: Real Academia Española.

Rosati, L. (2018). "Ecosistemi ed economía dell'esperienza". Ecosistemi narrativi. Dal fumetto alle serie Tv (pp. 73-92). Roma: Carocci editore.

Saló, G. (2003). ¿Qué eso del formato?. Madrid: Gedisa.

Santana Leitner, A. (2013). Fundamentos para la investigación social. Madrid: alianza Editorial.

Scaglioni, M. (2011). La tv dopo la tv. Il decennio che ha cambiato la televisione: scenario, offerta, pubblico. Milán: Editorial Vita e Pensiero.

Scolari, C.A. (2013). Narrativas transmedia: Cuando todos los medios cuentan. Bilbao: Deusto.

Toffler, A. (1980). La tercera ola. Barcelona: Plaza y Janes.

Tonello, F. (2006). "Dall'Italia delle mondine a quella delle veline". Televisione ieri e oggi: Studi e analisi sul caso italiano (pp. 156-190). Roma: Editoriale Marsilio.

\section{Otros documentos}

Barlovento Comunicación. (2018). Informe anual televisivo 2017. Recuperado de https://www.barloventocomunicacion.es/audienciasanuales/analisis-televisivo-2017/

Ericsson ConsumerLab. (2018). Tv and Media 2017. Recuperado de https://www.ericsson.com/en/trends-andinsights/consumerlab/consumer-insights/reports/tv-andmedia-2017

Peinado, F., Alameda, D. (2018, Jun. 29). ¿Qué separa a RTVE de la BBC? El País. Recuperado de https://elpais.com/politica/2018/06/28/actualidad/153018 6579_036259.html 
RAI. (2018). Relazioni e balanci al 31 dicembre 2017. Recuperado de http://biblioteca.uem.es/files/assets/0000/2964/altres_a201 6_guia_elaborar_citas.pdf

RAI. (2018). Canone RAI. Recuperado de http://www.canone.rai.it/Ordinari/ilCanoneOrdinari.aspx\#c anoneEuropa

RTVE. (2018). Cuentas Anuales e Informe de Gestión correspondientes al ejercicio anual terminado el 31 de diciembre de 2017. Recuperado de http://www.rtve.es/contenidos/corporacion/2017_Cuentas _anuales_CRTVE_e_informe_de_gestion.pdf 


\title{
Políticas y estrategias de transparencia para las radiotelevisiones públicas europeas
}

\author{
Iván Puentes-Rivera \\ Universidade de Santiago de Compostela \\ Paulo Carlos López-López \\ Pontificia Universidad Católica del Ecuador Sede Ibarra
}

PARA CITAR: Puentes-Rivera, I. y López-López, P.C. (2018). Políticas y estrategias de transparencia para las radiotelevisiones públicas europeas. En Rodríguez-Castro, M., Pérez-Seijo, S. y Campos-Freire, F. (Eds.). La TV Pública en Europa: Innovación, Retos y Tendencias (175-191). Cuadernos Artesanos de Comunicación, cac 146. La Laguna (Tenerife): Latina. DOI: 10.4185/cac146.

\section{Resumen}

La transparencia en las instituciones públicas, además de ser una obligación legal en determinados aspectos, es un deber moral con la ciudadanía, que confía en los representantes políticos para gestionar adecuadamente su país, incluidos los recursos que, vía impuestos, administran dichas instituciones; y es, también, un factor diferencial, un elemento de valor añadido que aporta reputación y prestigio a la administración que apuesta decididamente por ella. Valores que se traducen en confianza hacia esa institución y, lo más importante, en confianza en el sistema político, profundizando así en la participación ciudadana, en su capacidad de decisión, en la configuración de una opinión pública mejor formada y, en definitiva, en la mejora de la estabilidad y la calidad democrática. 
En este contexto, el presente trabajo reflexiona sobre la importancia de aplicar este compromiso con la transparencia a los medios de comunicación de titularidad pública, específicamente a la radio y la televisión, en la medida en que, además de ser sostenidas en parte o exclusivamente con recursos públicos, de la ciudadanía, estos operadores tienen en el seno de la Unión Europea la consideración de servicio público, vinculado incluso, a través de las diferentes constituciones nacionales, al derecho fundamental a comunicar o recibir libremente información veraz. Con este fin, se realiza un breve análisis comparativo de las políticas de transparencia en la UE y se proponen elementos a valorar en la política de comunicación y empresa de los medios públicos, susceptibles de convertirse en indicadores que permitan valorar su nivel de compromiso con la transparencia.

Palabras clave: transparencia, medios de comunicación públicos, políticas de comunicación, análisis comparativo, indicadores de transparencia.

\section{Introducción}

El fulgurante desarrollo de las tecnologías de la información y del conocimiento ha permitido que todo tipo de organizaciones, públicas y privadas, dispongan de canales más efectivos para poder difundir sus procesos de rendición de cuentas, a la vez que ha dispuesto a la ciudadanía herramientas útiles para poder participar en el espacio público de una forma más activa. En esta misma línea, los medios de comunicación -muy especialmente el servicio público audiovisual-, han asumido la responsabilidad, en estos últimos diez de años, de mejorar sus respectivos procesos de producción de la información, gestión económica o de su relación con la audiencia desde una perspectiva individual (acceso a información pública, valoración de contenidos) o desde una perspectiva corporativa (relación con grupos de interés). Es decir, transparentar la acción en términos periodísticos, administrativos, gerenciales y presupuestarios.

El concepto de transparencia se relaciona de una forma directa con un modelo de democracia más inclusiva y participativa y permite un proceso de recuperación de legitimidad del servicio público de radio y de televisión que ha vivido momentos de debilidad después de la crisis 
económica. Su significación se ha vuelto una de las prioridades en los diferentes Estados, plasmado en su marco legal, así como en los propios organismos internacionales. Por ello, el acceso libre a la información de la que disponen las organizaciones debe ser comprensible, completa y actual, ya que es la única vía que fomenta el diálogo y un proceso de retroalimentación en la que intervienen las organizaciones, los propios medios de comunicación y la ciudadanía.

Uno de los estudios especiales sobre el derecho de acceso a la información, publicado por la Comisión Interamericana de Derechos Humanos (OEA, 2007), indica que el acceso a la información, en general, es un instrumento de prevención de la corrupción muy poderoso, además de mejorar la calidad de los sistemas democráticos y una herramienta para recuperar la credibilidad de los ciudadanos/as en sus servicios públicos de radio y televisión. Y es que la realidad económica que se ha vivido a nivel europeo y planetario ha provocado una quiebra de confianza entre la ciudadanía y el conjunto de las instituciones, siendo la prioridad la visualización de una gestión pública racional y transparente.

De esta forma, un servicio público de radiotelevisión debe corresponsabilizar a la ciudadanía en términos de toma de decisiones para poner en valor su vocación social y su carácter de herramienta de democratización. Este hecho se torna muy importante en el caso específico del España, con un sistema mediático peculiar y particular por la existencia de un gran entramado público de servicios de radiotelevisión, como son las radios y televisiones autonómicas organizadas casi en su totalidad en torno a la FORTA (Federación de Organismos de Radio y Televisión Autonómicos), además del servicio público de radiodifusión de titularidad estatal. A este modelo de gobernanza multinivel (Azurmendi y Muñoz, 2016), además de los objetivos de accesibilidad, apertura, transparencia, diálogo y pluralismo, se le debe añadir la promoción de la diversidad, riqueza cultural y promoción del plurilingüismo.

\section{Transparencia en las empresas informativas}

La transparencia en las empresas informativas ha evolucionado a lo largo de los años, con diferentes tipologías. En primer lugar, cabe 
destacar el modelo que diferencia tres tipos de transparencia (Heijji, Domingo, Pies, Glowacki, Kus y Baisnée, 2012), a saber: la que se da antes de la publicación (información sobre la empresa), durante la publicación (elaboración de las noticias) y tras la publicación (asunción de responsabilidades). Igualmente, el Internacional Center for Media and the Public Agenda (Redondo y Campos Domínguez, 2016) se centraría en cinco tipos de transparencia: correcciones, propiedad, política de personal, política informativa y procesos de producción y participación; en este contexto, la participación se convierte, pues, en un elemento fundamental. Anteriormente el proceso de retroalimentación que se le otorgaba a la ciudadanía era muy pequeño (en el ámbito analógico, las llamadas cartas al director o buzón de sugerencias), generando en la actualidad auténticos procesos de interacción social con los grupos de interés, construyendo valores sociales, cívicos y políticos de forma conjunta, aprovechando las tecnologías de la información y del conocimiento.

El objetivo último de la participación ciudadana es el de evaluar y reorientar la toma de decisiones de las personas que gestionan la organización o el dinero público. En el caso concreto de las televisiones públicas europeas, adicionalmente, se entiende que deben contribuir a la construcción de una agenda del buen gobierno; además del cumplimiento de lo legalmente exigido en su estado, deben incorporar recomendaciones internacionales de organismos como la Unión Europea de Radiodifusión, la UNESCO o Transparencia Internacional en sus propios códigos de conducta internos. Lo mismo es condición necesaria, que no suficiente, para asegurar la independencia, la fortaleza en la gestión de recursos y la recuperación de la legitimidad en este tipo de servicios.

Por todo ello, los conceptos de transparencia, rendición de cuentas o accountability toman un nuevo significado en la sociedad digital, debiendo los servicios de radio y de televisión de carácter público asumirlo con un imperativo. Esta imagen de buen gobierno o gobierno abierto se convierte en imprescindible en todas las organizaciones y se consigue mediante una secuencia articulada: imperativo legal, voluntad de los consejos de administración, capacidad de la sección correspondiente para llevarlo a cabo y un espacio web que permita hacerlo operativo de manera accesible y comprensible. Por ello, desde 
la perspectiva netamente instrumental, el proceso de rendición de cuentas se adapta a un entorno digital y establece mecanismos de participación.

En los últimos años la participación ciudadana se ha institucionalizado, también en el servicio público de radiodifusión, generando espacios interactivos con la sociedad civil. Por ejemplo, la BBC británica promovió un proceso de discusión a la hora de elaborar el Informe para la Reforma de la Carta de la BBC, que expiraba a finales de 2016, siendo una de las cuestiones que planteaba la necesidad de crear nuevas vías de participación de la audiencia. Este es un ejemplo de un modelo de desarrollo institucional y de fomento de la transparencia, posibilitando a las sociedades el ejercicio de control a partir de la información que generan las organizaciones y los propios medios de comunicación.

La televisión pública, orientada principalmente al servicio público, tal y como indica la UNESCO, hace referencia a las actividades que proporcionan calidad de vida a la ciudadanía en una doble vertiente: en la perspectiva individual, como una herramienta social, participativa y con carácter educativo; desde la perspectiva colectiva, como motor económico, de innovación y de potenciación de la propia industrial cultural.

\section{El contexto europeo de la transparencia}

El papel del servicio audiovisual ha sido desigual dependiendo de la geografía. Así como en Norteamérica su papel ha estado orientado principalmente al mercado y en América Latina con una visión excesivamente gubernamental, al servicio del gobierno de turno, en Europa su importancia siempre ha estado fuera de toda duda, ya que ha permitido y permite la cohesión social, fomentando el pluralismo y mejorando los procesos democráticos.

En la actualidad, la sociedad digital y la consiguiente convergencia mediática han promovido un cambio disruptivo, no tanto en la vocación de servicio público de los propios entes, como en su organización interna, presionada, por una parte, por un mercado cada vez más competitivo y por la otra, por legislaciones más exigentes que promueven otro modelo de gobernanza, más cooperativa y que 
fomentan mecanismos de transparencia, participación y rendición de cuentas. Y es que, al fin y al cabo, la ciudadanía tiene el derecho de saber cómo se gestionan los recursos económicos y colectivos de los servicios públicos de televisión por ser ella misma quien sustenta ese servicio con sus impuestos.

Como en buena parte de los asuntos que conciernen a Europa, también en lo que a la regulación del deber de transparencia de las administraciones públicas se refiere, la disparidad es la norma. Así, la realidad y condicionantes sociales, políticos, jurídicos o de tradición de cada estado se imponen a un deseable marco legal europeo armonizado en la materia. Éste, de existir, debería garantizar los derechos de la ciudadanía europea y su ejercicio efectivo en condiciones de igualdad con independencia del estado en el cual se resida, pero, como queda dicho, ésta es aún una realidad lejana, que ni siquiera se dibuja en el horizonte a medio o largo plazo.

A ello contribuye el hecho, sin duda, de que la Unión Europea carezca de competencias para obligar a los estados miembros a la adopción de medidas concretas sobre transparencia o acceso a la información pública con las que poder armonizar el desarrollo de ese derecho en todo el territorio de la Unión (Ares, 2013, p. 21). La UE tan sólo, y a ello se ha limitado en las últimas décadas, puede regular el acceso a la información y documentación relacionada directamente con ella, particularmente con la Comisión, el Parlamento y el Consejo de la Unión Europea. Así, ya en la década de los 80 una Resolución del Parlamento Europeo de 24 de mayo de 1984 insta al Consejo y a la Comisión a considerar como derecho fundamental de la ciudadanía europea el acceso a la información (Blanes, 2017).

A partir de ahí, en paralelo con el proceso de construcción de la propia Unión Europea, se van dando pasos hacia el reconocimiento de dicho derecho. En 1992 el Tratado de la Unión Europea (TUE) o Tratado de Maastricht, tratado fundacional de la UE, si bien no lo incluye entre su articulado, sí lo incorpora en una de sus declaraciones anexas, la 17, que motivó toda una serie de reglamentos y pasos en años posteriores por parte de las instituciones europeas a fin de regular, al menos fácticamente, el acceso de los ciudadanos europeos a la información de las instituciones comunitarias. Algo más allá fue el Tratado de Ámsterdam, firmado en 1997, pues en el artículo 255 reconoce el 
derecho de los ciudadanos europeos a acceder a los documentos de las instituciones comunitarias antes señaladas, concibiéndolo, así, como "un derecho fundamental autónomo, independiente de la libertad de expresión y del derecho general a recibir información, asociado a la ciudadanía comunitaria", siendo "esencial para considerar a la Comunidad Europea como un Estado democrático” (Blanes, 2017).

Un año más tarde de la firma del Tratado de Ámsterdam, en el año 2000, la Carta de Derechos Fundamentales de la Unión Europea recoge (art. 42) el derecho de acceso a los documentos del Parlamento, la Comisión y el Consejo de la Unión Europea como derecho fundamental de la ciudadanía de la Unión. Esto da pie a la aprobación en 2001 del Reglamento (CE) núm. 1049/2001, del Parlamento Europeo y del Consejo, de 30 de mayo de 2001, relativo al acceso del público a los documentos del Parlamento Europeo, del Consejo y de la Comisión, que desarrolla y hace efectivo el mencionado derecho.

El proyecto de Constitución para Europa (2004), malogrado tras el rechazo en referéndum por parte de algunos estados miembros, consolidaba este derecho, al establecer como derechos y libertades fundamentales de los ciudadanos europeos los recogidos en la Carta de Derechos Fundamentales del año 2000, por tanto, también el de acceso a la información y documentación pública. Finalmente, el Tratado de Lisboa (2007) recoge el espíritu del abandonado proyecto de Constitución Europea e incorpora a su articulado la mencionada Carta, dándole así carácter vinculante y otorgándole (artículo 6) el mismo valor jurídico que a los tratados fundacionales de la Unión (Tratado de la Unión Europea, p. C 83/19). Esto significa que su incumplimiento o las resoluciones de cualquier estado miembro contrarias a lo que en dicho tratado está dispuesto pueden ser objeto de denuncia por parte de los ciudadanos ante la justicia europea (Tribunal de Justicia de la UE en Luxemburgo) y que también los tribunales nacionales deben acogerse a ello a la hora de dictar sus resoluciones.

Adicionalmente, el hecho de que el Tratado de Lisboa obligue a todos los estados miembro a adherirse al Convenio Europeo para la Protección de los Derechos Humanos y de las Libertades Fundamentales, implica también que la vulneración de los derechos y libertades recogidos en la Carta de Derechos Fundamentales de la UE pueda ser recurrida, además, ante el Tribunal Europeo de Derechos 
Humanos de Estrasburgo (Blanes, 2017); al que los ciudadanos europeos podrían acudir, por tanto, además de a la justicia de su estado y al Tribunal de Justicia de la UE, para reclamar el acceso a cualquier tipo de información relacionada con las instituciones europeas o, tal y como recoge la Carta en su artículo 41.2 "el derecho de toda persona a acceder al expediente que le afecte, dentro del respeto de los intereses legítimos de la confidencialidad y del secreto profesional y comercial", vinculando así la transparencia con el "derecho a una buena administración", título de ese artículo 41 (Carta de los Derechos Fundamentales de la Unión Europea, p. 364/18).

En paralelo a que la Unión Europea empezase a actuar sobre este asunto, otra institución del continente, el Consejo de Europa, integrado por 47 países, entre ellos los 28 de la UE, fue la primera que, dentro de su misión de velar por la democracia y los derechos civiles en Europa, inició el camino que llevaría a considerar décadas más tarde la transparencia y el acceso a la información como un derecho básico, también en los medios de comunicación. No en vano, el Consejo de Europa fue el encargado de redactar en 1950 el Convenio Europeo para la Protección de los Derechos Humanos y de las Libertades Fundamentales $(\mathrm{CEDH})$, antes comentado, que ciertamente no recoge de modo expreso el derecho de acceso a la información, pero sí el de libertad de expresión (art. 10), dentro del cual el Tribunal Europeo de Derechos Humanos consideró integrado el primero, a raíz de una sentencia dictada en 2009; mismo año en el que el Consejo ofrece a firma a sus miembros el Convenio número 205, de 18 de junio, sobre el acceso a los documentos oficiales (Ares, 2013).

Pese a la falta de competencias de la UE, antes señalada, para armonizar las normas estatales de transparencia y acceso a la información pública dentro de la Unión, resulta, no obstante, obvio que con la apuesta y defensa hecha en los últimos años, en lo que a las instituciones comunitarias respecta, de ese derecho, aun sin capacidad normativa efectiva, los tratados y la Carta de Derechos de la UE, además de los acuerdos no vinculantes del Consejo de Europa, marcan sin duda, de facto, directrices, tendencias o ejemplos a seguir.

Las mismas contagian a las realidades nacionales y acaban derivando en legislaciones particulares y diversas que afectan de forma directa o indirecta a los servicios públicos de radiotelevisión, pero también con 
un espíritu o finalidad compartida, que es el de incrementar el nivel de transparencia de las administraciones públicas, particularmente del poder ejecutivo, como síntoma de evolución y consolidación democrática y como arma de empoderamiento de la ciudadanía y control efectivo de la corrupción. Una relación entre transparencia y democracia que, entre otras instituciones, ha puesto de relieve el Tribunal de Justicia de la Unión Europea (Lozano, Plaza y Pérez, 2000), al fijar en sus sentencias (SSTG de 14 de octubre de 1999, Bavarian Lager contra Comisión y de 7 de febrero de 2002, Aldo Kuijer contra Consejo) que el derecho de acceso a la información pública contribuye "a reforzar el principio de la democracia y el respeto de los derechos fundamentales".

\subsection{Leyes de transparencia}

Así, 25 de los 28 estados miembros de la UE, todos menos Chipre, Luxemburgo y Malta, poseen a día de hoy leyes de transparencia y/o acceso a la información pública, destinadas todas ellas, con diferente intensidad y mecanismos de cumplimiento diversos, a lograr el objetivo de una mayor rendición de cuentas por parte de los poderes públicos, que redunde en una mayor confianza e implicación de la ciudadanía con sus instituciones y, en definitiva, en una mayor calidad del sistema democrático.

Tabla 1. Leyes nacionales de transparencia en los estados miembros de la UE

\begin{tabular}{|c|c|c|c|}
\hline País & Año & Constitución & Ley en vigor \\
\hline Alemania & 2005 & - & $\begin{array}{l}\text { Ley Federal sobre Libertad de Información, de } 5 \\
\text { de septiembre de } 2005\end{array}$ \\
\hline Austria & 1987 & $\begin{array}{l}\text { Artículo } 20 \\
\text { Constitución de } \\
1929\end{array}$ & $\begin{array}{l}\text { Ley } 286 / 1987 \text {, de } 15 \text { de mayo, de Marco Federal } \\
\text { sobre la Información }\end{array}$ \\
\hline Bélgica & 1994 & $\begin{array}{l}\text { Artículo } 32 \\
\text { Constitución de } \\
1994\end{array}$ & $\begin{array}{l}\text { Ley } 94-1724 \text {, de } 2 \text { de abril de } 1994 \text { y Ley federal } \\
\text { de } 12 \text { de noviembre de } 1997\end{array}$ \\
\hline Bulgaria & 2000 & $\begin{array}{l}\text { Artículo } 41 \\
\text { Constitución de } \\
1999\end{array}$ & $\begin{array}{l}\text { Ley de Acceso a la Información Pública de } 7 \text { de } \\
\text { julio de } 2000\end{array}$ \\
\hline Chipre & - & - & - \\
\hline
\end{tabular}




\begin{tabular}{|c|c|c|c|}
\hline Croacia & 2003 & - & $\begin{array}{l}\text { Ley sobre el Derecho de Acceso a la Información } \\
\text { de } 15 \text { de octubre de } 2003\end{array}$ \\
\hline Dinamarca & 1970 & - & $\begin{array}{l}\text { Ley, } 571 \text { de } 19 \text { de diciembre de } 1985 \text {, de la } \\
\text { Administración Pública y Ley } 572 \text { de } 19 \text { de } \\
\text { diciembre de } 1985 \text {, sobre el Acceso a los Archivos } \\
\text { de la Administración Pública }\end{array}$ \\
\hline Eslovaquia & 2000 & $\begin{array}{l}\text { Artículo } 26 \\
\text { Constitución de } \\
1992\end{array}$ & $\begin{array}{l}\text { Ley } 211 / 00 \text { sobre libre acceso a la información, de } \\
17 \text { de mayo de } 2000\end{array}$ \\
\hline Eslovenia & 2003 & $\begin{array}{l}\text { Artículo } 39 \\
\text { Constitución de } \\
1991\end{array}$ & $\begin{array}{l}\text { Ley sobre Acceso a la Información de Carácter } \\
\text { Público de } 25 \text { de febrero de } 2003\end{array}$ \\
\hline España & 2013 & $\begin{array}{l}\text { Artículo } 105 \\
\text { Constitución de } \\
1978\end{array}$ & $\begin{array}{l}\text { Ley } 19 / 2013 \text {, de } 9 \text { de diciembre, de transparencia, } \\
\text { acceso a la información pública y buen gobierno }\end{array}$ \\
\hline Estonia & 2000 & $\begin{array}{l}\text { Artículo } 44 \\
\text { Constitución de } \\
1992\end{array}$ & $\begin{array}{l}\text { Ley de Información Pública de } 15 \text { de noviembre } \\
\text { de } 2000\end{array}$ \\
\hline Finlandia & 1951 & $\begin{array}{l}\text { Artículo } 12 \\
\text { Constitución de } \\
1999\end{array}$ & $\begin{array}{l}\text { Ley 621/99, sobre Apertura de las Actividades del } \\
\text { Gobierno, de } 21 \text { de mayo de } 1999\end{array}$ \\
\hline Francia & 1978 & - & $\begin{array}{l}\text { Ley } 78-753 \text { de } 17 \text { de julio de } 1978 \text {, Ley } 2000-321 \text { y } \\
\text { Ley } 79-18 \text { sobre consulta de archivos de } 3 \text { de } \\
\text { enero de } 1979\end{array}$ \\
\hline Grecia & 1986 & $\begin{array}{l}\text { Artículos 5A y } 10 \\
\text { Constitución de } \\
1975\end{array}$ & $\begin{array}{l}\text { Ley 2690/1999, del Código de Procedimiento } \\
\text { Administrativo, de } 9 \text { de marzo de } 1999\end{array}$ \\
\hline Hungría & 1992 & $\begin{array}{l}\text { Artículo } 61 \\
\text { Constitución de } \\
1949\end{array}$ & $\begin{array}{l}\text { Ley LXIII sobre Protección de Datos Personales } \\
\text { y Revelación de Datos de Interés Público, de } 27 \\
\text { de octubre de } 1992\end{array}$ \\
\hline Irlanda & 2003 & - & $\begin{array}{l}\text { Ley } 13 \text { de } 21 \text { de abril de } 1997 \text { de Libertad de } \\
\text { Información }\end{array}$ \\
\hline Italia & 1990 & - & $\begin{array}{l}\text { Ley } 241 \text { de } 7 \text { de agosto de } 1990 \text {, de nuevas } \\
\text { normas en el procedimiento administrativo y el } \\
\text { derecho de acceso a los documentos } \\
\text { administrativos }\end{array}$ \\
\hline Letonia & 1998 & - & $\begin{array}{l}\text { Ley de Libertad de Información de } 29 \text { de octubre } \\
\text { de } 1998\end{array}$ \\
\hline Lituania & 1996 & $\begin{array}{l}\text { Artículo } 25 \\
\text { Constitución de } \\
1992\end{array}$ & $\begin{array}{l}\text { Ley 1-1418 sobre Información al Público, de } 2 \text { de } \\
\text { julio de } 1996\end{array}$ \\
\hline Luxemburgo & - & - & - \\
\hline
\end{tabular}




\begin{tabular}{|c|c|c|c|}
\hline Malta & - & - & - \\
\hline Países Bajos & 1978 & $\begin{array}{l}\text { Artículo } 110 \\
\text { Constitución de } \\
1983\end{array}$ & $\begin{array}{l}\text { Ley sobre Acceso Público a la Información del } \\
\text { Gobierno, de } 31 \text { de octubre de } 1991\end{array}$ \\
\hline Polonia & 2001 & $\begin{array}{l}\text { Artículo } 61 \\
\text { Constitución de } \\
1997\end{array}$ & $\begin{array}{l}\text { Ley de Acceso a la Información Pública, de } 6 \text { de } \\
\text { septiembre de } 2001\end{array}$ \\
\hline Portugal & 1993 & $\begin{array}{l}\text { Artículo } 48 \\
\text { Constitución de } \\
1976\end{array}$ & $\begin{array}{l}\text { Ley 65/1993, sobre Acceso a los Documentos } \\
\text { Administrativos, de } 26 \text { de agosto de } 1993\end{array}$ \\
\hline Reino Unido & 2000 & - & $\begin{array}{l}\text { Ley de Acceso a la Información, de } 30 \text { de } \\
\text { noviembre de } 2000\end{array}$ \\
\hline $\begin{array}{l}\text { República } \\
\text { Checa }\end{array}$ & 1999 & $-*$ & $\begin{array}{l}\text { Ley 2/1993, que contiene la Carta de Derechos y } \\
\text { Libertades fundamentales, que posee valor } \\
\text { constitucional* y Ley 106/1999, sobre Libre } \\
\text { Acceso a la Información, de } 11 \text { de mayo de } 1999\end{array}$ \\
\hline Rumanía & 2001 & $\begin{array}{l}\text { Artículo } 31 \\
\text { Constitución de } \\
1991\end{array}$ & Ley 554/2001 sobre Libertad de Información \\
\hline Suecia & 1766 & $-*$ & $\begin{array}{l}\text { Ley de Libertad de Prensa de 1766, que forma } \\
\text { parte de la Constitución* }\end{array}$ \\
\hline
\end{tabular}

Fuente: Elaboración propia a partir de los datos de Ares (2013, pp. 18-19)

\section{Políticas para la mejora de la transparencia en los servicios de radiotelevisión}

El destino de la actividad de la empresa informativa, claramente, está en la sociedad. Los ciudadanos, cada vez más ávidos de calidad informativa dentro del amplio panorama mediático actual, exigen un periodismo responsable que priorice el sentido del deber y se aleje del control oligopólico de la opinión pública facilitado por la tradicional estructura de concentración de los medios tradicionales, aunque también el acceso a la información. Facilitarlo a través de sus páginas web ayuda a incrementar la confianza de la sociedad en estas instituciones y en el gobierno del que dependen. Del mismo modo, mejora la toma de decisiones de la ciudadanía, pudiendo ésta llegar a influir en su modo de actuar. Esta influencia será solo posible si existe una opinión pública robusta, fortalecida por unos medios informativos plurales y transparentes. 
El estudio de la transparencia en las televisiones o en sus respectivas corporaciones es una práctica de reciente aplicación en el ámbito investigativo. Si bien existe una amplia literatura, revisiones comparadas y clasificaciones sobre el nivel de acceso a la información pública de multitud de administraciones, aún no se ha consolidado la auditoría a este tipo de empresas informativas como parte esencial del sistema democrático y como mecanismo de mejora del proceso de diálogo en el ámbito de la Comunicación Política (López-López, Puentes-Rivera y Rúas-Araujo, 2017). Además, en el caso de existir, se ha centrado, por analogía con el resto de entidades y obviando que se trabaja con un bien de servicio público como es la información, en cuestiones institucionales y de gobierno, dejando de lado el control de los procesos de producción de la información. A partir del análisis del contexto europeo, resulta pertinente establecer estrategias concretas orientadas a los siguientes aspectos:

- Marco competencial, organismos y acuerdos: la información sobre la delimitación de competencias y responsabilidad es un elemento importante a la hora de exigir responsabilidades. Identificar quién gestiona los recursos colectivos, a través de qué mecanismos, bajo qué mandato y mediante qué delegación resulta imprescindible para realizar una fiscalización efectiva sobre la actividad ordinaria y extraordinaria de las radios y televisiones, al igual que la publicación de las actas, resoluciones y acuerdos. Igualmente, es importante delimitar las funciones de los diferentes consejos (Administración, Asesor, Redacción, auxiliares).

- Organigramas, estructura y máximos responsables: la representación gráfica de los departamentos de dirección, gestión y de producción de las televisiones es una actividad sencilla, pero que en pocas ocasiones se cumple. Ayuda a la compresión de las estructuras y evita la existencia de duplicidades y despilfarro. Igualmente, es necesario recalcar el proceso de elección del máximo responsable para garantizar la perspectiva de independencia del ente. Se debe realizar hincapié en el proceso de elección del órgano territorial respectivo, de existir.

- Relación con grupos de interés: la relación con los grupos de interés o los colectivos prioritarios debe realizarse en dos fases. 
En primer lugar, se debe disponer de una relación de estos, estableciendo datos sobre las acciones destinadas a fortalecer los vínculos existentes y los propios resultados de los mismos. En segundo término, aprovechando las tecnologías aplicadas, institucionalizar lugares que permitan una interacción directa entre los responsables del medio y los colectivos (espacios privados, instrumentos de valoración de acciones, planes operativos conjuntos, etc.).

- Tratamiento periodístico, mecanismos de independencia y calidad: es necesario dejar claro que una auditoría de información pública no está destinada a evaluar el contenido del medio de comunicación, sino el proceso de producción. De esta forma, además de la publicación de las pautas éticas de comportamiento y tratamiento de la información por parte de los periodistas, es necesario establecer los mecanismos de preservación de su independencia respecto del poder ejecutivo. Los mecanismos de control de la calidad tienen que ser dobles: a través de oleadas de encuestas con su correspondiente informe de acceso público y mediante revisión por pares.

- Accesibilidad de la información económica y laboral: por su propia naturaleza es esta información la más susceptible de, pese a estar teóricamente a disposición de la ciudadanía, resultar incomprensible para el público general, y conviene recordar que el fin último de la transparencia no es la publicación de datos, sino el hallazgo y comprensión de los mismos por quien los busca. Por tanto, en el caso de la información económica y laboral, resulta especialmente importante, además de poner a disposición de quien los quiera consultar los documentos completos de balances, cuentas, presupuesto, informes de gestión, de auditoría... incluir siempre una explicación sencilla de los mismos, apoyándose en gráficos e infografías interactivas, que permitan a un ciudadano medio comprender el significado de esos datos y relacionar unos con otros. Se trata, por tanto, de trabajar un aspecto cualitativo, práctico, de la transparencia que es tan, o incluso más, importante que el cuantitativo, la cantidad de información disponible.

- Igualdad e integración: es obvia la importancia creciente que en la sociedad y en el seno de las organizaciones han adquirido las 
políticas de igualdad y de integración, fundamentalmente las destinadas a garantizar la igualdad de oportunidades entre mujeres y hombres. Por ello, los operadores de televisión deberían ir más allá de la elaboración de planes de igualdad o de garantizar igualdad salarial, cuestiones que hoy ya son básicas. Deben cuidar la presencia paritaria de hombres y mujeres en su plantilla y órganos de dirección, entre los rostros que son imagen de la cadena, entre los colaboradores y expertos invitados de sus diferentes espacios o entre los protagonistas de los contenidos emitidos. Destaca en este sentido, por ejemplo, una iniciativa de France TV, que ha configurado una base de datos pública de expertas en diversos campos a los que los medios puedan recurrir cuando necesiten opiniones cualificadas sobre un determinado asunto.

- Empleo y plantilla de trabajadores: en diferentes análisis efectuados resulta especialmente llamativa la opacidad demostrada por el conjunto de corporaciones en relación con la representación de los trabajadores, pues son éstos, junto con el inventario de bienes y los informes mensuales de ejecución presupuestaria, los aspectos que prácticamente ningún operador cumple. Siendo los trabajadores y sus delegados sindicales una parte importante, imprescindible, de la estructura interna de la organización, resulta especialmente importante cuidar la información relativa a los mismos, aspecto que en varios servicios de radio y televisión se articula mediante un portal de empleo y formación específico, destinado tanto a los profesionales que desean incorporarse a la cadena, como a la información relativa a los propios trabajadores.

- Sostenibilidad: al igual que ocurre con la igualdad, la apuesta por el desarrollo sostenible es hoy también parte imprescindible de la acción de cualquier organismo, más de aquellos que son de titularidad pública, y no sólo como una política más de sus acciones de responsabilidad social corporativa, sino que la sostenibilidad debe impregnar a la corporación, responder a esta filosofía todo su trabajo. Un buen ejemplo es el puesto en marcha por la BBC, informando periódicamente de la reducción de su huella de carbono y desarrollando la aplicación Albert, la primera calculadora de carbono de producción de televisión del mundo, 
que permite reducir la huella de carbono en la producción de todo tipo de contenidos para la BBC y la industria audiovisual del Reino Unido.

Estas estrategias y su respectiva traslación al espacio web de la corporación, deben promover la construcción de indicadores internos y externos para la evaluación de los niveles de transparencia en las radios y televisiones, que deben ser sistemáticas, completas, públicas, reguladas y compartidas entre los todos los países de la UE para armonizar el concepto de ciudanía europea en su sentido más pleno.

\section{Referencias bibliográficas}

\section{Bibliografía científica:}

Ares González, M. V. (2013). "La transparencia en la Unión Europea.

Una visión comparada". Participación educativa, 2(3), 15-23.

Disponible en: https://sede.educacion.gob.es/publiventa/latransparencia-en-la-union-europea-una-visioncomparada/educacion-transparencia-administrativa/16166

Azurmendi, A. y Muñoz, M. (2016). "Participación del público en televisiones públicas autonómicas: una propuesta a partir de la reforma 2016 de la BBC". El profesional de la información, 5, 803-813.

Blanes, M. A. (2017). El acceso a la información pública en la Unión Europea. Disponible en:

https://miguelangelblanes.com/2017/01/24/el-acceso-a-lainformacion-publica-en-la-union-europea/\# ftn1

Heijji Heikkilä, H., Domingo, D., Pies, J., Glowacki, M., Kus, M. y

Baisnée, O. (2012). MediaAccountability Goes Online. A transnational study no emerging practices and innovations (MediaACT Workingpaper). Tampere (Finlandia): Journalism Research and Development Centre y Universidad de Tampere.

López-López, P. C., Puentes-Rivera, I., y Rúas-Araújo, J. (2017).

"Transparencia en televisiones públicas: desarrollo de indicadores y análisis de los casos de España y Chile". Revista 
Latina de Comunicación Social, 72, 253-272. DOI:

https://doi.org/10.4185/RLCS, 72-2017-1164

Lozano Cutanda, B., Plaza Martín, C. y Pérez Carrillo, E. F. (2000).

"La transparencia en el funcionamiento de la Unión Europea.

$\mathrm{El}$ acceso público a los documentos de sus instituciones y

órganos". Revista Vasca de Administración Pública, 56, 349-385.

Disponible en: https://www.euskadi.net/r61-

s20001x/es/t59aWar/t59aMostrarFicheroServlet?t59aIdRevi

$\underline{\text { sta }=2 \& R 01 H N o P o r t a l}=$ true\&t 59 aTipoEjemplar $=\mathrm{R} \& \mathrm{t} 59 \mathrm{aNu}$

$\underline{\mathrm{mEjemplar}=56}$

OEA: Organización de los Estados Americanos (2007). Estudio

Especial sobre el Derecho de Acceso a la Información. Washington,

D.C.: OEA. Disponible en:

http://www.cidh.oas.org/relatoria/section/Estudio \%20Espe

cial $\% 20$ sobre $\% 20$ el $\% 20$ derecho $\% 20 \mathrm{de}^{2} \% 20$ Acceso $\% 20 \mathrm{a} \% 201$ a $\% 20$ Informacion.pdf

Redondo García, M. y Campos-Domínguez, E. (2016). “La

transparencia mediática como mecanismo de autorregulación: análisis de su presencia en las webs de los principales medios españoles". Ambitos, 32, 1-18. Disponible en:

http:/ / www.redalyc.org/articulo.oa?id $=16845702008$

\section{Otros documentos:}

Carta de los Derechos Fundamentales de la Unión Europea. Diario Oficial de la Unión Europea. Bruselas, 18 de diciembre de 2000, pp. C 364/1- C 364/22. Disponible en: http://www.europarl.europa.eu/charter/pdf/text es.pdf

Convenio Europeo para la Protección de los Derechos Humanos y de las Libertades Fundamentales. Estrasburgo: Tribunal Europeo de Derechos Humanos, Consejo de Europa. Disponible en: https://www.echr.coe.int/Documents/Convention SPA.pdf

Convenio del Consejo de Europa sobre el Acceso a los Documentos Públicos. Tromsø (Noruega): Consejo de Europa. Disponible en: file:///C:/Users/Usuario/Downloads/19-06- 
2009\%20Convenio $\% 20$ del $\% 20$ Consejo $\% 20$ de $\% 20$ Europa $\% 2$ 0sobre $\% 20 \mathrm{el} \% 20$ Acceso $\% 20 \mathrm{a} \% 201$ los $\% 20$ Documentos $\% 20 \mathrm{P}$ $\%$ C3\%BAblicos $\% 20(1)$.pdf

Reglamento (CE) núm. 1049/2001, del Parlamento Europeo y del Consejo, de 30 de mayo de 2001, relativo al acceso del público a los documentos del Parlamento Europeo, del Consejo y de la Comisión. Diario Oficial de la Unión Europea. Bruselas, 31 de mayo de 2001, pp. L 145/43- L 145/48. Disponible en: https://www.boe.es/doue/2001/145/L00043-00048.pdf

Tratado de Funcionamiento de la Unión Europea (versión consolidada). Diario Oficial de la Unión Europea. Bruselas, 30 de marzo de 2010, pp. C 83/47- C 83/199. Disponible en: https://www.boe.es/doue/2010/083/Z00047-00199.pdf

Tratado de la Unión Europea (versión consolidada). Diario Oficial de la Unión Europea. Bruselas, 30 de marzo de 2010, pp. C 83/13- C 83/45. Disponible en:

https://www.boe.es/doue/2010/083/Z00013-00046.pdf

Tratado por el que se establece una Constitución para Europa. Diario Oficial de la Unión Europea. Bruselas, 16 de diciembre de 2004, pp. C 310. Disponible en: https://eur-lex.europa.eu/legalcontent/ES/TXT/?uri=OJ:C:2004:310:TOC

\begin{abstract}
Agradecimientos
Esta publicación se enmarca en los trabajos de los proyectos de investigación "Indicadores de gobernanza, financiación, rendición de cuentas, innovación, calidad y servicio público de las RTV europeas aplicables a España en el contexto digital" (CSO2015-66543-P) y "DEBATv, Debates Electorales Televisados en España: Modelos, Proceso, Diagnostico y Propuesta" (CSO2017-83159-R), financiados ambos por el Ministerio de Ciencia, Innovación y Universidades y la Agencia Estatal de Investigación (AEI) del Gobierno de España, con el apoyo del Fondo Europeo de Desarrollo Regional (FEDER) de la Unión Europea (UE). Surge también de la actividad investigadora de XESCOM: Red Internacional de Investigación de la Gestión de la Comunicación, proyecto de investigación financiado en régimen de concurrencia competitiva por la Consellería de Cultura, Educación e Ordenación Universitaria de la Xunta de Galicia (ED341D R2016/019).
\end{abstract}





\title{
Presencia de las televisiones públicas españolas en la red social Menéame
}

\author{
Begoña Zalbidea \\ Idoia Camacho \\ Jose Mari Pastor \\ Santi Urrutia \\ Universidad del País Vasco
}

PARA CITAR: Zalbidea, B., Camacho, I., Pastro, J.M. y Urrutia, S. (2018). Presencia de las televisiones públicas españolas en la red social menéame. En Rodríguez-Castro, M., Pérez-Seijo, S. y Campos-Freire, F. (Eds.). La TV Pública en Europa: Innovación, Retos y Tendencias (193-205). Cuadernos Artesanos de Comunicación, cac 146. La Laguna (Tenerife): Latina. DOI: 10.4185/cac146.

\section{Resumen}

El objeto del estudio ha sido conocer el peso que tienen las televisiones públicas españolas en la portada de Menéame, la red social de noticias más importante de habla hispana. La investigación se ha llevado a cabo con una muestra aleatoria de 8.000 unidades informativas de un total de 156.800 unidades de diversa procedencia que los usuarios de la red subieron a portada con sus votos a lo largo de diez años (2006-2015). Los resultados señalan que las noticias procedentes de televisiones públicas no han tenido prácticamente ninguna relevancia en el conjunto de esas informaciones. Únicamente el $0,7 \%$ remiten a televisiones públicas estatales (casi todas a RTVE y EITB). De ello se concluye que, de cara al futuro, las televisiones públicas tienen un enorme reto para conectar con los intereses de los usuarios de este tipo de redes sociales. 
Palabras clave: televisión pública, redes sociales, RTVE, Menéame.

\section{Introducción}

Las redes sociales y los sitios creados para que los usuarios compartan y promuevan noticias procedentes de otros medios tienen cada vez más incidencia y aceptación entre la ciudadanía. En esta práctica por capturar y difundir contenidos ajenos, el foco de interés repasa y recorre los distintos soportes, donde quedan incluidas las televisiones públicas. Por ello, resulta fundamental estudiar el peso que tienen las informaciones procedentes de dichas cadenas en las redes, porque el futuro de las primeras pasa, entre otras cuestiones, por conseguir que sus noticias aparezcan enlazadas en las segundas.

La distribución de noticias dejó de ser hace mucho tiempo un privilegio de los editores. Cualquier usuario de la red puede compartir contenidos, y sus visitantes muestran un comportamiento distinto en la manera de acceder a las noticias: buscan referencias, contenido interesante, fuentes fiables o elementos comunicativos con alto valor informacional o de relevancia. Es lo que se desprende de estudios individuales y colectivos firmados por autores como Ramonet (2011); Bakshy et al. (2011); Bandari et al. (2012) o Rudat et al. (2014), respectivamente. Esta diversidad de prácticas presenta, entre otros, un efecto singular: que las audiencias acceden a informaciones a las que no hubieran llegado de otra manera (Kümpel et al., 2015: 1-6).

Los agregadores de noticias son un tipo particular de redes sociales en las que los usuarios promueven y suben a portada informaciones relevantes a través de sus votos. La procedencia puede ser diversa: medios convencionales y online, sitios web, blogs, agencias, etc. En esta investigación se pretende conocer el interés de los usuarios de la red por las aportaciones informativas de las televisiones públicas españolas. El estudio se centra en Menéame, el agregador de noticias más importante de habla hispana.

\section{El impacto de las redes sociales en las televisiones y viceversa}

La intersección entre las redes sociales y las televisiones da lugar a diferentes vertientes de análisis: de dónde recoge la ciudadanía las 
informaciones; qué influencia tienen las redes sociales en las televisiones; cómo afectan las televisiones a las redes sociales; qué contenidos de las televisiones son los que más se divulgan y comentan en las redes sociales.

Esa relación entre las televisiones públicas ha sido objeto de diversos estudios en los que se analiza el modo en que estos medios audiovisuales pueden acercarse a nuevas audiencias sin comprometer sus valores sociales (Van Dijck y Poell, 2014: 148).

Numerosas investigaciones tratan del impacto de las redes sociales en las televisiones, utilizando ejemplos de acontecimientos sociales y políticos grabados con dispositivos de personas individuales y compartidos posteriormente en las redes sociales. Hay casos relevantes de sucesos recogidos únicamente de esta forma que, posteriormente, han sido distribuidos a través de medios convencionales como las televisiones. Los acontecimientos relacionados con las denominadas primaveras árabes se divulgaron básicamente de esa forma (Alsayyad y Guvenc, 2015: 2024-2025).

En cuanto al tipo de contenidos de las televisiones que más e comparten en las redes sociales, hay estudios que señalan que ello se produce, sobre todo, en relación a los productos de ficción, entretenimiento y deportes (Gómez et al., 2015, 539). Otras investigaciones han tenido en cuenta de dónde obtienen información los ciudadanos sobre determinados temas. En un estudio trabajo realizado con jóvenes para conocer las fuentes de las que se sirven para conocer noticias de una campaña electoral, la televisión aparece como soporte prevalente, aunque también los medios sociales resultan influyentes (Lago-Vázquez et al., 2016: 1151-1152).

La intersección de la televisión con las redes sociales ha dado lugar a lo que se ha venido a denominar televisión social, que permite a los espectadores compartir en cualquier momento y lugar el contenido que más les interesa. Konstantinos Chorianopoulos y George Lekakos (2008: 116) señalan que la televisión social tiene como objetivo lograr "una comunicación interpersonal virtual por encima de la distancia y el tiempo". En este mismo sentido, Buschow, Schneider y Ueberheide mencionan el "intercambio comunicativo" que se crea entre los 
usuarios al comentar y/o compartir contenidos televisivos lineales (Buschow, Schneider \& Ueberheide, 2014: 131).

Algunos autores han llamado audiencia social a la conformada por los usuarios de Twitter que escriben algo relacionado con un espectáculo televisivo desde 30 minutos antes a 30 minutos después de su emisión (Jenkins, 2008). Precisamente, España es uno de los países con mayor desarrollo de la audiencia social en el mundo, y el primero en Europa. Un estudio de WitsspottER indica que, junto con Brasil, Argentina, Chile y USA, España lidera el ranking de los países más activos en redes sociales en relación a los comentarios sobre contenidos televisivos, siendo su probable causa la alta penetración de dispositivos móviles (Quintas-Froufe et al., 2015: 29).

Como se ha apuntado, un agregador de noticias se dedica, básicamente, a promover para subir a su portada las informaciones que los usuarios consideran más relevantes. El interés que, a priori, pudiera despertar el conocimiento sobre su actividad y sus aportaciones, es, en general, escasa, si se exceptúan los estudios relacionados con el agregador de noticias más importante de lengua inglesa Digg. Sin embargo, tampoco en este caso se presta especial atención a las noticias procedentes de las televisiones que consiguen llegar a portada.

\section{Método}

La investigación se ha llevado a cabo con una muestra aleatoria de 400 portadas, del total de las 7.840 correspondientes a diez años de Menéame. Ello significa que se ha trabajado con un nivel de confianza del $95,5 \%$ y un error muestral de $5 \%$. Cada portada consta de 20 noticias, por lo que se han analizado 8.000 unidades.

Entre las variables que se han medido, y que se tratan en esta investigación, figuran la procedencia y la temática. La correspondiente a procedencia ha sido clasificada en nueve categorías: 1) Medio estatal online que deriva de otro offline; 2) Medio extranjero online que deriva de otro offline; 3) Medio estatal exclusivamente online; 4) Medio extranjero exclusivamente online; 5) Agencia; 6) Red social; 7) Portalsitio web; 8) Blog; 9) Otros. Por su parte, la temática se ha dividido en catorce categorías. Nueve de ellas coinciden con las utilizadas frecuentemente en el análisis de los medios: Política, Economía, 
Justicia, Salud, Educación, Sociedad, Cultura y espectáculos, Ciencia y tecnología y Deportes. Cuatro de ellas han sido incluidas por su especial trascendencia en el ámbito español durante el período analizado: Corrupción, LGTB, Inmigración y Violencia y discriminación contra la mujer. Finalmente, "Otros" acoge las noticias que no se pueden encasillar en las anteriores.

En cuanto a la variable procedencia, la investigación se ha centrado en las dos categorías relacionadas con medios estatales: "Medio estatal online que deriva de otro offline", donde se incluyen las televisiones públicas, y "Medio estatal exclusivamente online". Por otra parte, en lo que se refiere a la variable Temática, la misma se analiza en las noticias procedentes de las televisiones públicas que han alcanzado la portada de Menéame.

\section{Resultados}

\subsection{Las televisiones públicas en el contexto de los medios estatales que aportan noticias a Menéame}

En los diez primeros años de su existencia (2006-2015), los usuarios de la red social Menéame subieron a portada del agregador, mediante sus votos, 156.800 noticias de diversa procedencia (medios tradicionales y online, sitios web, blogs, etc.) y origen (estatales e internacionales).

Los medios estatales, tanto los que tienen origen offline como los que son exclusivamente online, tienen un gran peso en el agregador Menéame: 45,1\% del total en los diez años. La mayor parte procede de medios que tienen origen offline: 2.549 noticias (31,9\% del total). Mientras tanto, otras $1.060(13,2 \%)$ lo hacen de soportes exclusivamente online.

Podemos observar los diez medios más importantes con origen offline, donde se refleja la importancia de las grandes cabeceras de prensa, y los diez meramente online (Tabla 1). 
Tabla 1. Los diez medios de origen offline y online con mayor presencia en la portada de Menéame

\begin{tabular}{|l|r|l|r|}
\hline Medio de origen offline & $\mathbf{N}^{\mathbf{0}}$ noticias & Medio de origen online & $\mathbf{N}^{\mathbf{0}}$ noticias \\
\hline elmundo.es & 286 & eldiario.es & 125 \\
\hline elpais.com & 282 & elconfidencial.com & 123 \\
\hline publico.es & 199 & lainformacion.com & 85 \\
\hline 20minutos.es & 165 & vozpopuli.com & 52 \\
\hline lavanguardia.com & 122 & elplural.com & 47 \\
\hline abc.es & 120 & libertaddigital.com & 29 \\
\hline ecodiario.eleconomista.es & 110 & soitu.es & 20 \\
\hline cadenaser.com & 77 & huffingtonpost.es & 17 \\
\hline elperiodico.com & 67 & diagonalperiodico.net & 17 \\
\hline lavozdegalicia.es & 51 & elmundotoday.com & 21 \\
\hline
\end{tabular}

Fuente: elaboración propia.

Hay que precisar que a finales de 2013 y comienzos de 2014 desaparecen de Menéame siete de estos medios con origen offline. Se trata de El Mundo, El País, Abc, El Economista, El Periódico, La Voz de Galicia y La Vanguardia. La causa fue el boicot planteado por los usuarios ante la pretensión de los editores de dichos medios de cobrar un canon a la web. Como consecuencia, el número de noticias procedentes de esas cabeceras sufre un drástico descenso, por lo que pasa a tener menos de la mitad del peso que había tenido hasta entonces, bajando a un 13,75\%. La medida, empero, no afecta a los medios convencionales Público, 20minutos.es y Cadena Ser.

Los resultados permiten afirmar que la pérdida descrita se suple en gran medida con la aportación procedente de la categoría de medios estatales exclusivamente online. Estos últimos llegan casi a doblar el peso que habían tenido previamente, alcanzando el 29,2\% del total. El resultado es que entre ambas categorías siguen alcanzando el 43\% durante los dos últimos años. Entre los medios exclusivamente online, destacan los siguientes: eldiario.es, elconfidencial.com, vozpopuli.com, lainformacion.com y elplural.com. 


\subsection{Panorámica de medios audiovisuales estatales}

Dentro de la categoría de medios con origen offline están los medios audiovisuales. A continuación, ofrecemos una panorámica general de la contribución de tales medios al agregador Menéame.

Tabla 2. Panorámica de medios audiovisuales estatales

\begin{tabular}{|c|c|c|c|c|}
\hline Medios & Número & $\%$ & Radio/TV & Público/privado \\
\hline antena3.com & 5 & $2,5 \%$ & TV & Privado \\
\hline cadenaser.com & 77 & $37,9 \%$ & Radio & Privado \\
\hline canalsur.es & 1 & $0,5 \%$ & TV & Público \\
\hline cityfmradio.com & 1 & $0,5 \%$ & Radio & Privado \\
\hline cope.es & 3 & $1,5 \%$ & Radio & Privado \\
\hline cuatro.com & 6 & $3,0 \%$ & TV & Privado \\
\hline eitb.com & 16 & $7,9 \%$ & TV & Publico \\
\hline informativos.net & 1 & $0,5 \%$ & TV & Privado \\
\hline lasexta.com & 25 & $12,3 \%$ & TV & Privado \\
\hline radiocable.com & 6 & $3,0 \%$ & Radio & Privado \\
\hline radiofusion.eu & 2 & $1,0 \%$ & Radio & Público \\
\hline radiohuesca.com & 1 & $0,5 \%$ & Radio & Privado \\
\hline rtvcyl.es & 2 & $1,0 \%$ & TV & Público \\
\hline rtve.es & 39 & $19,1 \%$ & TV & Publico \\
\hline telecinco.es & 16 & $7,8 \%$ & TV & Privado \\
\hline telemadrid.es & 1 & $0,5 \%$ & TV & Público \\
\hline vtelevision.es & 1 & $0,5 \%$ & TV & Privado \\
\hline Total & 203 & $100 \%$ & & \\
\hline
\end{tabular}

Fuente: elaboración propia.

En total han sido 24 radios y televisiones las que han nutrido con sus noticias al agregador durante los diez años de estudio. De ese conjunto, 14 han sido medios privados y 10 públicos, siendo 203 las noticias proporcionadas. Esto significa que solo un 2,5\% del total de noticias que han alcanzado la primera página han procedido de estas fuentes, lo 
que indica claramente el bajísimo peso que tienen los medios audiovisuales españoles en ese agregador.

La aportación entre los medios audiovisuales privados y público sitúan la muestra en cifras que indican que 142 noticias proceden de privados y 61 de públicos, por lo que se puede extrapolar a todo el universo de las noticias de Menéame señalando que los medios privados han proporcionado un $1,7 \%$ de las noticias y los públicos $0,8 \%$. Ahondando entre tipos de medios audiovisuales, las televisiones han proporcionado 113 informaciones y las radios 90 . Es decir, 1,4\% de las noticias de portada de Menéame proceden de televisiones estatales, y $1,1 \%$ de radios, también estatales.

\subsection{Noticias procedentes de televisiones públicas y privadas}

Las televisiones públicas han tenido una relevancia muy escasa en el conjunto de las informaciones promovidas por la red social Menéame. De todas, aquellas cuyos enlaces remitían a televisiones públicas estatales supusieron únicamente el 0,74\%. Las cadenas de televisión privadas lograron un porcentaje similar $(0,66 \%)$.

Tabla 3. Televisiones públicas y privadas que han proporcionado noticias a Menéame

\begin{tabular}{|l|r|l|r|}
\hline \multicolumn{1}{|c|}{ TV públicas } & $\begin{array}{c}\mathbf{N}^{\mathbf{0}} \\
\text { noticias }\end{array}$ & TV privadas & $\begin{array}{c}\mathbf{N}^{\mathbf{0}} \\
\text { noticias }\end{array}$ \\
\hline canalsur.es & 1 & antena3.com & 5 \\
\hline eitb.com & 16 & cuatro.com & 25 \\
\hline rtvcyl.es & 2 & lasexta.com & 16 \\
\hline rtve.es & 39 & telecinco.es & 1 \\
\hline telemadrid.es & 1 & vtelevision.es & $\mathbf{5 3}$ \\
\hline Total & $\mathbf{5 9}$ & Total & \\
\hline
\end{tabular}

Fuente: elaboración propia.

Dentro de la muy escasa aportación de las televisiones públicas, RTVE es la cadena que destaca, seguida de la autonómica EITB. La presencia del resto de cadenas de televisión públicas en la portada del agregador 
es prácticamente nula. Con respecto a los canales privados, La Sexta se coloca en primer lugar, seguida de Telecinco.

\subsection{Temática de las noticias procedentes de RTVE}

La Tabla 4 muestra cómo se dividen las noticias procedentes de RTVE en base a la temática.

Tabla 4. Temática de las noticias procedentes de RTVE en Menéame

\begin{tabular}{|l|r|}
\hline \multicolumn{1}{|c|}{ Temática } & \multicolumn{1}{c|}{$\%$} \\
\hline Ciencia y tecnología & $7,7 \%$ \\
\hline Corrupción & $5,1 \%$ \\
\hline Cultura y espectáculos & $10,3 \%$ \\
\hline Deportes & $5,1 \%$ \\
\hline Economía & $7,7 \%$ \\
\hline Educación & $5,1 \%$ \\
\hline LGTB & $2,6 \%$ \\
\hline Política & $28,2 \%$ \\
\hline Salud & $10,3 \%$ \\
\hline Sociedad & $15,4 \%$ \\
\hline $\begin{array}{l}\text { Violencia y discriminación } \\
\text { contra la mujer }\end{array}$ & $2,6 \%$ \\
\hline Total & $\mathbf{1 0 0} \%$ \\
\hline
\end{tabular}

Fuente: elaboración propia.

Más de la mitad de las noticias que proceden de RTVE en Menéame corresponden al tipo de las denominadas "noticias duras" (51,3\%). Se trata de Política, Economía, Corrupción, Educación, LGTB, y Violencia y discriminación contra la mujer. El dato choca de forma importante con los resultados de otros estudios que señalan que las temáticas más utilizadas en las redes sociales relacionadas con las televisiones son las que tienen que ver con los espectáculos y el entretenimiento. 
No sólo eso, si observamos las diez noticias provenientes de RTVE que han provocado más comentarios entre los usuarios de Menéame, vemos que todas menos una pertenecen al tipo de noticias consideradas más relevantes desde el punto de vista socio-político (Ver tabla 5).

\section{Tabla 5: Diez titulares de Menéame vinculados a RTVE con más comentarios}

\begin{tabular}{|l|l|c|}
\hline Titular & Temática & Comentarios \\
\hline $\begin{array}{l}\text { Un senador del PP: "Ya no estamos en campaña; } \\
\text { es momento de decir lo que de verdad pensamos" }\end{array}$ & Política & 234 \\
\hline $\begin{array}{l}\text { Fidel Castro califica a España de "minipotencia" y } \\
\text { "viejo imperio en muletas" }\end{array}$ & Política & 137 \\
\hline $\begin{array}{l}\text { El primer ministro italiano, Mario Monti, afirma } \\
\text { que es "aburrido" tener un trabajo fijo para toda } \\
\text { la vida }\end{array}$ & Política & 125 \\
\hline Un kebab casi dobla en calorías a un Big Mac & Sociedad & 123 \\
\hline $\begin{array}{l}\text { Informe Semanal: Vidas hipotecadas } \\
\text { El PNV acusa al PSE de querer instaurar un } \\
\text { "sistema de golpe institucional" }\end{array}$ & Política & 118 \\
\hline $\begin{array}{l}\text { Tres periodistas españoles freelance, secuestrados } \\
\text { en Siria }\end{array}$ & Política & 116 \\
\hline $\begin{array}{l}\text { El infierno en las aulas: "Me tiró contra la mesa } \\
\text { mientras me gritaba te voy a matar hija de p..." }\end{array}$ & Educación & 100 \\
\hline $\begin{array}{l}\text { La reforma educativa prevé un certificado escolar } \\
\text { oficial para los que no terminen la ESO }\end{array}$ & Educación & 91 \\
\hline $\begin{array}{l}\text { Sarkozy afirma que el burka, "signo de esclavitud" } \\
\text { de la mujer, "no es bienvenido" en Francia }\end{array}$ & $\begin{array}{l}\text { Violencia } \\
\text { discriminación } \\
\text { contra la mujer }\end{array}$ & y \\
\hline
\end{tabular}

Fuente: elaboración propia. 


\section{Conclusiones}

Los medios en general, tanto los convencionales como los exclusivamente online, tienen un gran peso en la red social Menéame. En el conjunto de los diez años analizados (2006-2015) el porcentaje de las noticias procedentes de esos medios alcanzó casi la mitad $(45,1 \%)$. Ahora bien, los convencionales tuvieron un descenso drástico en 2014 y 2015 debido al boicot de los usuarios por el acuerdo alcanzado entre algunos editores para cobrar un canon por la vinculación de sus noticias, lo que se popularizó como "Tasa Google". Los medios exclusivamente online, sin embargo, suplieron casi en su totalidad esa pérdida.

Dentro de esas mismas categorías, el peso de la aportación de los medios audiovisuales estatales, tanto públicos como privados, es muy bajo en todo el período: sólo un 2,5\% de las informaciones aparecen vinculadas a estas radios y televisiones.

Dentro de dichos medios, las televisiones públicas tienen una relevancia ínfima en el conjunto de las informaciones promovidas por los usuarios del agregador de noticias Menéame. De las 156.800 noticias de diversa procedencia que los usuarios subieron a portada con sus votos a lo largo de diez años (2006-2015) únicamente el 0,7\% remiten a televisiones públicas estatales (RTVE y EITB).

Con todo, hay que subrayar que la mayoría de las noticias recogidas en el agregador procedentes de las televisiones públicas presentan una temática relacionada con las "noticias duras": destacan categorías como Política, Economía y Educación. Este dato contrasta notablemente con la visión más generalizada de que los usuarios de las redes prefieren en su consumo de televisión las informaciones relacionadas con los espectáculos y el entretenimiento.

Resumiendo, el dato de que los usuarios de Menéame vinculen preferentemente noticias duras procedentes de las televisiones públicas resulta alentador con respecto a la evolución de la opinión pública en el contexto de las nuevas tecnologías de la comunicación. Sin embargo, si el futuro de las televisiones públicas pasa por tener incidencia en las redes sociales, el dato sobre el número de noticias enlazadas resulta tremendamente desalentador. Hasta ahora estas televisiones no han 
sido capaces de conectar mínimamente con los intereses de los usuarios de la red social Menéame.

\section{Referencias}

AlSayyad, N. y Guvenc, M. (2015): "Virtual Uprisings: On the Interaction of New Social Media, Traditional Media Coverage and Urban Space during the 'Arab Spring.' Urban Studies 52(11) 2018-2034.

Bakshy E., Hofman J.M., Mason W.A. y Watts D.J. (2011): "Everyone's an influencer: Quantifying influence on Twitter". In: Proceedings of the Fourth ACM International Conference on Web Search and Data Mining. New York: ACM, pp. 65-74.

Bandari, R., Asur, S., y Huberman, B. A. (2012): The pulse of news in social media: Forecasting popularity (CoRR, abs/1202.0332). Accesible en: http://arxiv.org/abs/1202.0332 (visitado el 8/5/2018).

Buschow, C., Scheider, B., y Ueberheide, S. (2014): “Tweeting Television: Exploring Communication Activities on Twitter while Watching TV'. Communications: European Journal of Communication Research 39 (2), pp. 129-149.

Chorianopoulos, K., Lekakos, G. (2008): "Introduction to Social TV: Enhancing the Shared Experience with Interactive TV". International Journal of Human-Computer Interaction 24 (2), pp. 113-120.

Gómez, M., Paniagua, F.J. y Farias, P. (2015): “The behaviour of the television audience on social networks. An approach to its profile and the most talked-about programmes". Revista Latina de Comunicación Social, 70, 539-551.

Jenkins, H. (2008): Convergence culture: La cultura de la convergencia de los medios de comunicación. Barcelona: Paidós. 
Kümpel, A.S., Karnowski, V. y Keyling, T. (2015): “News Sharing in Social Media: A Review of Current Research on News Sharing Users, Content, and Networks," Social Media + Society, July-December: 1-14.

Lago-Vázquez, D., Direito-Rebollal, S., Rodríguez-Vázquez, A.I. y López-García, X. (2016): "Millennials"e consumption of political information on television and social networks. An analysis of the 2015 Spanish general election campaign". Revista Latina de Comunicación Social, 71, 1.151-1.169.

Quintas-Froufe, N., González-Neira, A. y Díaz-González, M.J. (2015): "The communication strategy developed on Twitter to promote a mockumentary: Operación Palace". Revista Latina de Comunicación Social, 70, 28-48.

Rudat A., Buder J. y Hesse F.W. (2014): “Audience design in Twitter: Retweeting behavior between informational value and followers' interests". Computers in Human Behavior 35: 132-139.

Van Dijck, J., Poell, T. (2014): "Making Public Television Social? Public Service Broadcasting and the Challenges of Social Media". Television and New Media 16, (2), pp. 148-164.

\section{Reconocimientos de la investigación}

Este trabajo forma parte del proyecto "Reacciones desde la ética ciudadana en la red social Menéame, ante los contenidos de los medios de comunicación convencionales y sociales en España", financiada por el Ministerio de Industria, Economía y Competitividad (Referencia: CSO2014-59077-R). 



\title{
Análisis económico comparativo vertical de las empresas privadas televisivas nacionales de Ecuador: Teleamazonas - Ecuavisa
}

\author{
Ana Cecilia Vaca-Tapia \\ Pontificia Universidad Católica del Ecuador Sede Ibarra \\ Universidade de Santiago de Compostela \\ Francklin Iván Rivas-Echeverría \\ Universidad Técnica Federico Santa María, Chile \\ Pontificia Universidad Católica del Ecuador Sede Ibarra \\ Johnny Alejandro Aragón-Puente \\ Pontificia Universidad Católica del Ecuador Sede Ibarra
}

PARA CITAR: Vaca-Tapia, A.C., Rivas-Echeverría, F.I. y Aragón-Puente, J.A. (2018). Análisis comparativo de los resultados económicos de las empresas privadas televisivas nacionales de Ecuador. En Rodríguez-Castro, M., PérezSeijo, S. y Campos-Freire, F. (Eds.). La TV Pública en Europa: Innovación, Retos y Tendencias (207-225). Cuadernos Artesanos de Comunicación, cac 146. La Laguna (Tenerife): Latina. DOI: 10.4185/cac146.

\section{Resumen}

En este trabajo se reúne y analiza la información contable correspondiente al año 2016 de las empresas televisivas privadas nacionales de Ecuador: Teleamazonas y Ecuavisa. Se seleccionan estas dos compañías de televisión privadas nacionales considerando en primer lugar su nivel de rating localizado en One TV Year in the world (2016) y adicionalmente porque ambas presentan un mismo fenómeno 
que consiste en tener un nombre comercial pero dos diferentes razones sociales asociadas a sedes localizadas en diferentes lugares del país. El estudio económico se realiza mediante un sistema experto de análisis financiero que permite la optimización de recursos y la toma de decisiones para el crecimiento empresarial. Se aplica el método vertical que consta de los factores de liquidez, solvencia, gestión y rentabilidad. Los resultados permiten conocer la realidad económica al año 2016, analizar el desempeño y determinar las áreas débiles de las dos televisoras.

Palabras clave: televisión, análisis económico, sistema experto.

\section{Introducción}

El estudio de los estados financieros es un proceso por el que el analista, mediante transformaciones, representaciones gráficas, ratios y otros cálculos, obtiene una opinión a partir de los documentos económicos y otra información complementaria, evaluando la liquidez, solvencia, gestión y rentabilidad de la empresa (Bonsón, Cortijo \& Flores, 2009: 209).

Los métodos de análisis de los estados financieros pueden clasificarse en dos grandes grupos: Métodos Verticales, se analizan cifras de un solo ejercicio fiscal o período contable y Métodos Horizontales que analizan la información financiera de varios años (Arias 2012). Se analizan las cifras de la anualidad 2016.

Según la Superintendencia de Compañías, Valores y Seguros (2016), los indicadores financieros son: Liquidez, Solvencia, Gestión y Rentabilidad. Información base al igual que el criterio del experto para el desarrollo del sistema de análisis financiero, herramienta informática que, mediante inteligencia artificial, ayuda al procesamiento de la información económico-financiera.

En este contexto, se analizan comparativamente los datos económicos de las dos empresas privadas televisivas nacionales: Teleamazonas y Ecuavisa. Compañías que manejan un nombre comercial pero dos diferentes razones sociales, como se muestra en la Figura 1. 
Figura 1. Información de los medios televisivos privados de carácter nacional de Ecuador: Teleamazonas y Ecuavisa

\begin{tabular}{|c|c|c|c|c|c|c|}
\hline \multirow[t]{2}{*}{ RUC } & \multirow[t]{2}{*}{ Razón social } & \multirow[t]{2}{*}{$\begin{array}{l}\text { Nombre } \\
\text { comercial }\end{array}$} & \multirow[t]{2}{*}{ Clasificación } & \multirow[t]{2}{*}{ Cobertura } & \multicolumn{2}{|c|}{$\begin{array}{c}\text { Domicilio declarado } \\
\text { por el medio/sede } \\
\text { defensor de } \\
\text { audiencias }\end{array}$} \\
\hline & & & & & Provincia & Cantón \\
\hline $\begin{array}{l}17912603 \\
76001\end{array}$ & $\begin{array}{l}\text { Centro de Radio } \\
\text { y Televisión } \\
\text { Cratel C.A }\end{array}$ & $\underline{\text { TELEAMAZONAS }}$ & $\begin{array}{l}\text { Televisión } \\
\text { abierta } \\
\text { VHF }\end{array}$ & $77,79 \%$ & Pichincha & Quito \\
\hline $\begin{array}{l}17908438 \\
31001\end{array}$ & $\begin{array}{l}\text { Teleamazonas } \\
\text { Guayaquil S.A. }\end{array}$ & TELEAMAZONAS & $\begin{array}{l}\text { Televisión } \\
\text { abierta } \\
\text { VHF }\end{array}$ & $177,79 \%$ & Pichincha & Quito \\
\hline $\begin{array}{l}99012613 \\
5001\end{array}$ & $\begin{array}{l}\text { Corporación } \\
\text { Ecuatoriana De } \\
\text { Televisión S.A. }\end{array}$ & $\underline{E C U A V S A}$ & $\begin{array}{l}\text { Televisión } \\
\text { abierta } \\
\text { UHF }\end{array}$ & $70,70 \%$ & Guayas & Guayaquil \\
\hline $\begin{array}{l}17900362 \\
43001\end{array}$ & $\begin{array}{l}\text { Televisora } \\
\text { Nacional } \\
\text { Compañía } \\
\text { Anónima } \\
\text { Telenacional C.A }\end{array}$ & $\underline{E C U A V S A}$ & $\begin{array}{l}\text { Televisión } \\
\text { abierta } \\
\text { VHF }\end{array}$ & $170,70 \%$ & Guayas & Guayaquil \\
\hline
\end{tabular}

Fuente: Adaptado del Consejo de Regulación y Desarrollo de la Información y Comunicación (2015)

Para Jauset (2003) los resultados o estimaciones de las audiencias son la moneda de cambio aceptada para las transacciones en el mercado publicitario. Las cifras de audiencia son los índices determinantes de los ingresos o financiación de una determinada cadena y por tanto decisorios en la continuidad o desaparición de un determinado programa. Existen ya muchos precedentes de programas que se han emitido una sola vez al no alcanzarse los índices de audiencia previstos (p. 59).

Es así que este análisis toma el nivel rating de las dos compañías en estudio localizado en One TV Year in the world (2016), como se muestra en la Figura 2. 
Figura 2. Niveles de rating de Teleamazonas y Ecuavisa

\begin{tabular}{|c|c|c|c|}
\hline & \multicolumn{3}{|c|}{$\begin{array}{l}\Delta \text { (Aumento en comparación con 2014) } \\
\nabla \text { (Disminución en comparación con } 2014\end{array}$} \\
\hline ECUAVISA & 14.6 & $\nabla$ & -0.6 \\
\hline TC TELEVISIÓN & 13.1 & $\nabla$ & -2.2 \\
\hline RED TELESISTEMA & 11.4 & $\triangle$ & 0.2 \\
\hline GAMA TV & 8.8 & $\Delta$ & 0.5 \\
\hline CANAL UNO & 8.4 & $\Delta$ & 1.8 \\
\hline TELEAMAZONAS & 7.2 & $\nabla$ & -1.7 \\
\hline OTROS & 36.5 & - & - \\
\hline
\end{tabular}

Fuente: One TV Year in the world. (2016). The overview of comumption and audiovisual landscapes in more tan 100 territories. Eurodata TV worldwide.

\section{Información de las empresas televisivas privadas nacionales de Ecuador en estudio}

Para el estudio económico comparativo de las dos empresas privadas televisivas nacionales en análisis, es necesario conocer tanto su objeto social, actividades y proceso de renovación de frecuencia para entender su realidad.

\subsection{Centro de Radio y Televisión CRATEL C.A.}

\section{Figura 3. Información General de Centro de Radio y Televisión CRATEL C.A.}

\begin{tabular}{lll}
\hline INFORMACIÓN & \multicolumn{1}{c}{ DESCRIPCIÓN } \\
\hline $\begin{array}{l}\text { Objeto social } \\
\text { actividades }\end{array}$ & $\mathbf{y}$ & Constituida en el Ecuador el 17 de junio de 1993 \\
& - & Actividad principal es la emisión de programas de televisión en \\
& el ámbito nacional e internacional, para cuyo efecto podrá \\
& realizar producciones y proyectar filmes y producciones \\
& vinculadas. \\
& Las operaciones de la Compañía se relacionan con el uso \\
& comercial del canal de televisión "TELEAMAZONAS", para lo \\
& cual la Compañía mantiene un contrato de concesión de \\
& frecuencia en proceso de renovación con el Estado Ecuatoriano \\
& el cual venció en julio del 2014. \\
\hline
\end{tabular}




\begin{tabular}{lll}
\hline & $-\begin{array}{l}\text { Los accionistas principales de la Compañía son: i) Grupo La } \\
\text { República de Perú con un 45\% del capital social; y, ejecutivos y } \\
\text { empleados de Cratel C.A. con el 55\%. }\end{array}$ \\
\hline $\begin{array}{l}\text { Proceso } \\
\text { renovación } \\
\text { frecuencia }\end{array}$ & de & $\begin{array}{l}\text { La Compañía se encuentra actualmente operando amparada en la } \\
\text { de }\end{array}$ \\
& $\begin{array}{l}\text { Disposición Transitoria Tercera del Reglamento para la } \\
\text { adjudicación de títulos habilitantes para el funcionamiento de medio } \\
\text { de comunicación social públicos, privados, comunitarios y sistemas }\end{array}$ \\
& de audio y video por suscripción (Resolución No. RTV-536-25- \\
& CONATEL-2013). De acuerdo al referido reglamento, el \\
& CONARTEL debía convocar a concurso a todos los sistemas de \\
& televisión que se encuentran operando amparados en dicha \\
& resolución, hasta el 29 de octubre del 2014. La Compañía presentó \\
& la documentación para su renovación en 3o de junio del 2016, \\
presentando todos los requisitos exigidos en el proceso. A la espera \\
de la conclusión de los procesos, los mismos que no tienen una \\
fecha definida.
\end{tabular}

Fuente: Adaptado de Superintendencia de Compañías, Valores y Seguros, (2016).

\subsection{Teleamazonas Guayaquil S.A.}

\begin{tabular}{|c|c|}
\hline INFORMACIÓN & DESCRIPCIÓN \\
\hline $\begin{array}{l}\text { Objeto social y } \\
\text { actividades }\end{array}$ & $\begin{array}{l}\text { - Fue constituida en Ecuador el } 11 \text { de febrero de } 1988 \text { y su actividad } \\
\text { principal es la emisión de programas de televisión en el ámbito } \\
\text { nacional e internacional, para cuyo efecto podrá realizar } \\
\text { producciones y proyectar films y producciones vinculadas. } \\
\text { Las operaciones de la Compañía se relacionan con el uso } \\
\text { comercial del canal de televisión TELEAMAZONAS", para este } \\
\text { efecto la Compañía mantiene un contrato de concesión de } \\
\text { frecuencia con el Estado Ecuatoriano el cual venció en marzo del } \\
2013 \text { y a la fecha de emisión de estos estados financieros, se } \\
\text { encuentra en proceso de negociación. } \\
\text { Los accionistas principales de la Compañía son: i) Grupo La } \\
\text { República de Perú con un } 45 \% \text { del capital social; y, ii) ejecutivos } \\
\text { y empleados de Cratel CA con el } 5596 \text {. La Compañía presta sus } \\
\text { servicios exclusivamente a su Compañía Relacionada Centro de } \\
\text { Radio y Televisión Cratel CA; debido a esta situación los } \\
\text { resultados de la operación de la Compañía dependen } \\
\text { fundamentalmente de los acuerdos y operaciones que mantiene } \\
\text { con dicha entidad. } \\
\text { Adicionalmente, la Compañía posee un convenio de uso de Marca } \\
\text { con Centro de Radio y Televisión CRATEL CA, convenio que le } \\
\text { confiere a Teleamazonas Guayaquil CA, sin exclusividad, licencia } \\
\text { y autorización para que use y explote la marca } \\
\text { TELEAMAZONAS identificando los servicios de televisión que } \\
\text { provee en la región costa. Este convenio tiene la duración de un } \\
\text { año, desde el } 1 \text { de enero de } 2016 \text { al } 31 \text { de diciembre de } 2016 \text {; }\end{array}$ \\
\hline
\end{tabular}




\begin{tabular}{|c|c|}
\hline & $\begin{array}{l}\text { pudiendo renovarse automáticamente por el mismo plazo en } \\
\text { forma indefinida. } \\
\text { - Además la Compañía contrata la compra y venta de otros } \\
\text { servicios a su relacionada Centro de Radio y Televisión CRATEL } \\
\text { CA, los cuales son detallados en la Nota } 15 \text {. }\end{array}$ \\
\hline $\begin{array}{l}\text { Proceso } \\
\text { renovación } \\
\text { frecuencia }\end{array}$ & $\begin{array}{l}\text { de La Compañía se encuentra actualmente operando amparada en la } \\
\text { de Disposición Transitoria Tercera del Reglamento para la adjudicación } \\
\text { de títulos habilitantes para el funcionamiento de medio de } \\
\text { comunicación social públicos, privados, comunitarios y sistemas de } \\
\text { audio y video por suscripción (Resolución No. RTV-536-25- } \\
\text { CONATEL-2013). De acuerdo al referido reglamento, el } \\
\text { CONARTEL debía convocar a concurso a todos los sistemas de } \\
\text { televisión que se encuentran operando amparados en dicha } \\
\text { resolución, hasta el } 29 \text { de octubre del 2014. La Compañía presentó la } \\
\text { documentación para su renovación en 3o de junio del 2016, } \\
\text { presentando todos los requisitos exigidos en el proceso. A la espera } \\
\text { de la conclusión de los procesos, los mismos que no tienen una fecha } \\
\text { definida. }\end{array}$ \\
\hline
\end{tabular}

Fuente: Adaptado de Superintendencia de Compañías, Valores y Seguros, (2016).

\subsection{Corporación Ecuatoriana de Televisión S.A.}

\section{Figura 5. Información General de Corporación Ecuatoriana de Televisión S.A.}

\begin{tabular}{|c|c|}
\hline INFORMACIÓN & DESCRIPCIÓN \\
\hline $\begin{array}{l}\text { Objeto social y } \\
\text { actividades }\end{array}$ & $\begin{array}{l}\text { - Fue constituida en la República del Ecuador en agosto } 25 \text { de } 1956 . \\
\text { Su principal actividad es la operación comercial de un canal de } \\
\text { televisión en la ciudad de Guayaquil y en otras ciudades dentro del } \\
\text { país. El accionista controlante de la Compañía es el Sr. Xavier E. } \\
\text { Alvarado Robles que tiene una participación del } 50.62 \% \text {. El } \\
\text { domicilio tributario de le Compañía es Cerro del Carmen S/N } \\
\text { diagonal al Sagrado Corazón de Jesús en la ciudad de Guayaquil. } \\
\text { - En diciembre } 18 \text { del 2015, mediante resolución No. SCVS-INC- } \\
\text { DNASD-SAS-15, la Superintendencia de Compañías aprobó el } \\
\text { cambio de denominación de corporación ecuatoriana de } \\
\text { televisión S.A. por Corporación Ecuatoriana de Televisión C. } \\
\text { Ltda. La cual fue inscrita en el Registro Mercantil en enero } 4 \text { del } \\
\text { 2016. } \\
\text { La compañía tiene, convenlo de uso de Marca otorgado a } \\
\text { Televisora Nacional C. A. Telonacional, que le confiere, sin } \\
\text { exclusividad, licencia y autorización para que la referida entidad } \\
\text { use y explote la marca ECUAVISA, identificando con ella los } \\
\text { servicios de televisión que provee. Este convenio tiene duración } \\
\text { de un año, con renovaciones automáticas anuales, siempre y } \\
\text { cuando ninguna de las partes exprese lo contrario. }\end{array}$ \\
\hline
\end{tabular}




\begin{tabular}{|c|c|}
\hline & $\begin{array}{l}\text { Adicionalmente, la Compañía tiene suscrito mediante acuerdos y } \\
\text { convenios otros servicios con su compañía relacionada Televisora } \\
\text { Nacional C. A. Telenacional, Ver notas } 20 \text { y } 21 \text {. }\end{array}$ \\
\hline $\begin{array}{l}\text { Proceso } \\
\text { renovación } \\
\text { frecuencia }\end{array}$ & $\begin{array}{l}\text { de Mediante Resolución No. 338-12-CONATEL • } 2010 \text { da fecha julio } 20 \\
\text { de del 2010, del Consejo Nacional de Telecomunicaciones } \\
\text { (CONATEL.), la Compañía se encuentra autorizada a operar un canal } \\
\text { de Televisión en la ciudad de Guayaquil (Canal 2) y } 11 \text { repetidoras que } \\
\text { cubren la Región Litoral y parte de la región sierra dentro del país. } \\
\text { Esta autorización tiene vigencia hasta el } 20 \text { de marzo del } 2020 \text {. }\end{array}$ \\
\hline
\end{tabular}

Fuente: Adaptado de Superintendencia de Compañías, Valores y Seguros (2016).

\subsection{Televisora Nacional Compañía Anónima Telenacional C.A.}

Figura 6. Información General de Teleamazonas Guayaquil S.A.

\section{INFORMACIÓN}

Objeto social y actividades

\section{DESCRIPCIÓN}

Fue constituida en la República del Ecuador en 1969, y su principal actividad es la operación comercial de un canal de televisión en la ciudad de Quito y en otras ciudades del país. A partir del 24 de noviembre de 2008, el principal accionista de la Compañía es Medired S. A., una empresa ecuatoriana, cuyo controlante final es el Sr. Xavier Alvarado Roca.

- La Compañía es concesionaria de la frecuencia del canal 8 de Quito de televisión abierta y 11 repetidoras que cubren la región sierra, oriente y parte de la región litoral. Esta concesión venció el 10 de marzo del 2012, por lo que actualmente la Compañía se encuentra gestionando la renovación del contrato de concesión de acuerdo a la normativa vigente.

- La Compañía tiene firmado un convenio de uso de Marca otorgado por su compañía relacionada local denominada Corporación Ecuatoriana de Televisión C. Ltda., el mismo que le confiere a Televisora Nacional Telenacional C. A., sin exclusividad, licencia y autorización para que use y explote la marca ECUAVISA identificando con ella los servicios de televisión que provee. Este convenio tiene la duración de un año, con renovaciones automáticas anuales si pudiendo renovarse automáticamente por el mismo plazo. Además, la Compañía contrata la compra y venta de otros servicios a su compañía relacionada denominada Corporación Ecuatoriana de Televisión C. Ltda.

\begin{tabular}{lll}
\hline $\begin{array}{l}\text { Proceso } \\
\text { renovación }\end{array}$ & $\begin{array}{l}\text { de } \\
\text { de }\end{array}$ & $\begin{array}{l}\text { La Compañía actualmente se encuentra operando amparada en lo } \\
\text { dispuesto por el Consejo Nacional de Telecomunicaciones en el Art. }\end{array}$ \\
& & 3 de la Resolución RTV-734-25-CONATEL-2014 de fecha octubre \\
& 22 del 2014 donde se indica que estaciones de Radiodifusión Sonora, \\
& Televisión abierta y Sistema de Audio y video por suscripción cuyos \\
& contratos vencieron antes y a partir de la Ley Orgánica de \\
\hline
\end{tabular}


Comunicación, continuarán operando hasta que el CONATEL, con sujeción a lo dispuesto en el artículo 83 del Reglamento General a la Ley Orgánica de Comunicación y demás normativa aplicable, disponga lo pertinente.

Durante el año 2016, la Compañía presentó documentación para participar en licitación para concurso público de concesión de frecuencias organizado por el ARCOTEL, la cual consta de 3 fases. En el primer trimestre del año 2017, mediante oficio No. ARCOTEL- DE-EEC-2017-00529 se notificó que Televisora Nacional C. A. pasa a la segunda fase de licitación en razón que logró las puntuaciones requeridas para tal efecto. Hasta mayo 15 del 2017, la Compañía se encuentra a la espera de un nuevo comunicado del CORDICOM quien evaluará los participantes de la segunda fase. Cabe indicar que no se establece un tiempo límite para concluir el referido concurso de licitación, sin embargo la Administración de la Compañía prevé que concluya hasta el cierre del año 2017.

Fuente: Adaptado de Superintendencia de Compañías, Valores y Seguros (2016).

Luego de conocer el objeto social, actividades y proceso de renovación de frecuencia, procedemos al ingreso de datos en el sistema experto de análisis financiero por el método vertical de razones simples.

El ingreso de los valores en el sistema experto se realiza según cada fórmula referente a los indicadores de Liquidez, Solvencia, Gestión y Rentabilidad como se muestra en la Figura 7. Las cuentas contables localizadas en los estados financieros como es el Balance General y el Estado de Resultados de las empresas analizadas, es la base para generar los índices. Esta información es recolectada del portal de documentos de la Superintendencia de Compañías, Valores y Seguros.

Figura 7. Indicadores Financieros

\begin{tabular}{clc}
\hline \multicolumn{1}{c}{ FACTOR } & \multicolumn{1}{c}{ INDICADORES } & \multicolumn{1}{c}{ FÓRMULA } \\
\hline \multirow{2}{*}{ I. LIQUIDEZ } & 1. Liquidez Corriente & Activo Corriente / Pasivo Corriente \\
\cline { 2 - 3 } & $\begin{array}{l}\text { 2. Prueba Ácida } \\
\text { II. SOLVENCIA }\end{array}$ & $\begin{array}{c}\text { Activo Corriente - Inventarios / Pasivo } \\
\text { Corriente }\end{array}$ \\
\cline { 2 - 3 } & $\begin{array}{l}\text { 2. Endeudamiento del } \\
\text { Activo }\end{array}$ & Pasivo Total / Activo Total \\
\cline { 2 - 3 } & $\begin{array}{l}\text { 3. Endeudamiento del } \\
\text { Activo Fijo }\end{array}$ & Pasivo Total / Patrimonio \\
\hline
\end{tabular}


5. Apalancamiento

Financiero
(Utilidad Antes de Impuesto) / (Utilidad Antes de Impuestos e Intereses / Activos

Totales)

\begin{tabular}{|c|c|c|}
\hline \multirow{7}{*}{ III. GESTIÓN } & 1. Rotación de Cartera & Ventas / Cuentas por Cobrar \\
\hline & 2. Rotación de Activo Fijo & Ventas / Activo Fijo \\
\hline & 3. Rotación de Ventas & Ventas / Activo Total \\
\hline & $\begin{array}{l}\text { 4. Período Medio de } \\
\text { Cobranza }\end{array}$ & (Cuentas por Cobrar * 365) / Ventas \\
\hline & 5. Período Medio de Pago & $\begin{array}{c}\text { (Cuentas y Documentos por Pagar * 365) / } \\
\text { Compras }\end{array}$ \\
\hline & $\begin{array}{l}\text { 6. Impacto Gastos } \\
\text { Administración y Ventas }\end{array}$ & $\begin{array}{c}\text { Gastos Administrativos y de Ventas / } \\
\text { Ventas }\end{array}$ \\
\hline & $\begin{array}{l}\text { 7. Impacto de la Carga } \\
\text { Financiera }\end{array}$ & Gastos Financieros / Ventas \\
\hline \multirow{6}{*}{$\begin{array}{c}\text { IV. } \\
\text { RENTABILIDAD }\end{array}$} & $\begin{array}{l}\text { 1. Rentabilidad Neta del } \\
\text { Activo (Du Pont) }\end{array}$ & $\begin{array}{c}\text { (Utilidad Neta / Ventas }) *(\text { Ventas / } \\
\text { Activo Total })\end{array}$ \\
\hline & 2. Margen Bruto & Ventas Netas - Costo de Ventas / Ventas \\
\hline & 3. Margen Operacional & Utilidad Operacional / Ventas \\
\hline & $\begin{array}{l}\text { 4. Rentabilidad Neta de } \\
\text { Ventas (Margen Neto) }\end{array}$ & Utilidad Neta / Ventas \\
\hline & $\begin{array}{l}\text { 5. Rentabilidad Operacional } \\
\text { del Patrimonio }\end{array}$ & Utilidad Operacional / Patrimonio \\
\hline & 6. Rentabilidad Financiera & $\begin{array}{c}\text { (Ventas / Activo)* (Utilidad Antes de } \\
\text { Impuestos e Intereses / Ventas)* (Activo } \\
\text { / Patrimonio) * (Utilidad Antes de } \\
\text { Impuestos / Utilidad Antes de Impuestos e } \\
\text { Intereses }) * \text { (Utilidad Neta / Utilidad Antes } \\
\text { de Impuestos) }\end{array}$ \\
\hline
\end{tabular}

Fuente: Superintendencias de Compañías, Valores y Seguros, (2008).

A continuación, se presenta la base de conocimiento del sistema experto de análisis financiero que permite generar conclusiones en el reporte final. 


\section{Base de conocimiento del sistema experto de análisis financiero mediante el método vertical}

La base de conocimiento se formó a partir de la información otorgada por la Superintendencia de Compañías, Valores y Seguros y la valoración del experto.

3.1 Factor de liquidez

\subsubsection{Liquidez corriente}

3.1.1.1 Índice hasta dos, se observa que la capacidad de la empresa para cubrir los compromisos corrientes con la totalidad de los activos corrientes, no es la óptima y se debe verificar la capacidad de crédito y la inversión del inventario.

3.1.1.2 Índice sobre dos, se observa que la capacidad de la empresa para cubrir los compromisos corrientes con la totalidad de los activos corrientes es óptima, entre más alto sea el coeficiente mayor es la posibilidad de cubrir inmediatamente sus obligaciones a corto plazo.

\subsubsection{Prueba ácida}

3.1.2.1 Índice bajo uno, se observa que la capacidad de la empresa para cubrir las obligaciones corrientes con los activos corrientes sin tomar en cuenta el inventario no es la óptima si este no es fácilmente convertible en efectivo, se sugiere revisar la cartera de la empresa y la inversión realizada en los mismos.

3.1.2.2 Índice uno a uno se observa que la capacidad de la empresa para cubrir las obligaciones corrientes con los activos corrientes sin tomar en cuenta el inventario es la óptima, ya que por cada dólar de deuda posee un dólar con disponibilidad inmediata.

3.1.2.3 Índice sobre uno se observa que la capacidad de la empresa para cubrir las obligaciones corrientes con los activos corrientes sin tomar en cuenta el inventario es la óptima, ya que por cada dólar de deuda posee más de un dólar con disponibilidad inmediata, pero se sugiere revisar si se realiza la inversión necesaria correctamente. 


\subsection{Factor de solvencia}

\subsubsection{Endeudamiento del activo}

3.2.1.1 Índice hasta el 0.50 , se observa que la empresa posee aún autonomía financiera, es decir es independiente frente a sus acreedores, por lo cual tiene control en la toma de decisiones para el desarrollo de la misma.

3.2.1.2 Índice mayor al 0.50 , se observa que la empresa no posee autonomía financiera, es decir depende de sus acreedores, a mayor porcentaje menos control tiene en la toma de decisiones para el desarrollo de la misma, se sugiere elegir correctamente las fuentes de financiamiento a largo plazo con menor inversión para así tomar el control de la empresa.

\subsubsection{Endeudamiento patrimonial}

3.2.2.1 Índice hasta el 0.50 mientras menor sea el resultado se observa que los acreedores son lo que financian mayormente a la empresa y muestra la cantidad de patrimonio necesario para la liquidación de las deudas a largo plazo.

3.2.2.2 Índice mayor al 0.50 mientras mayor sea el resultado se observa que el endeudamiento a largo plazo que posee la empresa proviene de cada dólar aportado por el propietario de la misma, y se verifica el porcentaje del patrimonio que sería necesario para la cancelación de deudas a largo plazo.

3.2.3 Endeudamiento del activo fijo

3.2.3.1 Índice menor a uno se observa que la totalidad del activo fijo que posee la empresa no proviene del financiamiento con el patrimonio de la misma, sino a las obligaciones con acreedores.

3.2.3.2 Índice igual o mayor a uno se observa que la totalidad del activo fijo que posee la empresa proviene del financiamiento con el patrimonio de la misma, sin acceder a obligaciones con acreedores. 


\subsubsection{Apalancamiento}

Se observa el grado de apoyo de los recursos que posee la empresa sobre los recursos provenientes de los acreedores. El beneficio es mayor si la rentabilidad del capital invertido es superior al costo de los capitales prestados. Se sugiere tomar en cuenta que si es una empresa con fuerte apalancamiento una reducción en el activo total puede absorber al patrimonio parcialmente, si existe un incremento permite revalorizar al patrimonio.

3.2.5 Apalancamiento financiero

3.2.5.1 Índice menor a uno se observa en la empresa que los fondos de terceros no contribuyen a la rentabilidad de los fondos propios, se sugiere verificar las tasas de interés de las deudas ya que cuando son más elevadas es complicado apalancarse financieramente.

3.2.5.2 Índice igual a uno se observa en la empresa que los fondos de terceros son indiferentes a la rentabilidad de los fondos propios, se sugiere verificar las tasas de interés de las deudas ya que cuando son más elevadas es complicado apalancarse financieramente.

3.2.5.3 Índice mayor a uno se observa en la empresa que los fondos de terceros contribuyen a la rentabilidad de los fondos propios, se sugiere verificar las tasas de interés de las deudas ya que cuando son más elevadas es complicado apalancarse financieramente.

\subsection{Factor de gestión}

\subsubsection{Rotación de cartera}

Se observa el número de veces que son recuperadas las cuentas por cobrar anuales generadas por las ventas a crédito, es decir cada dólar vendido se recupera y se vuelve a vender el número de veces resultante de la aplicación de la fórmula establecida.

\subsubsection{Rotación de activo fijo}

3.3.2.1 Índice menor a uno se observa en la empresa que existe insuficiencia eventual en ventas, ya que las ventas no se 
encuentran en proporción con el valor invertido en propiedad, planta y equipo.

3.3.2.2 Índice igual o mayor a uno se observa en la empresa que las ventas se encuentran en proporción con el valor invertido en propiedad, planta y equipo; lo que permitirá que no exista reducción en las utilidades al verse afectadas por la depreciación de un equipo excedente o costoso.

\subsubsection{Rotación de ventas}

3.3.3.1 Índice menor a uno se observa en la empresa que la relación de las ventas con el activo total no es el adecuado porque la recuperación de la inversión es baja a través de los ingresos; es decir, por cada dólar invertido no se recuperó un dólar en ventas, se sugiere asociar con los índices de utilidades de operación a ventas, utilidades a activo y el período medio de cobranza.

3.3.3.2 Índice igual o mayor a uno se observa en la empresa que la relación de las ventas con el activo total es el adecuado porque la recuperación de la inversión es la óptima a través de los ingresos; es decir, por cada dólar invertido se recuperó un dólar en ventas, se sugiere asociar con los índices de utilidades de operación a ventas, utilidades a activo y el período medio de cobranza.

\subsubsection{Periodo medio de cobranza}

Se observa el número de días que se tarda la empresa en cobrar las ventas realizadas a crédito, tomando en cuenta el tiempo que transcurre desde la venta hasta el cobro. Se sugiere tomar en cuenta solo las ventas a crédito y el periodo de cobro que se otorga a los clientes con lo cual si supera el periodo la recuperación no es eficiente.

\subsubsection{Periodo medio de pago}

Se observa el número de días que se tarda la empresa en pagar las deudas a corto plazo, tomando en cuenta el tiempo que transcurre desde la compra a crédito hasta la cancelación. Se sugiere no superar el periodo concedido en el crédito para conservar la reputación crediticia; si se cancela con anterioridad se debe tomar en cuenta que no afecte a 
la liquidez de la misma. Financieramente se debe cobrar antes y pagar después.

\subsubsection{Impacto gastos administración y ventas}

Se observa el impacto que producen los gastos administrativos y de ventas en la disminución de las utilidades netas y el margen operacional de la empresa. Se sugiere el análisis de este índice para aumentar la probabilidad de fortalecimiento del patrimonio y la distribución de utilidades que permiten el crecimiento de la misma.

\subsubsection{Impacto de la carga financiera}

3.3.7.1 Índice menor o igual al 0.10 se observa que en la empresa el impacto de la carga financiera no supera el 0.10 de las ventas lo que demuestra que los gastos financieros no tienen una mayor incidencia sobre los ingresos de la empresa. Se sugiere relacionar este indicador con el margen operacional.

Índice mayor al 0.10 se observa que en la empresa el impacto de la carga financiera supera el 0.10 de las ventas lo que demuestra que los gastos financieros tienen incidencia sobre los ingresos de la empresa. Se sugiere relacionar este indicador con el margen operacional y buscar alternativas para la disminución de los gastos financieros.

\subsection{Factor de rentabilidad}

\subsubsection{Rentabilidad neta del activo (dupont)}

Se observa que luego de multiplicar el margen neto de utilidad por la rotación de activos se obtiene la utilidad de la inversión total. Si el resultado obtenido es muy bajo se sugiere analizar los niveles de ventas, gastos, inventario y la administración de los activos fijos para verificar que no existe improductividad en los mismos.

\subsubsection{Margen bruto}

Se observa el rendimiento de las ventas con respecto al costo de ventas determinando además la capacidad de la empresa para cubrir los gastos operativos y obtener utilidades antes de deducciones e impuestos. Si el resultado obtenido es muy bajo se sugiere revisar el nivel de ventas de la empresa y los costos en los que incurre. 


\subsubsection{Margen operacional}

Se observa el resultado de los ingresos operacionales menos el costo de ventas, gastos de administración y gastos de ventas; es decir, si el negocio es o no lucrativo sin tomar en cuenta la forma como ha sido financiado. Si el resultado obtenido es muy bajo se sugiere revisar los gastos de administración y ventas.

\subsubsection{Rentabilidad neta de ventas (margen neto)}

Se observa la utilidad por cada unidad de venta. Este indicador se debe estudiar en conjunto con el de margen operacional. Si el resultado obtenido es muy bajo se sugiere analizar los niveles de ventas, gastos y así verificar que no existe improductividad en los mismos.

\subsubsection{Rentabilidad operacional del patrimonio}

Se observa la rentabilidad que la empresa ofrece a los socios o accionistas. Este indicador se debe estudiar en conjunto con el de rentabilidad financiera para conocer el impacto de los gastos financieros e impuestos en la utilidad. Si el resultado obtenido es muy bajo se sugiere analizar los niveles de ventas, gastos y así verificar que no existe improductividad en los mismos.

\subsubsection{Rentabilidad financiera}

Se observa el beneficio neto en relación a la inversión de los socios o accionistas, indicando los ingresos que dejan de percibir en las alternativas de inversiones de riesgo o costo de oportunidad. Si el resultado obtenido es muy bajo se sugiere analizar los niveles de ventas, gastos y así verificar que no existe improductividad en los mismos.

\section{Resultados}

A partir de la base de conocimiento del sistema experto de análisis financiero mediante el método vertical antes expuesta, se presenta en la Figura 8, los resultados generados para las empresas privadas televisivas nacionales: Teleamazonas y Ecuavisa.

La conclusión va enlazada con la numeración del punto 3 referente a la base de conocimiento del sistema experto. 
Figura 8. Indicadores Financieros de Teleamazonas y Ecuavisa

\begin{tabular}{|c|c|c|c|c|c|c|c|c|}
\hline Indicadores Técnicos & $\begin{array}{l}\text { Centrode } \\
\text { Radioy } \\
\text { Televisión } \\
\text { CratelC.A. }\end{array}$ & Ítem & $\begin{array}{l}\text { Teleamazonas- } \\
\text { Guayaquil S.A. }\end{array}$ & İtem & $\begin{array}{c}\text { Corporacion } \\
\text { Eauatoriana } \\
\text { de } \\
\text { Television } \\
\text { S.A. }\end{array}$ & Ítem & $\begin{array}{c}\text { Televisora } \\
\text { Nacional } \\
\text { Compania } \\
\text { Anónima } \\
\text { Telenacional } \\
\text { C.A. }\end{array}$ & Ítem \\
\hline \multicolumn{9}{|l|}{$\begin{array}{c}\text { FACTOR } \\
\text { LIQUIDEZ }\end{array}$} \\
\hline Liquidez Corriente & 1,6147 & 3.1.1.1 & 2,2168 & 3.1.1.2 & 2,7954 & 3.1.1.2 & 2,4906 & 3.1.1.2 \\
\hline Prueba Ácida & 1,1078 & 3.1.2.3 & 2,1308 & 3.1.2.3 & 1,7429 & 3.1.2.3 & 2,3287 & 3.1.2.3 \\
\hline \multicolumn{9}{|l|}{$\begin{array}{c}\text { FACTOR } \\
\text { SOLVENCIA }\end{array}$} \\
\hline $\begin{array}{l}\text { Endeudamiento } \\
\text { del Activo }\end{array}$ & 0,4622 & 3.2.1.1 & 0,3762 & 3.2.1.1 & 0,3793 & 3.2.1.1 & 0,4403 & 3.2.1.1 \\
\hline $\begin{array}{l}\text { Endeudamiento } \\
\text { Patrimonial }\end{array}$ & 0,8594 & 3.2.2.2 & 0,603 & 3.2.2.2 & 0,611 & 3.2.2.2 & 0,7868 & 3.2.2.2 \\
\hline $\begin{array}{l}\text { Endeudamiento } \\
\text { del Activo Fijo }\end{array}$ & 1,7031 & 3.2.3.2 & 0,9087 & 3.2.3.1 & 2,401 & 3.2.3.2 & 2,1413 & 3.2.3.2 \\
\hline Apalancamiento & 1,8594 & 3.2 .4 & 1,603 & 3.2 .4 & 1,611 & 3.2 .4 & 1,7868 & 3.2 .4 \\
\hline $\begin{array}{l}\text { Apalancamiento } \\
\text { Financiero }\end{array}$ & 1,8594 & 3.2 .5 .3 & 1,603 & 3.2.5.3 & 1,611 & 3.2.5.3 & 1,7868 & 3.2.5.3 \\
\hline \multicolumn{9}{|l|}{$\begin{array}{l}\text { FACTOR } \\
\text { GESTIÓN }\end{array}$} \\
\hline $\begin{array}{l}\text { Rotación de } \\
\text { Cartera }\end{array}$ & 3,2881 & 3.3 .1 & 5,7695 & 3.3 .1 & 2,7872 & 3.3 .1 & 3,6622 & 3.3 .1 \\
\hline $\begin{array}{l}\text { Rotación de } \\
\text { Activo Fijo }\end{array}$ & 3,7694 & 3.3.2.2 & 1,6215 & 3.3.2.2 & 2,4641 & 3.3.2.2 & 3,5631 & 3.3.2.2 \\
\hline $\begin{array}{l}\text { Rotación de } \\
\text { Ventas }\end{array}$ & 1,1903 & 3.3.3.2 & 1,1132 & 3.3.3.2 & 0,6371 & 3.3.3.1 & 0,9313 & 3.3.3.1 \\
\hline $\begin{array}{l}\text { Período Medio de } \\
\text { Cobranza }\end{array}$ & 111,007 & 3.3 .4 & 63,2642 & 3.3 .4 & 130,9539 & 3.3 .4 & 99,667 & 3.3 .4 \\
\hline $\begin{array}{l}\text { Período Medio de } \\
\text { Pago }\end{array}$ & 443,7957 & 3.3 .5 & 1181,1808 & 3.3 .5 & 275,1784 & 3.3 .5 & 2101,8337 & 3.3 .5 \\
\hline $\begin{array}{l}\text { Impacto Gastos } \\
\text { Administración y } \\
\text { Ventas }\end{array}$ & 0,3458 & 3.3 .6 & 0,405 & 3.3 .6 & 0,1846 & 3.3 .6 & 0,1703 & 3.3 .6 \\
\hline $\begin{array}{l}\text { Impacto de la } \\
\text { Carga Financiera }\end{array}$ & 0,1139 & 3.3.7.2 & 0 & 3.3.7.1 & 0,002 & 3.3.7.1 & 0 & 3.3.7.1 \\
\hline
\end{tabular}




\begin{tabular}{|c|c|c|c|c|c|c|c|c|}
\hline $\begin{array}{c}\text { FACTOR } \\
\text { RENTABILIDAD }\end{array}$ & & & & & & & & \\
\hline $\begin{array}{l}\text { Rentabilidad Neta } \\
\text { del Activo (Du } \\
\text { Pont) }\end{array}$ & $-0,1907$ & 3.4 .1 & $-0,0627$ & 3.4 .1 & $-0,0378$ & 3.4 .1 & $-0,001$ & 3.4 .1 \\
\hline Margen Bruto & 0,0331 & 3.4 .2 & 0,3743 & 3.4 .2 & 0,1216 & 3.4 .2 & 0,237 & 3.4 .2 \\
\hline $\begin{array}{l}\text { Margen } \\
\text { Operacional }\end{array}$ & $-0,1602$ & 3.4 .3 & $-0,0563$ & 3.4 .3 & $-0,0593$ & 3.4 .3 & $-0,0011$ & 3.4 .3 \\
\hline $\begin{array}{l}\text { Rentabilidad Neta } \\
\text { de Ventas (Margen } \\
\text { Neto) }\end{array}$ & $-0,1602$ & 3.4 .4 & $-0,0563$ & 3.4 .4 & $-0,0593$ & 3.4 .4 & $-0,0011$ & 3.4 .4 \\
\hline $\begin{array}{l}\text { Rentabilidad } \\
\text { Operacional del } \\
\text { Patrimonio }\end{array}$ & $-0,3546$ & 3.4 .5 & $-0,1004$ & 3.4 .5 & $-0,0609$ & 3.4 .5 & $-0,0018$ & 3.4 .5 \\
\hline $\begin{array}{l}\text { Rentabilidad } \\
\text { Financiera }\end{array}$ & $-0,3546$ & 3.4 .6 & $-0,1004$ & 3.4 .6 & $-0,0609$ & 3.4 .6 & $-0,0018$ & 3.4 .6 \\
\hline
\end{tabular}

Fuente: elaboración propia

\section{Conclusiones}

La aplicación de los índices del factor de liquidez en general en las empresas en análisis expone que la capacidad de las compañías para cubrir las obligaciones corrientes con los activos corrientes con y sin tomar en cuenta el inventario es la óptima, ya que por cada dólar de deuda posee un dólar con disponibilidad inmediata.

Los índices del factor de solvencia de cada una de las empresas en análisis tienen similitud, es así que se observa que las compañías poseen aún autonomía financiera, es decir son independientes frente a sus acreedores, por lo cual tienen control en la toma de decisiones para el desarrollo de la misma.

El factor de gestión a través de sus índices donde las observaciones son similares según la base de conocimiento del sistema experto para el total de las empresas en análisis, es así que las ventas se encuentran en proporción con el valor invertido en propiedad, planta y equipo; lo que permitirá que no exista reducción en las utilidades al verse afectadas por la depreciación de un equipo excedente o costoso,

Además se observa en las empresas que la relación de las ventas con el activo total es el adecuado porque la recuperación de la inversión es la 
óptima a través de los ingresos; es decir, por cada dólar invertido se recuperó un dólar en ventas, se sugiere asociar con los índices de utilidades de operación a ventas, utilidades a activo y el período medio de cobranza.

Para finalizar los índices del factor de rentabilidad indican que la rentabilidad de las compañías privadas televisivas nacionales en estudio es baja. Dado este caso se sugiere analizar los niveles de ventas, gastos, inventario y la administración de los activos fijos para verificar que no existe improductividad en los mismos.

\section{Referencias bibliográficas}

Arias Anaya RM (2012). Análisis e interpretación de los estados financieros. México: Edición Trillas.

Bonsón, E., Cortijo, V. \& Flores, F. (2009). Análisis de estados financieros. Fundamentos teóricos y casos prácticos. España: Pearson educación S.A.

Ecuavisa (2018). Recuperado el 12 de junio de 2018, de http://www.ecuavisa.com/tags/renovacion-frecuencia

One TV Year in the world. (2016). The overview of comumption and audiovisual landscapes in more tan 100 territories. Eurodata TV worldwide.

Superintendencia de Compañías, Valores y Seguros, (2016). Notas Explicativas a los Estados Financieros por el año terminado el 31 de diciembre del 2016. Recuperado el 12 de junio de 2018, de http://appscvs.supercias.gob.ec/consultaImagen/VisualizaD ocumetos.zul?tipoDocumento $=$ economica\&expediente $=482$ 58\&idDocumento $=3.1 . \mathrm{L} \% 20 \% 20 \&$ fecha $=2016-12$ 31\%2017:17:40.0

Superintendencia de Compañías, Valores y Seguros, (2016). Notas Explicativas a los Estados Financieros por el año terminado el 31 de diciembre del 2016. Recuperado el 12 de junio de 2018, de http://appscvs.supercias.gob.ec/consultaImagen/VisualizaD ocumetos.zul?tipoDocumento $=$ economica\&expediente $=460$ 
13\&idDocumento $=3.1 . \mathrm{L} \% 20 \% 20 \&$ fecha $=2016-12-$

31\%2000:00:00.0

Superintendencia de Compañías, Valores y Seguros, (2016). Notas

Explicativas a los Estados Financieros por el año terminado el 31 de diciembre del 2016. Recuperado el 12 de junio de 2018, de http://appscvs.supercias.gob.ec/consultaImagen/VisualizaD ocumetos.zul?tipoDocumento $=$ economica\&expediente $=441$ 9\&idDocumento $=3.1 . \mathrm{L} \% 20 \% 20 \&$ fecha $=2016-12$ 31\%2000:00:00.0

Superintendencia de Compañías, Valores y Seguros, (2016). Notas Explicativas a los Estados Financieros por el año terminado el 31 de diciembre del 2016. Recuperado el 12 de junio de 2018, de http://appscvs.supercias.gob.ec/consultaImagen/VisualizaD ocumetos.zul?tipoDocumento $=$ economica\&expediente $=105$ 60\&idDocumento $=3.1 . \mathrm{L} \% 20 \% 20 \&$ fecha $=2016-12$ 31\%2000:00:00.0

Superintendencias de Compañías, Valores y Seguros, (2008). Indicadores financieros. Recuperado el 12 de junio de 2018, de http://www.supercias.gob.ec/visorPDF.php?url=bd superci as/descargas/ss/20111028102451.pdf 



\section{4 \\ Las autoras y los autores}

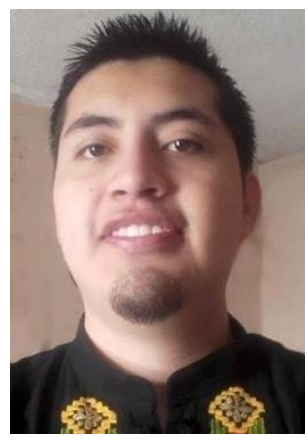

\section{ARAGÓN-PUETATE, JOHNNY ALEJANDRO}

Pontificia Universidad Católica del Ecuador Sede Ibarra

ja.aragon@hotmail.com

Ingeniero en Sistemas egresado de la Pontificia Universidad Católica del Ecuador Sede Ibarra.

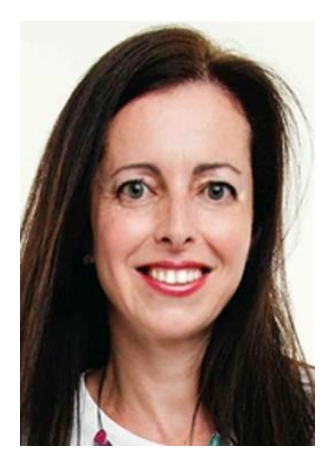

BENÍTEZ DE GRACIA, MARÍA JOSÉ

\section{Universidad Carlos III de Madrid}

majbenitez@gmail.com

Licenciada en Periodismo (Universidad Europea de Madrid, 2000) y Máster en Investigación Aplicada a los Medios de Comunicación por la Universidad Carlos III de Madrid (2016), donde realiza actualmente el doctorado sobre el reportaje inmersivo en vídeo en $360^{\circ}$, bajo la dirección de la doctora Susana Herrera. Forma parte del grupo de investigación Innovation on Digital Media, dirigido por la profesora Susana Herrera, en la Universidad Carlos III de Madrid.

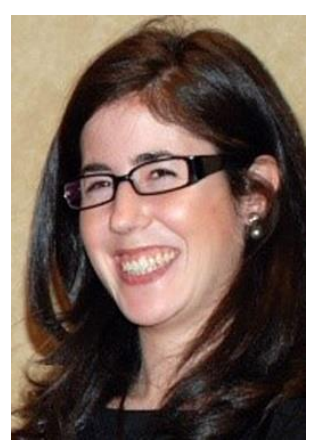

\section{CABALLERO TRENADO, LAURA}

\section{Universidad Internacional de La Rioja}

laucab01@ucm.es

Asesora jurídica y docente con más de diez años de experiencia en gestión y enseñanza presencial y online. Especialista en Derecho Civil y Mercantil, Tecnológico y Entertainment Law, actualmente es profesora de Gestión y comercialización de los derechos de Propiedad Intelectual en el Master en Propiedad Intelectual en UNIR. 


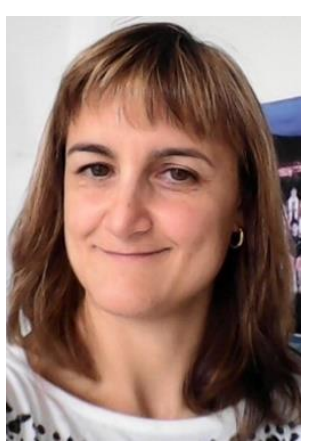

\section{CAMACHO, IDOIA}

\section{Universidad del País Vasco}

idoia.camacho@ehu.eus

Profesora Agregada de la Facultad de Ciencias Sociales y Comunicación de la Universidad del País Vasco. En la actualidad es Vicedecana de Comunicación y Relaciones Externas de la Facultad de Ciencias Sociales de dicha Facultad. Es autora del libro Formación de portavoces: Cómo conseguir una comunicación efectiva ante los medios y otros públicos.

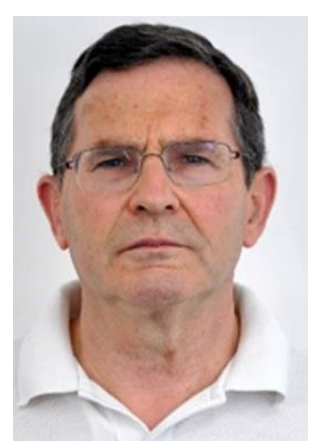

\section{CAMPOS-FREIRE, FRANCISCO}

\section{Universidade de Santiago de Compostela}

francisco.campos.freire@gmail.com

Profesor de Periodismo de la Facultad de Ciencias de la Comunicación de la Universidad de Santiago de Compostela desde 1991, función que alterna con la actividad periodística y gestora en la dirección del diario La Región de Ourense, la Agencia Gallega de Noticias, la Compañía de Radio y Televisión de Galicia y la presidencia de FORTA. Desde 2005 está exclusivamente dedicado a labor docente e investigadora en la Universidad de Santiago de Compostela, que compagina con estancias en otras Universidades y proyectos, entre ellos el Programa Prometeo de investigación de Ecuador (2014-16). Es miembro del Grupo de Investigación de Novos Medios de la USC y co-IP de las Redes XESCOM e INNONEWS.

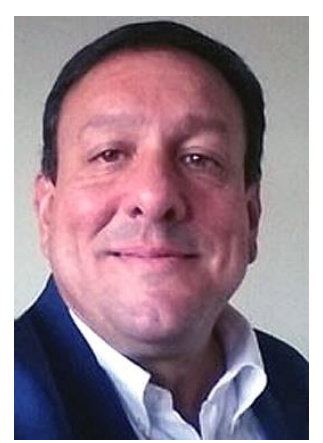

\section{GALINDO ARRANZ, FERMÍN}

\section{Universidade de Santiago de Compostela}

fermin.galindo@usc.es

Fermín Galindo es Doctor en Ciencias de la Información por la Universidad del País Vasco (1992) y Profesor Titular de Periodismo de la Universidad de 
Santiago de Compostela. Universidad en la que participa de forma estable en el Master en Marketing y Comunicación Política de la Facultad de Ciencias Políticas y de la Administración de la USC. Ha publicado numerosos libros y trabajos sobre el tema, entre ellos: Fundamentos de Comunicación Política (1998), A Comunicación Política Hoxe (1999), Ámbitos del Periodismo de Precisión (2004) y Las notas de la prensa (2010) y Siete Picas. Entre la Ciencia y el Periodismo (2016). En la actualidad imparte las materias Métodos de Investigación en Comunicación y Géneros Interpretativos y de Opinión.

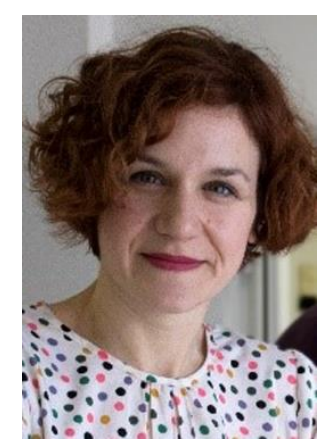

\section{GALLETERO CAMPOS, BELÉN}

\section{Universidad de Castilla-La Mancha}

Belen.Galletero@uclm.es

Belén Galletero-Campos es licenciada en Periodismo por la Universidad de Navarra, experta en Guion para televisión y Cine por la Universidad Pontificia de Salamanca, máster en Comunicación Política y Empresarial por la Universidad Camilo José Cela, y doctora por la Universidad de CastillaLa Mancha (UCLM). Ha trabajado como periodista durante una década y actualmente es Profesora Ayudante en la Facultad de Periodismo de la UCLM.

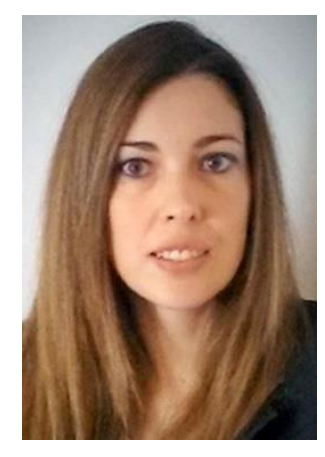

\section{LÓPEZ CEPEDA, ANA MARÍA}

\section{Universidad de Castilla-La Mancha}

ana.lopezcepeda@uclm.es

Licenciada en Periodismo por la Universidad de Santiago de Compostela (USC), Licenciada en Derecho por la Universidad Nacional de Educación a Distancia (UNED) y Doctora en Comunicación y Periodismo por la Universidad de Santiago de Compostela (USC). En la actualidad es Profesora Contratada Doctora en la Facultad de Periodismo de la Universidad de Castilla-La Mancha (UCLM), en donde también ejerce como Vicedecana desde 2017. 


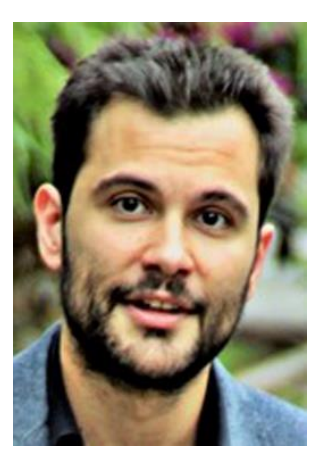

\section{LÓPEZ-LÓPEZ, PAULO CARLOS}

Pontificia Universidad Católica del Ecuador Sede Ibarra

pclopez@pucesi.edu.ec

Doctor en Comunicación e Industrias Creativas por la Universidad de Santiago de Compostela y docenteinvestigador en la Carrera de Comunicación en la Pontificia Universidad Católica del Ecuador Sede Ibarra (Ecuador). Posee el Diploma de Estudios Avanzados en el Programa de Doctorado Comunicación y Periodismo de la USC. Licenciado en Periodismo en la rama de periodismo electrónico y Licenciado en Ciencias Políticas y de la Administración en la rama de Relaciones Internacionales por la misma Universidad.

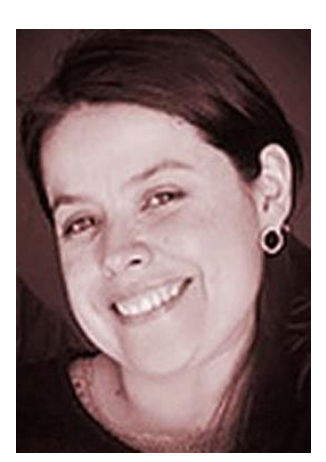

\section{MIER-SANMARTÍN, CATALINA}

\section{Universidad Técnica Particular de Loja}

cmier@utpl.edu.ec

Doctora en Comunicación y Periodismo en la Universidad Santiago de Compostela-España y Licenciada en Comunicación Social en la Universidad de Cuenca (Ecuador), Catalina es Docente-Investigadora en la Sección de Narrativas Audiovisuales en el Departamento de Ciencias de la Comunicación de la Universidad Técnica Particular de Loja.

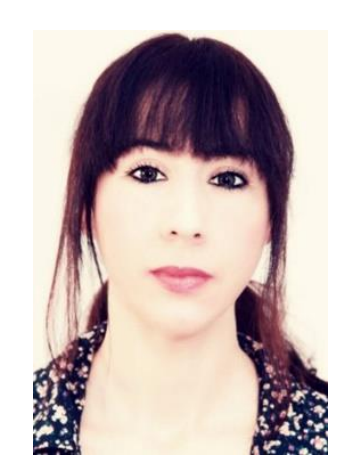

\section{MONEDERO MORALES, CARMEN DEL ROCÍO}

\section{Universidad de Málaga}

roi@uma.es

Doctora con Mención Europea en Periodismo por la Universidad de Málaga, en la actualidad ejerce como docente en el Departamento de Periodismo endicha institución. Su línea de investigación está focalizada en el campo de la televisión de proximidad y en la televisión digital en el contexto español, europeo y latinoamericano. También forma parte de equipos 
investigadores centrados en los medios y la educación o en comunicación y género y en periodismo cultural.

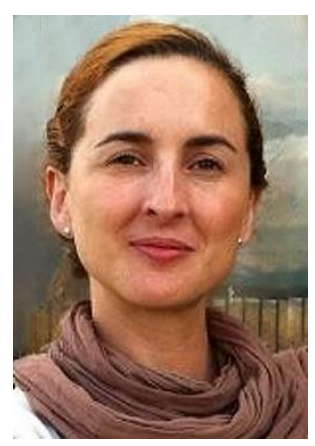

\section{OLMEDO SALAR, SILVIA}

\section{Universidad de Málaga}

silviaolmedo@uma.es

Doctora y Licenciada en Periodismo por la Universidad de Málaga y Máster en Gestión Estratégica e Innovación en Comunicación por la misma universidad. Actualmente es profesora Ayudante

Doctora del Departamento de Periodismo de la Universidad de Málaga. Su línea de investigación se ha centrado en torno a la democratización mediática, la radio local y la comunicación en el ámbito de la cooperación internacional.

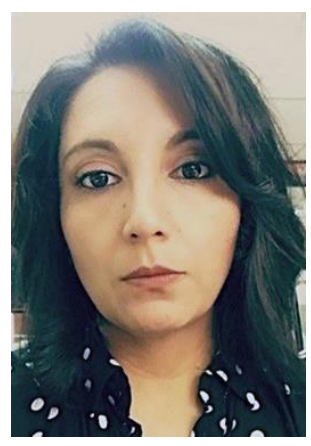

\section{ORDÓÑEZ GONZÁLEZ, KRUZKAYA}

\section{Universidad Técnica Particular de Loja}

keordonez@gmail.com

Máster en Comunicación e Industrias Creativas. Doctoranda de la Universidad Santiago de Compostela-España. Docente anexa al Departamento de Ciencias de la Comunicación Universidad Técnica Particular de Loja, sección departamental Narrativas Audiovisuales. Líneas de investigación televisión local, medios audiovisuales, comunicación digital, divulgación científica. Miembro del comité de Periodismo educativo del Ecuador. Directora y productora de documentales de investigación científica. Participación en la Red de Narrativas Audiovisuales y Red Temática de Aplicaciones y Usabilidad de Televisión Interactiva en América Latina REDAUTI. Participación en Proyectos con financiación institucional y externa. 


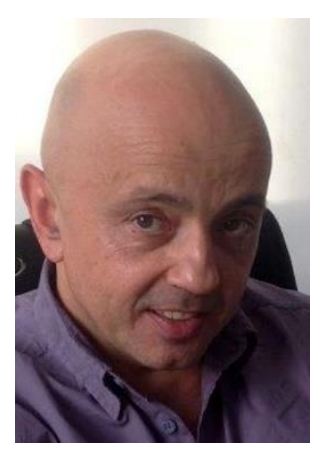

\section{PASTOR, JOSE MARI}

\section{Universidad del País Vasco}

josemari.pastor@ehu.eus

Profesor de la Facultad de Ciencias Sociales y Comunicación de la Universidad del País Vasco. Sus áreas de investigación se centran en la televisión y en los medios de comunicación en línea.

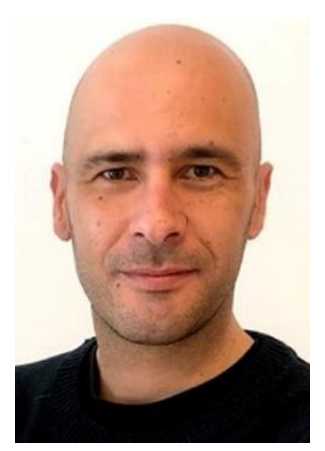

PÉREZ SÁNCHEZ, JAVIER

\section{Universidad Europea de Madrid}

javier.perez@universidadeuropea.com

Doctor en Comunicación por la Universidad Europea, Licenciado en Comunicación Audiovisual, y Certificado de Aptitud Pedagógica por la Universidad de Alcalá de Henares. En el ámbito profesional en los medios de comunicación ha ejercido como Realizador de Deportes (Digital+), Realizador de promociones (Antena 3 y Fox International Channels), director de deportes (Teletoledo y La Regional CLM), CEO de la productora Grupo Visual E. Producciones (especializada en contenidos informativos deportivos, programas y autopromoción a nivel autonómico).

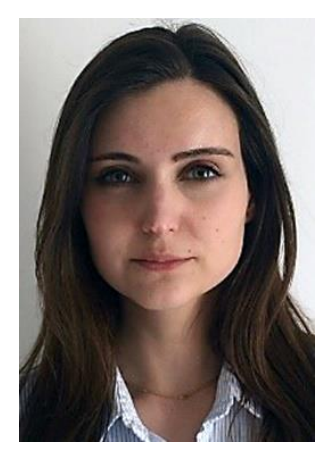

\section{PÉREZ-SEIJO, SARA}

\section{Universidade de Santiago de Compostela}

s.perez.seijo@usc.es

Investigadora del grupo Novos Medios y doctoranda en Comunicación e Información Contemporánea en la Universidade de Santiago de Compostela (USC). Actualmente es beneficiaria del programa de Formación del Profesorado Universitario (FPU16/06156) financiado por el Ministerio de Educación, Cultura y Deporte (Gobierno de España). 


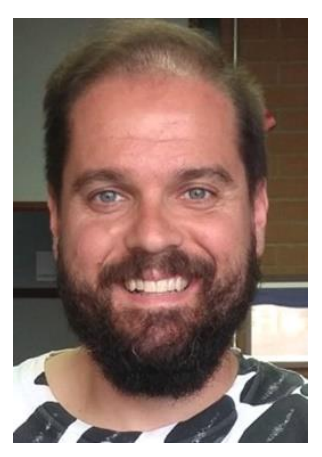

\section{PUENTES-RIVERA, IVÁN}

\section{Universidade de Santiago de Compostela}

ivan.puentes@usc.es

Doctor en Comunicación, Licenciado en Publicidad y Relaciones Públicas y Máster en Investigación en Comunicación, es profesor en la Facultad de Ciencias de la Comunicación de la Universidad de Santiago de Compostela, además de profesor invitado y miembro del grupo CP2: Comunicación Persuasiva de la Universidad de Vigo, vinculado a la Red Internacional de Investigación de la Gestión de la Comunicación (XESCOM).

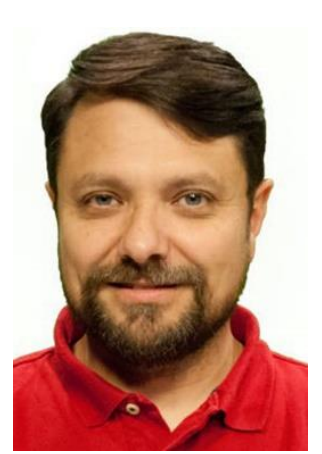

\section{REGUEIRA REY, JUAN CARLOS}

Universidade de Santiago de Compostela

carlos.regueira@gmail.com

Carlos Regueira (Vigo, 1965) trabaja como productor audiovisual desde 1988 en la Televisión de Galicia. Licenciado en Comunicación Audiovisual por la Uvigo (2007), su etapa investigadora comienza con la coautoría del primer trabajo de investigación financiado por la AGADIC (Axencia Galega das Industrias Musicais) sobre las orquestas de verbena de Galicia. Como docente, ha sido profesor asociado de la USC y co-director del primer Master en Industria Musical de la USC. Su línea de investigación se sitúa en la intersección entre los media studies y la música popular, eje de la tesis que escribe en la actualidad.

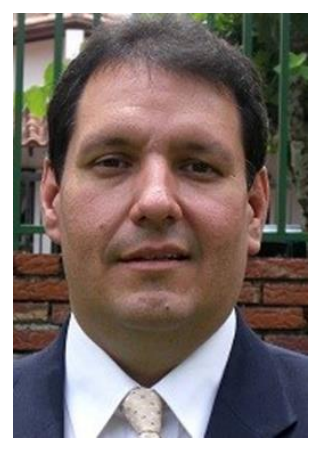

\section{RIVAS-ECHEVERRÍA, FRANCKLIN IVÁN}

Universidad Técnica Federico Santa María

Pontificia Universidad Católica del Ecuador Sede Ibarra

frivas6@gmail.com

Ingeniero en Sistemas egresado de la Escuela de Ingeniería de Sistemas de la Universidad de Los Andes. Magíster en Ingeniería de Control. Doctor en Ciencias Aplicadas. Mérida - 
Venezuela. Académico de la Universidad Técnica Federico Santa María, Chile. Profesor Titular Jubilado de la Escuela de Ingeniería de la Universidad de Los Andes, Venezuela. Docente de la Escuela de Ingeniería de la Pontificia Universidad Católica del Ecuador Sede Ibarra.

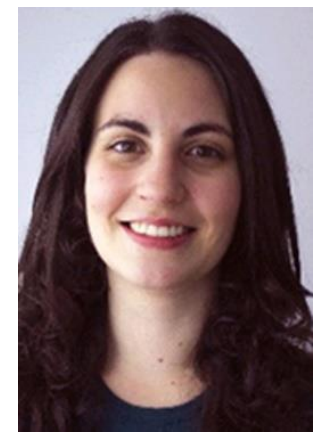

\section{RODRÍGUEZ-CASTRO, MARTA}

\section{Universidade de Santiago de Compostela}

m.rodriguez.castro@usc.es

Graduada en Comunicación Audiovisual por la Universidad de Santiago de Compostela (USC) y máster en Investigación aplicada a medios de comunicación por la Universidad Carlos III de Madrid. Actualmente es doctoranda en Comunicación e información contemporánea en la USC, donde es contratada FPU (FPU16/05234) e investigadora del grupo Novos Medios. Ha sido Visiting Fellow en el Center for Media, Data and Society de la Central European Univeristy en Budapest.

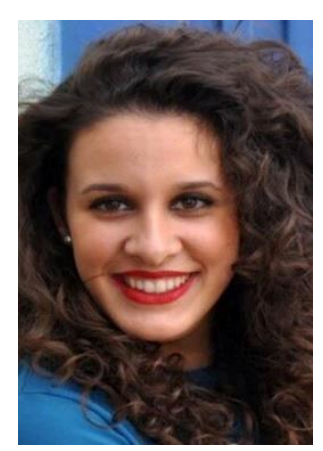

\section{TERUEL CARRIÓN, INMACULADA}

\section{Universidad de Castilla-La Mancha}

inma.alpera@hotmail.com

Inma Teruel Carrión es graduada en Periodismo por la Universidad de Castilla-La Mancha, con un máster en Periodismo Deportivo por la Universidad de Sevilla. Ha trabajado como community manager y ha realizado prácticas en la televisión provincial de Albacete, V6 y en la Televisión del Sevilla FC. Ha sido Jefa de Prensa de la Fundación Albacete Femenino durante la Temporada 2017-2018. 


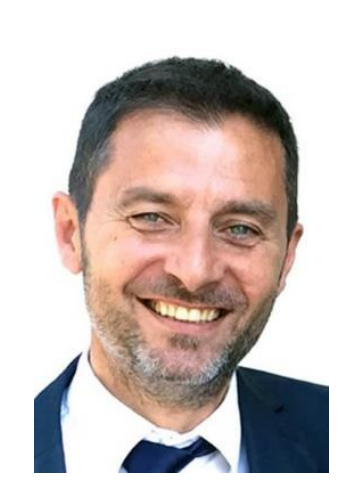

\section{TÚÑEZ-LÓPEZ, MIGUEL}

Universidade de Santiago de Compostela

miguel.tunez@usc.es

Doctor en Periodismo por la Universidad Autónoma de Barcelona y Profesor de Comunicación

Organizacional y Estrategias de Comunicación en la Universidade de Santiago de Compostela. Consultor.

Miembro del Grupo de Investigación Novos Medios. Premio

Nacional de Periodismo Reina Sofía.

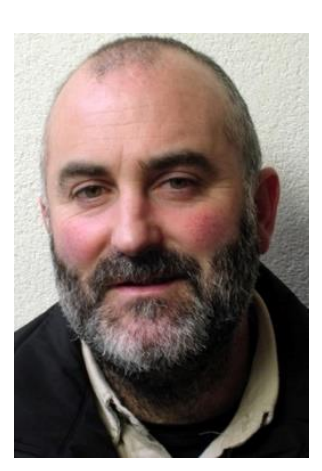

\section{URRUTIA, SANTI}

\section{Universidad del País Vasco}

santi.urrutia@ehu.eus

Profesor agregado de la Facultad de Ciencias Sociales y Comunicación de la Universidad del País Vasco y Secretario de la Comisión Académica del Máster de Comunicación Multimedia UPV/EHU-EITB. Sus principales líneas de investigación son Medios de comunicación y periodismo en lenguas minoritarias europeas y Ética de los medios y prácticas de los usuarios de redes sociales.

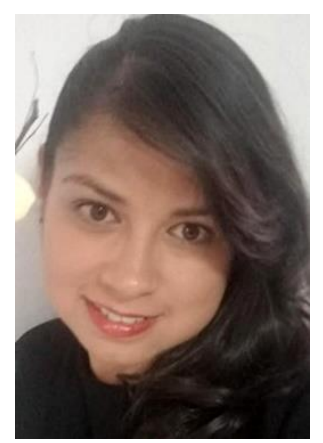

\section{VACA-TAPIA, ANA CECILIA}

Pontificia Universidad Católica del Ecuador Sede Ibarra

\section{Universidade de Santiago de Compostela}

ana.c.vaca.tapia@gmail.com

Licenciada Contadora Pública Autorizada de la Pontificia Universidad Católica del Ecuador Sede Ibarra. Máster en Comunicación e Industrias Creativas y Doctorando en Comunicación e Información Contemporánea en la Universidad Santiago de Compostela - España. Docente de la Pontificia Universidad Católica del Ecuador Sede Ibarra. 


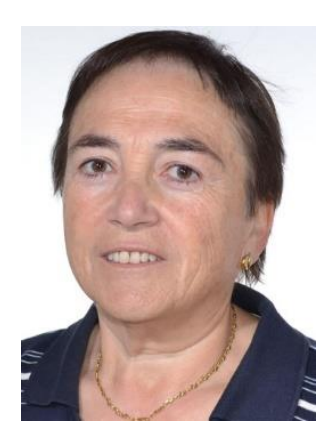

\section{ZALBIDEA, BEGOÑA}

\section{Universidad del País Vasco}

bego.zalbidea@ehu.eus

Profesora Titular de la Facultad de Ciencias Sociales y de la Comunicación de la Universidad del País Vasco, e Investigadora Principal de varios proyectos del MICINN y MINECO, y del Grupo Consolidado UPV/EHU "Ética e Información". El proyecto ministerial actualmente vigente lleva por título: Reacciones desde la ética ciudadana en la red social Menéame. 